\title{
3. SITE 443, SHIKOKU BASIN, DEEP SEA DRILLING PROJECT LEG 58
}

\author{
Shipboard Scientific Party ${ }^{1}$
}

\section{HOLE 443}

Date occupied: December 28, 1977

Date departed: January 4, 1978

Time on hole: 6 days

Position (latitude; longitude): $29^{\circ} 19.65^{\prime} \mathrm{N} ; 137^{\circ} 26.43^{\prime} \mathrm{E}$

Water depth (sea level; corrected m, echo-sounding): 4372.0

Water depth (rig floor; corrected $\mathrm{m}$, echo-sounding): 4386.0

Bottom felt (m, drill pipe): 4386.0

Penetration (m): 581.5

Number of cores: 64

Total length of cored section $(\mathrm{m}): 581.5$

Total core recovered $(\mathrm{m}): 304.5$

Core recovery $(\%): 52$

Oldest sediment cored:

Depth sub-bottom $(\mathrm{m}): 475.0$

Nature: mudstone

Age: early middle Miocene ( 15 m.y.)

Measured velocity $(\mathrm{km} / \mathrm{s}): 1.56$

Basement:

Depth sub-bottom (m): 581.5

Nature: basalt

Velocity range $(\mathrm{km} / \mathrm{s}): 3.82-5.82$

Principal Results: Site 443 is in the east-central part of the Shikoku Basin. The stratigraphic section consists of 44 meters

\footnotetext{
${ }^{1}$ George deVries Klein (Co-Chief Scientist), Department of Geology, University of Illinois, Urbana, Illinois; Kazuo Kobayshi (CoChief Scientist) Ocean Research Institute, University of Tokyo; Stan M. White, Deep Sea Drilling Project, Scripps Institution of Oceanography, La Jolla, California; Hervé Chamley, Laboratoire de Géologie Marine, Centre d'Océanographie, Centre Universitaire de Luminy, Marseille, France (now at Université de Lille I, Villaneuve d'Ascq, France); Doris Curtis, Bellaire Research Center, Shell Development Company, Houston, Texas; Atsuyuki Mizuno, Geological Survey of Japan, Kawasaki, Japan; Henry Dick, Department of Geology and Geophysics, Woods Hole Oceanographic Institution, Woods Hole, Massachusetts; Gennady V. Nisterenko, Vernadasky Institute of Geochemistry and Analytical Chemistry, USSR Academy of Sciences, Moscow, USSR; Nicholas G. Marsh, Department of Geological Sciences, University of Birmingham, Birmingham, England; Douglas Waples, Chemistry and Geochemistry Department, Colorado School of Mines, Golden, Colorado; Dorothy Jung Echols, Department of Earth and Planetary Sciences, Washington University, St. Louis, Missouri; Hisatake Okada, Department of Geology, Faculty of Science, Yamagata University, Yamagata, Japan; Jon R. Sloan, Department of Geology, University of California, Davis, California; David M. Fountain, Department of Geology, University of Montana, Missoula, Montana; and Hajimu Kinoshita, Department of Earth Sciences, Faculty of Science, Chiba University, Tokyo, Japan.
}

of Pleistocene mud; 77 meters of Pleistocene nannofossil clay, clayey nannofossil ooze, and ash; 57 meters of Pliocene ash and clay; 24 meters of Pliocene mud; 57 meters of Miocene mud and nanno ooze; 31 meters of Miocene mudstone; 45 meters of Miocene nannofossil chalk and mudstone; 98 meters of Miocene claystone, mudstone, ash and chalk; 35 meters of phyric-olivine-basalt flow, with hydrothermal veins; 34 meters of pillow-lava flows; and 47 meters of interbedded phyric-basalt flows and pillow-lava flows. Continuous sedimentation started with middle Miocene resedimentation of volcaniclastic, hemipelagic, and pelagic sediments and was then dominated by post-middle-Miocene hemipelagic sedimentation slightly above the CCD. The age of the oldest sediment is $15 \mathrm{~m} . \mathrm{y}$. , providing a basement age at variance with the magnetic-anomaly age. Magnetic inclination of basalts shows a combination of reversed polarity and normal polarity, with both high and low inclinations.

\section{BACKGROUND AND OBJECTIVES}

\section{Background}

The background and objectives for Site 443 are directly related to and coordinated with the background and objectives reviewed for Site 442 .

Site 443 is in the Shikoku Basin, which provides a unique testing ground for the rifting model of the origin of marginal basins. The marine geology of the Shikoku Basin was summarized by Karig, Ingle, et al. (1975); Tomoda et al. (1975); Kobayashi and Isezaki (1976); and Watts and Weissel (1975). The magnetic-anomaly pattern of the Shikoku Basin is linear (Tomoda et al., 1975), and age determinations of these patterns by Kobayashi and Isezaki (1976), Watts and Weissel (1975), and Kobayashi and Nakata (1977) suggested a symmetrical-spreading history for the Shikoku Basin. Spreading originated from a now-extinct spreading center about $28 \mathrm{Ma}$ and ceased at about $18 \mathrm{Ma}$.

Basement age determination was attempted (Karig, Ingle, et al., 1975) during Leg 31 of the Deep Sea Drilling Project when Site 297 was drilled; however, drilling there failed to reach basement. Drilling at Site 442 permitted determination of basement age, (18-21 m.y.), which is in agreement with location of that site on magnetic anomaly 6 (see Site 442 report, this volume). Drilling results at Site 442 demonstrated that during the earlier history of rifting pelagic carbonates and zeolitic clays were deposited, but later and also during the period following spreading deposition of hemipelagic clay was dominant. These hemipelagic clays were part of the distal zone of a large clastic wedge which thickens westward towards the Kyushu-Palau Ridge. The dom- 
inance of hemipelagic sediments at Site 442 is at variance with the occurrence of turbidites, thick ashes, and clayey nannofossil oozes at Site 297.

The nature of the crust underlying marginal basins has been of interest. Several investigators demonstrated that marginal basins are underlain by oceanic crust (Fischer, Heezen, et al., 1971; Andrews, Packham, et al., 1975; Ridley et al., 1974). Drilling at Site 442 demonstrated that the Shikoku Basin is underlain also by oceanic basalts, but these basalts are characterized by a higher-than-normal vesicularity, and they lack olivine.

Site 443 was positioned on a moderate positive magnetic anomaly, identified as anomaly $6 \mathrm{~A}$, on the eastern side of a hypothetical extinct spreading center in the Shikoku Basin. This site was located along a seismicreflection profile surveyed by the R/S Kaiyo-Maru (IPOD, Japan, 1977), shown in Figure 1. The seismic survey line obtained by the D/V Glomar Challenger is shown in Figure 2. The survey track is shown in Figure 3.

\section{Objectives}

The primary drilling objectives at Site 443 were threefold. Of prime importance was the determination, from paleontological study, of the age of the basaltic basement, so as to calibrate the magnetic-anomaly age determination of previous studies and thus test the proposed symmetrical-spreading origin of the Shikoku Basin.

A second objective was the determination of the mineralogy, petrology, and chemical composition of the basaltic floor of the Shikoku back-arc basin and comparison of these findings with new findings at Site 442 concerning composition, vesicularity, and olivine content. These data are also to be compared to oceaniccrust data from other settings. In addition, the paleomagnetic ages of the basaltic columnar section were to be determined to understand the crustal evolution of this and other back-arc basins.

A third objective deals with the nature of sediment dispersal into the Shikoku Basin. Prior drilling at Sites
297 and 442 indicated derivation of sediment from Shikoku Island and the Kyushu-Palau Ridge. Do the sediments at Site 443 represent supply from a third source or from one or both of the sources known to date? Finally, because Site 443 is near a southerly meandering portion of the Kuroshio Current, is there evidence of higher biogenic productivity at this site, as suggested, for instance, at Site 297 by Karig, Ingle, et al. (1975)?

\section{OPERATIONS}

The Glomar Challenger departed Site 442 for Site 443 at 2242 hours, 27 December 1977. Upon departure, a sonobuoy was run; then a course of $072^{\circ}$ was followed to the Site 443 area, approximately 72 nautical miles to the northeast (Figure 3).

At 1000 hours, 28 December, a $13.5-\mathrm{kHz}$ beacon was dropped. Following a Williamson turn, the ship returned to the site of the beacon drop and began positioning procedures. PDR water depth to drill floor was calculated as 4382 meters. At 1241 hours, positioning over the beacon was achieved, and at 1300 hours the bottom-hole assembly was made up and running in hole began.

Probing for bottom began at 2130 hours, spudding and run-in to take first core occurring at 2200 hours. The first core, recovering 6.86 meters of sediment, was on deck at 2258 hours (Table 1).

Basalt was first recovered in Core 49 at approximately 460 meters sub-bottom depth (Table 1). Coring continued through Core 63, uneventful except for a 1-hour wait on weather following retrieval of Core 55. High winds at this time caused a 200 -foot excursion of the ship from the beacon.

Following retrieval of Core 63, high winds (gusts to $40 \mathrm{mph}$ ), along with sea conditions causing pitches up to $7^{\circ}$, forced termination of drilling at Site 443 at 0715 hours, 3 January 1978. Accordingly, operations to pull out of the hole began. The bit reached the mudline at 0900 hours, and at that time Core 64 , the last core taken before termination, was retrieved. It was cored from

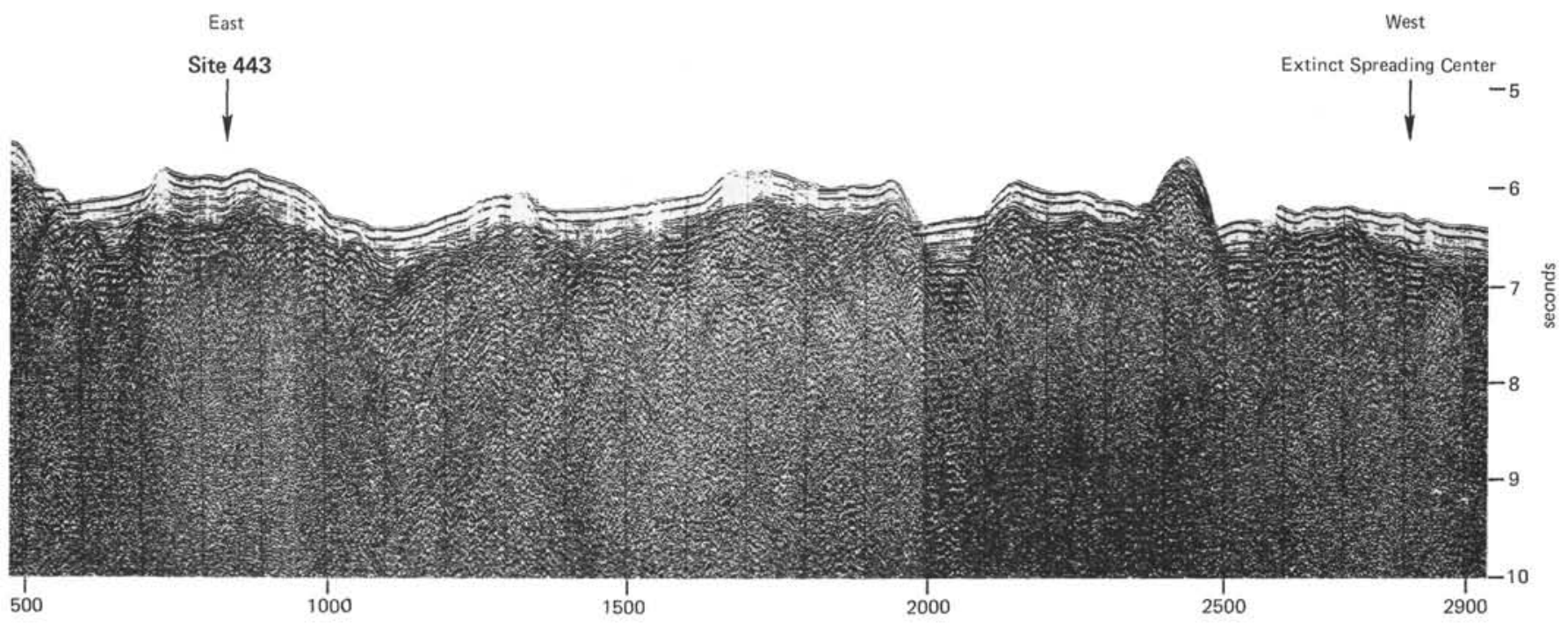

Figure 1. Seismic-survey line through Shikoku Basin by $R / V$ Kaiyo Maru. 


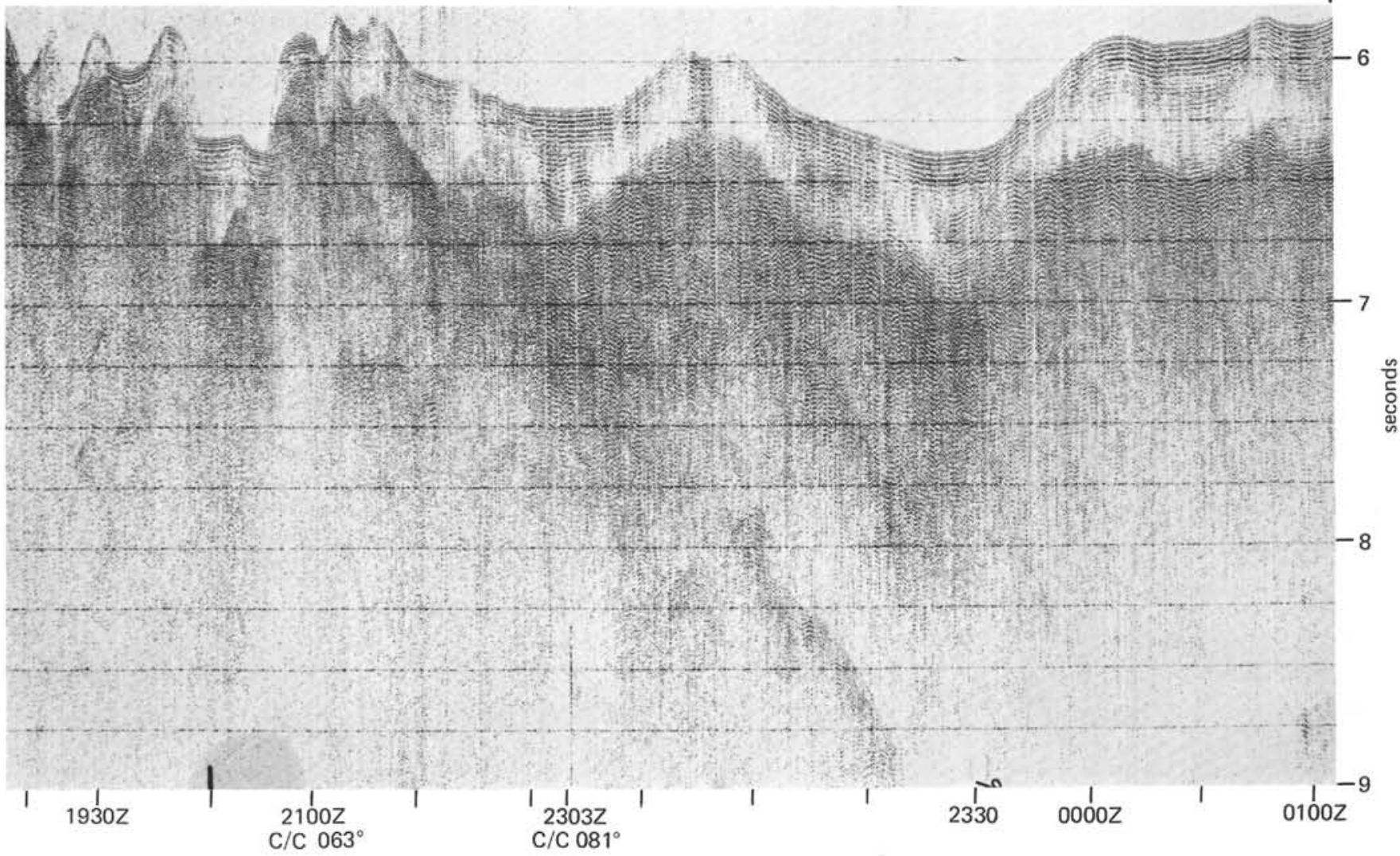

Figure 2. Glomar Challenger seismic-reflection profile approaching Site 443. See Figure 3 for location.

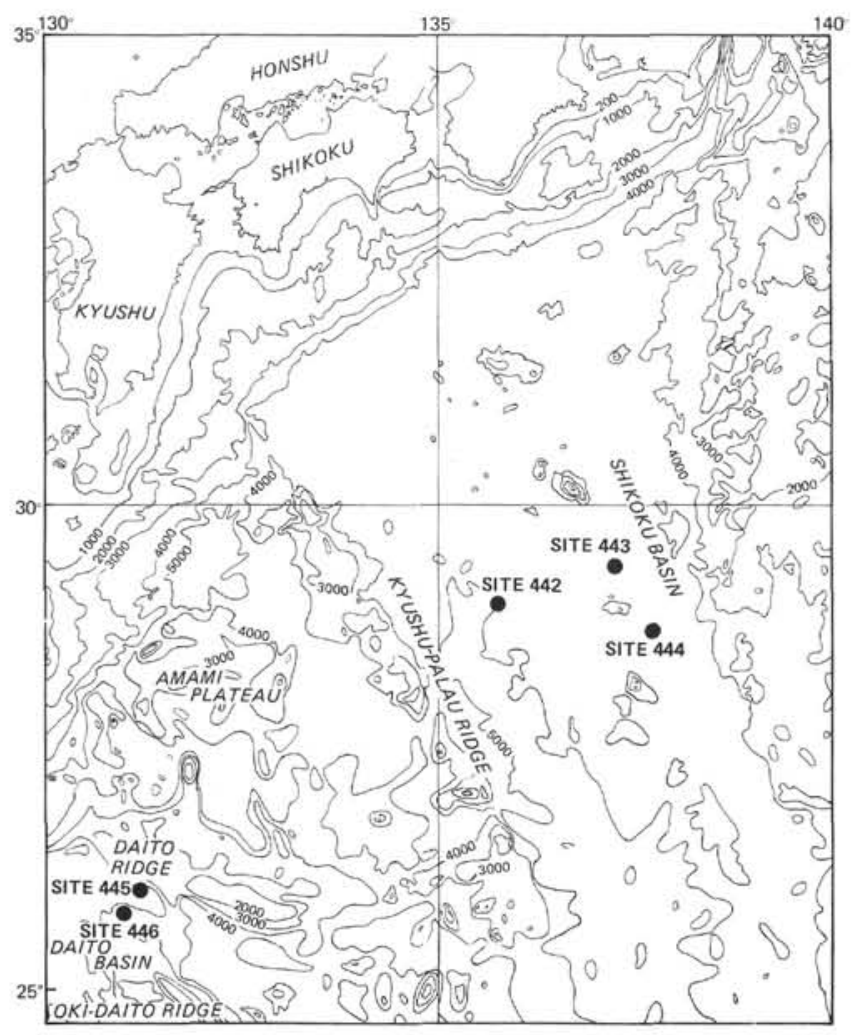

Figure 3. Site location map.
577.0-581.5 meters sub-bottom depth. Bit life at this site was 50.2 hours, 45.5 hours in basalt.

At 0018 hours, 4 January 1978, the bit was on the drill floor, and at 0042 hours preparations were made to head for Site 444.

\section{SEDIMENT LITHOLOGY}

A single-bit hole was drilled at Site 443 . The drill string penetrated 581.5 meters, of which 457 meters were sediment. Forty-nine sediment cores were recovered, ranging in age from early middle Miocene (about 15 m.y.) to late Quaternary.

Five lithologic units were recognized, according to color of the fresh sediment, the nature of the dominant paleontological and mineralogical components, and sedimentary structures. Table 2 and Figure 4 summarize the stratigraphy for Site 443; Table 3 summarizes the color and main smear-slide data.

\section{Unit I}

Unit I is present in Cores 433-I through 443-13. It is 121 meters thick and consists of dominantly darkgreenish-gray (5GY4/1), soft to firm mud, without noticeable sedimentary structure. The nature of the main sedimentary components allows further subdivision into two sub-units. Sub-unit Ia (Cores 1 to 5-CC, 0 to $44.8 \mathrm{~m}$ ) is a mud with ash interbeds or streaks. The silt-sized fraction constitutes about 20 per cent of the 
TABLE 1

Site 443 Coring Summary

\begin{tabular}{|c|c|c|c|c|c|c|c|}
\hline Cortes & $\begin{array}{c}\text { Date } \\
\text { (Dec., 1977 } \\
\text { and } \\
\text { Jan., 1978) }\end{array}$ & Time & $\begin{array}{l}\text { Depth From } \\
\text { Drill Floor } \\
\text { (m) } \\
\text { Top Bottom }\end{array}$ & $\begin{array}{l}\text { Depth Below } \\
\text { Sea Floor } \\
\text { (m) } \\
\text { Top Bottom }\end{array}$ & $\begin{array}{l}\text { Length } \\
\text { Cored } \\
\text { (m) }\end{array}$ & $\begin{array}{l}\text { Recovery } \\
\text { (m) }\end{array}$ & $\begin{array}{l}\text { Recovery } \\
(\%)\end{array}$ \\
\hline $443-1$ & 28 & 2258 & $4386.0-4393.0$ & $0.0-7.0$ & 7.0 & 6.86 & 98 \\
\hline 2 & 29 & 0016 & $4393.0-4402.5$ & $7.0-16.5$ & 9.5 & 5.99 & 63 \\
\hline 3 & 29 & 0132 & $4402.5-4412.0$ & $16.5-26.0$ & 9.5 & 9.27 & 98 \\
\hline 4 & 29 & 0247 & $4412.0-4421.5$ & $26.0-35.5$ & 9.5 & 4.88 & 51 \\
\hline 5 & 29 & 0358 & $4421.5-4431.0$ & $35.5-45.0$ & 9.5 & 5.28 & 56 \\
\hline $\begin{array}{l}6 \\
7\end{array}$ & $\begin{array}{l}29 \\
29\end{array}$ & $\begin{array}{l}0559 \\
0717\end{array}$ & $\begin{array}{l}4431.0-4440.5 \\
4440.5-4450.0\end{array}$ & $\begin{array}{l}45.0-54.5 \\
54.5-64.0\end{array}$ & $\begin{array}{l}9.5 \\
9.5\end{array}$ & $\begin{array}{l}7.79 \\
9.20\end{array}$ & $\begin{array}{l}82 \\
97\end{array}$ \\
\hline 8 & 29 & 0835 & $4450.0-4459.5$ & $64.0-73.5$ & 9.5 & 6.18 & 65 \\
\hline 9 & 29 & 0948 & $4459.5-4469.0$ & $73.5-83.0$ & 9.5 & 8.72 & 92 \\
\hline 10 & 29 & 1112 & $4469.0-4478.5$ & $83.0-92.5$ & 9.5 & 9.34 & 98 \\
\hline 11 & 29 & 1230 & $4478.5-4488.0$ & $92.5-102.0$ & 9.5 & 8.43 & 89 \\
\hline 12 & 29 & 1351 & $4488.0-4497.5$ & $102.0-111.5$ & 9.5 & 2.34 & 25 \\
\hline 13 & 29 & 1517 & $4497.5-4507.0$ & $111.5-121.0$ & 9.5 & 0.55 & 6 \\
\hline 14 & 29 & 1637 & $4507.0-4516.5$ & $121.0-130.5$ & 9.5 & 8.72 & 92 \\
\hline 15 & 29 & 1745 & $4516.5-4526.0$ & $130.5-140.0$ & 9.5 & 9.48 & $99+$ \\
\hline 16 & 29 & 1908 & $4526.0-4535.5$ & $140.0-149.5$ & 9.5 & 2.60 & 27 \\
\hline 17 & 29 & 2031 & $4535.5-4545.0$ & $149.5-159.0$ & 9.5 & 5.48 & 58 \\
\hline 18 & 29 & 2148 & $4545.0-4554.5$ & $159.0-168.5$ & 9.5 & 4.43 & 47 \\
\hline 19 & 29 & 2311 & $4554.5-4564.0$ & $168.5-178.0$ & 9.5 & 3.10 & 33 \\
\hline 20 & 30 & 0045 & $4564.0-4573.5$ & $178.0-187.5$ & 9.5 & 2.77 & 29 \\
\hline 21 & 30 & 0157 & $4573.5-4583.0$ & $187.5-197.0$ & 9.5 & 2.33 & 25 \\
\hline 22 & 30 & 0322 & $4583.0-4592.5$ & $197,0-206.5$ & 9.5 & 3.06 & 32 \\
\hline 23 & 30 & 0443 & $4592.5-4602.0$ & $206.5-216.0$ & 9.5 & 6.31 & 66 \\
\hline 24 & 30 & 0602 & $4602.0-4611.5$ & $216.0-225.5$ & 9.5 & 8.34 & 88 \\
\hline 25 & 30 & 0725 & $4611.5-4620.0$ & $225.5-235.0$ & 9.5 & 3.93 & 41 \\
\hline 26 & 30 & 0835 & $4620.0-4629.5$ & $235.0-244.5$ & 9.5 & 3.22 & 34 \\
\hline 27 & 30 & 0952 & $4629.5-4639.0$ & $224.5-254.0$ & 9.5 & 5.43 & 57 \\
\hline 28 & 30 & 1112 & $4639.0-4648.5$ & $254.0-263.5$ & 9.5 & 2.30 & 24 \\
\hline 29 & 30 & 1228 & $4648.5-4658.0$ & $263.5-273.0$ & 9.5 & 6.75 & 71 \\
\hline 30 & 30 & 1347 & $4658.0-4667.5$ & $273.0-282.5$ & 9.5 & 3.00 & 32 \\
\hline 31 & 30 & 1515 & $4667.5-4677.0$ & $282.5-292.0$ & 9.5 & 6.91 & 73 \\
\hline 32 & 30 & 1634 & $4677.0-4686.5$ & $292.0-301.5$ & 9.5 & 1.66 & 17 \\
\hline 33 & 30 & 1757 & $4686.5-4696.0$ & $301.5-311.0$ & 9.5 & 3.64 & 38 \\
\hline 34 & 30 & 1907 & $4696.0-4705.5$ & $311.0-320.5$ & 9.5 & 6.77 & 71 \\
\hline 35 & 30 & 2026 & $4705.5-4716.0$ & $320.5-330.0$ & 9.5 & 3.38 & 36 \\
\hline 36 & 30 & 2145 & $4716.0-4725.5$ & $330.0-339.5$ & 9.5 & 7.10 & 75 \\
\hline 37 & 30 & 2302 & $4725.5-4735.0$ & $339.5-349.0$ & 9.5 & 1.60 & 17 \\
\hline 38 & 31 & 0030 & $4735.0-4744.5$ & $349.0-358.5$ & 9.5 & 1.75 & 18 \\
\hline 39 & 31 & 0155 & $4744.5-4754.0$ & $358.5-368.0$ & 9.5 & 2.52 & 27 \\
\hline 40 & 31 & 0320 & $4754.0-4763.5$ & $368.0-377.5$ & 9.5 & 3.15 & 33 \\
\hline 41 & 31 & 0437 & $4763.5-4773.0$ & $377.5-387.0$ & 9.5 & 0.99 & 10 \\
\hline 42 & 31 & 0548 & $4773.0-4782.5$ & $387.0-396.5$ & 9.5 & 2.05 & 22 \\
\hline 43 & 31 & 0715 & $4782.5-4792.0$ & $396.5-406.0$ & 9.5 & 3.38 & 36 \\
\hline 44 & 31 & 0838 & $4792.0-4801.5$ & $406.0-415.5$ & 9.5 & 0.20 & 2 \\
\hline 45 & 31 & 1001 & $4801.5-4811.0$ & $415.5-425.0$ & 9.5 & 2.87 & 30 \\
\hline 46 & 31 & 1124 & $4811.0-4820.5$ & $425.0-434.5$ & 9.5 & 2.65 & 28 \\
\hline 47 & 31 & 1248 & $4820.5-4830.0$ & $434.5-444.0$ & 9.5 & 0.91 & 10 \\
\hline 48 & 31 & 1410 & $4830.0-4839.5$ & $444.0-453.5$ & 9.5 & 1.65 & 17 \\
\hline 49 & 31 & 1653 & $4839.5-4849.0$ & $453.5-463.0$ & 9.5 & 5.30 & 56 \\
\hline 50 & 31 & 2042 & $4849.0-4858.5$ & $463.0-472.5$ & 9.5 & 4.92 & 52 \\
\hline 51 & 31 & 2212 & $4858.5-4863.5$ & $472.5-477.5$ & 5.0 & 0.17 & 3 \\
\hline 52 & 1 & 0218 & $4863.5-4868.0$ & $477.5-482.0$ & 4.5 & 4.52 & 100 \\
\hline 53 & i & 0810 & $4868.0-4877.5$ & $482.0-491.5$ & 9.5 & 4.19 & 44 \\
\hline 54 & i & 1427 & $4877.5-4887.0$ & $491.5-501.0$ & 9.5 & 10.28 & 108 \\
\hline 55 & 1 & 1653 & $4887.0-4890.5$ & $501.0-504.5$ & 3.5 & 2.82 & 81 \\
\hline 56 & 1 & 1935 & $4890.5-4896.5$ & $504.5-510.5$ & 6.0 & 4.49 & 75 \\
\hline 57 & i & 2230 & $4896.5-4906.0$ & $510.5-520.0$ & 9.5 & 2.60 & 27 \\
\hline 58 & 2 & 0436 & $4906.0-4915.5$ & $520.0-529.5$ & 9.5 & 5.77 & 61 \\
\hline 59 & 2 & 0857 & $4915.5-4925.0$ & $529.5-539.0$ & 9.5 & 6.56 & 69 \\
\hline 60 & 2 & 1317 & $4925.0-4934.5$ & $539.0-548.5$ & 9.5 & 8.61 & 91 \\
\hline 61 & 2 & 1912 & $4934.5-4944.0$ & $548.5-558.0$ & 9.5 & 5.28 & 56 \\
\hline 62 & 3 & 0016 & $4944.0-4953.5$ & $558.0-567.5$ & 9.5 & 4.60 & 48 \\
\hline \multirow{3}{*}{64} & 3 & 0449 & $4953.5-4963.0$ & $567.5-577.5$ & 9.5 & 10.30 & 108 \\
\hline & 3 & 1010 & $4963.0-4967.5$ & $577.5-581.5$ & 4.5 & 4.38 & 97 \\
\hline & & & & Total & 581.5 & 304.05 & 52 \\
\hline
\end{tabular}

sediment; clay minerals form the main component (more than $70 \%$ ), followed by siliceous fossils (radiolarians $4 \%$, diatoms $2 \%$, sponge spicules $1 \%$ ), quartz and feldspars $(4 \%)$, and transparent volcanic glass $(3 \%)$. In the ash layers, the amount of volcanic glass is as much as $75 \%$ per cent. Calcareous tests, few in the upper cores, increase slightly downward. Siliceous fossils a rather abundant, but gradually decrease downward. Sub-unit Ib (Cores 6 to $13,44.8$ to $121 \mathrm{~m}$ ) is marked by relatively large amounts of silt $(20-40 \%)$, calcareous materials, and scarceness of ash layers. The sediment is a nannofossil mud, a calcareous mud, or a clayey nannofossil ooze, in which carbonates form up to 55 per cent. Nannofossils generally constitute the most abundant calcareous tests; foraminifers average up to 5 per cent or are absent; unspecified carbonate minerals are common. Trace amounts of siliceous fossils occur; volcanic glass and terrigenous silt (quartz, feldspars) usually do not exceed a total of 10 per cent.

\section{Unit II}

Unit II represents a thickness of about 85 meters, from Cores 14 to 22. It is distinguished from unit I by the gray $(5 \mathrm{Y} 5 / 1)$ to greenish gray $(5 \mathrm{GY} 5 / 1)$ color, the relatively low silt content (10-20\%), the very high abundance of clay minerals (more than $80 \%$ ), and the absence or scarceness of calcareous and siliceous fossils. Sedimentary structures are not apparent, as in unit I. Two sub-units are distinguished, based on their content of volcanic material. Sub-unit IIa (Cores 14 to 19, 121 to $178 \mathrm{~m}$ ) is an ashy clay to ashy mud containing about 10 per cent volcanic glass, with rare ash layers. Sub-unit IIb (Cores 20 to 22,178 to $206.5 \mathrm{~m}$ ) is clay to mud, characterized by very large amounts of terrigenous materials: clays (up to $96 \%$ ), quartz and feldspars (3-15\%), common heavy minerals, and sporadic micas.

\section{Unit III}

Unit III is 57 meters thick and extends from Cores 23 to 28 (206.5 to $263.5 \mathrm{~m}$ ). It is distinguished from unit II by a dark-grayish-brown $(2.5 \mathrm{Y} 4 / 2)$ to grayish-brown $(2.5 \mathrm{Y} 5 / 2)$ color and by the presence of calcareous nannofossils and associated carbonates in variable amounts. Nannofossils, increasing downward from Core 22, are very abundant in the upper part of unit III ( 40 to $80 \%$ in some levels of Cores 24 and 25), then decrease. Siliceous fossils (mainly radiolarians) average 3 per cent, but locally reach 14 per cent. Ash layers are absent, and volcanic glass is rare (generally traces to $3 \%$ ). Zeolites occur in trace amounts in almost every core. There are no visible sedimentary structures, as in the overlying units.

\section{Unit IV}

Unit IV extends from Cores 29 to 38 ( 263.5 to 358.5 m). It consists chiefly of olive-gray ( $5 \mathrm{Y} 5 / 2$ to $5 \mathrm{Y} 4 / 2)$, stiff to hard mudstone, with evidence of bioturbation. The silt content generally ranges from 10 to 20 per cent, except in Cores 33 to 35, in which it reaches 40 per cent. Volcanic particles are rare (traces to $3 \%$ ). Two sub-units are distinguished, based chiefly upon the content of calcareous nannofossils and ash layers. Sub-unit IVa includes Cores 29 to $34-2$ (thickness $50.5 \mathrm{~m}$ ). It is typical inorganic mudstone (clay minerals 60 to $80 \%$; quartz and feldspars average $5 \%$, locally $15-20 \%$; micas common; heavy minerals occasional), interbedded with ash layers (glass content sometimes up to $75 \%$ in Cores 32 and 33). Siliceous remains generally form 5 per cent of the sediment, but increase in Core $31(19 \%$ at $31-1,110$ $\mathrm{cm} ; 13 \%$ at $31-2,75 \mathrm{~cm})$. Bioturbation is of minor to moderate importance, burrows being filled either by volcanic material or by common mud. Typical Zoophycos and chondrites traces can be identified. Sub-unit IVb extending from Cores 34-3 to 38 (thickness $44.5 \mathrm{~m}$ ) comprises mudstone and nannofossil chalk, the latter being represented mostly in Cores 35 and $36(40-90 \%$ 
TABLE 2

Lithologic Units at Site 443

\begin{tabular}{|c|c|c|c|c|c|c|c|}
\hline Interval & $\begin{array}{c}\text { Unit } \\
\text { Designation }\end{array}$ & $\begin{array}{l}\text { Depth and } \\
\text { Thickness } \\
(\mathrm{m})\end{array}$ & Main Color & Main Lithology & Main Components & Structure & Age \\
\hline $\begin{array}{c}443-1-1 \\
\text { to } \\
5, \mathrm{CC}\end{array}$ & Ia & $\begin{array}{l}0.0-44.8 \\
(44.8)\end{array}$ & \multirow[b]{2}{*}{$\begin{array}{l}\text { Dark greenish gray } \\
(5 G Y 4 / 1)\end{array}$} & Mud & Clay minerals & $\begin{array}{l}\text { Homogeneous; ash } \\
\text { layers }\end{array}$ & Pleistocene \\
\hline $\begin{array}{l}6 \\
\text { to } \\
13\end{array}$ & $\mathrm{Ib}$ & $\begin{array}{l}44.8-121 \\
(76.2)\end{array}$ & & $\begin{array}{l}\text { Nannofossil (cal- } \\
\text { careous mud) to } \\
\text { clayey nanno- } \\
\text { fossil ooze }\end{array}$ & $\begin{array}{l}\text { Clay minerals and } \\
\text { calcareous nanno- } \\
\text { fossils or unspeci- } \\
\text { fied carbonates }\end{array}$ & Homogeneous & Pleistocene \\
\hline $\begin{array}{l}14 \\
\text { to }\end{array}$ & IIa & $\begin{array}{l}121-178 \\
(57.0)\end{array}$ & \multirow[b]{2}{*}{$\begin{array}{l}\text { Gray }(5 Y 5 / 1) \text { to } \\
\text { greenish gray } \\
(5 \mathrm{GY} 5 / 1)\end{array}$} & Ashy clay, mud & $\begin{array}{l}\text { Clay minerals and } \\
\text { volcanic glass }\end{array}$ & $\begin{array}{l}\text { Homogeneous; } \\
\text { rare ash layers }\end{array}$ & Pliocene \\
\hline $\begin{array}{l}19 \\
20 \\
\text { to } \\
22\end{array}$ & $\mathrm{IIb}$ & $\begin{array}{l}178-206.5 \\
(28.5)\end{array}$ & & Clay, mud & $\begin{array}{l}\text { Clay minerals } \\
\text { (nannofossils in- } \\
\text { creasing in } \\
\text { Core 22) }\end{array}$ & Homogeneous & $\begin{array}{l}\text { Pliocene to } \\
\text { Miocene }\end{array}$ \\
\hline $\begin{array}{l}23 \\
\text { to } \\
28\end{array}$ & III & $\begin{array}{c}206.5-263.5 \\
\quad(57.0)\end{array}$ & $\begin{array}{l}\text { Dark grayish brown } \\
(2.5 \mathrm{Y} 4 / 2) \text { to grayish } \\
\text { brown }(2.5 \mathrm{Y} 5 / 2)\end{array}$ & $\begin{array}{l}\text { Clayey nannofos- } \\
\text { sil ooze to mud }\end{array}$ & $\begin{array}{l}\text { Clay minerals and } \\
\text { calcareous } \\
\text { nannofossils }\end{array}$ & Homogeneous & $\begin{array}{l}\text { Late } \\
\text { Miocene }\end{array}$ \\
\hline $\begin{array}{l}29 \\
\text { to } \\
34-2\end{array}$ & IVa & $\begin{array}{l}263.5-314.0 \\
\quad(50.5)\end{array}$ & \multirow{2}{*}{$\begin{array}{l}\text { Olive gray } \\
(5 Y 5 / 2-5 Y 4 / 2)\end{array}$} & Mudstone & Clay minerals & $\begin{array}{l}\text { Slight to moderate } \\
\text { bioturbation; ash } \\
\text { layers }\end{array}$ & $\begin{array}{l}\text { Late to } \\
\text { middle } \\
\text { Miocene }\end{array}$ \\
\hline $\begin{array}{l}34-3 \\
\text { to } \\
38\end{array}$ & $\mathrm{IVb}$ & $\begin{array}{l}314.0-358.5 \\
\quad(44.5)\end{array}$ & & $\begin{array}{l}\text { Nannofossil chalk } \\
\text { to mudstone }\end{array}$ & $\begin{array}{l}\text { Calcareous nanno- } \\
\text { fossils, clay } \\
\text { minerals }\end{array}$ & $\begin{array}{l}\text { Moderate to } \\
\text { strong } \\
\text { bioturbation }\end{array}$ & $\begin{array}{l}\text { Middle } \\
\text { Miocene }\end{array}$ \\
\hline $\begin{array}{l}39 \\
\text { to } \\
49-3\end{array}$ & V & $\begin{array}{l}358.5-457.0 \\
(98.5)\end{array}$ & $\begin{array}{l}\text { Dark greenish } \\
(5 \mathrm{GY} 4 / 1,5 \mathrm{GY} 5 / 1) \\
\text { with numerous } \\
\text { changes }\end{array}$ & $\begin{array}{l}\text { Claystone, mud- } \\
\text { stone, nannofos- } \\
\text { sil chalk, ash } \\
\text { (mixed or } \\
\text { changing) }\end{array}$ & $\begin{array}{l}\text { Variable: clay } \\
\text { minerals, calcare- } \\
\text { ous nannofossils, } \\
\text { unspecified car- } \\
\text { bonates, volcanic } \\
\text { glass }\end{array}$ & $\begin{array}{l}\text { Slight to strong } \\
\text { bioturbation, } \\
\text { laminae, graded- } \\
\text { beds; ash layers } \\
\text { increasing south- } \\
\text { ward; numerous } \\
\text { variations }\end{array}$ & $\begin{array}{l}\text { Middle to } \\
\text { early } \\
\text { Miocene }\end{array}$ \\
\hline
\end{tabular}

calcareous nannofossils). Ash layers are absent. Bioturbation is moderate to strong, showing a large diversity of burrow structures.

\section{Unit $\mathbf{V}$}

Unit V overlies the basaltic basement, whose uppermost flows are $\mathbf{4 5 7 . 0 5}$ meters below the sea floor. Unit V (Cores 39 to $49-3,55 \mathrm{~cm}$; thickness $98.55 \mathrm{~m}$ ) is characterized by a highly variable lithology. The main color is dark greenish gray $(5 \mathrm{GY} 4 / 1,5 \mathrm{GY} 5 / 1)$, but numerous changes occur, often at a frequency of about $10 \mathrm{~cm}$ along the cores (i.e., dark grayish brown $10 \mathrm{YR} 3 / 2$, black $5 Y 2 / 1$, olive gray $5 Y 4 / 2$, gray $5 Y 6 / 1$, greenish gray $5 \mathrm{GY} 6 / 1$, grayish green $5 \mathrm{G} 5 / 2$ ). Sediments show an irregular alternation of claystone, mudstone, nannofossil chalk, calcareous chalk, and pyroclastics. The abundance of major sedimentary components changes strongly, as does the texture (i.e., sand content in ash layers $0-90 \%$, silt $3-93 \%$, clay $5-95 \%$ ). Changes are either sharp or progressive, and some parallel laminae and normal graded bedding are evident (e.g., 49-1, 76 $\mathrm{cm})$. Bioturbation is extensive all along the cores, but shows high variability.

\section{ORGANIC GEOCHEMISTRY}

Organic-carbon and nitrogen contents were measured for 33 sediment samples. Results and discussion are in- cluded elsewhere in this volume (Waples and Sloan). The values and trends are very similar to those reported for other Leg 58 sediments. Organic-carbon and nitrogen contents are highest ( 0.4 and $0.04 \%$, respectively) near the sediment water interface and decrease with increasing depth of burial. Atomic $\mathrm{C} / \mathrm{N}$ ratios are approximately 10 in the uppermost sediments, and decrease to values of 4 to 6 in the deeper part of the sequence.

\section{INORGANIC GEOCHEMISTRY}

Eleven interstitial-water samples were taken from the sediment section cored at Hole 443. The data are summarized in Table 4 and presented on Figure 5. The measurements included $\mathrm{pH}$, salinity, chlorinity, alkalinity, and $\mathrm{Ca}^{++}$and $\mathrm{Mg}^{++}$.

\section{pH}

$p \mathrm{H}$ averages 7.78, lower than the $p \mathrm{H}$ of 7.92 and 8.27 reported for the IAPSO and surface-sea-water standards, respectively. There are four trends of $p \mathrm{H}$ within the section: values decrease with depth from 11.5 to 128.5 and 200.05 to 369.5 meters; values increase with depth from 128.5 to 200.05 and 369.5 to 456.7 meters. These trends overlap the defined sediment units. However, the data trend from 11.5 to 200.5 is a mirror image of the trend from 248.9 to 456.7 , the mirror plane existing at approximately the unit II-unit III boundary, 


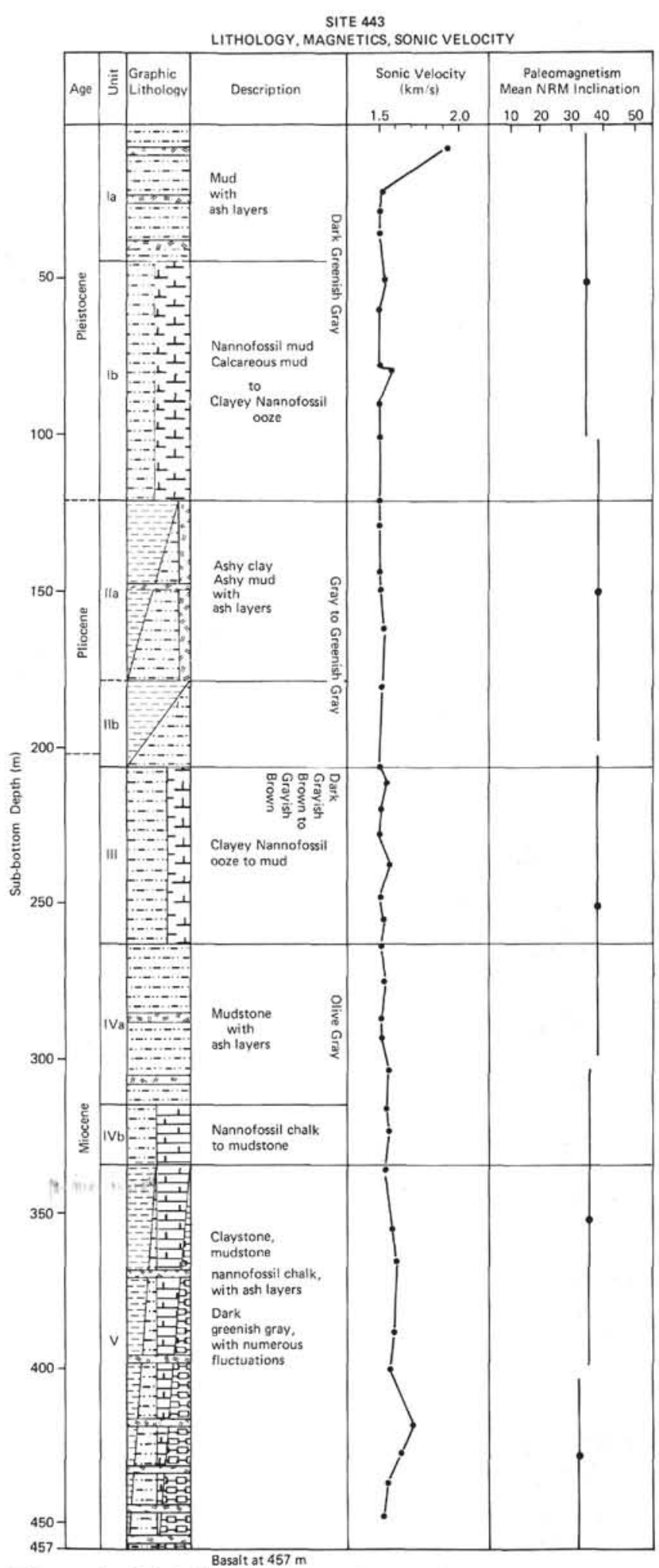

Figure 4. Lithology, magnetics, and sonic velocity of sediments, Hole 443.

which marks a boundary between upper ashy clay and mud and clay and mud, and lower mostly calcareous sediments.

\section{Salinity and Chlorinity}

Salinity averages $35 \%$, chlorinity $19.27 \%$. Salinity generally decreases with increasing depth; increases were noted from 200.05 to 268 meters and 312.5 to 369.5 meters.

Chlorinity, with exceptions, is fairly constant with increasing depth, with small points of relative increase or decrease.

The expected trend of increasing chlorinity with increasing salinity is poorly represented in these samples.

\section{Alkalinity}

Alkalinity averages $4.67 \mathrm{meq} / \mathrm{kg}$, considerably higher than the values of 2.59 and $2.52 \mathrm{meq} / \mathrm{kg}$ for the IAPSO and surface-sea-water standards. The general trend, with exceptions, is a decrease in alkalinity with increasing depth.

\section{$\mathrm{Ca}^{++}$and $\mathrm{Mg}^{++}$}

$\mathrm{Ca}^{++}$averages $14.7 \mathrm{mmol} / \mathrm{l}$, higher than the standard values. $\mathrm{Mg}^{++}$averages $44.12 \mathrm{mmol} / 1$, lower than the standard values. $\mathrm{Ca}^{++}$generally increases with increasing depth, reflecting the calcareous content within the sediment section. Low values or decreases are noted in sediment units where the carbonate content decreases or is absent. $\mathrm{Mg}^{++}$trends oppose those of $\mathrm{Ca}^{++}$, with a general decrease in values with increasing depth.

\section{BIOSTRATIGRAPHY}

Site 433 was a single-bit hole drilled in the Shikoku Basin in 4372 meters of water. It is on magnetic anomaly $6 \mathrm{~A}$, which is thought to be about 21 to $22 \mathrm{~m}$.y. old. The site objectives which utilized Paleontologic information were threefold. The age of the basement was sought to provide information on the tectonics of the basin. Second, the depositional history of the sediments within the basin was needed to identify the source and nature of hemipelagic sediments. Last, data were needed to interpret the ecological history of the basin waters. Hole 443 penetrated 457 meters of sediment before basaltic basement was encountered. Calcareous nannofossils, foraminifers and radiolarians were studied (Table 5).

Calcareous nannofossils, the best-preserved microfossils at Site 443, give the most reliable biostratigraphic information (Table 5). All three fossil groups are well represented in the Pleistocene and Holocene cores. The base of the Pleistocene is in Core 13, using nannofossils, and in Core 12 using foraminifers. Radiolarians are not found between Cores 4 and 22 and cannot be used for dating the Pliocene/Pleistocene or Miocene/Pliocene boundaries. The Pliocene is represented by a very sparse fauna in all groups of microfossils. Pliocene nannofossils are found in Cores 17 and 18.

The base of the Pliocene is placed with Core 22, in the nannofossil Amaurolithus tricorniculatus Zone.

Cores 23 to 49 are Miocene. Preservation is poor in all fossil groups, but sporadic occurrences of moderately well preserved nannofossils and radiolarians give the 
TABLE 3

Color and Smear-Slide Summary, Hole 443

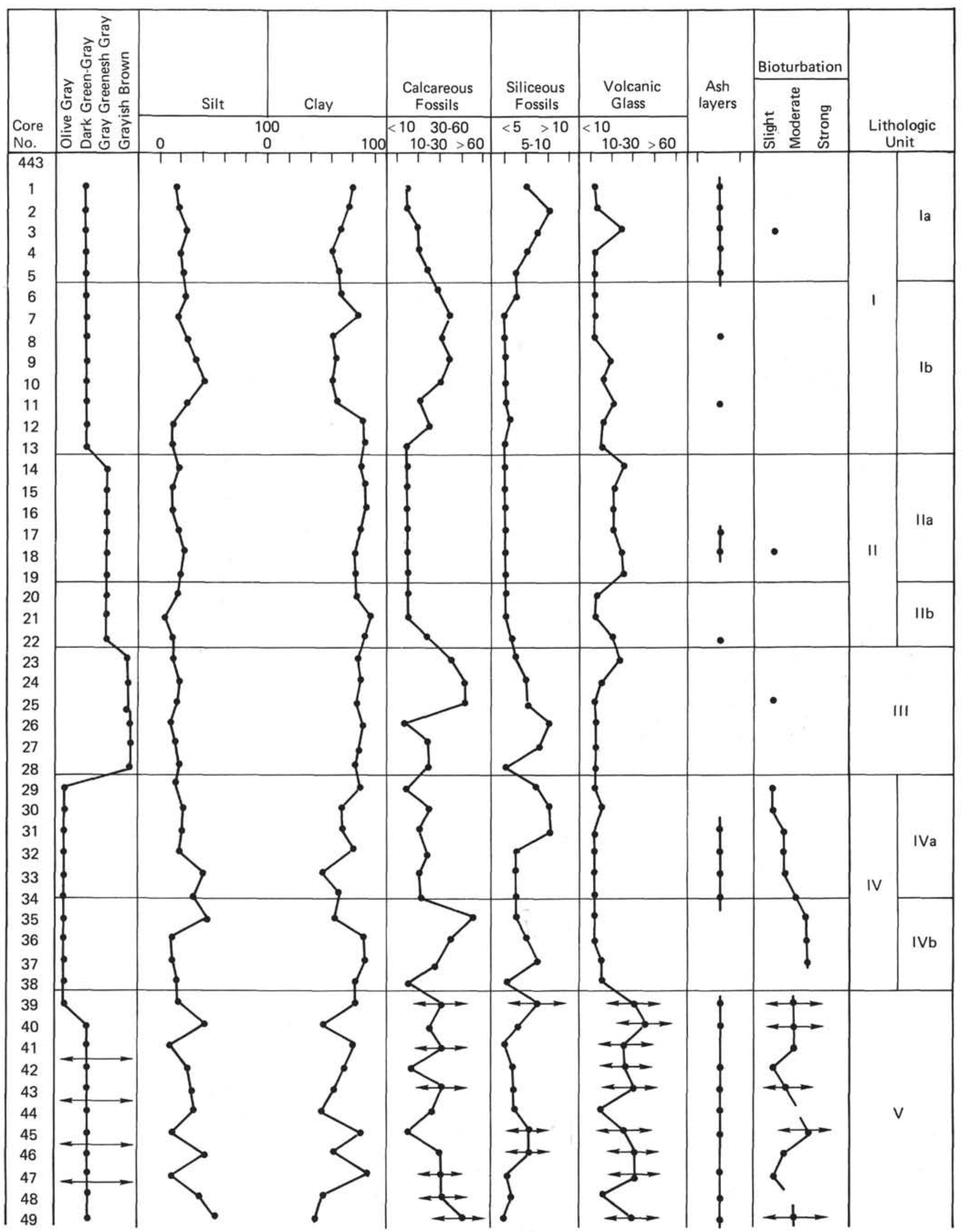


TABLE 4

Summary of Shipboard Geochemical Data for Hole 443

\begin{tabular}{ccccccccc}
\hline $\begin{array}{c}\text { Sample } \\
\text { (interval in cm) }\end{array}$ & $\begin{array}{c}\text { Sample } \\
\text { Number }\end{array}$ & $\begin{array}{c}\text { Sub-Bottom } \\
\text { Depth } \\
(\mathrm{m})\end{array}$ & $p \mathrm{H}$ & $\begin{array}{c}\text { Alkalinity } \\
(\mathrm{meq} / \mathrm{kg})\end{array}$ & $\begin{array}{c}\text { Salinity } \\
(\% / \mathrm{oo})\end{array}$ & $\begin{array}{c}\mathrm{Ca}^{++} \\
(\mathrm{mmol} / \mathrm{l})\end{array}$ & $\begin{array}{c}\mathrm{Mg}^{++} \\
(\mathrm{mmol} / \mathrm{l})\end{array}$ & $\begin{array}{c}\mathrm{Cl}^{-} \\
(\%)\end{array}$ \\
\hline- & IAPSOa & - & 7.92 & 2.59 & 35.2 & 10.55 & 53.99 & 19.375 \\
- & SSwb & - & 8.27 & 2.52 & 34.9 & 10.42 & 53.77 & 19.341 \\
$443-2-4,0-6$ & 8 & $11.50-11.56$ & 7.84 & 9.08 & 35.5 & 10.04 & 50.19 & 19.307 \\
$6-2,150-170$ & 9 & $48.00-48.20$ & 7.85 & 9.08 & 35.5 & 9.99 & 48.88 & 19.477 \\
$14-5,140-150$ & 10 & $128.40-128.50$ & 8.38 & 7.07 & 35.2 & 13.45 & 44.12 & 19.443 \\
$18-2,144-150$ & 11 & $161.94-162.00$ & 8.21 & 3.49 & 34.9 & 13.24 & 42.91 & 19.104 \\
$22-3,0-5$ & 12 & $200.00-200.05$ & 6.78 & 1.74 & 34.6 & 14.86 & 42.48 & 19.511 \\
$27-3,140-150$ & 13 & $248.90-249.00$ & 6.88 & 3.47 & 34.9 & 16.40 & 43.59 & 19.477 \\
$29-3,140-150$ & 14 & $267.90-268.00$ & 7.56 & 4.13 & 35.2 & 16.57 & 43.30 & 19.409 \\
$34-1,140-150$ & 15 & $312.40-312.50$ & 7.89 & 1.64 & 34.9 & 15.40 & 43.00 & 19.172 \\
$40-1,140-150$ & 16 & $369.40-369.50$ & 8.30 & 3.96 & 35.5 & 17.26 & 41.85 & $-\mathrm{c}$ \\
$45-1,140-150$ & 17 & $416.90-417.00$ & 8.12 & 4.08 & 35.5 & 17.77 & 42.81 & 19.579 \\
$49-3,14-18$ & 18 & $456.64-456.68$ & 7.80 & 3.61 & 33.3 & 16.74 & 42.19 & 18.255 \\
\hline
\end{tabular}

${ }^{\mathrm{a}}$ Standard sea water.

Surface sea water.

${ }^{\mathrm{c}}$ Not enough water for chlorinity.

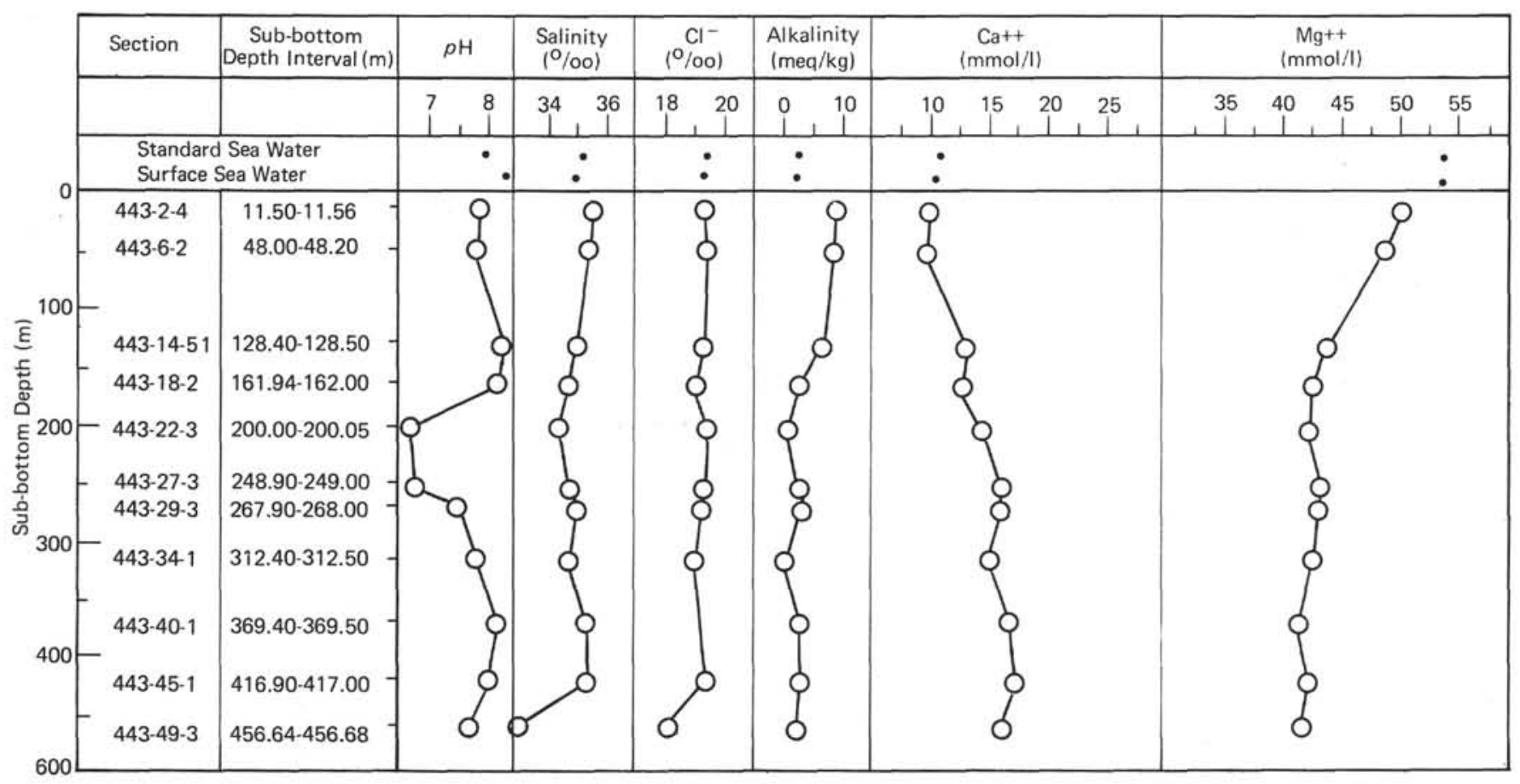

Figure 5. Interstitial-water geochemistry, Hole 443.

following ages: Cores 23 to 26 late Miocene; Cores 30 to 37 middle Miocene; Cores 39 to 49 early Miocene/middle Miocene boundary.

Preservation is poor in all fossil groups, but the preservation is better than that found at Site 442 . Cores 13 to 17 contain only a few foraminifers, and radiolarians occur only sporadically throughout the sediments. Nannofossils, although locally abundant, and rarely absent completely, show the same pattern. All fossils show some signs of mechanical breakage in the lower cores (39-49). This might be attributed to reworking, which is recorded, or to bioturbation.
The paleoecology of Site 443 suggests a Pleistocene influence of the Kuroshio Current. Tropical species are dominant, although foraminifers suggest a more-temperate fauna. This Pleistocene fauna appears moretropical than that seen at Site 442, but a high-latitude influence is still strong. Because of the poor preservation in all groups, Miocene paleoecological interpretations are difficult, but the Miocene fauna appears to be as temperate or more temperate than the Pleistocene or Holocene faunas. It is not known whether the tropical belt was narrower at this longitude in the Miocene than it is today, or if there was some other regional effect. 
TABLE 5

Biostratigraphic Zones, Site 443

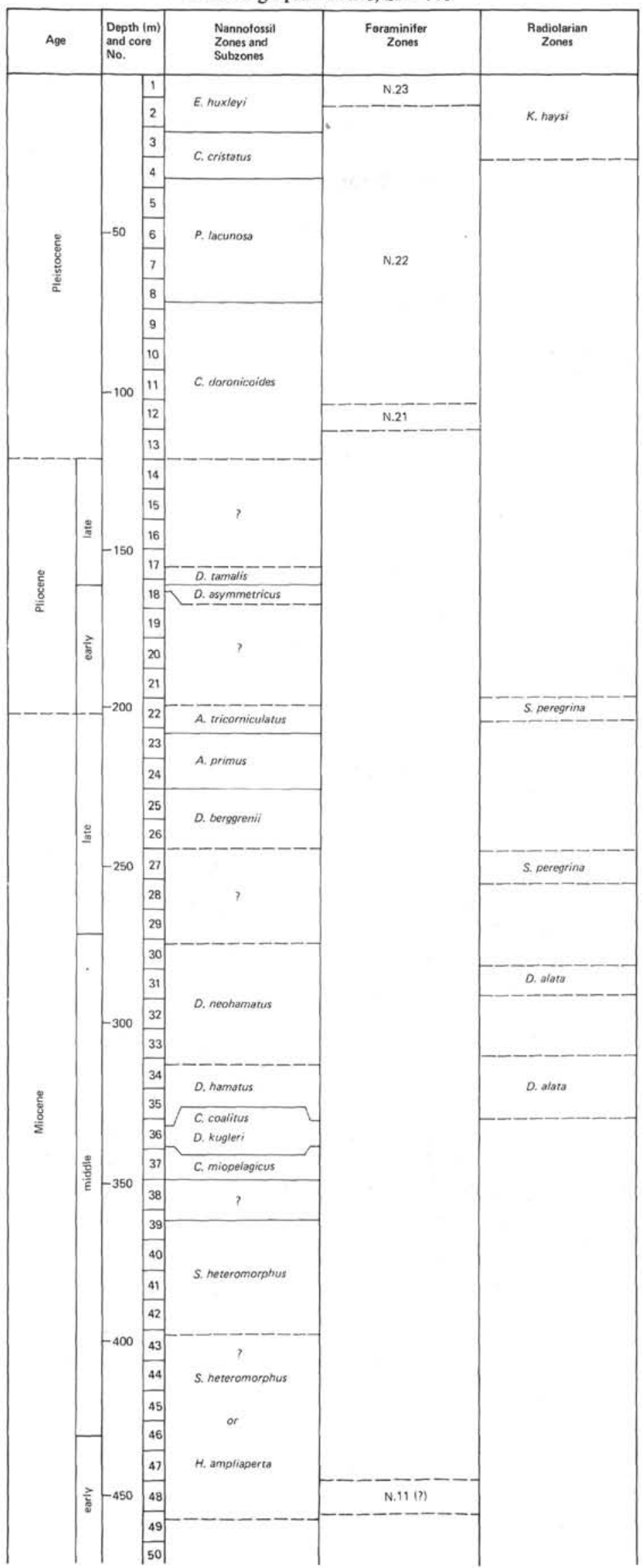


Because of the evidence of dissolution in calcareous fossils, the CCD is thought to have been close to the sea floor during the Pleistocene.

\section{Foraminifers}

Sediments recovered from Hole 443 spanned Pleistocene through middle or early Miocene (Table 5). Foraminifers occur sporadically throughout this section and show poor to moderate preservation.

Because of poor recovery of foraminifers, several section samples were processed in addition to the corecatcher material.

As in Holes 442, 442A, and 442B, sparsity and fragmentation of the foraminifers can be attributed to the depth of the CCD at time of disposition.

Cores 1 through 11 are Pleistocene. The recovered assemblages are sporadic, and preservation ranges from very poor to moderately good. The planktonic assemblages are dominated by Globorotalia inflata, a species characteristic of temperate waters. The in situ benthic assemblages are characterized by the deep-water genera Uvigerina, Pyrgo, and Melonis.

Core 12 is close to the Pleistocene/Pliocene boundary. Although the fauna is sparse, the planktonic association indicates a lower N.22/upper $\mathrm{N} .21$ foraminifer zone, approximately $1.6 \mathrm{~m} . \mathrm{y}$.

Cores 14 through 47 are essentially barren. However, scattered cores from 18 through 41 do contain fragments of benthic foraminifers.

In all the samples examined, fragmentation and dissolution were obvious. This leads to the assumption that deposition took place close to the CCD during Pleistocene time.

\section{Nannofossils}

Nannofossils of the late Pleistocene to the early Miocene were observed at this site. Nannofossils are abundant in most cores recovered, except in the Pliocene sequences, where barren intervals prevail. With a few exceptions, preservation of nannofossils is poor to moderately good, because of dissolution. The age assignment of cores is shown in Table 5.

\section{Pleistocene}

The top 13 cores contain Pleistocene nannofossils. In many of these cores, reworked Pliocene forms occur commonly. A subtropical assemblage of the Emiliania huxleyi Zone occurs in Cores 1 and 2. Cores 3-3 to 8-4 represent the Gephyrocapsa oceanica Zone. The boundary of two subzones is recognized in between Samples 4-3, $65 \mathrm{~cm}$ and 4,CC. An early-Pleistocene assemblage of the Crenalithus doronicoides Zone occurs in Cores 9 to 13. Although sporadic, the occurrence of ceratoliths indicates an influence of the Kuroshio Current during the early and late Pleistocene at this site.

\section{Pliocene}

Cores 14-1 to 17-1 are barren of nannofossils, and the Pliocene/Pleistocene boundary could not be identified precisely. Samples 17-4, $20 \mathrm{~cm}$ and 17,CC contain poor- ly preserved nannofossils of the Discoaster tamalis Subzone. Poorly preserved nannofossils also occur in Sample $18-3,66 \mathrm{~cm}$, and the assemblage indicates the late early Pliocene (Discoaster asymmetricus Subzone). Although Cores 19 and 20 yield rare to few nannofossils, further examination proved them to be contaminated by drilling. Samples 22-2, $120 \mathrm{~cm}$ and 22, CC contain abundant nannofossils of the Amaurolithus tricorniculatus Zone. Rare and sporadic ceratoliths prevent assignment to subzone. The Miocene/Pliocene boundary, therefore, could not be pinpointed, but it should be within or slightly above Core 22 .

\section{Miocene}

Cores 23 through 49 contain Miocene assemblages of nannofossils. Nannofossils occur sporadically through the sequence and are especially scarce in the middle sections. Because of excessive dissolution and non-occurrence of many key species, age identification was difficult, and subzones often were not recognized. The preservation of nannofossils is generally poor in the upper half, and considerably better in the lower half of the sequence. Sections 23-3 to 26,CC represent Discoaster quinqueramus Zone (late late Miocene), and Sample 24,CC marks the base of the Amaurolithus primus Subzone. Cores 27 to 29 are barren of nannofossils, except Sample $28-1,73 \mathrm{~cm}$, where a few placolith species with no age significance are observed. Sections $30-2$ to $35, C C$ contain nannofossils of the late middle to middle late Miocene, but the absence of Discoaster hamatus makes detailed age identification difficult. Catinaster coalitus and Discoaster kugleri also do not occur at this site. A sharp decrease of Cyclicargolithus floridanus above Section 36-5 is considered to indicate the Catinaster coalitus Zone or Discoaster kugleri Subzone for Core 36. The common C. floridanus in Cores 33 to 36 is interpreted to be reworked. Core 37 is assignable to the Coccolithus miopelagicus Subzone.

The Sphenolithus heteromorphus Zone is identified in Sections 39-2 to 43-2. In Cores 46 to 49 , poorly to moderately well-preserved, abundant nannofossils occur. The assemblage is dominated by $C$. floridanus and Discoaster deflandrei, with rare to few S. heteromorphus and Discosater exillis. These cores clearly belong either to the Helicosphaera ampliaperata Zone (15-17 m.y.) or to the $S$. heteromorphus Zone (14-17 m.y.). The common reworking observed in the upper sequences, and the absence of helicoliths, prevent identification of the age of the oldest sediment recovered at this site.

Nannofossils have suffered moderate to severe dissolution throughout the early- and middle-Miocene sequences. The degree of dissolution, however, is less, and there is slight overgrowth, within the sediment of Core 49 , which directly overlies basalt. The muddy water contained in the core barrel of Core 50 yielded abundant $D$. deflandrei with heavy overgrowth. This suggests the existence of still older sediment at this hole which was not recovered. At Site 444, the next site, a sudden increase of overgrowth was observed within the last several me- 
ters of sediment above basalt. Therefore, the time represented by the suspected missing sediment seems to be very short.

\section{Radiolarians}

Radiolarians at Site 443 show preservation and abundance patterns similar to those at Site 442. Preservation varies from good in Pleistocene and Holocene cores to moderate to poor in the rest of the cores. Biostratigraphic indicators are abundant for the Pleistocene and Holocene, but are much rarer in older sediments, making confidence in ages earlier than Pleistocene of varying certainty (Table 5). The waters in this part of the Shikoku Basin during the time the sediment of Hole 443 was being laid down were mainly tropical, but like those of Site 442, show a strong high-latitude influence.

\section{Preservation}

The pattern of preservation in Hole 443 is similar to that at Site 442 , with a few important variations. The first two preservation zones that were seen at Site 442 are also seen at this site. From Core 1 through Core 3, radiolarians are abundant and in a good state of preservation, as was seen in preservation zone 1 of Site 442 . Also, as at Site 442 , the following several cores are barren of radiolarians. In Hole 443, Cores 4 through 23 have no preserved radiolarians. The end of this preservation zone coincides with the end of lithologic unit IIb. Radiolarians are sporadic through the remainder of Hole 443.

\section{Biostratigraphy}

At Site 443, radiolarians are not of great importance in determining the age of the sediments, although there are a few sections where they support the biostratigraphy of the calcareous nannofossils. Cores 1,2, and 3 are Pleistocene to Holocene, as seen by many forms which are still extant in today's seas (Ommatartus tetrathalamus, Cornutella profunda, Spongaster tetras, Centrobotris thermophila, and Spongocore puella). Due to the poor preservation and lack of index species, confidence in pre-Quaternary zonal assignments is low. Stichocorys peregrina, Cannartus laticonus, and a form intermediate between $C$. laticonus and Ommatartus antepenultimus are found in Core 27; for this reason, it is thought to be upper Miocene, Stichocorys peregrina Zone. Core 29 contains $C$. laticonus and $C$. petterssoni, so it is tentatively assigned to the early late Miocene $(O$. antepenultimus Zone) or the late middle Miocene ( $C$. petterssoni Zone). Cores 31,34 , and 35 have a latemiddle-Miocene assemblage of Stichocorys delmontensis, Cannartus laticonus, Crytocapsella japonica, and Crytocapsella tetrapora. Because of this assemblage, these cores are assigned to the Dorcadospyris alata Zone. The final cores of Site 442 cannot be dated using radiolarians, but Core 48 contains Eucyrtidium yatuoense, which was found in the late Oligocene through early middle Miocene at Site 296 (Ling, 1975).

\section{SEDIMENTATION RATE}

An age-depth plot is shown in Figure 6. The ages of the sediment were obtained using the time scales of

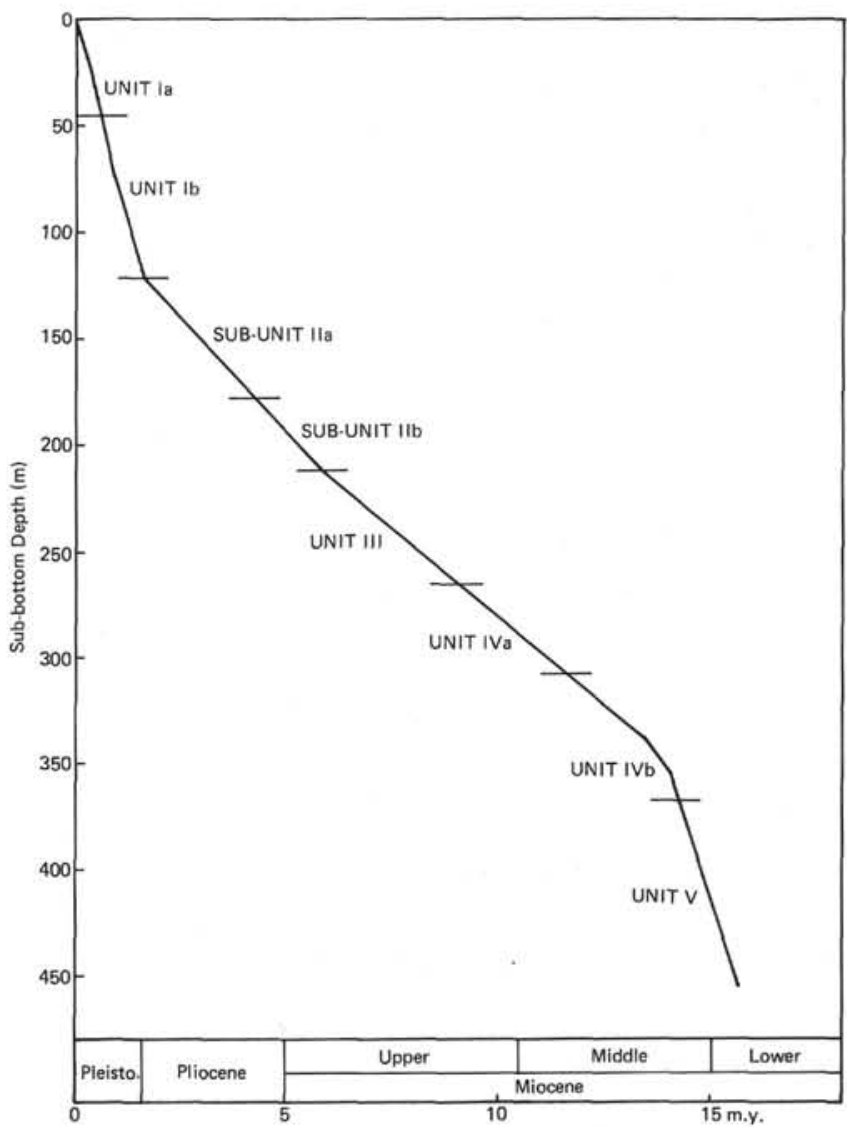

Figure 6. Sediment accumulation rate for Site 443, based on biostratigraphic age-depth determination.

Berggren (1972), Berggren and Van Couvering (1974), and Bukry (1975), and the modified Miocene scale of Saito (1977). Table 6 shows sediment accumulation rates calculated for each stratigraphic unit.

The sediment accumulation curve shows high rates of accumulation during the early middle Miocene; intermediate rates for the late middle Miocene, late Miocene, and Pliocene; and high and intermediate rates for the Pleistocene. The early-middle-Miocene sediments are hemipelagic and contain an increasing number of ash beds down-hole. These hemipelagic units also show graded bedding. Both the graded beds and the reworked nannoplankton fauna indicate resedimentation of these hemipelagic sediments from other marine areas.

TABLE 6

Sediment Accumulation Rates, Site 443

\begin{tabular}{lccc}
\hline $\begin{array}{c}\text { Lithologic } \\
\text { Unit }\end{array}$ & $\begin{array}{c}\text { Sub-Bottom } \\
\text { Depth } \\
(\mathrm{m})\end{array}$ & $\begin{array}{c}\text { Interval } \\
\text { Thickness } \\
(\mathrm{m})\end{array}$ & $\begin{array}{c}\text { Sediment } \\
\text { Accumulation } \\
\text { Rate (m/m.y.) }\end{array}$ \\
\hline Ia & $0.0-44.8$ & 44.8 & 74.7 \\
Ib & $44.8-121.0$ & 76.2 & 76.2 \\
IIa & $121.0-178.0$ & 57.0 & 21.9 \\
IIb & $178.0-206.5$ & 28.5 & 19.0 \\
III & $206.5-263.5$ & 57.0 & 17.3 \\
IVa & $263.5-314.0$ & 50.5 & 20.2 \\
IVb & $314.0-358.0$ & 44.0 & 16.9 \\
V & $358.0-457.0$ & 99.0 & 66.0 \\
\hline
\end{tabular}


Therefore, the higher rate of sediment accumulation during the early middle Miocene owes its origin to a combination of increased regional volcanism and redeposition. The increased volume of volcanic ash observed in the sediment is consistent with a known increase in explosive volcanism in the circum-Pacific and the Philippine Sea during Miocene time (Donnelly, 1975; Kennett et al., 1977).

The high rate of sediment accumulation at Site 443 during the Pleistocene is consistent with nearly identical rates during the Pleistocene at Site 442 (see Site 442 report), the Site 443 rates being somewhat lesser. The Pleistocene sediments at Site $\mathbf{4 4 3}$ contain a higher proportion of recognizable volcanic-ash layers, which indicate that increased volcanism, common to many parts of the Pacific (Kennett et al., 1977), was a cause for the increased rate of sediment accumulation. However, the large proportion of terrigenous components in the interbedded and dominant hemipelagic clays indicates that, just as at Site 442 , fluctuations in sea level during the Pleistocene also influenced the sediment accumulation rate. Such fluctuations would increase stream gradients from land source areas, increase the volume of sediment supplied to the Shikoku Basin, and reduce the distance of sediment transport.

\section{IGNEOUS PETROLOGY}

Five units were identified in the basalt sequence in Hole 443. The stratigraphic column in Figure 7 shows these units and their lithology:

\begin{tabular}{|c|c|}
\hline 1 & (457.0-457.1 m sub-bottom) \\
\hline Unit 2 & $\begin{array}{l}\text { (457.1-500.2 m sub-bottom) } \\
\text { plagioclase-olivine phyric basalt }\end{array}$ \\
\hline Unit 3 & $\begin{array}{l}\text { (500.2-538.5 m sub-bottom) } \\
\text { aphyric basalt (pillow lavas) }\end{array}$ \\
\hline Unit 4 & $\begin{array}{l}\text { (538.5-552.8 m sub-bottom) } \\
\text { plagioclase-olivine phyric basalt }\end{array}$ \\
\hline Unit 5 & $\begin{array}{l}\text { (552.8-576.5 m sub-bottom) } \\
\text { plagioclase (sparsely) phyric basalt }\end{array}$ \\
\hline Unit 6 & $\begin{array}{l}\text { (576.5-581.5 m sub-bottom) } \\
\text { olivine-plagioclase phyric basalt }\end{array}$ \\
\hline
\end{tabular}

\section{Unit 1}

Approximately 0.1 meters of microphenocryst-bearing, clinopyroxene-plagioclase glassy basalt.

\section{Unit 2}

These basalts are represented by eight massive units ranging in thickness from 0.4 meters (Core 51, Section 1 , and Core 52, Section 1) to 6.5 meters (Core 54, Section 1-5).

The massive units consist of fine-grained phyric basalts with variable contents of glomerophenocrysts of plagioclase (1-10\%), 2 to $5 \mathrm{~mm}$ in diameter. Medium-grained basalts are observed only in the thickest unit (Core 54, Sections 1-5), in which the content of plagioclase glomerophenocrysts reaches 20 per cent.

The vesicularity of the basalts ranges from 0 to 5 per cent. Vesicle diameters are as much as $2 \mathrm{~mm}$; vesicles are filled completely with calcite and smectite.
The basalts are lightly to moderately altered. The most intensively oxidized (moderately altered) rocks occur in the top and bottom of the unit. Alteration is light or absent in the central portions of the individual cooling units (Cores 49 and 50). Hydrothermal alteration of the basalts is insignificant; it is noted only within 1 or $2 \mathrm{~mm}$ of the calcite veins.

Under the microscope, the basalts from all the individual cooling units are characterized by similar textures and mineral compositions. The contact zones at the tops and bottoms of the individual units have cryptocrystalline textures which, at increasing distance from the contact, grade into intersertal, intergranular, and finally into subophitic textures in the central zones of the thickest units.

The basalt in the contact zones with cryptocrystalline (to intersertal) texture contains 1 to 10 per cent euhedral plagioclase phenocrysts $\left(\mathrm{An}_{65}\right.$ or more), 1 to $5 \mathrm{~mm}$ in diameter and 1 to 2 per cent olivine $(0.5-3.0 \mathrm{~mm})$. Ninety per cent of these rocks have devitrified glass with plagioclase needles up to $0.8 \mathrm{~mm}$. Occasional concentrations of plagioclase cause local variolitic textures in the rocks.

Intersertal and intergranular textures are typical in the basalts of unit 2 . The basalts with intersertal texture have phenocrysts of plagioclase $\left(\mathrm{An}_{65-90}\right), 1$ to $4 \mathrm{~mm}$ in diameter; these make up 1 to 10 per cent of the rock. Olivine phenocrysts represent 2 per cent of the rock; they are partially or completely replaced by a combination of serpentine and talc.

The groundmass contains thin plagioclase laths $(40-45 \% ; 0.1-1.0 \mathrm{~mm})$ and some interstitial glass (largely devitrified) in the pyroxene and plagioclase aggregate. Opaque minerals represent 1 to 2 per cent of the rock.

The basalts with intergranular texture are characterized by a finely crystalline groundmass of pyroxene and plagioclase $(0.1-1.0 \mathrm{~mm})$. Olivine $(1-2 \%)$, with a maximum diameter of $0.5 \mathrm{~mm}$, is largely replaced by serpentine and talc; these minerals now represent 3 to 4 per cent of the rock.

A subophitic texture is characteristic of the middle and lower portions of the thickest sub-unit in unit 2 (Core 54, Sections 3 and 4); it is medium-grained to coarse-grained. Euhedral plagioclase phenocrysts are in the 0.5 to $2.0 \mathrm{~mm}$ range, although larger ones are seen in hand specimens. Composition of the plagioclase is $\mathrm{An}_{60}$ or more. Individual phenocrysts of olivine with dimensions up to $3.5 \mathrm{~mm}$ are also found.

The groundmass minerals are plagioclase $(40-50 \%$, $0.1-1.0 \mathrm{~mm})$, clinopyroxene $(30-40 \%, 0.05-1.0 \mathrm{~mm})$, and opaque minerals $(2 \%)$. Olivine, together with associated secondary minerals, represents 5 to 15 per cent.

Thus, the basalts of unit 2 show (1) uniform composition and sequential change in texture in the process of crystallization; (2) olivine in virtually all cooling units; (3) gravitational differentiation in the thickest cooling unit of Unit 2, as indicated by the increased content of olivine in the middle and lower parts.

\section{Unit 3}

Unit 3 consists of intercalated aphyric pillow basalts and massive-basalt cooling units with nannofossil chalk 


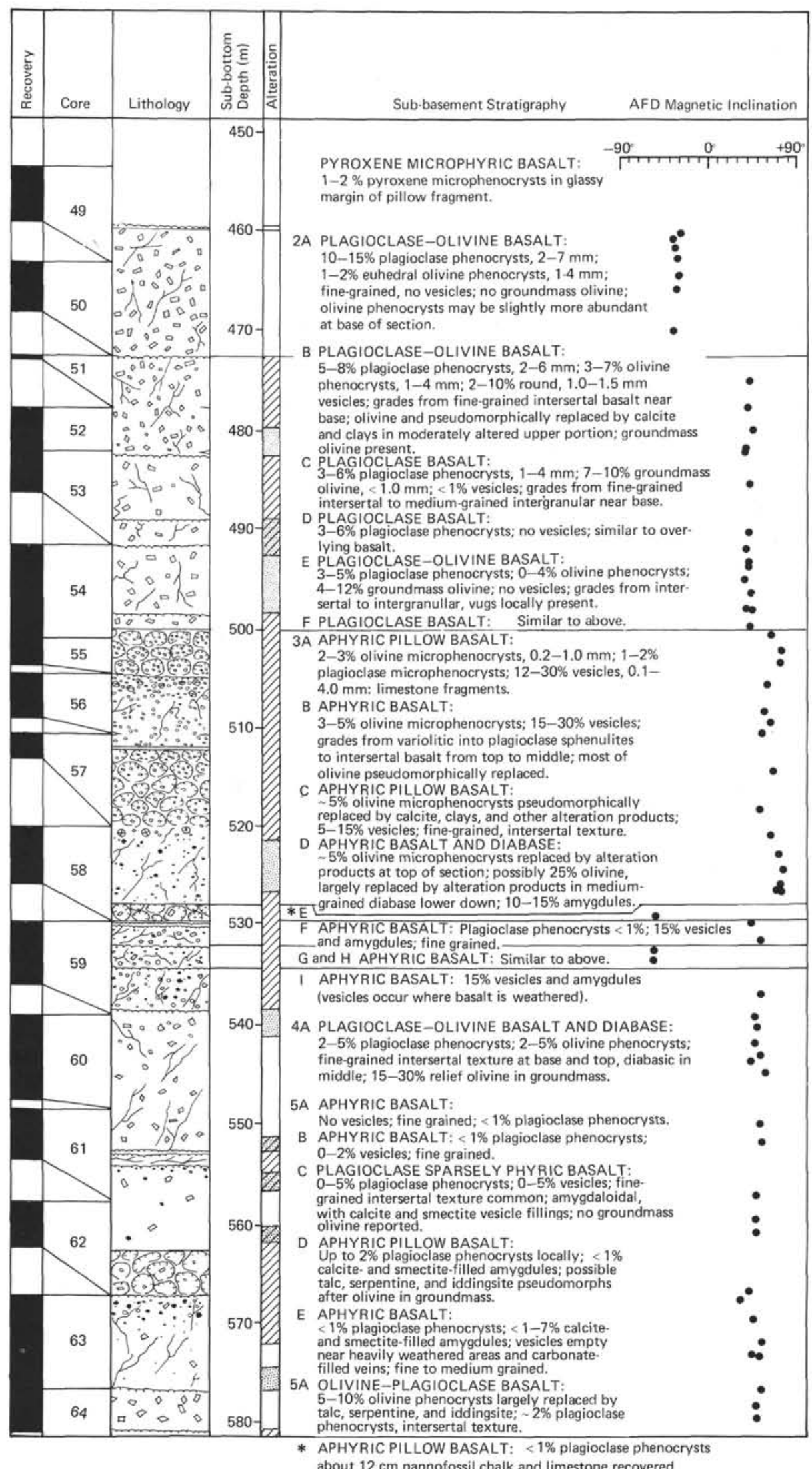

Figure 7. Sub-basement stratigraphy and magnetic inclination, Hole 443. 
and limestone locally present in small quantities. Judging from the penetration records and recoveries, unit 2 is approximately 37.8 meters thick, of which 22.2 meters $(59 \%)$ was recovered. Based on lithologic characteristics and the location of chill zones, we have divided unit 2 into nine sub-units. The upper six sub-units ( 29 meters) consist of three pillow-basalt sub-units, each with an underlying massive basalt sub-unit of similar lithology. It is assumed that each of the massive basalts represents part of the same flow as the overlyng pillow basalt, which flowed out under a carapace of rafted pillows as the flow advanced. The lower 9 meters of Unit 3 are separated from the pillow-basalt flows by $11 \mathrm{~cm}$ (actual recovery) of nannofossil chalk and limestone; this sequence consists of three massive aphyric-basalt cooling units. A K-Ar age determination on the uppermost pillow basalt gives an age of $17.2 \pm 3.1$ m.y. (E.H. McKee, pers. comm.; see Klein and Kobayashi, this volume).

Identification of the pillow basalts is based on the frequent recovery of randomly oriented pillow rinds in a given core. In the 4.5 meters of maximum penetration in sub-unit 3A for example, 19 rinds were identified. This yields an average thickness between chill zones of 0.5 meters, typical for individual basalt pillows. The thickness of the pillow rinds and their morphology varies. This is probably because of random variations in the time the pillow cooled directly in sea water, prior to burial by a newly formed pillow. The thickest recovered glass zone was $5 \mathrm{~cm}$ thick; it graded from glass to variolitic basalt and then to intersertal basalt in the pillow interior (Figure 8). Intercalated with the individual pillows were a few fragments of nannofossil limestone, possibly representing sedimentation after pillow formation, or the upsweeping of bottom sediment during formation of the pillows as the basalt flowed over the sea bottom.

The pillow basalts all have similar texture and mineralogy. They are highly vesicular (15 to $30 \%$ ) and range from intersertal to intergranular, depending on the degree of crystallization. The groundmass generally consists of quench pyroxene and plagioclase, with a feathery texture, and small acicular laths of feldspar $\left(\sim \mathrm{An}_{65}\right)$ and granules of pyroxene in the more-crystalline basalts. Titanomagnetite also occurs in the groundmass, in amounts varyng from 1 to $4 \%$ per cent; it may be granular or skeletal. Euhedral olivine microphenocrysts $\left(0.5-1.0 \mathrm{~mm} ; \sim \mathrm{Fo}_{86-90}\right)$ were present in nearly all the pillow basalts, in amounts from 1 to 5 per cent. Plagioclase microphenocrysts $(0.5-1.0 \mathrm{~mm})$ are also present in many of the basalts, but are always subordinate to olivine. Chromian spinel is a common accessory phase in the least-altered pillow basalts, generally enclosed in olivine or plagioclase microphenocrysts, but it is absent elsewhere. Alteration of the pillow basalt is variable. Olivine is completely replaced pseudomorphically by calcite in most thin sections; smectite, calcite, and possibly zeolites locally line or fill vesicles and replace the groundmass.

Although the massive basalts underlying the pillow sequences differ somewhat in mineralogy and texture, each is similar to the overlying pillow basalt. The texture

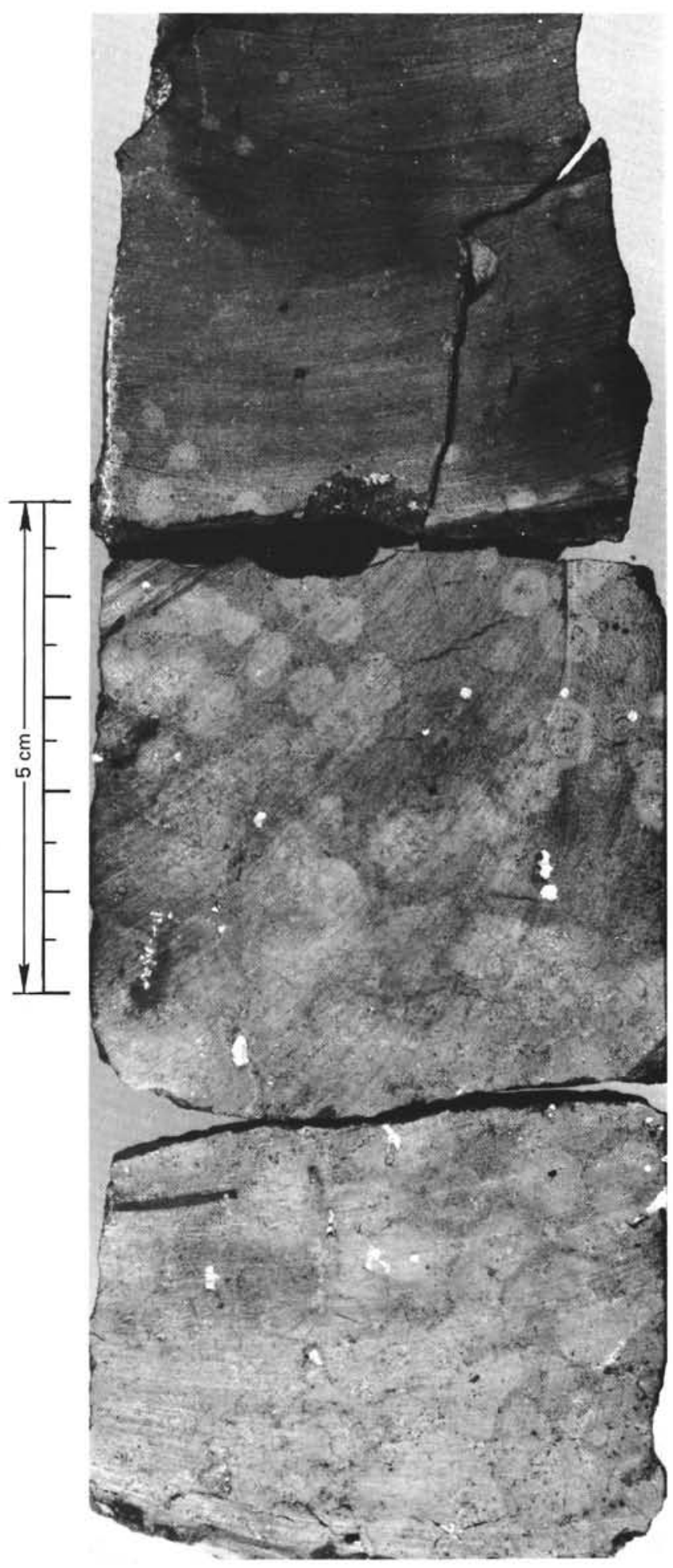

Figure 8. Glass zone showing gradation from glass to intersertal basalt.

of the massive basalt varies from intersertal at the top (similar to that of the overlying pillows), to intergranular, and finally to diabasic in the interior of the unit. One of the flows (3B) has an interesting textural variation, from variolitic near the top, to a zone of plagioclase spherulites (figure 9) in the upper middle part, and 


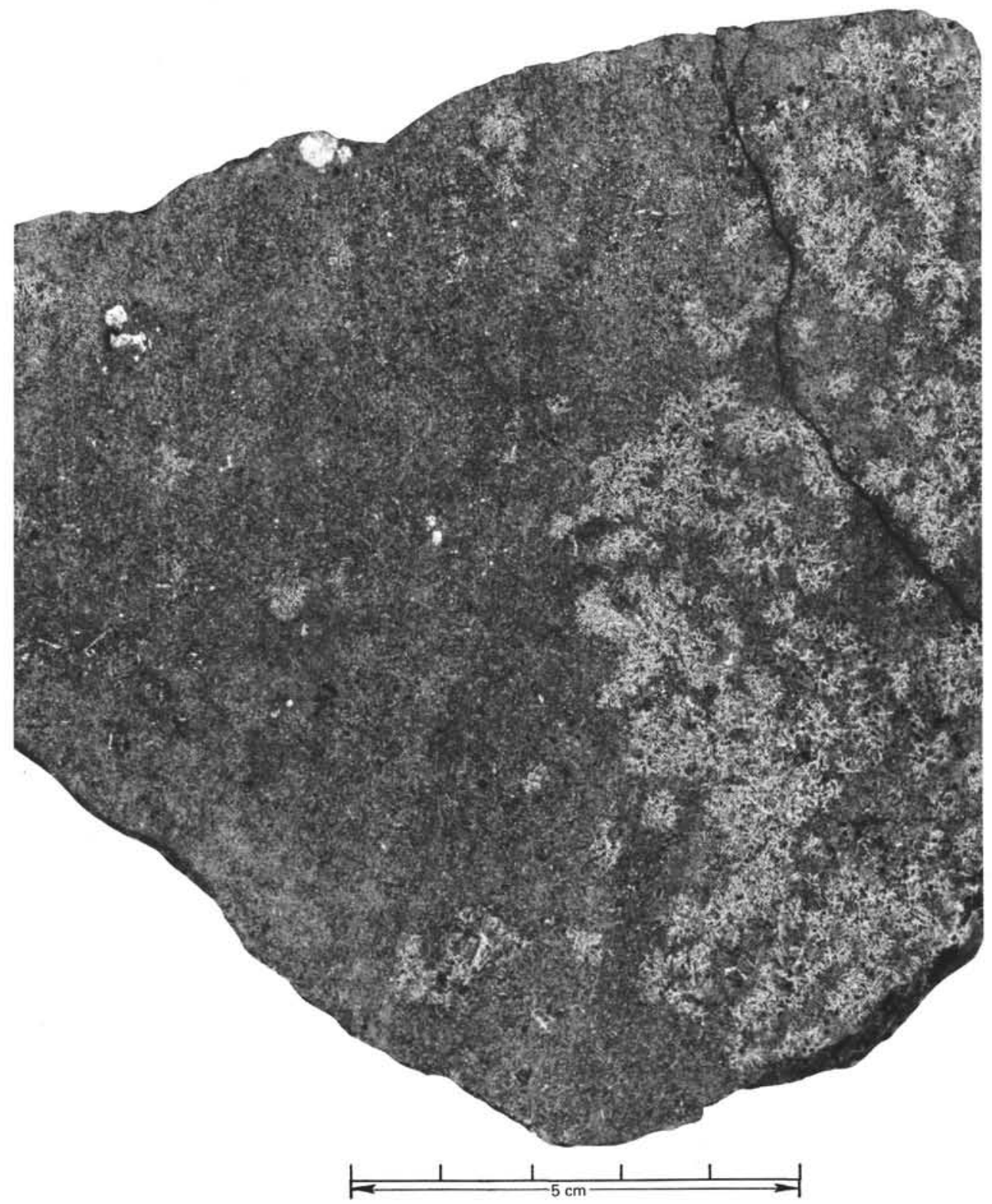

Figure 9. Textural variation from variolitic near the top, to a zone of plagioclase spherulites, into intersertal and intergranular basalt.

finally into intersertal and intergranular deep in the flow. Olivine exceeds plagioclase microphenocrysts near the top of the flow $(\sim 3-4 \%)$, but remains nearly constant in size and abundance throughout, while plagioclase and pyroxene increase in size and abundance, greatly exceeding olivine near the base of the flow. Although it is almost completely replaced, olivine appears to have occurred in the largest quantities (up to $30 \%$ ) in the center of sub-unit $3 \mathrm{D}$, which is an olivine diabase. In general, the massive basalts are highly vesicular (10-15\%) throughout unit 3, although somewhat less so than the pillow basalts. In some units, the amount of vesicles appears to increase upwards.

Because of a lack of thin sections, the lower 9 meters of unit 3 was not studied in as great detail as was the upper portion. Plagioclase phenocrysts, largely from hand- specimen descriptions, appear to be slightly more abundant, but still amount to less than 1 per cent in most of these basalts. The basalts are similar in appearance and texture to the massive aphyric basalts in the upper part of unit 3 , containing numerous vesicles $(\sim 10-15 \%)$ and ranging from fine-grained intersertal basalts to fine- to medium-grained intergranular basalts. One thin section examined from sub-unit $3 \mathrm{I}$ contained 2 to 3 per cent stubby, spongy, resorbed plagioclase grains, which clearly are the remains of a larger population of phenocrysts. These grains are strongly zoned, with calcic cores and oscillatory zoning in some grains. The groundmass plagioclase $\left(\sim \mathrm{An}_{71}\right)$ is of similar size, but consists of laths, rather than stubby, corroded crystals. Olivine may have been present, but if so it is now completely replaced. The groundmass consists of pyroxene, plagioclase, ti- 
tanomagnetite, and alteration products. The lack of overlying pillow basalts suggests that these basalts may be shallow intrusives, although in view of similar basalts higher in the section, this remains an enigma.

There appears to be an abrupt increase in the infilling of vesicles in the lower half of unit 3 . The lowermost basalts contain abundant amygdules filled with carbonate, clays, and some pyrite. Empty vesicles in the lower half of unit 3 occur chiefly in the most-alteredappearing basalt and are locally abundant adjacent to the numerous carbonate-filled veins which crisscross the entire unit.

\section{Unit 4}

Unit 4 consists of a single unit of gray, aphyric, fineto medium-grained plagioclase-olivine basalt, extending from 538.5 to 552.8 meters sub-bottom depth; 11.6 meters were recovered. The unit starts with an upper glassy margin and fine-grained, lightly altered chill zone with approximately 2 per cent vesicles (Core 59, Section 5, $110-150 \mathrm{~cm})$. The unit terminates below with another lightly altered chill zone and glassy margin (Core 61, Section 2, 135-140 cm).

Pyroxene $(0.5-1.0 \mathrm{~mm})$ and plagioclase $(0.5-2.0 \mathrm{~mm})$ phenocrysts were observed in hand specimen. The first 2 meters of the unit contain 15 to 20 per cent amygdules (1 $-10 \mathrm{~mm}$ ) containing talc and (or) smectite, often with grains of pyrite and white octahedra or cylindrical, hairlike crystals (probably zeolites).

Limited thin-section studies show that texture grades from fine-grained intersertal at the top and base to diabasic in the center.

The major constituents are plagioclase, ranging from 30 per cent near the center of the unit to 45 per cent near the top, and pyroxene, ranging from 20 to 30 per cent. Plagioclase is present as phenocrysts and microphenocrysts from 0.05 to $2.0 \mathrm{~mm}$ long and 0.02 to $0.5 \mathrm{~mm}$ wide (composition $\mathrm{An}_{64}$; Michel-Levy method). Pyroxene (augite composition) is present as acicular crystals in the quenched groundmass of the upper and lower parts of the unit and also subophitically enclosing plagioclase in the center. Some local alignment of groundmass acicular pyroxene and plagioclase laths was observed (443-60-1, 111-113 cm, piece 4; and 443-60-2, 110-112 $\mathrm{cm}$, piece $1 \mathrm{j}$ ).

Subhedral, occasionally embayed olivine phenocrysts and relict grains $(0.02-0.4 \mathrm{~mm}$ across) constitute 10 to 20 per cent of the rock and are often partially or totally replaced by serpentine, talc, and iddingsite. Cross-cutting veins lined by talc and pyrite are also common. Magnetite constitutes approximately 5 per cent, usually as finely disseminated grains (0.01-0.02 $\mathrm{mm}$ across), but larger skeletal and subhedral grains (up to $0.8 \mathrm{~mm}$ across) occur in the center of the unit. Occasional inclusions of spinel (dark red brown, $<0.02 \mathrm{~mm}$ across, square-sectioned) were observed in olivine.

Vesicles were only observed in the uppermost section (443-60-1, 111-113 cm, piece 4e), where they constitute approximately 2 per cent, ranging from 0.2 to $2.0 \mathrm{~mm}$ across. The smaller vesicles are angular to subangular; the larger vesicles are rounded.

\section{Unit 5}

Unit 5 extends from 552.8 to 576.5 meters $(8.5 \mathrm{~m}$ recovered) and is subdivided into five sub-units.

Sub-unit $5 \mathrm{~A}$ is an aphanitic lightly to moderately altered basalt with scattered plagioclase phenocrysts ( $<1 \% ; 1-2 \mathrm{~mm}$ long) lying between glassy rinds of unit 4 and sub-unit 5B (Core 61, Section 2, $140 \mathrm{~cm}$, and Core 61 , Section $3,0 \mathrm{~cm}$, respectively); $10 \mathrm{~cm}$ of material was recovered.

Sub-unit 5B is an aphyric, aphanitic to fine-grained, moderately weathered basalt, with scattered $(<1 \%)$ plagioclase phenocrysts $(1 \times 3 \mathrm{~mm}$ to $2 \times 4 \mathrm{~mm})$ and 0 to 2 per cent vesicles. The sub-unit starts with a chilled margin and glassy rind; $70 \mathrm{~cm}$ was recovered.

Sub-unit $5 \mathrm{C}$ is a series of aphyric to sparsely phyric (approximately $1 \%$ plagioclase phenocrysts; $1 \times 2 \mathrm{~mm}$ to $2 \times 4 \mathrm{~mm}$ ) flows, with one internal chill zone with a glassy margin (Core 61, Section $3,185 \mathrm{~cm}$ ) and one chill zone without a glassy margin (Core 62, Section 2, 50 $\mathrm{cm})$.

The sub-unit starts with a glassy margin and chill zone (Core 61, Section 3, $70 \mathrm{~cm}$ ) and terminates with a chill zone and glassy rind (Core 62, Section 2, $140 \mathrm{~cm}$ ); 5.1 meters was recovered.

Initially, the flows are amygdaloidal, including approximately 5 per cent vesicles $(0.5-2.0 \mathrm{~mm})$ infilled by calcite and smectite; vesicles decrease 0 to 1 per cent or less after the first 0.5 meters.

Thin sections show fine-grained quench textures (elongate and skeletal plagioclase laths with feathery aggregates of acicular pyroxene).

Plagioclase laths constitute 30 to 50 per cent of the rock, ranging from 0.05 to $0.8 \mathrm{~mm}$ in length and 0.01 to $0.2 \mathrm{~mm}$ in width (composition $\mathrm{An}_{65}$; Michel-Levy method). Plagioclase phenocrysts occur in aggregates 1 to $2 \mathrm{~mm}$ across.

Pyroxene constitutes 20 to 45 per cent of the rock and is mainly acicular (0.02-0.4 mm long), although some large phenocrysts (up to $1 \mathrm{~mm} \times 3 \mathrm{~mm}$ ) subophitically surround plagioclase laths. Small magnetite grains ( $\sim 0.01 \mathrm{~mm}$ across) constitute 2 to 7.5 per cent of the rock.

Sub-unit 5D is an aphyric, aphanitic to fine-grained basalt with scattered $(<1 \%)$ plagioclase phenocrysts. The sub-unit contains seven glassy rinds and accompanying chill zones, but variolitic zones under the glass margins are absent. Palagonite and carbonate breccia accompany the glassy margins in Core 62, Section 3, at 132 and $138 \mathrm{~cm}$.

Scattered $(<1 \%)$ carbonate- and smectite-filled amygdules (0.5-2.0 $\mathrm{mm}$ across) are present, and the sequence is frequently cut by carbonate veins. Spinel was observed as inclusions in plagioclase phenocrysts.

In thin section, these basalts are texturally similar, although finer-grained than the sub-unit $5 \mathrm{C}$ basalts. They contain around 2 per cent plagioclase phenocrysts in a groundmass of approximately 30 per cent plagioclase $\left(\sim \mathrm{An}_{67}\right), 5$ per cent magnetite, and 63 per cent pyroxene. Unlike sub-unit 5C, talc, serpentine, and iddingsite are present, probably pseudomorphically replacing olivine. 
Sub-unit $5 \mathrm{E}$ is a massive, aphyric, fine- to mediumgrained, gray basalt with occasional $(\ll 1 \%)$ plagioclase phenocrysts $(2 \mathrm{~mm} \times 1 \mathrm{~mm}$ to $3 \mathrm{~mm} \times 2 \mathrm{~mm}) ; 11.15$ meters was recovered. The sub-unit starts with a glassy rind and chilled margin (Core 63, Section 1, $0 \mathrm{~cm}$ ). The first 2.5 meters contain 3 to 7 per cent calcite- and smectite-filled amygdules (0.1-0.8 $\mathrm{mm}$ across); these are empty in the more heavily weathered areas around crosscutting calcite veins. After the first 2.5 meters, the content of amygdules decreases to 1 per cent or less.

As seen in thin sections, plagioclase $\left(\mathrm{An}_{67}\right)$ decreases with depth in the sub-unit from 45 per ent $(63-2,59-61$ $\mathrm{cm}$, piece $4 \mathrm{~b})$ to 30 per cent $(63-8,84-86 \mathrm{~cm}$, piece $2 \mathrm{~b})$. The laths range from 0.2 to $1.5 \mathrm{~mm}$ in length. Pyroxene (augite) content appears to increase slightly with depth from 25 to 30 per cent. Pyroxene crystals increase in size down the sub-unit, from 0.05 to $0.4 \mathrm{~mm}(63-2,59-61$ $\mathrm{cm}$, piece $4 \mathrm{~b})$ to 0.2 to $1.2 \mathrm{~mm}(63-8,84-86 \mathrm{~cm}$, piece $2 \mathrm{~b})$. The large pyroxene grains subophitically enclose plagioclase. All sections have a fine-grained groundmass, which is brownish green because of alteration: the alteration appears to increase down the sub-unit from 25 per cent $(63-2,59-61 \mathrm{~cm}$, piece $4 \mathrm{~b})$ to 35 per cent (63-8, 84-86 cm, piece $2 \mathrm{~b})$.

Magnetite ranges from 2 to 5 per cent of the rock, occurring as disseminated grains in the groundmass which increase in size down the sub-unit from 0.01 to $0.1 \mathrm{~mm}$ $(63-2,59-61 \mathrm{~cm}$, piece $4 \mathrm{~b})$ to 0.02 to $0.7 \mathrm{~mm}(63-8$, $84-86 \mathrm{~cm}$, piece $2 \mathrm{~b}$ ).

Alteration varies from very light to moderate around calcite veins and at the base of the unit.

\section{Unit 6}

Unit 6 consists of two sub-units. Subunit 6A starts and finishes with a chill zone and glassy margin approximately $5 \mathrm{~cm}$ thick (Core 64, Section $1,0 \mathrm{~cm}$; and Core 64 , Section $3,150 \mathrm{~cm}$, respectively). The sub-unit grades from aphanitic at top and bottom to medium-grained in the center. The basalt contains approximately 2 per cent plagioclase phenocrysts (up to $5 \mathrm{~mm}$ in length) and an occasional olivine phenocryst (1-2 mm).

In thin section, the basalts have an intersertal texture. They contain approximately 30 to 40 per cent plagioclase phenocrysts and microphenocrysts 0.1 to $1.0 \mathrm{~mm}$ long and 0.05 to $0.3 \mathrm{~mm}$ wide $\left(\mathrm{An}_{65-90}\right)$. Pyroxene $(25 \%)$ occurs as anhedral grains 0.1 to $1.0 \mathrm{~mm}$ across; some larger grains (up to $2 \mathrm{~mm}$ across) subophitically enclose plagioclase laths. Around 5 to 10 per cent olivine phenocrysts $(0.1-0.5 \mathrm{~mm}$ across) were present but are now pseudomorphically replaced by serpentine, talc, and iddingsite. Magnetite makes up 2 to 3 per cent, as 402 to $0.2 \mathrm{~mm}$ across, with odd larger grains (up to 0.6 $\mathrm{mm}$ ) with hexagonal cross-section and hollow centers. Twenty-five to 30 per cent of the rock is cryptocrystalline material, including alteration products in olivine pseudomorphs.

Cross-cutting veins lined by calcite, with accompanying oxidized alteration zones, are common.

Sub-unit $6 \mathrm{~B}$ was cored only in the top few centimeters. The sub-unit starts with a glassy margin and chill zone (Core 64, Section 4, 0-5 cm).

\section{Alteration}

Alteration of basalts at Site 443 is typical of that for oceanic basalt flows. It is observed, without exception, along all calcite veins cutting the rocks. The zone of alteration may occur within the first few millimeters or up to 1 to $2 \mathrm{~cm}$ from the edge of the vein. This type of low-temperature alteration is observed in unit 1 ; it generally is characterized by replacement of primary groundmass by calcite, smectite, and zeolites.

Higher alteration temperatures appear to characterize units 3 to 6 . Here chlorite is formed in place of calcite, smectite, and zeolites. Serpentine and talc replace olivine in all units. In Core 60, Section 1, the vesicles are filled with calcite, smectite (?), and well-formed pyrite octahedra. In the upper horizons of unit 3, an occurrence of native copper was seen in a calcite vein 2 to 3 mm thick.

Thus, although the alteration in units 3 to 6 appears to have occurred at higher temperatures than in unit 2 , the association of secondary and ore minerals shows that in general it was still a relatively low-temperature process, having occurred in the vicinity of $200^{\circ} \mathrm{C}$ or lower.

Oxidative alteration of the rocks of the top and bottom of the lava flows and along calcite veins is characteristic of the basalts in all units. This alteration yields a yellowish-gray or brownish-gray color (correspnding to light and moderate alteration, respectively). The most intensively oxidized pillow lavas of unit 2 show numerous calcite veins 1 to $3 \mathrm{~mm}$ thick.

\section{Time and Duration of the Volcanic Process}

Paleontological data for Sites 442 and 443 indicate a middle-Miocene age for the sediments immediately overlying the basalts. Thus, the miminum age for the basalt sequences of the two regions is 14 to 15 m.y. Magneticpolarity-reversal data for the two sites (Site 442 and 443 reports) indicate that the lava flows immediately underlying the unbroken sedimentary sequences at the two sites are of opposite polarity. At Site 442, the uppermost lava flow is of normal polarity; at Site 443 it is reversed. These data conclusively show that the final volcanic events at Sits 442 and 443 were not contemporaneous, in spite of the similar ages assigned from paleontological data.

Furthermore, the paleomagnetism data for Site 443 suggest at least one and possibly two zones of magneticpolarity reversal (Cores 49 and 50; Cores 58-5 and 59-1, $2,3)$. The average time between successive reversals in the Miocene is known to be about 200,000 years (Cox, 1973). The length of time required to form the 125 meters of lava flows penetrated at Site 443 was therefore probably on the order of 200,000 years.

\section{Geochemistry}

The geochemistry of these basalts is discussed in detail elsewhere in this volume. Major- and trace-element analyses from the shipboard XRF sampling program indicate that these basalts are tholeiites, lying generally within the compositional limits of abyssal 
tholeiites from both mid-ocean ridges and marginal basins.

The geochemistry and paleomagnetism evidence follow the unit lithologies closely, except for unit 2, where there appears to be a major discontinuity which had no lithologic expression.

\section{Conclusions}

1. The basalts of Site 443 are mostly olivine-bearing. Olivine-free basalts are present, but are of minor importance. The olivine basalts are analogous to oceanic basalts in composition, structure, and vesicularity $(0-5 \%$, rarely $15 \%$; only unit 3 reaches $30 \%$ ).

2. Proceeding from the top toward the middle and lower parts of the relatively thick flows, there are changes not only in the structure and texture of the rocks (from fine grained and cryptocrystalline to medium or coarse grained and aphyric), but also in the contents of olivine and opaque minerals, which increase. These changes indicate a longer time of crystallization for the thicker flows and gravitational sorting of minerals within them.

3. Alteration of the rocks increases with depth (units 3-6), but remains low-temperature. Based on the associations of secondary and ore minerals-zeolites, smectite, calcite, chlorite, pyrite, native copper-the temperatures of the hydrothermal solutions are estimated to have been $200^{\circ} \mathrm{C}$ or less.

4. The greatest degree of (oxidation) alteration is observed in the pillow lavas (unit 3) and at the tops and bottoms of flows. Within the flows, alteration has occurred along the margins of the numerous calcite veins.

5. On the basis of paleontological studies carried out during Leg 58, the age of the last eruptions of basalt around Sites 442 and 443 is 14 to $15 \mathrm{~m} . \mathrm{y}$. The opposite magnetic polarities of the uppermost lava flows at these two sites indicate that these flows were not contemporaneous.

6. The presence in the basalts of Site 443 of as many as two zones of magnetic-polarity reversal suggests a period on the order of 200,000 years for the formation of these lava flows, based upon the average frequency of magnetic reversals during the Miocene.

\section{PALEOMAGNETISM}

\section{Sedimentary Layers}

A total of 113 cylindrical core samples were taken for paleomagnetism measurements from a 457 -meter-thick sedimentary sequence at Site 443 . The sampling techniques and the measurement method for sedimenatry samples are described in the paleomagnetism section of the Site 442 report. There is, however, a slight change in the AF-demagnetization procedure. For the present series of measurements, maximum peak $\mathrm{AF}$ was fixed at $150 \mathrm{oe}$, and its decay rate was 10 milligauss/cycle. These values were obtained empirically and therefore do not have any theoretical significance. Sampling positions and results of measurements for natural remanent magnetization (NRM) and AF-demagnetized remanent magnetization (AFD) are listed in Table 7. The results are also shown diagrammatically in Figure 10, where
TABLE 7

Paleomagnetism Measurements of Sedimentary Cores from Site $443^{\mathrm{a}}$

\begin{tabular}{|c|c|c|c|c|c|c|}
\hline \multirow{2}{*}{$\begin{array}{c}\text { Sample } \\
\text { (interval in } \mathrm{cm} \text { ) }\end{array}$} & \multirow{2}{*}{$\begin{array}{c}\text { Sub- } \\
\text { bottom } \\
\text { Depth } \\
\text { (m) }\end{array}$} & \multirow{2}{*}{$\begin{array}{l}J_{\text {NRM }} \\
\left(10^{-5}\right. \\
\text { gauss })\end{array}$} & \multirow{2}{*}{$\begin{array}{c}\text { Suscepti- } \\
\text { bility } \\
\left(10^{-5}\right. \\
\text { gauss/oe) }\end{array}$} & \multicolumn{2}{|c|}{ Inclination } & \multirow{2}{*}{$\begin{array}{l}\text { Polar- } \\
\text { ity }\end{array}$} \\
\hline & & & & NRM & AFD & \\
\hline $443-1-1,125-127$ & 1.25 & 1.41 & 0.53 & 17.6 & 15.8 & + \\
\hline $1-4,108-110$ & 5.59 & 1.60 & 0.66 & -13.1 & -14.1 & - \\
\hline $2-1,71-73$ & 7.71 & 71.60 & 0.93 & -15.6 & -11.1 & - \\
\hline $2-3,45-47$ & 10.46 & 5.79 & 0.63 & 83.6 & 15.1 & + \\
\hline $3-1,16-18$ & 16.67 & 1.89 & 0.72 & 47.4 & 58.7 & + \\
\hline $3-2,77-79$ & 18.78 & 5.24 & 0.73 & 17.6 & 15.3 & + \\
\hline $3-5,84-86$ & 23.35 & 1.70 & 0.55 & -37.8 & -35.5 & - \\
\hline $4-1,111-113$ & 27.12 & 1.12 & 0.73 & -73.5 & -74.3 & - \\
\hline $42,109-111$ & 28.60 & 0.43 & 0.83 & -47.2 & -39.8 & - \\
\hline $4-3,39-41$ & 29.40 & 1.28 & 0.72 & 77.5 & 78.3 & + \\
\hline $4-3,45-47$ & 29.46 & 2.13 & 0.96 & 82.9 & 84.4 . & + \\
\hline $5 \cdot 1,61-63$ & 36.12 & 1.84 & 0.74 & 11.8 & 16.8 & + \\
\hline $5-2,36-38$ & 37.37 & $0.014^{b}$ & 0.69 & 16.9 & 83.5 & + \\
\hline $5-3,99-101$ & 39.50 & $0.054^{b}$ & 0.61 & -60.6 & -72.4 & - \\
\hline $5-4,31-33$ & 40.32 & $0.26^{b}$ & 0.86 & 4.0 & 6.8 & + \\
\hline $6-2,44-46$ & 47.95 & $0.19 \mathrm{~b}$ & 0.80 & -10.0 & -19.4 & - \\
\hline $6-3,44-46$ & 48.45 & 1.28 & 0.96 & 59.2 & 62.8 & + \\
\hline $6-4,44-46$ & 49.95 & 3.46 & 0.86 & 4.0 & 4.3 & + \\
\hline $6-5,44-46$ & 51.45 & 1.29 & 0.67 & -31.2 & -31.9 & - \\
\hline $8-4,106-108$ & 69.57 & $0.04^{b}$ & 0.75 & -36.6 & -38.8 & - \\
\hline $8-5,58-60$ & 70.59 & $0.06^{\mathrm{b}}$ & 0.60 & 6.1 & 14.1 & + \\
\hline $9-5,26-28$ & 79.77 & $0.0005^{b}$ & 0.53 & -58.5 & -51.8 & - \\
\hline $10-1,69-71^{c}$ & 83.70 & 1.24 & 0.81 & 30.1 & 11.5 & + \\
\hline $10-1,138-140^{c}$ & 84.39 & 0.91 & 0.74 & -10.3 & -16.0 & - \\
\hline $10-2,39-41^{c}$ & 84.90 & 1.01 & 0.74 & 33.5 & 36.7 & + \\
\hline $10-2,138-140^{c}$ & 85.89 & 1.04 & 0.30 & -77.5 & -74.8 & - \\
\hline $10-3,43-45 \mathrm{c}$ & 86.44 & 0.68 & 0.13 & 12.4 & 17.3 & + \\
\hline $10-4,51-53^{c}$ & 88.02 & 0.58 & 0.19 & -72.8 & -55.3 & - \\
\hline $10-4,135-137 \mathrm{c}$ & 88.86 & 26.88 & 0.26 & -13.1 & -15.0 & - \\
\hline $10-5,48-50^{c}$ & 89.49 & 0.57 & 0.19 & -41.7 & -36.8 & - \\
\hline $10-5,132-135^{c}$ & 90.33 & 1.73 & 0.25 & 14.7 & 5.8 & + \\
\hline $10-6,108-110$ & 91.59 & 1.47 & 0.19 & 8.5 & 13.9 & + \\
\hline $11-2,108-110^{b}$ & 95.09 & 0.48 & 0.19 & 35.2 & 35.1 & + \\
\hline $11-3,108-110$ & 96.59 & 1.01 & 0.29 & -23.2 & -23.2 & - \\
\hline $11-4,108-110$ & 98.09 & 1.35 & 0.21 & 15.2 & 10.4 & + \\
\hline $11-5,108-110$ & 99.59 & 2.39 & 0.21 & 48.7 & 46.5 & + \\
\hline $11-6,70-72$ & 100.71 & 1.84 & 0.26 & 58.7 & 63.1 & + \\
\hline $14-4,120-122$ & 126.70 & $0.08^{b}$ & 0.33 & 7.6 & 24.4 & + \\
\hline $14-5,120-122$ & 128.21 & 3.87 & 0.36 & 32.5 & 31.9 & + \\
\hline $14-6,106-108$ & 129.57 & 3.81 & 0.46 & 0.4 & 2.9 & $+1-$ \\
\hline $15-4,48-50$ & 135.49 & $0.56^{\mathrm{b}}$ & 0.24 & 56.2 & 64.6 & + \\
\hline $15-5,63-65$ & 137.14 & $0.71^{\mathrm{b}}$ & 0.29 & 35.0 & 35.4 & + \\
\hline $15-6,63-65$ & 138.64 & 2.35 & 0.27 & 61.8 & 60.3 & + \\
\hline $15-7,28-30$ & 139.79 & 2.23 & 0.30 & 32.1 & 30.1 & + \\
\hline $17-4,11-13$ & 154.12 & 2.42 & 0.33 & -24.7 & -24.1 & - \\
\hline $18-1,98-100$ & 159.99 & 2.32 & 0.24 & -60.6 & -63.9 & - \\
\hline $18-2,98-100$ & 161.49 & 1.78 & 0.39 & -54.9 & -59.1 & - \\
\hline $18-3,98-100$ & 162.99 & 0.54 & 0.57 & -31.4 & -29.4 & - \\
\hline $21-2,13-15$ & 189.14 & 3.11 & 0.39 & 38.7 & 38.1 & + \\
\hline $23-1,110-112$ & 207.61 & 1.31 & 0.31 & 54.3 & 50.7 & + \\
\hline $23-2,95-97$ & 208.96 & 0.73 & 0.48 & 8.9 & -4.1 & $+1-$ \\
\hline $23-3,40-42$ & 209.91 & 0.55 & 0.40 & 58.0 & 57.2 & + \\
\hline $23-4,50-52$ & 211.51 & 2.09 & 0.39 & 42.5 & 46.8 & + \\
\hline $241,70-72$ & 216.71 & 2.75 & 0.43 & -43.2 & -44.4 & - \\
\hline $24-3,90-92$ & 219.91 & 2.24 & 0.37 & -70.2 & -65.0 & - \\
\hline $24-4,95-97$ & 221.46 & 1.55 & 0.38 & 68.7 & 70.8 & + \\
\hline $24-5,71-73$ & 222.72 & 0.25 & 0.72 & -9.0 & 16.8 & $-1+$ \\
\hline $24-6,74-76$ & 224.25 & 1.78 & 0.41 & 48.7 & 40.0 & + \\
\hline $25-2,72-74$ & 227.73 & 15.09 & 2.40 & -56.9 & -53.4 & - \\
\hline $25-2,123-125$ & 228.24 & 2.16 & 0.46 & -42.0 & -42.2 & - \\
\hline $25-3,86-88$ & 229.31 & 0.47 & 1.18 & 13.4 & 35.7 & + \\
\hline $26-1,82-84$ & 235.83 & 3.20 & 0.48 & -36.0 & -37.1 & - \\
\hline $26-2,142-144$ & 237.92 & 1.56 & 0.74 & 41.7 & 40.7 & + \\
\hline $27-1,80-82$ & 245.31 & 0.37 & 0.36 & -20.1 & 19.3 & $-1+$ \\
\hline $27-2,22-24$ & 246.21 & 0.59 & 0.35 & -33.3 & -17.1 & . \\
\hline $27-3,11-13$ & 247.62 & 1.50 & 0.46 & 55.6 & 65.8 & + \\
\hline $27-4,55-57$ & 249.56 & 1.21 & 0.38 & -33.7 & -14.5 & - \\
\hline $28-1,108-110$ & 255.09 & 1.54 & 0.40 & -41.6 & -28.3 & - \\
\hline $28-2,16-18$ & 255.67 & 4.49 & 0.22 & -24.6 & -23.2 & - \\
\hline $29-1,87-89$ & 264.38 & 3.72 & 0.24 & -39.0 & -33.7 & - \\
\hline $29-2,61-63$ & 265.62 & 1.42 & 0.24 & -5.8 & 1.2 & $-1+$ \\
\hline $29-3,85-87$ & 267.36 & 2.95 & 0.22 & -55.2 & -54.0 & - \\
\hline $29-4,56-58$ & 268.57 & 5.79 & 0.37 & -41.9 & -39.8 & - \\
\hline $29-5,46-48$ & 269.97 & 3.89 & 0.39 & -42.4 & -38.0 & - \\
\hline $30-2,132-134$ & 275.83 & 2.49 & 0.30 & -54.0 & -58.2 & - \\
\hline
\end{tabular}


TABLE 7 - Continued

\begin{tabular}{|c|c|c|c|c|c|c|}
\hline \multirow{2}{*}{$\begin{array}{c}\text { Sample } \\
\text { (interval in } \mathrm{cm} \text { ) }\end{array}$} & \multirow{2}{*}{$\begin{array}{c}\text { Sub- } \\
\text { bottom } \\
\text { Depth } \\
\text { (m) }\end{array}$} & \multirow{2}{*}{$\begin{array}{l}J_{\mathrm{NRM}} \\
\left(10^{-5}\right. \\
\text { gauss })\end{array}$} & \multirow{2}{*}{$\begin{array}{c}\text { Suscepti- } \\
\text { bility } \\
\left(10^{-5}\right. \\
\text { gauss/oe) }\end{array}$} & \multicolumn{2}{|c|}{ Inclination } & \multirow{2}{*}{$\begin{array}{l}\text { Polar- } \\
\text { ity }\end{array}$} \\
\hline & & & & NRM & AFD & \\
\hline $31-1,119-121$ & 283.70 & 1.61 & 0.39 & 14.8 & 30.3 & + \\
\hline $31-2,62-64$ & 284.63 & 7.03 & 0.89 & 20.6 & 26.1 & + \\
\hline $31-3,44-46$ & 285.95 & 4.30 & 056 & 44.7 & 43.9 & + \\
\hline $31-4,44-46$ & 287.45 & 3.00 & 0.68 & 58.6 & 69.6 & + \\
\hline $31-5,30-32$ & 288.81 & 1.11 & 0.54 & 11.4 & 29.0 & + \\
\hline $32-1,129-131$ & 293.30 & 4.93 & 1.14 & 23.5 & 29.0 & + \\
\hline $33-1,38-40$ & 301.89 & 9.62 & 1.25 & 38.1 & 42.8 & + \\
\hline $33-2,38-40$ & 303.39 & 3.67 & 0.42 & 40.6 & 42.0 & + \\
\hline $33-3,38-40$ & 304.89 & 6.33 & 0.85 & -41.3 & -37.6 & - \\
\hline $34-2,11-13$ & 312.62 & 3.00 & 0.53 & 40.7 & 41.0 & + \\
\hline $34-3,11-13$ & 314.12 & 1.60 & 0.75 & -56.5 & -28.6 & - \\
\hline $34-4,11-13$ & 315.62 & 2.67 & 0.56 & 7.3 & 8.3 & + \\
\hline $34-5,11-13$ & 317.12 & 5.37 & 0.94 & 52.2 & 49.1 & + \\
\hline $35-1,56-58$ & 321.07 & 2.90 & 0.71 & -37.8 & -42.7 & - \\
\hline $35-3,07-09$ & 323.59 & 1.74 & 0.63 & 49.7 & 51.7 & + \\
\hline $36-1,36-38$ & 330.37 & 3.19 & 0.59 & 4.1 & 8.0 & + \\
\hline $36-2,103-105$ & 332.54 & 3.59 & 0.79 & -51.3 & -54.0 & - \\
\hline $36-3,89-91$ & 333.90 & 5.26 & 0.65 & -37.3 & -34.6 & - \\
\hline $36-4,114-116$ & 335.65 & 3.92 & 0.68 & -36.5 & -33.5 & - \\
\hline $36-5,87-89$ & 336.88 & 0.44 & 0.51 & -15.6 & 32.4 & $-1+$ \\
\hline $39-1,76-78$ & 359.27 & 1.48 & 0.77 & -58.8 & -66.0 & - \\
\hline $39-1,129-131$ & 359.80 & 3.84 & 0.52 & -48.6 & -50.9 & - \\
\hline $39-2,50-52$ & 360.49 & 4.97 & 0.54 & -43.3 & -42.2 & - \\
\hline $40-1,56-58$ & 368.57 & 4.07 & 0.84 & 46.1 & 51.2 & + \\
\hline $40-2,10-12$ & 369.61 & 3.28 & 0.68 & 21.2 & 24.6 & + \\
\hline $42-1,66-68$ & 387.67 & 5.34 & 0.35 & -33.1 & -32.9 & - \\
\hline $42-2,13-15$ & 388.64 & 5.20 & 0.36 & 23.3 & 21.2 & + \\
\hline $43-1,38-40$ & 396.89 & 4.01 & 0.38 & 26.5 & 27.5 & + \\
\hline $43-2,78-80$ & 398.79 & 6.62 & 0.67 & 34.4 & 37.5 & + \\
\hline $45-1,79-81$ & 416.30 & 5.25 & 0.60 & -32.2 & -34.4 & - \\
\hline $45-2,67-69$ & 417.68 & 8.19 & 0.75 & -34.7 & -36.3 & - \\
\hline $46-1,44-46$ & 425.45 & 2.58 & 0.66 & 12.2 & 21.2 & + \\
\hline $46-2,44-46$ & 426.95 & 4.83 & 0.77 & 12.3 & 17.0 & + \\
\hline $47-1,36-38$ & 434.87 & 2.80 & 0.57 & 63.4 & 60.6 & + \\
\hline $48-1,129-131$ & 445.30 & 3.09 & 0.43 & 47.1 & 47.1 & + \\
\hline $49-2,25-27$ & 455.25 & 1.86 & 0.46 & -56.1 & -62.9 & - \\
\hline $49-2,114-116$ & 456.15 & 1.01 & 0.46 & -8.1 & 20.5 & $-1+$ \\
\hline
\end{tabular}

${ }^{a}$ AFD is obtained by peak alternating demagnetizing field of $150 \mathrm{oe}$, decreasing to zero at a constant rate of 20 milligauss/cycle; polarity shows whether the inclination of NRM is positive $(+)$ or negative $(-)$.

Weak.

${ }^{\mathrm{c}}$ Soupy.

"normal" and "reversed" denote that the inclination of both of the NRM and AFD is positive (down-dipping) or negative (up-dipping), respectively. Absolute values of NRM inclination for all the samples are plotted in Figure 11. Sedimentary layers are arbitrarily divided into 100 -meter intervals of sub-bottom depth, and a statistical treatment was applied to absolute values of inclination for each group. The results of calculation are tabulated in Figure 11.

\section{Basalt Layers}

A total of 63 basalt samples were taken from a 115.5-meter-thick basalt sequence. Fifty-eight of them were AF demagnetized in a stepwise manner. AF demagnetization was applied until the remanent magnetization decreases below half of its initial value. Inclination of the AF-demagnetized remanent magnetization (AFD) is given for the field next higher than the MDF (median destructive field). The data for sampling and magnetism measurements are listed in Table 8. Stability of remanent magnetization against $\mathrm{AF}$ is different from sample to sample, as shown in Figure 12. MDF of some samples was found to be lower than 50 oe at the peak
AF. NRM of samples with low MDF is unstable and changes direction by more than 5 degrees through $\mathrm{AF}$ demagnetization up to MDF. Distortion of the original NRM seems to have occurred by remagnetization during drilling procedures.

However, it is surprising to find that the original remanent magnetization seems to be well preserved within basalts deep under the ocean floor. This is clearly shown in Figure 13, where the inclination of stable remanent magnetization of basalt samples is plotted with respect to core and section. It is shown that there are four groups of inclination values, with sharp discontinuities at depths around Core 51, the top of Core 55, and the middle of Core 58. Statistics in Table 9 confirm that the four populations of inclination values are completely independent of each other.

\section{Summary and Discussion}

The results of paleomagnetism measurements are summarized as follows:

1. Stability of NRM of paleomagnetism samples from the drilled cores is sufficiently high to provide data about the paleomagnetic-field direction. Koenigsberger ratios range from 5 to 20 for most of the sediment samples and from 20 to 2000 for the basalt samples.

2. Intensity of NRM of basalt samples ranges from 2 to $10 \times 10^{-3}$ gauss $/ \mathrm{cm}^{3}$.

3. The lowermost sedimentary layers carry reversed remanent magnetization, which continues to the top of the basalt layers. Their average NRM inclinations are similar: -33 degrees for sediments and -31 degrees for basalts.

4. Statistical means of absolute values of NRM inclination are slightly lower than the inclination of the recent geomagnetic dipole field at Site 443 (estimated $47.9^{\circ}$ ). Mean values for every 100 meters of sub-bottom depth range from 33 to 39 degrees, the standard deviation ranging from 15 to 26 degrees.

5. There are four statistically different populations with respect to NRM inclination values (strictly, absolute values of NRM inclination) within basalt layers.

6 . Through the entire basalt sequence, two normal and two reversed NRM zones were identified.

Taking into account these results, we conclude:

1. NRM inclinations of the lower part of the sediments and the top of basalts at Sites 442 and 443 are dispersed between 30 and 37 degrees, implying that the paleolatitude of this area during the early middle Miocene was a little lower than at present.

2. Basalts at Site 443 are similar to typical oceanic basalts with respect to their NRM intensity and Koenigsberger ratio.

3. The top of the basalt and the lowermost layer of the sediments are probably of the same geologic age in terms of geomagnetic polarity change.

4. Basaltic layers of Site 443 were probably formed through four episodes of volcanic activity, interrupted for longer than 1000 years each time.

5. Assuming that the average period of a single geomagnetic-polarity event in the early middle Miocene was about 0.2 m.y., 100 meters of the top layer of basalts at 
Normal $\square$ Reversed $\quad$ Not Sampled or No Recovery

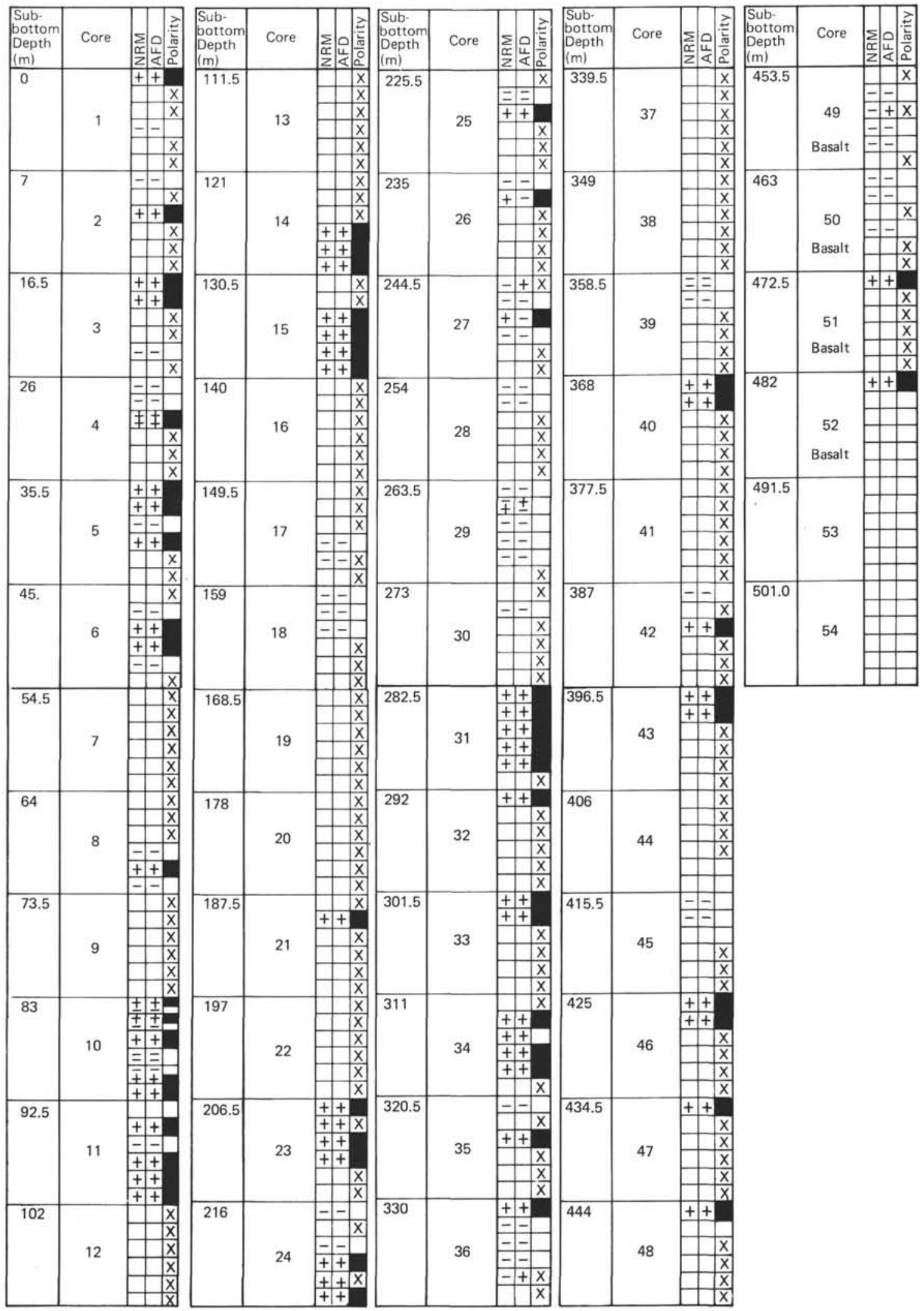

Figure 10. Results listed in Table 7, illustrated in descending order of cores and section. Polarity diagrams of some basaltic cores next to the bottom layer of sediments are also shown. 


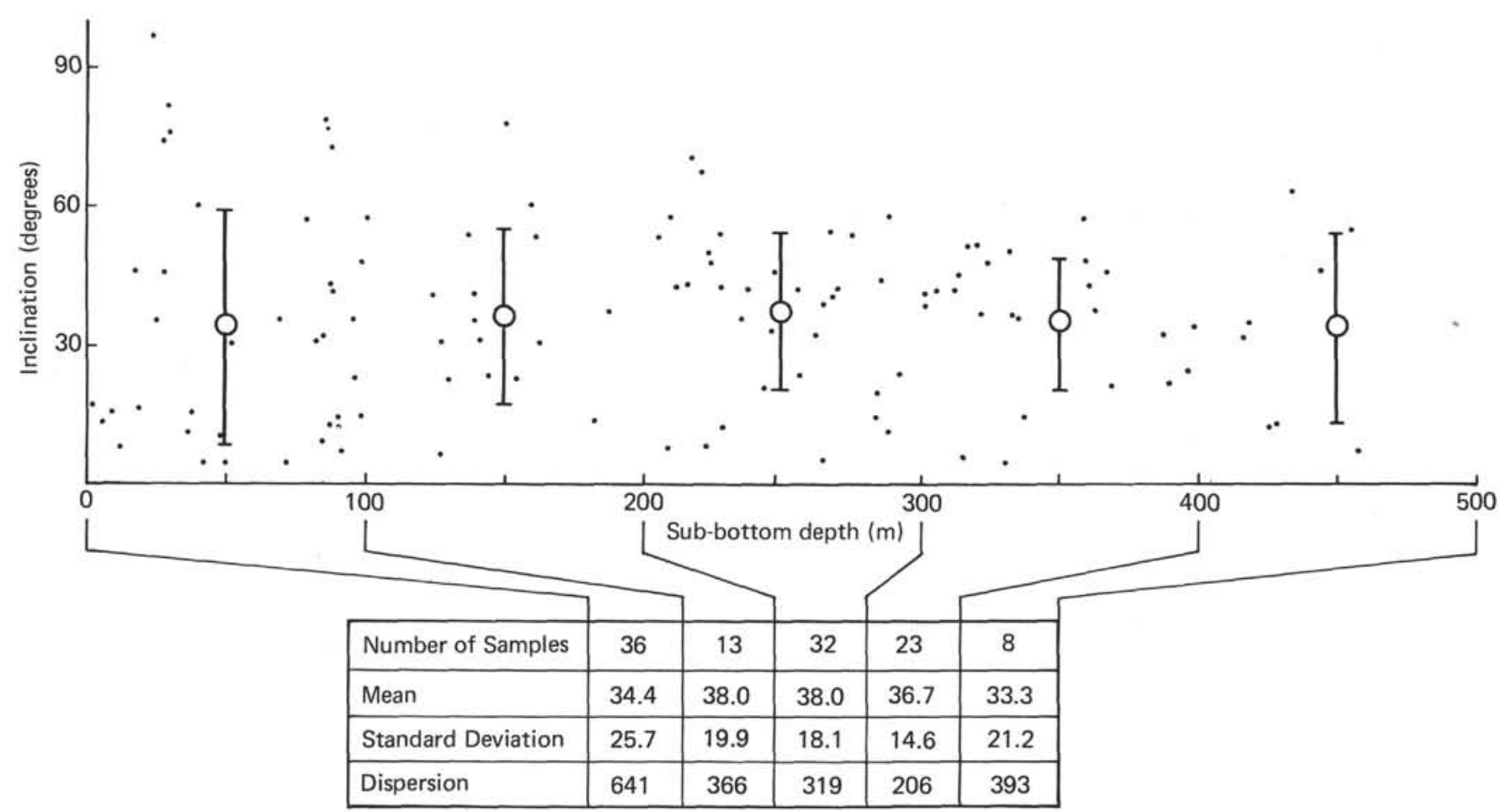

Figure 11. Absolute values of inclination of NRM versus sub-bottom depth of sedimentary layers. Open circles are mean values of inclination taken every 100 meters. Vertical bars represent standard deviations.

Site 443 were probably formed during a time not shorter than $0.2 \mathrm{~m} . \mathrm{y}$.

\section{PHYSICAL PROPERTIES}

Sediments and basalts recovered from Site 443 provided samples useful for continued study of relationships noted in the Site 442 report. Sonic velocity, thermal conductivity, density, and porosity were determined for basalts and sediments (Tables 10 and 11). Water content was measured for sediments (Table 10), and special 2-minute GRAPE counts were run on basalts to provide estimates of porosity and density (Table 12). Grain densities assumed in calculations of GRAPE densities and porosities were $3.031 \mathrm{~g} / \mathrm{cm}^{3}$ for samples taken above Core 55, $2.988 \mathrm{~g} / \mathrm{cm}^{3}$ for Cores 55 through 58 , and $2.960 \mathrm{~g} / \mathrm{cm}^{3}$ for samples taken below Core 58 .

Sonic velocities in sediments show little variation with depth (Figure 14). The average velocity is 1.57 $\mathrm{km} / \mathrm{s}$, with a range of 1.50 to $1.76 \mathrm{~km} / \mathrm{s}$. The only significant variation in velocity occurred within unit $\mathrm{V}$, where sonic velocities reach a maximum, reflecting the lithologic variability of this unit (see lithology section). Densities for the sediments also show little variation with depth (Figure 14), ranging from 1.38 to $1.59 \mathrm{~g} / \mathrm{cm}^{3}$ and averaging $1.49 \mathrm{~g} / \mathrm{cm}^{3}$. The density of the claystone in Core 49, Section 2, is $1.75 \mathrm{~g} / \mathrm{cm}^{3}$, much higher than that of the other recovered sediments.

Thermal conductivity for Hole 443 sediments also shows little variation with depth (Figure 14), with the exception of unit III, which varies from clayey nannofossil ooze to mud (see lithology section). No consistent relationship between thermal conductivity and water content (Table 10) was observed.
Shear strength of the sediments increases with depth in the upper 165 meters of the site (Figure 15). The correlation coefficient of the fit is poor. A better fit may be obtained by using two different linear fits. Shear strength increases most dramatically in the lower part of unit Ila. Drilling breccias were recovered in the lowermost part of unit IIa and in unit IIb. There are no shearstrength data for this unit, because of the disruption of the sediment. The recovery of drilling breccia below 165 meters is consistent with the findings from earlier experiments discussed in the physical-properties section of the Site 442 report.

The excellent recovery of basalts from Hole 443 provided an opportunity to study the variation of physical properties with depth in a series of different units. Sonic velocities for basalts at atmospheric pressure average $5.32 \mathrm{~km} / \mathrm{s}$ and range from 3.82 to $5.91 \mathrm{~km} / \mathrm{s}$. Wet-bulk densities of Hole 443 basalts average $2.81 \mathrm{~g} / \mathrm{cm}^{3}$ and range from 2.46 to $3.10 \mathrm{~g} / \mathrm{cm}^{3}$.

In general, the average sonic velocities and densities for Hole 443 basalts are higher than those for Site 442 . The range of values is also larger. Velocities and densities for basalts from Cores 55 through 58, however, are approximtely equal to those of Site 442 basalts. Figure 16 shows the variation of sonic velocities with depth. The lower sonic velocities for Cores 55 through 58 form a distinctive cluster between 502 and 525 meters. Similar relationships are evident for basalt wetbulk densities (Figure 16) and thermal conductivity (Figure 17). The average velocities, wet-bulk densities, grain densities, thermal conductivities, and porosities for each depth group are presented in Table 13. The boundaries at 501.78 and 525 meters correspond to 
TABLE 8

Paleomagnetism of Basalts, Hole 443

\begin{tabular}{|c|c|c|c|c|c|c|c|c|c|}
\hline $\begin{array}{c}\text { Sample } \\
\text { (interval in } \mathrm{cm} \text { ) }\end{array}$ & $\begin{array}{c}\text { Sub- } \\
\text { bottom } \\
\text { Depth } \\
(\mathrm{m})\end{array}$ & $\begin{array}{l}\text { Flow } \\
\text { Unit }\end{array}$ & $\begin{array}{l}J_{\mathrm{NRM}} \\
\left(10^{-5}\right. \\
\text { gauss) } \\
\end{array}$ & $\begin{array}{c}\text { Inclina- } \\
\text { tion } \\
\text { NRM }\end{array}$ & $\begin{array}{c}\text { Inclina- } \\
\text { tion } \\
\text { AFD }\end{array}$ & $\begin{array}{l}\text { MDF } \\
(\mathrm{oe})\end{array}$ & $\begin{array}{c}X_{\text {in }} \\
\left(10^{-5}\right. \\
\text { gauss/oe }) \\
\end{array}$ & $Q_{n}^{\prime}$ & Remarks \\
\hline $\begin{array}{c}443-49-3,101-103 \\
49-3,137-139 \\
49-4,40-42 \\
49-4,102-104 \\
50-1,85-87\end{array}$ & $\begin{array}{l}457.52 \\
457.88 \\
458.41 \\
459.03 \\
463.86\end{array}$ & $\begin{array}{l}\text { A } \\
\text { A } \\
\text { A } \\
\text { A } \\
\text { A }\end{array}$ & $\begin{array}{r}674.7 \\
1034.6 \\
704.2 \\
476.7 \\
528.5\end{array}$ & $\begin{array}{l}-29.1 \\
-29.6 \\
-31.8 \\
-25.8 \\
-28.7\end{array}$ & $\begin{array}{l}-28.2 \\
-32.5 \\
-31.7 \\
-29.6 \\
-\end{array}$ & $\begin{array}{r}110 \\
110 \\
80 \\
70 \\
-\end{array}$ & $\begin{array}{r}11.00 \\
7.61 \\
8.60 \\
8.96 \\
6.56\end{array}$ & $\begin{array}{l}141.6 \\
313.8 \\
189.0 \\
122.8 \\
185.9\end{array}$ & $\begin{array}{l}150 \mathrm{oe} \\
150 \mathrm{oe} \\
100 \mathrm{oe} \\
100 \mathrm{oe}\end{array}$ \\
\hline $\begin{array}{l}50-2,30-32 \\
50-4,02-04 \\
51-1,09-11 \\
52-1,33-35 \\
52-2,120-122\end{array}$ & $\begin{array}{l}464.81 \\
467.53 \\
472.60 \\
482.34 \\
484.71\end{array}$ & $\begin{array}{l}\text { A } \\
\text { A } \\
\text { B } \\
\text { B } \\
\text { B }\end{array}$ & $\begin{array}{l}585.8 \\
555.8 \\
256.3 \\
182.3 \\
449.2\end{array}$ & $\begin{array}{r}-31.3 \\
-32.7 \\
42.2 \\
40.5 \\
31.6\end{array}$ & $\begin{array}{r}-29.9 \\
-33.6 \\
- \\
41.2 \\
46.6\end{array}$ & $\begin{array}{r}75 \\
75 \\
- \\
390 \\
85\end{array}$ & $\begin{array}{l}6.34 \\
7.91 \\
0.70 \\
0.85 \\
7.89\end{array}$ & $\begin{array}{l}213.2 \\
162.2 \\
845.0 \\
495.0 \\
131.4\end{array}$ & $\begin{array}{l}100 \mathrm{oe} \\
100 \mathrm{oe} \\
400 \mathrm{oe} \\
100 \mathrm{oe}\end{array}$ \\
\hline $\begin{array}{l}52-4,21-23 \\
53-1,07-09 \\
53-2,12-14 \\
53-3,86-88 \\
54-1,54-56\end{array}$ & $\begin{array}{l}486.72 \\
491.58 \\
493.13 \\
495.37 \\
501.55\end{array}$ & $\begin{array}{l}\text { B } \\
\text { B } \\
\text { B } \\
\text { B } \\
\text { B }\end{array}$ & $\begin{array}{l}557.7 \\
603.7 \\
342.4 \\
584.1 \\
411.9\end{array}$ & $\begin{array}{l}32.8 \\
31.6 \\
42.8 \\
39.0 \\
41.8\end{array}$ & $\begin{array}{l}39.5 \\
39.6 \\
42.5 \\
40.5 \\
39.3\end{array}$ & $\begin{array}{r}105 \\
80 \\
190 \\
100 \\
490\end{array}$ & $\begin{array}{l}3.95 \\
5.74 \\
1.10 \\
3.51 \\
0.57\end{array}$ & $\begin{array}{r}325.8 \\
242.7 \\
718.4 \\
384.0 \\
1667.7\end{array}$ & $\begin{array}{l}150 \mathrm{oe} \\
100 \mathrm{oe} \\
200 \mathrm{oe} \\
150 \mathrm{oe} \\
500 \mathrm{oe}\end{array}$ \\
\hline $\begin{array}{l}54-2,54-56 \\
54-2,138-140 \\
54-3,125-127 \\
54-4,146-148 \\
54-5,146-148\end{array}$ & $\begin{array}{l}503.05 \\
503.89 \\
505.26 \\
506.95 \\
508.47\end{array}$ & $\begin{array}{l}\text { B } \\
\text { B } \\
\text { B } \\
\text { B } \\
\text { B }\end{array}$ & $\begin{array}{l}733.4 \\
398.1 \\
179.7 \\
316.6 \\
273.8\end{array}$ & $\begin{array}{l}38.9 \\
26.2 \\
38.5 \\
45.7 \\
43.5\end{array}$ & $\begin{array}{r}41.8 \\
42.3 \\
- \\
43.5 \\
40.3\end{array}$ & $\begin{array}{r}90 \\
75 \\
- \\
100 \\
400\end{array}$ & $\begin{array}{l}6.52 \\
8.96 \\
1.07 \\
8.68 \\
0.88\end{array}$ & $\begin{array}{r}259.6 \\
102.5 \\
386.9 \\
84.2 \\
718.0\end{array}$ & $\begin{array}{l}100 \mathrm{oe} \\
100 \mathrm{oe} \\
150 \mathrm{oe} \\
450 \mathrm{oe}\end{array}$ \\
\hline $\begin{array}{l}54-6,14-16 \\
54-7,76-78 \\
54-7,138-140 \\
55-1,99-101 \\
55-2,60-62\end{array}$ & $\begin{array}{l}508.65 \\
510.77 \\
511.39 \\
511.50 \\
512.61\end{array}$ & $\begin{array}{l}\text { B } \\
\text { B } \\
\text { C } \\
\text { C } \\
\text { C }\end{array}$ & $\begin{array}{r}1328.3 \\
611.7 \\
731.7 \\
208.2 \\
174.9\end{array}$ & $\begin{array}{l}41.9 \\
37.4 \\
63.5 \\
71.5 \\
72.7\end{array}$ & $\begin{array}{l}46.1 \\
41.5 \\
62.8 \\
72.4 \\
74.5\end{array}$ & $\begin{array}{r}80 \\
80 \\
470 \\
300 \\
310\end{array}$ & $\begin{array}{l}4.21 \\
6.64 \\
1.20 \\
2.31 \\
1.21\end{array}$ & $\begin{array}{r}728.1 \\
212.6 \\
1407.2 \\
208.0 \\
333.6\end{array}$ & $\begin{array}{l}100 \mathrm{oe} \\
100 \mathrm{oe} \\
500 \mathrm{oe} \\
350 \mathrm{oe} \\
350 \mathrm{oe}\end{array}$ \\
\hline $\begin{array}{l}56-1,117-119 \\
56-2,100-102 \\
56-3,120-122 \\
57-1,06-08 \\
57-1,134-136\end{array}$ & $\begin{array}{l}521.16 \\
522.51 \\
524.21 \\
529.57 \\
530.85\end{array}$ & $\begin{array}{l}\mathrm{C} \\
\mathrm{C} \\
\mathrm{C} \\
\mathrm{C} \\
\mathrm{C}\end{array}$ & $\begin{array}{r}709.6 \\
110.1 \\
53.3 \\
16.5 \\
65.8\end{array}$ & $\begin{array}{l}60.0 \\
60.2 \\
58.1 \\
51.8 \\
65.9\end{array}$ & $\begin{array}{c}59.9 \\
58.2 \\
63.9 \\
53.2 \\
-\end{array}$ & $\begin{array}{l}210 \\
310 \\
420 \\
280 \\
-\end{array}$ & $\begin{array}{l}1.61 \\
1.29 \\
1.17 \\
1.20 \\
0.94\end{array}$ & $\begin{array}{r}1017.2 \\
197.0 \\
105.1 \\
31.7 \\
161.5\end{array}$ & $\begin{array}{l}250 \text { oe } \\
350 \text { oe } \\
450 \text { oe } \\
300 \text { oe }\end{array}$ \\
\hline $\begin{array}{l}57-2,125-127 \\
58-1,61-63 \\
58-2,67-69 \\
58-3,34-36 \\
58-3,121-123\end{array}$ & $\begin{array}{l}532.26 \\
539.62 \\
541.19 \\
542.35 \\
543.22\end{array}$ & $\begin{array}{l}\mathrm{C} \\
\mathrm{C} \\
\mathrm{C} \\
\mathrm{C} \\
\mathrm{C}\end{array}$ & $\begin{array}{l}209.2 \\
306.2 \\
254.4 \\
232.7 \\
440.4\end{array}$ & $\begin{array}{l}53.1 \\
65.5 \\
72.2 \\
77.2 \\
69.6\end{array}$ & $\begin{array}{l}54.0 \\
64.6 \\
72.8 \\
76.1 \\
73.6\end{array}$ & $\begin{array}{r}180 \\
120 \\
140 \\
95 \\
80\end{array}$ & $\begin{array}{l}1.15 \\
3.86 \\
5.54 \\
5.10 \\
9.47\end{array}$ & $\begin{array}{l}419.9 \\
183.1 \\
106.0 \\
105.3 \\
107.3\end{array}$ & $\begin{array}{l}200 \mathrm{oe} \\
150 \mathrm{oe} \\
150 \mathrm{oe} \\
100 \mathrm{oe} \\
100 \mathrm{oe}\end{array}$ \\
\hline $\begin{array}{l}58-4,06-08 \\
58-4,34-36 \\
58-5,69-71 \\
59-1,12-14 \\
59-2,15-17\end{array}$ & $\begin{array}{l}543.57 \\
543.85 \\
544.20 \\
548.63 \\
550.16\end{array}$ & $\begin{array}{l}\text { C } \\
\text { C } \\
\text { D } \\
\text { D }\end{array}$ & $\begin{array}{r}282.6 \\
273.0 \\
41.2 \\
72.0 \\
75.2\end{array}$ & $\begin{array}{r}69.4 \\
71.0 \\
-51.9 \\
53.8 \\
35.4\end{array}$ & $\begin{array}{r}71.9 \\
-50.2 \\
46.1 \\
52.9\end{array}$ & $\begin{array}{r}- \\
150 \\
>600 \\
140 \\
60\end{array}$ & $\begin{array}{l}6.75 \\
9.16 \\
0.42 \\
1.52 \\
2.83\end{array}$ & $\begin{array}{r}96.6 \\
68.8 \\
226.4 \\
109.3 \\
61.3\end{array}$ & $\begin{array}{l}200 \text { oe } \\
500 \text { oe } \\
150 \text { oe } \\
100 \text { oe }\end{array}$ \\
\hline $\begin{array}{l}59-2,106-108 \\
59-3,12-14 \\
59-4,142-144 \\
60-1,15-17 \\
60-1,111-113\end{array}$ & $\begin{array}{l}551.07 \\
551.63 \\
554.43 \\
558.16 \\
559.12\end{array}$ & $\begin{array}{l}D \\
D \\
D \\
D \\
D\end{array}$ & $\begin{array}{l}80.2 \\
44.2 \\
37.9 \\
75.1 \\
95.6\end{array}$ & $\begin{array}{l}-47.0 \\
-6.5 \\
38.7 \\
62.0 \\
43.9\end{array}$ & $\begin{array}{r}-51.1 \\
-53.6 \\
52.5 \\
49.5 \\
51.0\end{array}$ & $\begin{array}{l}190 \\
120 \\
110 \\
110 \\
100\end{array}$ & $\begin{array}{l}3.18 \\
3.75 \\
2.86 \\
7.54 \\
7.35\end{array}$ & $\begin{array}{l}58.2 \\
27.2 \\
30.6 \\
23.0 \\
30.0\end{array}$ & $\begin{array}{l}200 \text { oe } \\
150 \text { oe } \\
150 \text { oe } \\
150 \text { oe } \\
150 \text { oe }\end{array}$ \\
\hline $\begin{array}{l}60-2,110-112 \\
60-3,74-76 \\
60-4,04-06 \\
60-4,125-127 \\
61-1,89-91\end{array}$ & $\begin{array}{l}560.61 \\
561.75 \\
562.55 \\
563.76 \\
568.40\end{array}$ & $\begin{array}{l}\text { D } \\
\text { D } \\
\text { D } \\
\text { D } \\
\text { D }\end{array}$ & $\begin{array}{l}97.8 \\
82.5 \\
72.2 \\
31.9 \\
78.8\end{array}$ & $\begin{array}{l}36.7 \\
50.7 \\
31.4 \\
68.3 \\
49.5\end{array}$ & $\begin{array}{l}47.3 \\
51.5 \\
45.9 \\
58.7 \\
54.2\end{array}$ & $\begin{array}{l}70 \\
40 \\
60 \\
90 \\
60\end{array}$ & $\begin{array}{l}7.66 \\
7.15 \\
8.28 \\
8.65 \\
6.50\end{array}$ & $\begin{array}{c}29.5 \\
26.6 \\
20.1 \\
8.51 \\
30.0\end{array}$ & $\begin{array}{r}100 \mathrm{oe} \\
50 \mathrm{oe} \\
100 \mathrm{oe} \\
100 \mathrm{oe} \\
100 \mathrm{oe}\end{array}$ \\
\hline $\begin{array}{l}61-2,103-105 \\
61-4,106-108 \\
62-1,90-92 \\
62-2,29-31 \\
62-4,62-64\end{array}$ & $\begin{array}{l}570.04 \\
573.07 \\
577.91 \\
578.80 \\
582.13\end{array}$ & $\begin{array}{l}D \\
D \\
D \\
D \\
D\end{array}$ & $\begin{array}{r}113.9 \\
136.3 \\
82.8 \\
35.6 \\
50.2\end{array}$ & $\begin{array}{l}57.2 \\
48.6 \\
50.9 \\
43.9 \\
46.2\end{array}$ & $\begin{array}{l}56.4 \\
49.8 \\
50.7 \\
50.5 \\
42.3\end{array}$ & $\begin{array}{l}115 \\
180 \\
195 \\
170 \\
320\end{array}$ & $\begin{array}{l}1.79 \\
1.62 \\
2.61 \\
1.47 \\
0.66\end{array}$ & $\begin{array}{r}146.8 \\
194.2 \\
88.5 \\
55.9 \\
175.6\end{array}$ & $\begin{array}{l}150 \text { oe } \\
200 \text { oe } \\
200 \text { oe } \\
200 \text { oe } \\
350 \text { oe }\end{array}$ \\
\hline $\begin{array}{l}63-1,10-12 \\
63-2,71-73 \\
63-4,99-101 \\
63-5,128-130 \\
63-5,137-139\end{array}$ & $\begin{array}{l}586.61 \\
588.72 \\
592.00 \\
593.79 \\
593.89\end{array}$ & $\begin{array}{l}\mathrm{D} \\
\mathrm{D} \\
\mathrm{D} \\
\mathrm{D} \\
\mathrm{D}\end{array}$ & $\begin{array}{r}27.5 \\
50.8 \\
127.4 \\
27.6 \\
78.5\end{array}$ & $\begin{array}{l}43.5 \\
47.6 \\
68.2 \\
40.0 \\
43.7\end{array}$ & $\begin{array}{l}36.4 \\
47.1 \\
54.7 \\
47.4 \\
52.3\end{array}$ & $\begin{array}{l}240 \\
390 \\
105 \\
310 \\
170\end{array}$ & $\begin{array}{l}1.06 \\
1.70 \\
5.71 \\
0.93 \\
7.59\end{array}$ & $\begin{array}{l}58.9 \\
69.0 \\
56.9 \\
68.5 \\
23.9\end{array}$ & $\begin{array}{l}250 \text { oe } \\
400 \text { oe } \\
150 \text { oe } \\
350 \text { oe } \\
200 \text { oe }\end{array}$ \\
\hline $\begin{array}{l}63-8,84-86 \\
64-2,16-18 \\
64-3,20-22\end{array}$ & $\begin{array}{l}596.85 \\
597.67 \\
599.21\end{array}$ & $\begin{array}{l}\mathrm{D} \\
\mathrm{D} \\
\mathrm{D}\end{array}$ & $\begin{array}{l}79.1 \\
74.0 \\
79.1\end{array}$ & $\begin{array}{r}24.0 \\
7.9 \\
27.2\end{array}$ & $\begin{array}{l}53.9 \\
49.3 \\
50.8\end{array}$ & $\begin{array}{l}50 \\
- \\
-\end{array}$ & $\begin{array}{l}8.97 \\
6.66 \\
7.76\end{array}$ & $\begin{array}{l}20.4 \\
25.6 \\
23.5\end{array}$ & $\begin{array}{l}100 \mathrm{oe} \\
100 \mathrm{oe} \\
100 \mathrm{oe}\end{array}$ \\
\hline
\end{tabular}

${ }^{\mathrm{a}} \mathrm{MDF}$ is the median destructive field (of AF demagnetization) at which the remanent magnetism of a specimen decreases to $50 \%$ of its initial value; $X_{\text {in }}$ is the initial susceptibility of a specimen; $Q_{n}^{\prime}$ is the Koenigsberger ratio of NRM; peak field strength listed in remarks column is that at which inclination of AFD remanent magnetization was taken; for other notations refer to Table 7 . 


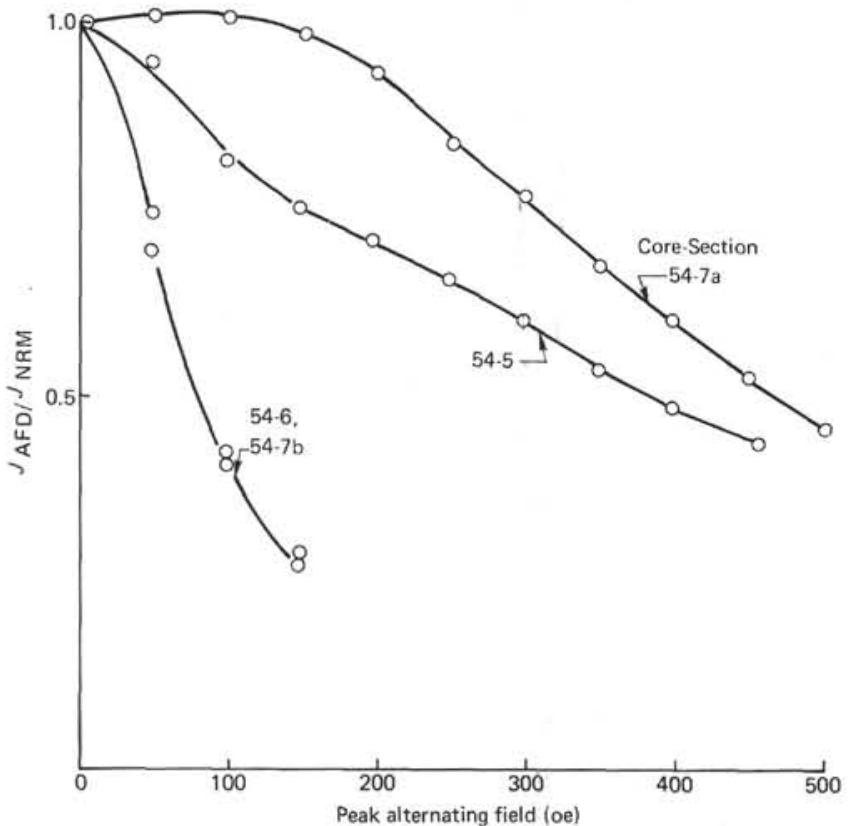

Figure 12. Stability of NRM with respect to AF demagnetization. The horizontal axis represents peak alternating magnetic field decreasing to zero at a constant rate. $\mathrm{J}_{N R M}$ and $\mathrm{J}_{A F D}$ are intensities of NRM and $A F$ demagnetized remanent magnetization of a specimen. All samples are normally magnetized.

boundaries established from shipboard paleomagnetism studies (see paleomagnetism section). The magneticpolarity reversal between Cores 50 and 51 may also correlate with a change in the physical properties (Figure 16). Physical-property boundaries also correlate with major lithologic boundaries (see igneous-petrology section and Figure 16).

Physical properties of basalts from Site 443 exhibit the same dependence on porosity as did basalts from Site 442 (see physical-properties section, Site 442 report). Figure 18 shows the relationship between wetbulk density and porosity for these basalts, with the theoretical relation between wet-bulk density and porosity superimposed. The close agreement between the shipboard data and the theoretical lines indicates that porosity, not mineral alteration, controls the measured values of wet-bulk density. This is corroborated by the high average grain density $\left(2.997 \mathrm{~g} / \mathrm{cm}^{3}\right)$ of the Site 442 basalts. Sonic velocity is linearly related to wet-bulk density (Figure 19), with a correlation coefficient of 0.91 , a slope of 3.62 , and an intercept of -5.04 . The velocity-density relationship, however, is simply the manifestation of the dependence of velocity on porosity, as illustrated in Figure 20 . The correlation coefficient for this inverse relationship is -0.90 . Thermal conductivity of basalts, as expected, also exhibits an inverse relationship with porosity (Figure 21 ), with a correlation coefficient of -0.90 .

The variation of sonic velocity, wet-bulk density, and thermal conductivity with depth observed for Site 443 basalts can be understood best as a variation of porosity with depth. Porosity, in this case, can be correlated
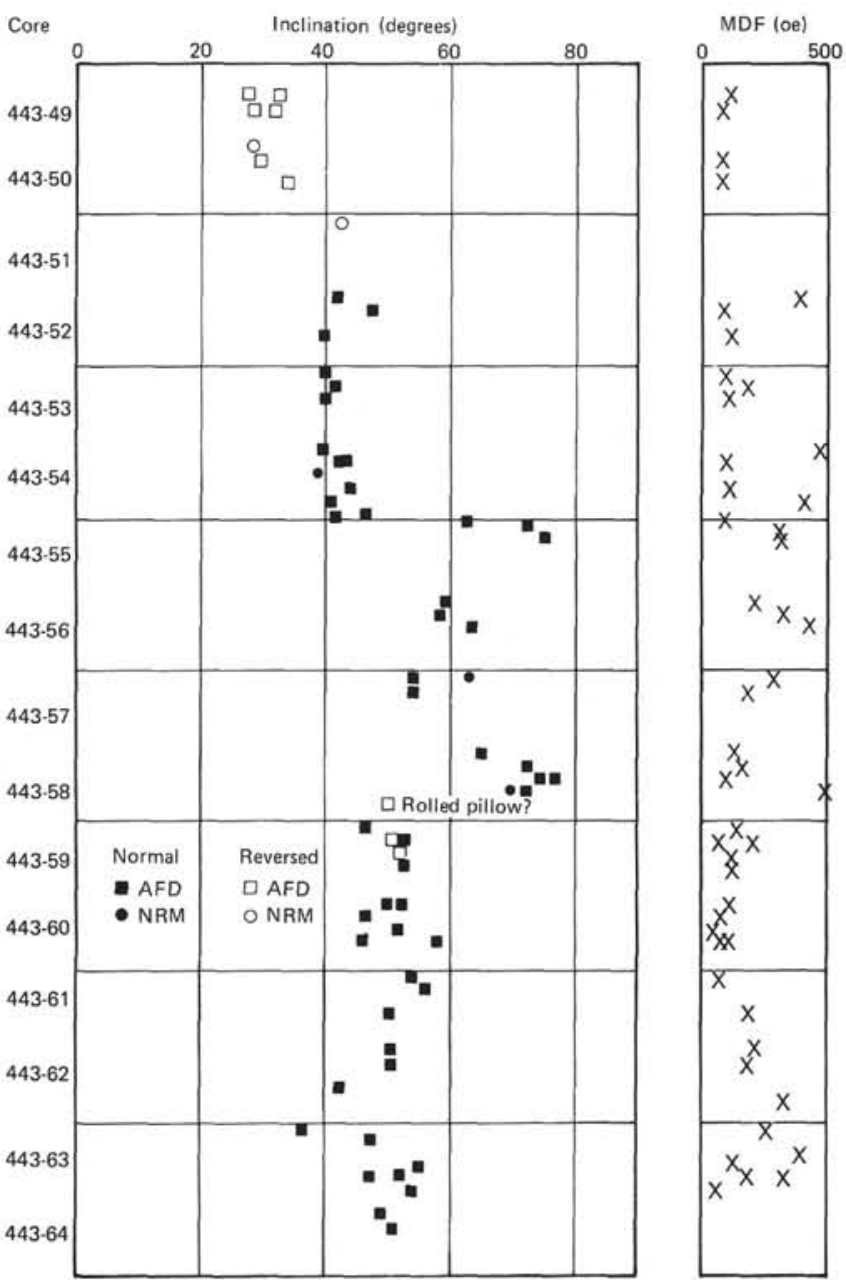

Figure 13. Inclination of stable remanent magnetization and median destructive field (MDF) of basalts, plotted against position in cores.

TABLE 9

Statistics of Paleomagnetism Results for Basalt Samples of Site 443

\begin{tabular}{lcccc}
\hline $\begin{array}{l}\text { Population } \\
\text { Cores }\end{array}$ & A & B & C & D \\
\hline $\begin{array}{l}\text { Number of } \\
\text { Samples }\end{array}$ & $7(1)$ & $15(2)$ & $15(2)$ & 26 \\
$\begin{array}{l}\text { Mean } \\
\text { Standard }\end{array}$ & 30.6 & 41.7 & 66.2 & 50.2 \\
$\begin{array}{l}\text { Deviation } \\
\text { Dispersion }\end{array}$ & 2.0 & 2.3 & 7.5 & 4.5 \\
\hline
\end{tabular}

\footnotetext{
${ }^{a}$ Number of NRM data in parentheses; one of the samples of population D probably was taken from a pillow basalt rolled after cooling and fixing the NRM.
}

directly with the wide range of vesicularity of Site 443 basalts (see igneous-petrology section). An implication of Figure 16 is that the cooling units of Site 443 exhibit significant differences in vesicularity, unit 2 being the most vesicular unit, unit 1 the least, and units 3,4 , and 5 being of intermediate vesicularity. The differences in 
vesicularity, reflected in the physical properties, must be related to basalt petrogenesis, and may be related to the volatile content of the original magmas.

The seismic structure (Figure 16) of the basement of Site 443 is different from that proposed for the top of layer $2 \mathrm{~A}$ by other workers and may be characteristic of this portion of the Shikoku Basin. Velocities of the basalts are high, with the exception of the zone of high vesicularity. Recovery of basalts from this hole was very good, greater than 70 per cent, and only a small amount of sedimentary rock was recovered. This suggests that sedimentary interbeds are uncommon and probably of insufficient volume to lower the average sonic velocity of layer $2 \mathrm{~A}$ at this site. The variable vesicularity in the basalts from Hole 443 produces high-velocity layers with thin low-velocity layers between them. If this stratigraphic relationship continues with depth, and if the seismic waves "sensed" the porosity, a complex acoustic stratigraphy would be produced. The presence of thin low-velocity layers could cause errors in velocity and depth calculations from seismic-refraction profiles. The low velocity for layer $2 \mathrm{~A}$ at this site may be caused by the combined effect of thin low-velocity layers, extensively fractured basalts (see igneous-petrology section), and intervals of glassy pillow rinds. Furthermore, if large-scale formation porosity is responsible for the low velocity, the formation porosity must exceed 30 per cent (Figure 20).

\section{CORRELATION OF GEOPHYSICAL DATA WITH DRILLING RESULTS}

\section{Introduction}

Site 443 is about 2 nautical miles southeast of shot point 950, line 2-1 of the S/S Kaiyo-Maru seismicreflection profiles (Figure 1). The site is on the western shoulder of a positive magnetic anomaly with moderate amplitude (170 gammas peak to trough) which has been tentatively identified as anomaly $6 \mathrm{~A}$ (20 to $21 \mathrm{~m} . \mathrm{y}$.), assuming symmetrical spreading of the basin from an axis (magnetic anomaly 5) at the geographical center of the basin.

An earlier sonobuoy measurement made along a NNW-SSE line nearly on the present site (Murauchi and Asanuma, pers. comm.) has slightly less quality than that done by the Challenger at Site 442 , because of rough seas during the site survey. A sonobuoy survey was not made when the Challenger left Site 443 because of bad weather. In spite of these difficulties, seismic data can be correlated rather well with drilling results.

\section{Sonic Velocity and Sub-Bottom Depth}

Reflection profiles taken underway when approaching and leaving the site show a layering of semitransparent sediment with two-way normal time of about 0.58 seconds overlying the acoustic basement. Shipboard measurement of sonic velocity indicated that $V_{\mathrm{P}}$ of sediment recovered is about $1.55 \mathrm{~km} / \mathrm{s}$ on the average, throughout the cores from this site. Thickness of sediment thus estimated is 450 meters, which is in agreement with the depth of the first recovery of basalt, 457 meters.

A previous sonobuoy survey indicated that sediment is underlain by layer $2 \mathrm{~A}$ basalt, with a thickness of 540 meters and $V_{\mathrm{P}}$ of $3.2 \mathrm{~km} / \mathrm{s}$, overlying layer $2 \mathrm{~B}$ with thickness of 600 meters and $V_{\mathrm{P}}$ of $4.56 \mathrm{~km} / \mathrm{s}$. $V_{\mathrm{P}}$ of basalts recovered at this site ranges from 3.8 to $5.9 \mathrm{~km} / \mathrm{s}$ (about $5.2 \mathrm{~km} / \mathrm{s}$ on the average), appreciably larger than $V_{\mathrm{P}}$ of basalts taken at Site $442(4.6 \mathrm{~km} / \mathrm{s})$. This difference in the measured sonic velocity at two sites seems to be sufficiently large to explain the difference in $V_{\mathrm{p}}$ of layer $2 \mathrm{~A}$ obtained by sonobuoy. However, a much higher percentage of recovery of basalts at this site $(67 \%)$ compared to that at Site $442(24 \%)$ indicates that interlayering of sediments is substantially less in the uppermost 116 meters of basalt penetrated at this site than at Site 442. It seems therefore likely that local faulting or fractures which are undetectable by vertical drilling reduce the bulk seismic velocity observed by sonobuoy survey.

\section{Magnetic Anomaly, Paleomagnetism, and Paleontological Age}

The vertical alteration of normal and reversed polarities of natural remanent magnetization in rocks recovered at this site indicates that the superficial layer alone is not primarily the source of the magnetic anomaly observed above the sea floor. The relatively small amplitude of the anomaly around this site implies that the original magnetic basement, supposedly formed by a sea-floor-spreading mechanism, is thinner than that at Site 442 , although it still is not known which layer is responsible for the observed anomalies.

The paleontological age of sediment overlying the uppermost massive basalt unit is 14 to $15 \mathrm{~m} . \mathrm{y}$., which is appreciably less than the oldest sediment age of Site 442 (18 to $21 \mathrm{~m} . \mathrm{y}$.). It is even less than the age of sediment imediately above the massive basalt flow first recovered at Site 442 (15-17 m.y.). This tempts us to reconsider the plausibility of the single-limb spreading model postulated by Watts and Weissel (1975) and disregarded afterward. Coincidence of their magnetism ages with the present paleontological age is good, as seen in Figure 22.

However, off-ridge volcanism occurring a few million years after the formation of the primary crust of this site also could account for the age discrepancy, if off-ridge volcanism occurred between 18 and 21 and 14 and $15 \mathrm{~m} . \mathrm{y}$. at Site 443, after which sedimentation dominated. We already have evidence of a hiatus in lavaflow accumulation at Site 442, which suggests the possibility of frequent off-ridge volcanism in the Shikoku Basin. A similar hiatus was found in the Reykjanes Ridge at DSDP Site 407 (Luyendyk, Cann, et al., 1979). It must be noted that the postulated rate of spreading of the Shikoku Basin (2-4 cm/yr) is very similar to that for the Reykjanes Ridge. 
TABLE 10

Summary of Physical Properties of Sediments, Hole 443

\begin{tabular}{|c|c|c|c|c|c|c|c|}
\hline $\begin{array}{c}\text { Sample } \\
\text { (interval in } \mathrm{cm} \text { ) }\end{array}$ & Lithology & $\begin{array}{l}\text { Sonic } \\
\text { Velocity } \\
(\mathrm{km} / \mathrm{s})\end{array}$ & $\begin{array}{c}\text { Thermal } \\
\text { Conductivity } \\
\text { (mcal/cm-s- }{ }^{\circ} \mathrm{C} \text { ) }\end{array}$ & $\begin{array}{c}\text { Shear } \\
\text { Strength } \\
\left(\times 10^{-5} \text { dynes } / \mathrm{cm}^{2}\right)\end{array}$ & $\begin{array}{l}\text { Wet-Bulk } \\
\text { Density } \\
\left(\mathrm{g} / \mathrm{cm}^{3}\right)\end{array}$ & $\begin{array}{l}\text { Porosity } \\
\text { (\%) }\end{array}$ & $\begin{array}{c}\text { Water } \\
\text { Content } \\
(\%)\end{array}$ \\
\hline $443-1-4,76-80$ & mud & - & - & 0.29 & 1.42 & 76.54 & 55.12 \\
\hline $1-4,111-114$ & $"$ & - & - & 0.48 & - & - & - \\
\hline $2-1,80-83$ & " & 1.934 & - & 0.67 & 1.38 & 80.50 & 59.59 \\
\hline $2-3,50-53$ & $"$ & - & - & 0.38 & - & - & - \\
\hline $2-4,0-1$ & " & - & - & - & 1.46 & 72.25 & 50.66 \\
\hline $3-1,20-23$ & " & - & - & 0.29 & - & - & - \\
\hline $3-2,20-23$ & " & - & - & 0.48 & 1.53 & 73.06 & 48.86 \\
\hline $3-2,69-72$ & $"$ & - & - & 0.86 & - & - & - \\
\hline $3-3,103-106$ & " & - & _- & 0.29 & - & - & - \\
\hline $3-4,131-134$ & $"$ & - & - & 0.29 & - & - & - \\
\hline $3-5,40-54$ & $"$ & 1.518 & 2.494 & 0.29 & - & - & - \\
\hline $3-6,62-65$ & $"$ & - & - & 0.19 & - & - & - \\
\hline $4-1,81-83$ & $"$ & - & - & 0.29 & - & - & - \\
\hline $4-2,100-110$ & $"$ & 1.505 & 2.425 & 0.86 & 1.45 & 72.72 & 51.52 \\
\hline $4-3,61-64$ & $"$ & - & - & 0.29 & - & - & - \\
\hline $5-1,22-32$ & $"$ & 1.506 & 2.608 & 0.20 & - & - & - \\
\hline $5-2,13-16$ & $"$ & - & - & 0.29 & - & - & - \\
\hline $5-3,110-113$ & nannofossil mud & - & - & 0.20 & 1.46 & 77.21 & 54.32 \\
\hline $5-4,45-48$ & mud & - & - & 0.19 & - & - & - \\
\hline $6-2,75-78$ & nannofossil mud & - & - & 1.05 & - & - & - \\
\hline $6-2,150-170$ & $"$ & - & - & - & 1.42 & 75.93 & 54.87 \\
\hline $6-3,75-78$ & $"$ & - & - & 0.50 & - & - & - \\
\hline $6-4,75-85$ & $"$ & 1.539 & 2.036 & 2.49 & 1.49 & 69.87 & 47.89 \\
\hline $6-5,75-78$ & $"$ & - & - & 1.24 & - & - & - \\
\hline $7-7,3-7$ & $"$ & - & - & 0.50 & 1.49 & 69.29 & 47.67 \\
\hline $8-4,57-67$ & $"$ & 1.509 & 2.564 & 0.57 & 1.52 & 74.54 & 50.23 \\
\hline $9-4,40-50$ & $"$ & 1.503 & 2.514 & - & - & - & - \\
\hline $9-5,18-28$ & $"$ & 1.585 & 2.578 & 0.19 & 1.47 & 76.09 & 53.12 \\
\hline $10-4,35-38$ & $"$ & - & - & 0.77 & - & - & - \\
\hline $10-6,27-37$ & $"$ & 1.507 & 2.583 & 0.86 & 1.52 & 72.56 & 49.02 \\
\hline $11-4,93-96$ & " & - & - & 1.72 & - & - & - \\
\hline $11-6,50-60$ & $"$ & 1.515 & 2.433 & 1.34 & 1.48 & 71.84 & 49.61 \\
\hline $14-4,90-93$ & mud & - & - & 0.67 & - & - & - \\
\hline $14-5,79-93$ & $"$ & 1.522 & 2.061 & 2.20 & 1.44 & 69.11 & 49.09 \\
\hline $14-5,140-141$ & $"$ & - & - & - & 1.49 & 73.78 & 50.81 \\
\hline $15-6,63-73$ & $"$ & 1.520 & 2.306 & 2.11 & 1.44 & 73.08 & 52.04 \\
\hline $17-4,56-66$ & $"$ & 1.523 & 2.364 & 3.32 & 1.49 & 75.60 & 50.81 \\
\hline $18-2,74-88$ & $"$ & 1.546 & 2.250 & 4.60 & 1.52 & 69.91 & 47.03 \\
\hline $18-2,144-145$ & $"$ & - & - & - & 1.53 & 71.39 & 47.78 \\
\hline $18-3,70-73$ & $"$ & - & - & 1.33 & - & - & - \\
\hline $22-3,0-1$ & $"$ & - & - & - & 1.47 & 73.96 & 51.62 \\
\hline $23-2,60-70$ & clayey nannofossil qoze & 1.522 & 2.761 & 2.30 & 1.59 & 71.47 & 46.18 \\
\hline $23-3,60-63$ & $"$ & - & - & 2.30 & - & - & - \\
\hline $23-4,60-70$ & $"$ & 1.563 & 2.081 & 6.32 & 1.59 & 70.02 & 45.12 \\
\hline $23-5,11-14$ & $"$ & - & - & 6.89 & - & - & - \\
\hline $24-1,127-130$ & $"$ & - & - & 0.86 & - & - & - \\
\hline $24-3,127-130$ & $"$ & - & - & 0.96 & - & - & - \\
\hline $24-4,41-51$ & $"$ & 1.525 & 2.342 & 0.86 & 1.46 & 68.88 & 48.29 \\
\hline $24-5,79-82$ & $"$ & - & - & 2.30 & - & - & - \\
\hline $24-6,130-133$ & $"$ & - & - & 3.26 & - & - & - \\
\hline $25-2,60-71$ & $"$ & 1.512 & 1.414 & 4.02 & 1.51 & 72.93 & 49.55 \\
\hline $25-3,60-63$ & $"$ & - & - & 6.70 & - & - & - \\
\hline $26-1,105-108$ & $"$ & - & - & 3.26 & - & - & - \\
\hline $26-2,124-135$ & ", & 1.589 & 1.600 & 7.47 & 1.58 & 71.06 & 46.08 \\
\hline $27-1,35-38$ & $"$ & - & - & 0.86 & - & - & - \\
\hline $27-2,44-47$ & " & - & - & 6.13 & - & - & - \\
\hline $27-3,78-91$ & " & 1.520 & 2.514 & 2.49 & 1.45 & 67.16 & 47.46 \\
\hline $27-3,140-150$ & $"$ & - & - & - & 1.58 & 72.84 & 47.12 \\
\hline $28-2,42-52$ & $"$ & 1.551 & 2.250 & 3.64 & 1.57 & 70.98 & 46.36 \\
\hline $29-3,140-150$ & $"$ & - & - & - & 1.52 & 76.25 & 51.45 \\
\hline
\end{tabular}


TABLE 10 - Continued

\begin{tabular}{|c|c|c|c|c|c|c|c|}
\hline $\begin{array}{c}\text { Sample } \\
\text { (in terval in } \mathrm{cm} \text { ) }\end{array}$ & Lithology & $\begin{array}{c}\text { Sonic } \\
\text { Velocity } \\
(\mathrm{km} / \mathrm{s})\end{array}$ & $\begin{array}{c}\text { Thermal } \\
\text { Conductivity } \\
\text { (mcal } / \mathrm{cm}-\mathrm{s}^{\circ}{ }^{\circ} \mathrm{C} \text { ) }\end{array}$ & $\begin{array}{c}\text { Shear } \\
\text { Strength } \\
\left(\times 10^{-5} \text { dynes } / \mathrm{cm}^{2}\right)\end{array}$ & $\begin{array}{l}\text { Wet-Bulk } \\
\text { Density } \\
\left(\mathrm{g} / \mathrm{cm}^{3}\right)\end{array}$ & $\begin{array}{c}\text { Porosity } \\
(\%)\end{array}$ & $\begin{array}{l}\text { Water } \\
\text { Content } \\
(\%)\end{array}$ \\
\hline $443-29-5,38-53$ & clayey nannofossil ooze & 1.540 & 2.428 & 2.97 & 1.51 & 74.72 & 50.77 \\
\hline $30-2,109-123$ & mudstone & 1.565 & 2.378 & 6.03 & 1.53 & 68.65 & 46.00 \\
\hline $31-4,89-103$ & $"$ & 1.536 & 2.281 & 3.16 & 1.52 & 72.11 & 48.75 \\
\hline $32-1,138-148$ & $"$ & 1.544 & 2.114 & 2.68 & 1.45 & 71.45 & 50.51 \\
\hline $33-1,75-78$ & $"$ & - & - & 9.38 & - & - & - \\
\hline $443-33-2,76-86$ & " & 1.581 & 2.392 & - & 1.37 & 63.20 & 47.30 \\
\hline $33-3,19-22$ & $"$ & - & - & 3.45 & - & - & - \\
\hline $33-3,26-33$ & $"$ & - & - & 9.38 & 1.55 & 66.10 & 43.71 \\
\hline $34-4,74-77$ & $"$ & - & - & - & 1.54 & 74.38 & 49.44 \\
\hline $34-4,134-144$ & $"$ & 1.569 & 2.400 & - & 1.51 & 75.51 & 51.29 \\
\hline $35-2,64-74$ & $"$ & 1.585 & 2.267 & - & 1.46 & 74.53 & 50.93 \\
\hline $35-3,16-19$ & claystone & - & - & 2.87 & - & - & - \\
\hline $36-5,51-61$ & mudstone & 1.564 & 2.386 & - & 1.51 & 75.45 & 51.18 \\
\hline $39-1,90-100$ & claystone & 1.605 & 2.250 & 2.20 & 1.43 & 77.29 & 55.41 \\
\hline $40-1,140-150$ & " & - & - & - & 1.52 & 79.41 & 53.46 \\
\hline $40-2,100-113$ & $"$ & 1.642 & 2.281 & - & 1.48 & 74.02 & 51.16 \\
\hline $42-1,48-51$ & " & 1.623 & - & - & - & - & - \\
\hline $42-1,99-102$ & $"$ & - & - & 4.40 & - & - & - \\
\hline $42-1,100-101$ & $"$ & - & - & - & 1.43 & 75.51 & 53.93 \\
\hline $43-2,48-58$ & $"$ & 1.593 & 2.358 & - & 1.51 & 65.47 & 44.30 \\
\hline $45-1,140-150$ & $"$ & - & - & - & 1.56 & 78.91 & 50.50 \\
\hline $45-2,73-80$ & $"$ & 1.757 & - & - & 1.47 & 73.53 & 50.00 \\
\hline $46-2,38-51$ & $"$ & 1.667 & 2.494 & - & 1.46 & 73.40 & 50.44 \\
\hline $47-2,10-20$ & " & 1.599 & 2.233 & - & - & - & - \\
\hline $48-1,114-117$ & $"$ & 1.565 & - & - & - & - & - \\
\hline $49-2,68-69$ & $"$ & - & - & - & 1.75 & 65.19 & 37.17 \\
\hline $49-3,14-16$ & $"$ & - & - & - & 1.74 & 73.53 & 42.37 \\
\hline
\end{tabular}

\section{SUMMARY AND CONCLUSIONS}

\section{Summary}

The stratigraphic succession at Site 443 consists of 10 lithologic units, five of which are sedimentary and range in age from Miocene to Quaternary, and five of which are basalt.

The total penetration at Site 443 was 581.5 meters, and both a sedimentary section and the top of an igneous section were recovered. Depth of penetration into basalt was 124 meters.

An interpretation of the relative depth of deposition of the sedimentary units at Site 443 is shown in Figure 23. Calcareous organisms suggest that the depositional surface was above the $\mathrm{CCD}$, and probably below the lysocline.

The sediment accumulation rate fluctuated and was high during the early middle Miocene and during the Pleistocene. During the late middle Miocene, late Miocene, and Pliocene, sediment accumulation rates were intermediate. Deposition of sediment appears to have been continuous since the early middle Miocene. High sediment accumulation rates at Site $\mathbf{4 4 3}$ during the early middle Miocene owe their origin to resedimentation of ash and pelagic calcareous material by turbidity currents and to regional volcanism, whereas the high Pleistocene rates of accumulation owe their origin to increased regional volcanism and increased sediment erosion and supply during periods of lower sea level.

Most of the clays at this site are hemipelagic, authigenic components composing less than $5 \%$ of the total sediment.

Organic-carbon and nitrogen contents of the sediments show a steady decrease with depth. The $\mathrm{C} / \mathrm{N}$ ratio shows a similar trend, with slightly anomalous increases at depth of 200 to 250 meters and 300 to 400 meters.

The $p \mathrm{H}$ of the sediment averages 7.71 , alkalinity averages $4.70 \mathrm{meq} / \mathrm{kg}$, salinity averages 35.3 per mill and chlorinity averages 19.29 per mill.

Physical properties show a variety of major changes. The sonic velocity of the sediments averages $1.57 \mathrm{~km} / \mathrm{s}$, whereas for the basalts it averages $5.32 \mathrm{~km} / \mathrm{s}$. Average density for the sediments is $1.49 \mathrm{~g} / \mathrm{cm}^{3}$, and for the basalts, $2.81 \mathrm{~g} / \mathrm{cm}^{3}$. Porosity averages 70 per cent for the sediments (range $65-80 \%$ ), and for the basalts ranges from 0.7 to 27.0 per cent. The average shear strength of the sediments is 0.19 to $7.47 \times 10^{-5}$ dynes $/ \mathrm{cm}^{2}$. At Site 443 , a crude correlation of shear strength and depth can be extrapolated from 0 to 185 meters only; the data are too variable below that depth to define any meaningful trends.

The basalts are mostly olivine tholeiites analogous to oceanic basalts in composition, structure, and vesicularity. Hydrothermal alteration of basalt appears to in- 
TABLE 11

Summary of Physical Properties of Igneous Rocks, Hole 443

\begin{tabular}{|c|c|c|c|c|c|c|}
\hline $\begin{array}{c}\text { Sample } \\
\text { (interval in } \mathrm{cm} \text { ) }\end{array}$ & $\begin{array}{l}\text { Piece } \\
\text { No. }\end{array}$ & $\begin{array}{c}\text { Sonic } \\
\text { Velocity } \\
(\mathrm{km} / \mathrm{s})\end{array}$ & $\begin{array}{c}\text { Thermal } \\
\text { Conductivity } \\
\text { (mcal/cm-s- }{ }^{\circ} \mathrm{C} \text { ) }\end{array}$ & $\begin{array}{l}\text { Wet-Bulk } \\
\text { Density } \\
\left(\mathrm{g} / \mathrm{cm}^{3}\right)\end{array}$ & $\begin{array}{l}\text { Grain } \\
\text { Density } \\
\left(\mathrm{g} / \mathrm{cm}^{3}\right)\end{array}$ & $\begin{array}{l}\text { Porosity } \\
\text { (\%) }\end{array}$ \\
\hline $443-49-3,121-131$ & $8 a$ & - & 4.175 & - & - & - \\
\hline $49-3,137-143$ & $8 \mathrm{~b}$ & 5.800 & - & 3.10 & 3.11 & 0.31 \\
\hline $49-4,79-89$ & 7 & - & 4.458 & - & - & - \\
\hline $50-1,117-122$ & $11 \mathbf{a}$ & 5.906 & - & 2.95 & 2.97 & 0.74 \\
\hline $50-2,0-10$ & la & - & 4.350 & - & - & - \\
\hline $50-4,127-137$ & 6 & - & 4.353 & - & - & - \\
\hline $52-1,66-76$ & 5 & - & 4.417 & - & - & - \\
\hline $52-1,85-87$ & $6 f$ & 5.065 & - & 2.95 & 3.02 & 3.72 \\
\hline $52-2,119-129$ & $4 \mathrm{~h}$ & - & 4.419 & - & - & - \\
\hline $52-3,85-87$ & $6 a$ & - & - & 2.84 & 2.96 & 5.81 \\
\hline $52-3,107-110$ & $6 \mathrm{~b}$ & 5.364 & - & - & - & - \\
\hline $53-1,115-125$ & $9 \mathrm{~b}$ & 5.300 & 4.100 & 2.95 & 3.01 & 3.07 \\
\hline $53-2,48-58$ & Id & - & 4.164 & - & - & - \\
\hline $53-3,83-93$ & $5 c$ & - & 4.100 & - & - & - \\
\hline $54-1,90-92$ & $6 a$ & 5.868 & - & 2.88 & 3.00 & 6.05 \\
\hline $54-1,120-130$ & 7 & - & 4.139 & - & - & - \\
\hline $54-2,132-142$ & $1 \mathrm{~g}$ & - & 4.522 & - & - & - \\
\hline $54-3,0-13$ & la & 5.826 & 4.272 & 2.93 & 3.05 & 5.72 \\
\hline $54-3,124-134$ & $\mathrm{lg}$ & - & 4.192 & - & - & - \\
\hline $54-4,15-25$ & la & - & 4.175 & - & - & - \\
\hline $54-4,70-80$ & $1 d$ & - & 3.556 & - & - & - \\
\hline $54-4,140-150$ & $1 \mathrm{~g}$ & - & 4.556 & - & - & - \\
\hline $54-5,2-12$ & la & - & 4.611 & - & - & - \\
\hline $54-5,45-55$ & 1e & - & 4.547 & - & - & - \\
\hline $54-5,145-155$ & 10 & - & 4.092 & - & - & - \\
\hline $54-6,28-38$ & Ib & - & 4.139 & - & - & - \\
\hline $54-7,60-70$ & Id & 5.913 & 4.533 & 2.97 & 3.14 & 7.98 \\
\hline $54-7,67-69$ & id & - & - & 2.93 & 3.00 & 3.53 \\
\hline $55-1,77-80$ & $9 c$ & 4.002 & - & 2.51 & 2.95 & 22.63 \\
\hline $56-1,61-71$ & $8 \mathrm{a}$ & - & 3.256 & - & - & - \\
\hline $56-1,105-115$ & $8 f$ & - & 3.333 & - & - & - \\
\hline $56-2,49-59$ & $5 \mathrm{a}$ & 3.941 & 3.347 & 2.46 & 3.00 & 27.07 \\
\hline $56-2,94-104$ & 8 & - & 3.269 & - & - & - \\
\hline $56-3,97-107$ & $11 \mathrm{~b}$ & - & 3.514 & - & - & - \\
\hline $56-3,115-125$ & $12 \mathrm{~b}$ & - & 3.644 & - & - & - \\
\hline $56-4,0-10$ & 1 & - & 3.484 & - & - & - \\
\hline $57-1,0-10$ & la & - & 3.628 & - & - & - \\
\hline $57-1,70-72$ & 5 & 4.450 & - & 2.59 & 3.01 & 20.61 \\
\hline $57-1,125-135$ & 9d & - & 3.583 & - & - & - \\
\hline $58-1,82-92$ & $7 e$ & - & 3.573 & - & - & - \\
\hline $58-3,120-130$ & $4 a$ & - & 3.625 & - & - & - \\
\hline $58-3,137-143$ & $4 \mathrm{~b}$ & 3.816 & - & 2.60 & 2.99 & 19.59 \\
\hline $58-3,114-124$ & $4 c$ & - & 3.772 & - & - & - \\
\hline $59 \cdot 2,14-24$ & lb & - & 4.303 & - & - & - \\
\hline $59-3,98-100$ & $8 a$ & 5.222 & - & 2.84 & 3.00 & 8.24 \\
\hline $59-3,136-146$ & $8 c$ & - & 4.078 & - & - & - \\
\hline $59 \cdot 4,138-148$ & $6 \mathrm{~b}$ & - & 4.130 & - & - & - \\
\hline $60-1,0-10$ & $1 \mathrm{a}$ & - & 4.458 & - & - & - \\
\hline $60-2,8-18$ & $1 \mathrm{a}$ & 4.823 & 4.372 & 2.75 & 2.98 & 11.22 \\
\hline $60-2,134-144$ & $1 \mathrm{j}$ & - & 4.267 & - & - & - \\
\hline $60-3,99-109$ & $1 \mathrm{~d}$ & - & 4.386 & - & - & - \\
\hline $60-5,113-118$ & $1 \mathrm{~g}$ & 5.636 & - & 2.89 & 2.94 & 2.37 \\
\hline $61-2,0-10$ & $1 \mathrm{a}$ & - & 4.342 & - & - & - \\
\hline $61-4,77-81$ & $1 d$ & 5.749 & - & 2.90 & 2.97 & 3.78 \\
\hline $62-1,15-25$ & $1 \mathrm{~b}$ & - & 3.792 & - & - & - \\
\hline $62-2,43-49$ & $2 a$ & 4.872 & - & 2.69 & 2.95 & 13.19 \\
\hline $63-3,103-105$ & $5 \mathrm{a}$ & 5.029 & - & - & - & - \\
\hline $63-3,105-115$ & $5 b$ & - & 3.964 & 2.75 & 2.85 & 5.41 \\
\hline $64-1,24-29$ & $2 \mathrm{~b}$ & 5.185 & - & 2.83 & 3.03 & 9.82 \\
\hline $64-2,130-140$ & $3 \mathrm{~b}$ & - & 4.078 & - & - & - \\
\hline
\end{tabular}

crease with depth, and the association of zeolites, smectite, calcite, chlorite, pyrite, and native copper indicates an alteration temperature of $200^{\circ} \mathrm{C}$ or less. The pillow basalts show a high degree of oxidation. Alteration of the Site 443 basalts is greater than that at Site 442 . Chemical composition of glasses in these basalts is nearly identical to that of glass from mid-ocean ridges (Dick et al., this volume).

Paleomagnetism measurements show that Site 443 has been approximately at or slightly south of the present latitude since the early Miocene. The average intensity of natural remanent magnetization for the basalts is 2 to $10 \times 10^{-3}$ gauss $/ \mathrm{cm}^{3}$. The basal sediment and top of the basalt represent the same period of magneticpolarity reversal and are therefore of very similar age.
TABLE 12

Wet-Bulk Density and Porosity from 2-Minute GRAPE Counts for Igneous Rocks, Hole 443

\begin{tabular}{|c|c|c|c|}
\hline $\begin{array}{c}\text { Sample } \\
\text { (interval in } \mathrm{cm} \text { ) }\end{array}$ & $\begin{array}{l}\text { Piece } \\
\text { No. }\end{array}$ & $\begin{array}{l}\text { Wet-Bulk } \\
\text { Density } \\
\left(\mathrm{g} / \mathrm{cm}^{3}\right)\end{array}$ & $\begin{array}{c}\text { Porosity } \\
(\%)\end{array}$ \\
\hline $443-49-3,101-103^{a}$ & $4 \mathrm{c}$ & 2.82 & 10.58 \\
\hline $49-3,134-136$ & $8 \mathrm{~b}$ & 2.82 & 10.72 \\
\hline $49-3,145-147$ & 9 & 2.79 & 12.05 \\
\hline $49-4,40-42^{\mathrm{a}}$ & $5 \mathrm{a}$ & 2.91 & 6.02 \\
\hline $49-4,74-76$ & 6 & 2.81 & 11.29 \\
\hline $49-4,102-104^{a}$ & 8 & 2.84 & 9.69 \\
\hline $50-1,85-87^{a}$ & 9 & 2.86 & 8.53 \\
\hline $50-1,118-120$ & $11 \mathrm{a}$ & 2.80 & 11.32 \\
\hline $50-2,30-32^{a}$ & $1 \mathrm{~b}$ & 2.88 & 7.65 \\
\hline $50-2,127-129$ & 6 & 2.82 & 10.66 \\
\hline $50-4,2-4^{a}$ & $1 \mathrm{a}$ & 2.89 & 6.91 \\
\hline $50-4,66-68$ & 5 & 2.82 & 10.77 \\
\hline $51-1,9-11^{\mathrm{a}}$ & 2 & 2.87 & 8.27 \\
\hline $52-1,33-35 a$ & $5 b$ & 2.82 & 10.44 \\
\hline $52-1,125-127$ & 61 & 2.71 & 16.06 \\
\hline $52-2,119-121$ & $4 \mathrm{~h}$ & 2.76 & 13.36 \\
\hline $52-2,120-122^{a}$ & $4 \mathrm{~h}$ & 2.89 & 6.91 \\
\hline $52-4,21-23^{a}$ & 1 & 2.87 & 7.85 \\
\hline $53-1,7-9 a$ & 1 & 2.91 & 6.02 \\
\hline $53-1,115-117$ & $9 b$ & 2.74 & 14.76 \\
\hline $53-2,12-14^{a}$ & $1 \mathrm{~b}$ & 2.87 & 8.25 \\
\hline $53-2,48-50$ & $1 \mathrm{~d}$ & 2.81 & 10.88 \\
\hline $53-3,83-85$ & $5 \mathrm{c}$ & 2.81 & 10.94 \\
\hline $54-1,54-56^{a}$ & $4 b$ & 2.95 & 2.05 \\
\hline $54-1,119-121$ & 7 & 2.82 & 10.39 \\
\hline $54-2,54-56^{a}$ & $1 b$ & 2.91 & 6.02 \\
\hline $54-2,132-134$ & $1 \mathrm{~g}$ & 2.84 & 9.55 \\
\hline $54-2,138-140^{a}$ & $1 \mathrm{~g}$ & 2.91 & 6.41 \\
\hline $54-3,0-2$ & 1a & 2.90 & 6.59 \\
\hline $54-3,124-126$ & $1 \mathrm{~g}$ & 2.80 & 11.56 \\
\hline $54-3,125-127 a$ & $1 \mathrm{~g}$ & 2.93 & 4.84 \\
\hline $54-4,15-17$ & $1 \mathrm{~g}$ & 2.81 & 10.86 \\
\hline $54-4,70-72$ & $1 \mathrm{~d}$ & 2.83 & 9.96 \\
\hline $54-4,140-142$ & $1 \mathrm{~g}$ & 2.92 & 5.54 \\
\hline $54-4,146-148^{a}$ & $1 \mathrm{~g}$ & 2.87 & 7.89 \\
\hline $54-5,8-10$ & $1 \mathrm{a}$ & 2.86 & 8.63 \\
\hline $54-5,45-47$ & $1 \mathrm{c}$ & 2.80 & 11.11 \\
\hline $54-5,145-147$ & 10 & 2.77 & 13.41 \\
\hline $54-5,146-148^{a}$ & 10 & 2.81 & 11.21 \\
\hline $54-6,14-16^{a}$ & $1 \mathrm{a}$ & 2.87 & 8.14 \\
\hline $54-6,28-30$ & $1 \mathrm{~b}$ & 2.86 & 8.31 \\
\hline $54-7,19-21$ & 1a & 2.83 & 10.09 \\
\hline $54-7,60-62$ & $1 \mathrm{~d}$ & 2.87 & 7.94 \\
\hline $54-7,76-78^{a}$ & $1 \mathrm{e}$ & 2.94 & 4.53 \\
\hline $54-7,137-139$ & 6 & 2.47 & 27.77 \\
\hline $54-7,138-140^{a}$ & 6 & 2.41 & 31.11 \\
\hline $55-1,78-80$ & $9 \mathrm{c}$ & 2.45 & 27.54 \\
\hline $55-1,99-101^{a}$ & $10 \mathrm{a}$ & 2.59 & 20.27 \\
\hline $55-1,145-147$ & 14 & 2.48 & 26.09 \\
\hline $55-2,60-62^{a}$ & 5 & 2.61 & 19.10 \\
\hline $56-1,71-73$ & $7 \mathrm{~b}$ & 2.47 & 26.09 \\
\hline $56-1,71-73$ & 8 & 2.48 & 25.95 \\
\hline $56-1,117-119 a$ & 8 & 2.53 & 23.58 \\
\hline $56-2,49-51$ & $5 \mathrm{a}$ & 2.43 & 28.56 \\
\hline $56-2,94-96$ & 8 & 2.47 & 26.45 \\
\hline $56-2,100-102^{a}$ & 8 & 2.32 & 34.19 \\
\hline $56-3,97-99$ & $11 \mathrm{~b}$ & 2.48 & 25.81 \\
\hline $56-3,115-117$ & $12 \mathrm{~b}$ & 2.51 & 24.41 \\
\hline $56-3,120-122^{a}$ & $12 \mathrm{~b}$ & 2.58 & 21.04 \\
\hline $56-4,0-2$ & 1 & 2.54 & 23.00 \\
\hline $56-4,17-19$ & 2 & 2.44 & 27.83 \\
\hline $57-1,134-136$ & $9 \mathrm{~d}$ & 2.61 & 19.13 \\
\hline
\end{tabular}


TABLE 12 - Continued

\begin{tabular}{|c|c|c|c|}
\hline $\begin{array}{c}\text { Sample } \\
\text { (interval in } \mathrm{cm} \text { ) }\end{array}$ & $\begin{array}{l}\text { Piece } \\
\text { No. }\end{array}$ & $\begin{array}{l}\text { Wet-Bulk } \\
\text { Density } \\
\left(\mathrm{g} / \mathrm{cm}^{3}\right)\end{array}$ & $\begin{array}{c}\text { Porosity } \\
(\%)\end{array}$ \\
\hline $\begin{array}{c}443-57-2,125-127 \\
58-1,61-63^{a} \\
58-1,82-84\end{array}$ & $\begin{array}{c}14 \\
7 \mathrm{c} \\
7 \mathrm{e}\end{array}$ & $\begin{array}{l}2.59 \\
2.55 \\
2.51\end{array}$ & $\begin{array}{l}20.13 \\
22.52 \\
24.58\end{array}$ \\
\hline $\begin{array}{l}58-2,67-69^{a} \\
58-3,120-122 \\
58-3,121-123^{a} \\
58-4,69-71^{a} \\
58-4,114-116\end{array}$ & $\begin{array}{l}6 \\
4 a \\
4 a \\
6 \\
4 c\end{array}$ & $\begin{array}{l}2.46 \\
2.47 \\
2.57 \\
2.89 \\
2.55\end{array}$ & $\begin{array}{r}26.88 \\
26.34 \\
21.25 \\
5.27 \\
22.37\end{array}$ \\
\hline $\begin{array}{l}59-1,12-14^{\mathrm{a}} \\
59-1,71-73 \\
59-2,14-16 \\
59-2,106-108^{\mathrm{a}} \\
59-2,116-118\end{array}$ & $\begin{array}{c}2 \\
11 \mathrm{c} \\
1 \mathrm{a} \\
8 \mathrm{~g} \\
9\end{array}$ & $\begin{array}{l}2.79 \\
2.76 \\
2.78 \\
2.89 \\
2.78\end{array}$ & $\begin{array}{r}8.26 \\
10.27 \\
9.29 \\
3.80 \\
9.55\end{array}$ \\
\hline $\begin{array}{l}59-3,12-14 \\
59-3,136-138 \\
59-4,5-7 \\
59-4,138-140 \\
59-4,142-144 a\end{array}$ & $\begin{array}{l}1 \mathrm{~b} \\
8 \mathrm{c} \\
1 \mathrm{a} \\
6 \mathrm{~b} \\
6 \mathrm{~b}\end{array}$ & $\begin{array}{l}2.82 \\
2.66 \\
2.58 \\
2.57 \\
2.67\end{array}$ & $\begin{array}{r}7.43 \\
15.55 \\
19.43 \\
20.01 \\
15.08\end{array}$ \\
\hline $\begin{array}{l}60-1,16-18^{a} \\
60-1,111-113^{a} \\
60-1,111-113 \\
60-2,8-10 \\
60-2,110-112^{a}\end{array}$ & $\begin{array}{l}1 \mathrm{a} \\
4 \mathrm{e} \\
4 \mathrm{e} \\
1 \mathrm{a} \\
1 \mathrm{j}\end{array}$ & $\begin{array}{l}2.59 \\
2.79 \\
2.66 \\
2.59 \\
2.86\end{array}$ & $\begin{array}{r}19.18 \\
9.07 \\
15.56 \\
19.35 \\
5.22\end{array}$ \\
\hline $\begin{array}{l}60-2,134-136 \\
60-3,74-76 \\
60-3,99-101 \\
60-4,125-127^{a} \\
60-4,125-127\end{array}$ & $\begin{array}{l}1 \mathrm{j} \\
1 \mathrm{c} \\
1 \mathrm{~d} \\
3 \mathrm{~h} \\
3 \mathrm{~h}\end{array}$ & $\begin{array}{l}2.60 \\
2.87 \\
2.65 \\
2.86 \\
2.71\end{array}$ & $\begin{array}{r}18.54 \\
4.50 \\
15.89 \\
5.04 \\
13.14\end{array}$ \\
\hline $\begin{array}{l}61-1,89-91^{\mathrm{a}} \\
61-1,103-105^{\mathrm{a}} \\
61-4,106-108^{\mathrm{a}} \\
62-1,90-92^{\mathrm{a}} \\
62-2,29-31^{\mathrm{a}} \\
62-4,62-64^{\mathrm{a}}\end{array}$ & $\begin{array}{l}1 \mathrm{~b} \\
2 \mathrm{~b} \\
1 \mathrm{~d} \\
3 \mathrm{c} \\
1 \mathrm{~b} \\
3 \mathrm{c}\end{array}$ & $\begin{array}{l}2.86 \\
2.87 \\
2.79 \\
2.74 \\
2.80 \\
2.77\end{array}$ & $\begin{array}{r}5.07 \\
4.73 \\
8.56 \\
11.33 \\
8.50 \\
9.65\end{array}$ \\
\hline
\end{tabular}

a counts through basalt minicores

Two normal- and two reversed-polarity zones were identified in the basalt succession.

\section{Conclusions} sions:

Our data from Site 443 permit the following conclu-

1. The age of the sediment immediately above the basalt basement, dated from fossils in the sediment recovered from Sample 443-49-3, $55 \mathrm{~cm}$, is early middle Miocene (14-15 m.y.; Sphenolithus heteromorphus Zone of nannofossils). However, a water sample recovered during retrieval of basalt in Core 50 contained sediment and some nannofossils older than 15 m.y. This implies that the oldest sediment at the sediment/basalt contact was not recovered. The $15-\mathrm{m} . \mathrm{y}$. biostratigraphic age is at variance with the age of magnetic anomaly $6 \mathrm{~A}$ (23 m.y.) postulated by Kobayashi and Nakata (1977). A K-Ar age determination on the youngest pillow basalt gives an age of $17.2 \pm 3.1$ m.y. (E.H. McKee, pers. comm.; see Klein and Kobayashi, this volume).

2. The depositional surface at Site 443 was always slightly above or well above the CCD, but below the ly-

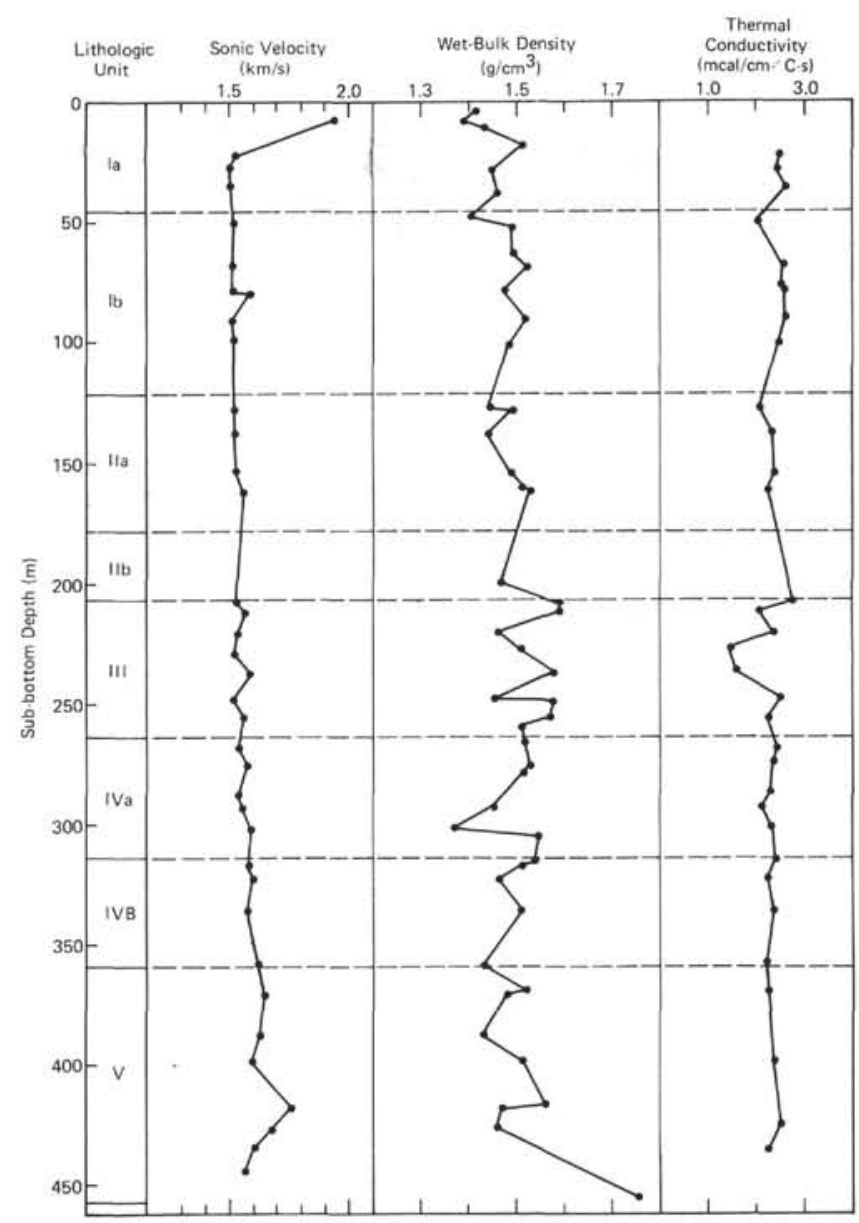

Figure 14. Sonic velocity, wet-bulk density, and thermal conductivity versus depth for Site 443 sediments.

socline. Poor preservation of foraminifers throughout the column indicates deposition below the lysocline, although beds of nannofossil ooze and chalk suggest deposition well above the CCD. The exact depth of deposition cannot be determined exactly, because no data are availale concerning present or past elevations of the CCD and lysocline in the Shikoku Basin. However, assuming the general Pacific Ocean CCD curve of Van Andel et al. (1975) the depositional surface at Site 443 was no less than 3800 meters (Figure 23).

3. All the interbedded ash and carbonate beds of unit $\mathrm{V}$ were deposited by resedimentation by turbidity currents. Evidence of resedimentation includes graded beds and mixing and reworking of the nannofossil and foraminifer faunas. Also, hemipelagic clays are interbedded with pelagic chalk in this interval. The reworked sediments were derived from a local source such as the slopes of a seamount. The remaining clays are hemipelagic and were deposited in a distal or basinal facies; in this way they are analogous to those at Site 442. The Site 443 hemipelagic clays were deposited on the western edge of an eastward-thickening clastic wedge recognized from seismic surveys by Marauchi and Asanuma $(1974,1977)$ and by preliminary contouring of sediment thicknesses from seismic records by Karig (1975, p. 962, Fig. 3). This clastic wedge thickens 


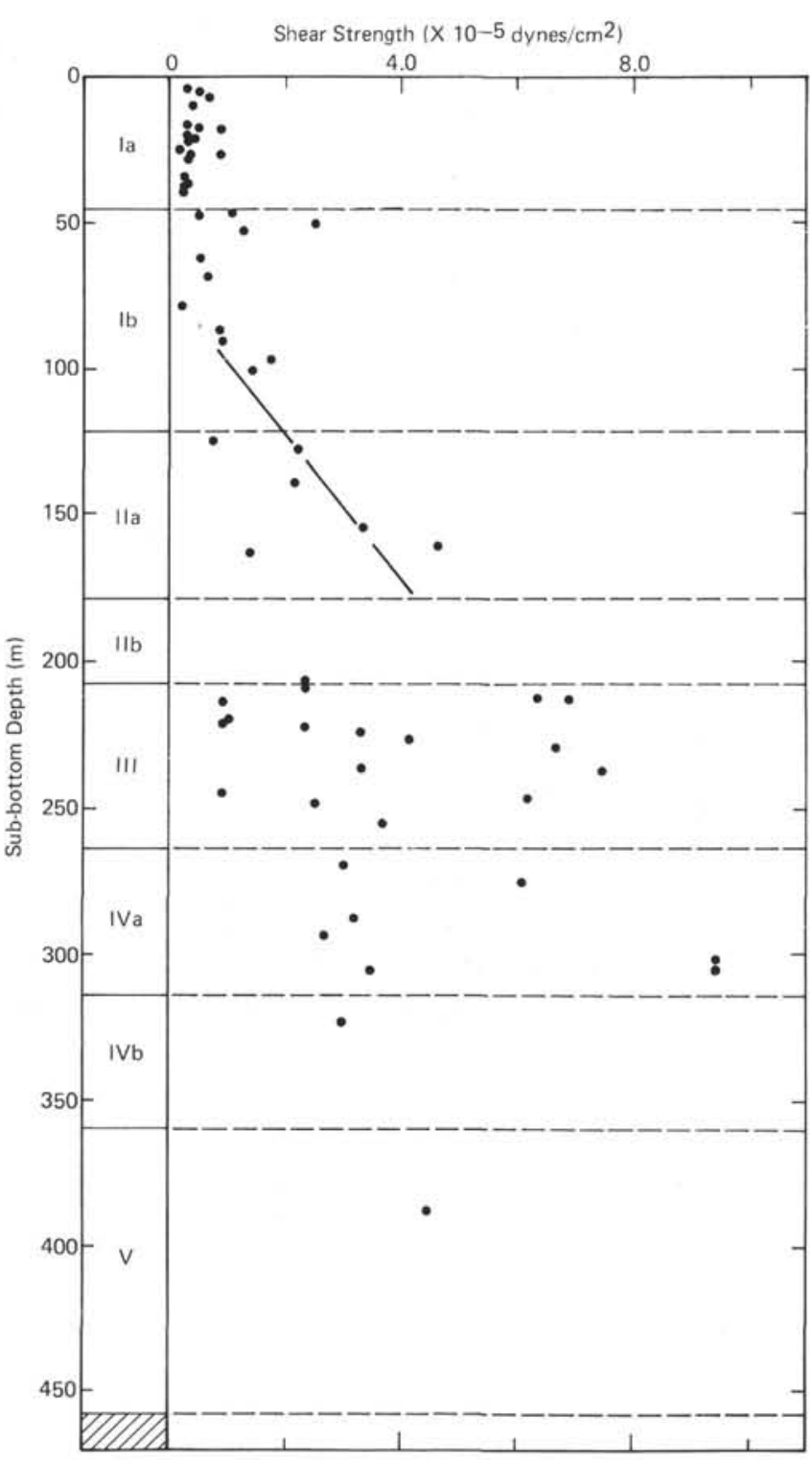

Figure 15. Shear strength versus depth for Site 443 sediments.

toward the Iwo Jima Ridge. We assume that the Iwo Jima Ridge is the most likely source for these sediments.

4. The olivine basalts at Site 443 are characterized by two types of alteration: hydrothermal and oxidative. Hydrothermal alteration is associated with calcite veins, and the alteration zones are enriched in calcite, smectite, and zeolites. These hydrothermal veins contain native copper and owe their origin to low-temperature processes at $200^{\circ} \mathrm{C}$ or less. Zones of higher-temperature alteration were observed in the upper basalt units, where chlorite, serpentine, and talc occur in veins and as replacements of olivine. Vesicles filled with calcite and pyrite also indicate a higher temperature of alteration.

All the basalts show evidence of oxidation at the top and base of each flow unit and along calcite veins. The Site 443 basalts are more oxidized than those at Site 442 .

Paleomagnetic-reversal data indicate that the upper 125 meters of basalt at Site 443 most probably were ex-

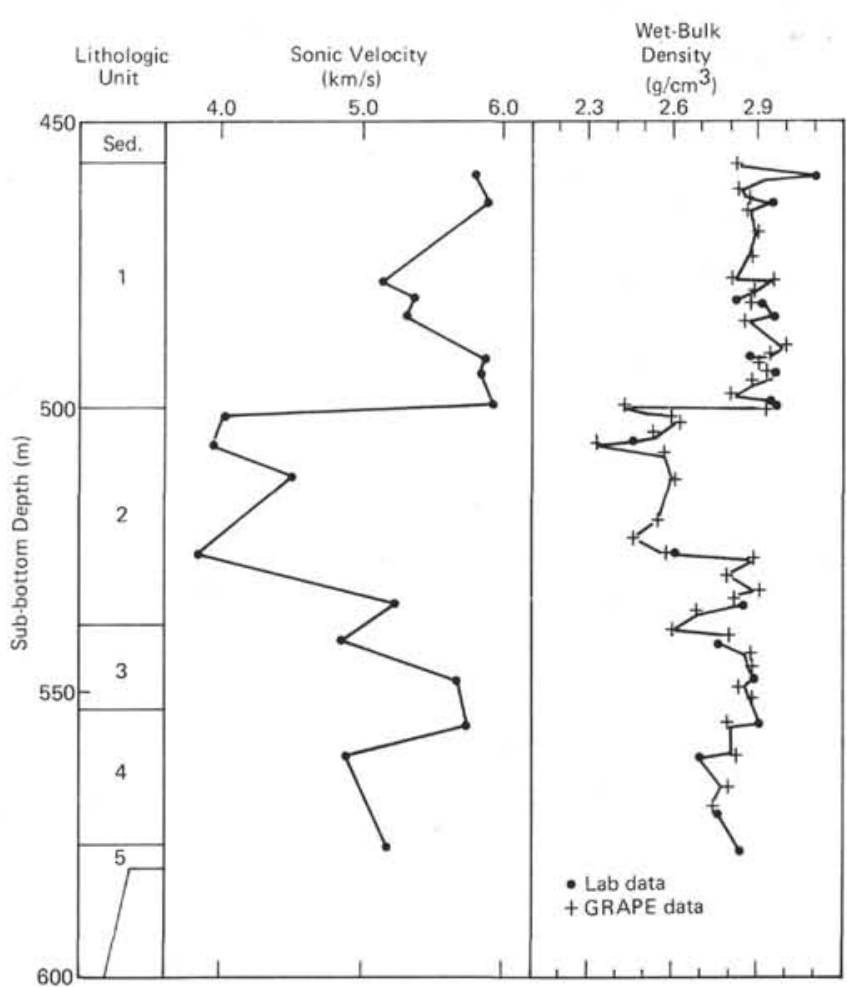

Figure 16. Sonic velocity and wet-bulk density versus depth for Site 443 basalts. Crosses on wet-bulk density graph correspond to values determined from 2-minute GRAPE counts; dots correspond to values determined through laboratory measurements.

truded over a period of at least 200,000 years, whereas the basalts at Site 442 appear to have been extruded over a much shorter time. This duration of extrusion suggests that at Site 443 volcanism was more episodic, thus permitting the weathering of basalt.

\section{REFERENCES}

Andrews, J. E., Packham, G. H., et al., 1975. Init. Repts. $D S D P$, 30: Washington (U. S. Govt. Printing Office).

Berggren, W. A., 1972. A Cenozoic time-scale-some implications for regional geology and paleogeography. Lethaia, 5, 195-215.

Berggren, W. A., and Van Couvering, J. A., 1974. The late Neogene biostratigraphy, geochronology and paleoclimatology of the last 15 million years in marine and continental sequences. Palaeogeography Palaeoclimatology Palaeoecology, 16, 1-216.

Bukry, D., 1975. Coccolith and silicoflagellate stratigraphy, northwestern Pacific Ocean, Deep Sea Drilling Project Leg 32. In Larson, R. A., Moberly, R. M., Jr., et al., Init. Repts. DSDP, 32: Washington (U. S. Govt. Printing Office), pp. 677-718.

Donnelly, T. W., 1975. Neogene explosive volcanic activity of the western Pacific: Sites 292 and 296. In Karig, D. E., Ingle, J. C., Jr., et al., Init. Repts. DSDP, 31: Washington (U. S. Govt. Printing Office), pp. 577-597.

Fischer, A. G., Heezen, B. C., et al., 1971. Init. Repts. DSDP, 6: Washington (U. S. Govt. Printing Office).

IPOD-Japan, 1977. Multi-channel seismic reflection data across the Shikoku Basin and the Daito Ridges, 1976. IPOD-Japan Basic Data Ser. No. 1. 


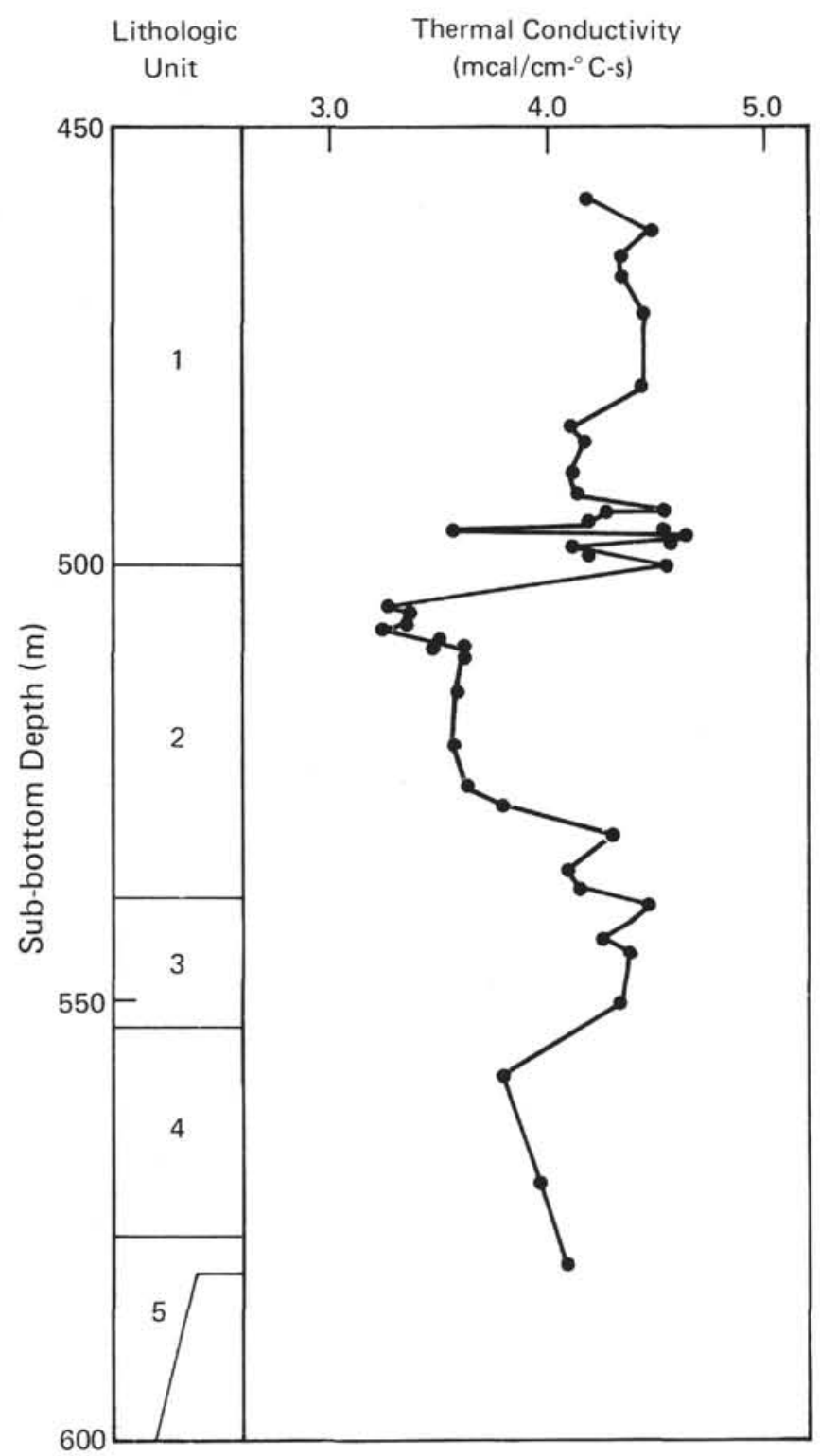

Figure 17. Thermal conductivity versus depth for Site 443 basalts. Data correspond to laboratorydetermined values.

TABLE 13

Averages of Physical Properties of Site 443 Basalts Within Various Depth Intervals

Sub-Bottom Depth

(m)

\begin{tabular}{lccc}
\multicolumn{1}{c}{ Physical Property } & $457.00-501.78$ & $501.78-525.00$ & $>525$ \\
\hline $\begin{array}{l}\text { Wet-Bulk Density } \\
\left(\mathrm{g} / \mathrm{cm}^{3} \text { ) }\right.\end{array}$ & 2.95 & 2.54 & 2.81 \\
$\begin{array}{l}\text { Sonic Velocity } \\
(\mathrm{km} / \mathrm{s})\end{array}$ & 5.60 & 4.05 & 5.22 \\
$\begin{array}{l}\text { Grain Density } \\
\left(\mathrm{g} / \mathrm{cm}^{3} \text { ) }\right.\end{array}$ & 3.031 & 2.988 & 2.960 \\
$\begin{array}{l}\text { Thermal Conductivity } \\
\left(\mathrm{mcal} / \mathrm{cm}^{\circ}{ }^{\circ} \mathrm{C}-\mathrm{s}\right)\end{array}$ & 4.28 & 3.47 & 4.16 \\
\begin{tabular}{l} 
Porosity $(\%)$ \\
\hline
\end{tabular} & 4.18 & 22.48 & 7.72 \\
\hline
\end{tabular}

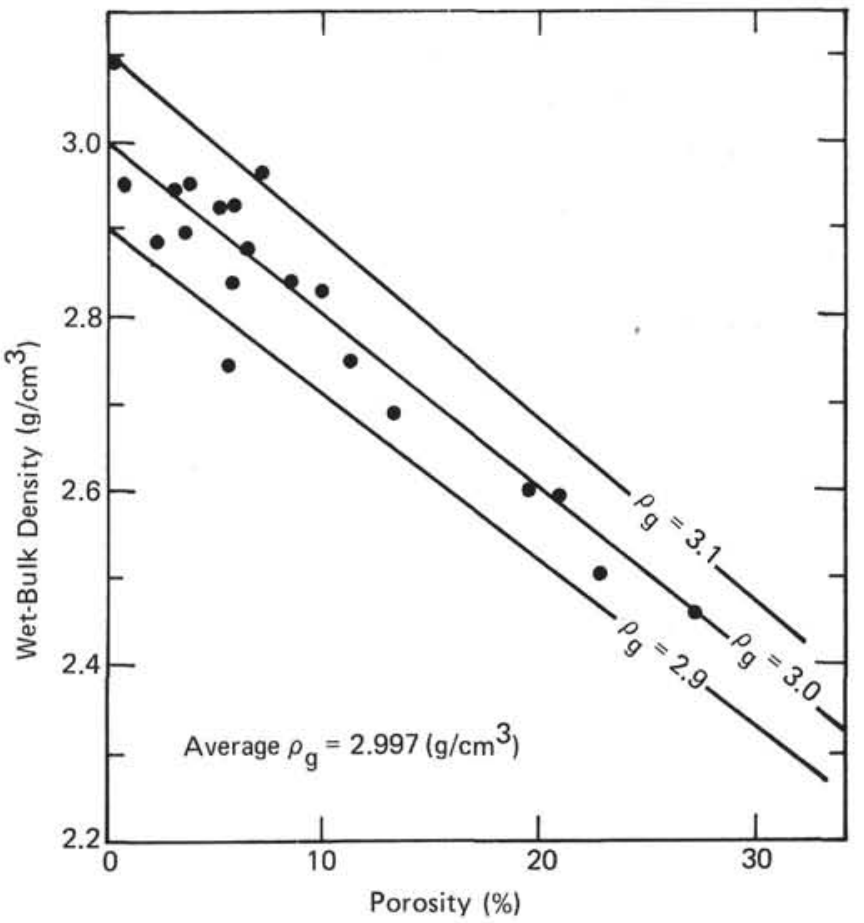

Figure 18. Wet-bulk density plotted as a function of porosity. Lines correspond to predicted wet-bulk density for basalts of varying porosity with given grain densities $\left(\varrho_{g}\right)$.

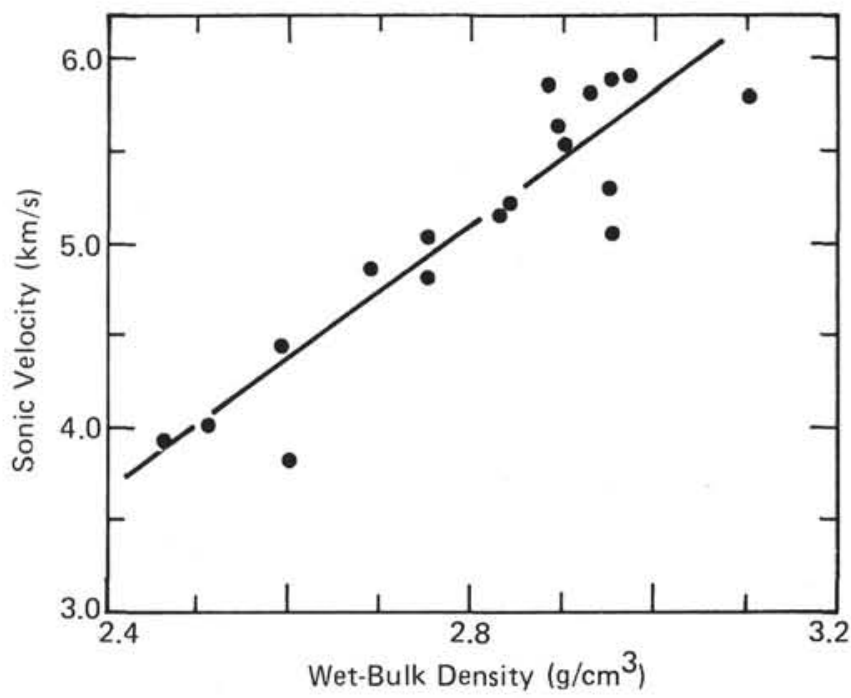

Figure 19. Sonic velocity plotted as a function of wetbulk density for Site 443 basalts.

Karig, D. E., 1975. Basin genesis in the Philippine Sea. In Karig, D. E., Ingle, J. C., Jr., et al., Init. Repts. DSDP, 31: Washington (U. S. Govt. Printing Office), pp. 857-880.

Karig, D. E., Ingle, J. C., Jr., et al., 1975. Init. Repts. DSDP, 31: Washington (U. S. Govt. Printing Office).

Kennett, J. P., McBirney, A. R., and Thunnell, R. C., 1977. Episodes of Cenozoic volcanism in the Circum-Pacific Region. J. Volcanol. and Geochem. Res., 2, 145-163.

Kobayashi, K., and Isezaki, N., 1976. Magnetic anomalies in the Sea of Japan and the Shikoku Basin: possible tectonic 


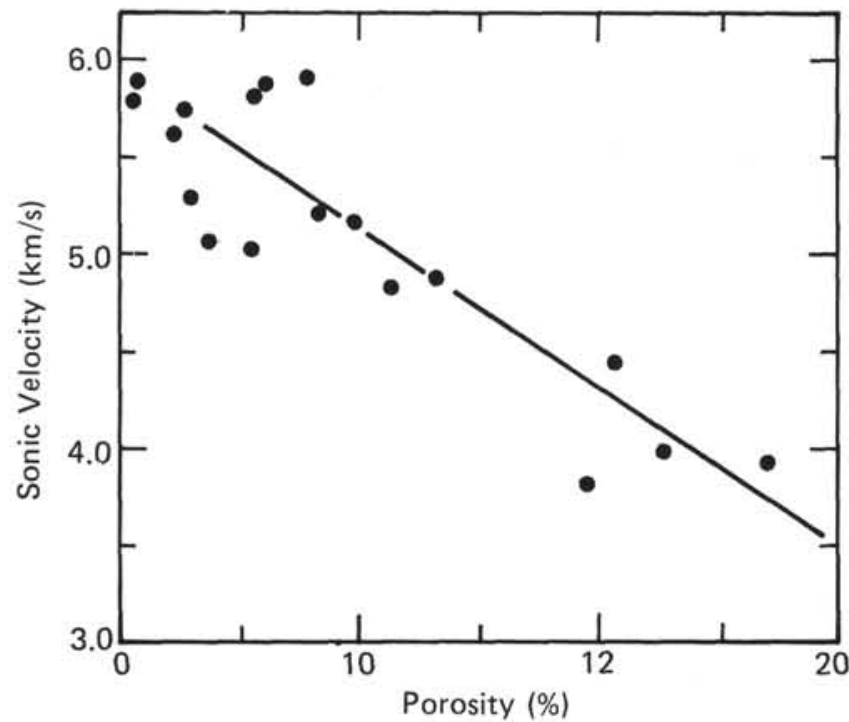

Figure 20. Sonic velocity plotted as a function of porosity for Site 443 basalts.

implications. In The Geophysics of the Pacific Ocean Basin and its Margin: Am. Geophys. Union Monogr. 19, 235-251.

Kobayashi, K., and Nakata, M., 1977. Local magnetic anomaly profiles, Shikoku Basin, northwestern Pacific Ocean (Map): Contrib. Geodynamics Project Japan, 77-2.

Ling, Hsin Yi, 1975. Radiolaria: Leg 31 of the Deep Sea Drilling Project. In Karig, D. E., Ingle, J. C., et al., Init. Repts. $D S D P, 31$ : Washington (U. S. Govt. Printing Office), pp. 703-762.

Luyendyk, B., Cann, J., et al., 1979. Init. Repts. DSDP, 49: Washington (U. S. Govt. Printing Office).

Murauchi, S., and Asanuma, T., 1974. Seismic reflection profiles and sonobuoy refraction measurements during GDP-6 to -8 voyages. Mar. Sci., 6, 23-27. [in Japanese with English abstract]

1977. Seismic Reflection Profiles in the Western

Pacific, 1965-1974: Tokyo (University of Tokyo Press).

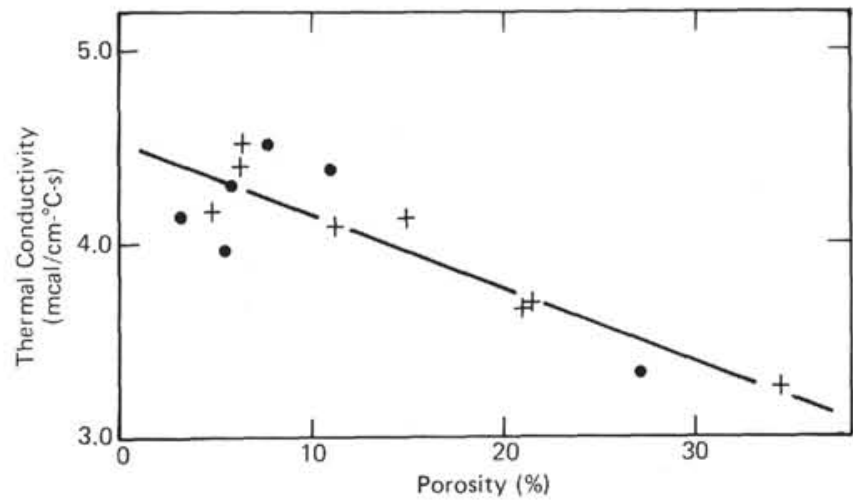

Figure 21. Thermal conductivity plotted as a function of porosity for Site 443 basalts. Dots correspond to values of porosity determined in the laboratory; crosses correspond to porosity values calculated from 2-minute GRAPE counts.

Ridley, W. I., Rhodes, J. M., Reid, A. M., Jakes, P., Shih, C., and Bass, M. N., 1974. Basalts from Leg 6 of the DeepSea Drilling Project. J. Petrol., 15, 140-159.

Saito, T., 1977. Late Cenozoic planktonic foraminifera datum levels: the present state of knowledge towards accomplishing Pan-Pacific stratigraphic correlation. Proc. First Internat. Cong. Pacific Neogene Stratigraphy, 61-80.

Tomoda, Y., Kobayashi, K., Segawa, J., Nomora, M., Kimura, K., and Saki, T., 1975. Linear magnetic anomalies in the Shikoku Basin, northeastern Philippine Sea. J. Geomagnet. and Geoelec., 28, 47-56.

van Andel, Tj. H., and Heath, G. R., and Moore, T. C., Jr., 1975. Cenozoic history and paleoceanography of the Central Equatorial Pacific Ocean. Geol. Soc. Mem., 143.

Watts, A. N., and Weissel, J. K., 1975. Tectonic history of the Shikoku marginal basin. Earth Planet. Sci. Lett., 25, $239-250$ 


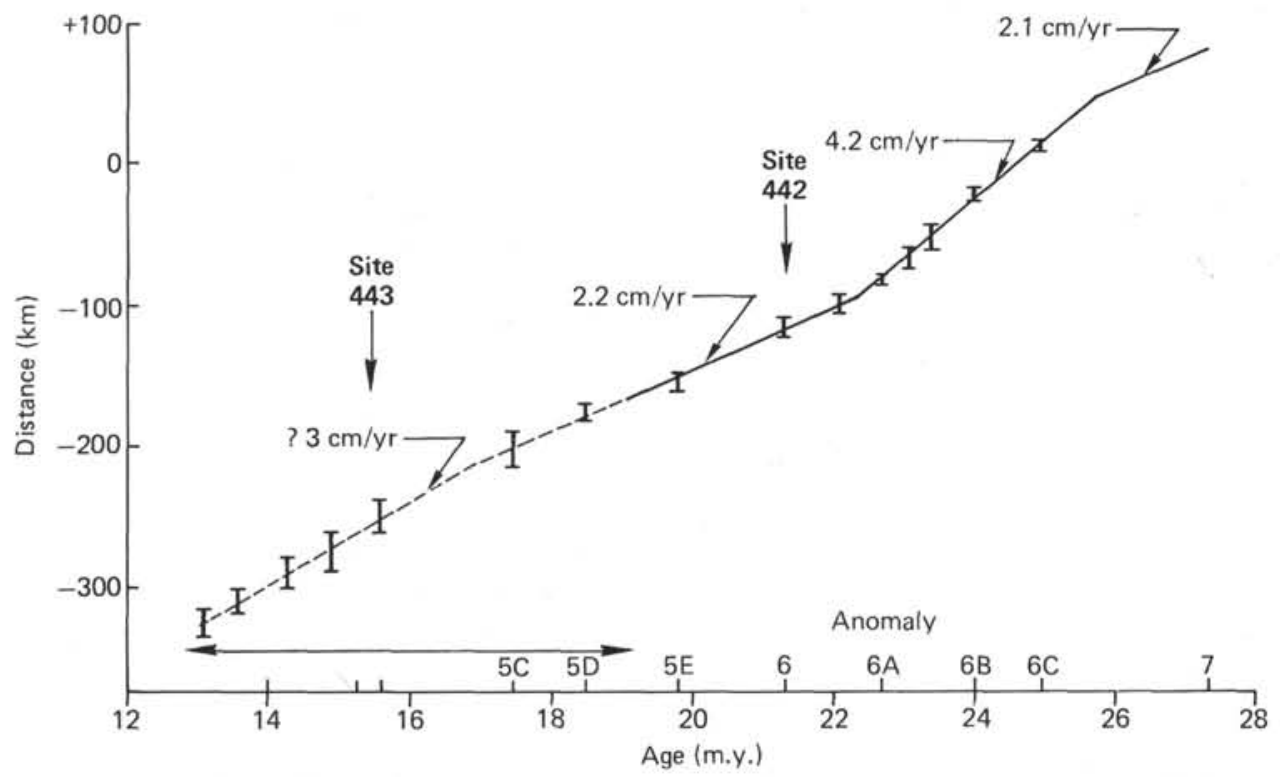

Figure 22. Magnetic ages of two sites according to a single-limb-spreading model (Watts and Weissel, 1975).

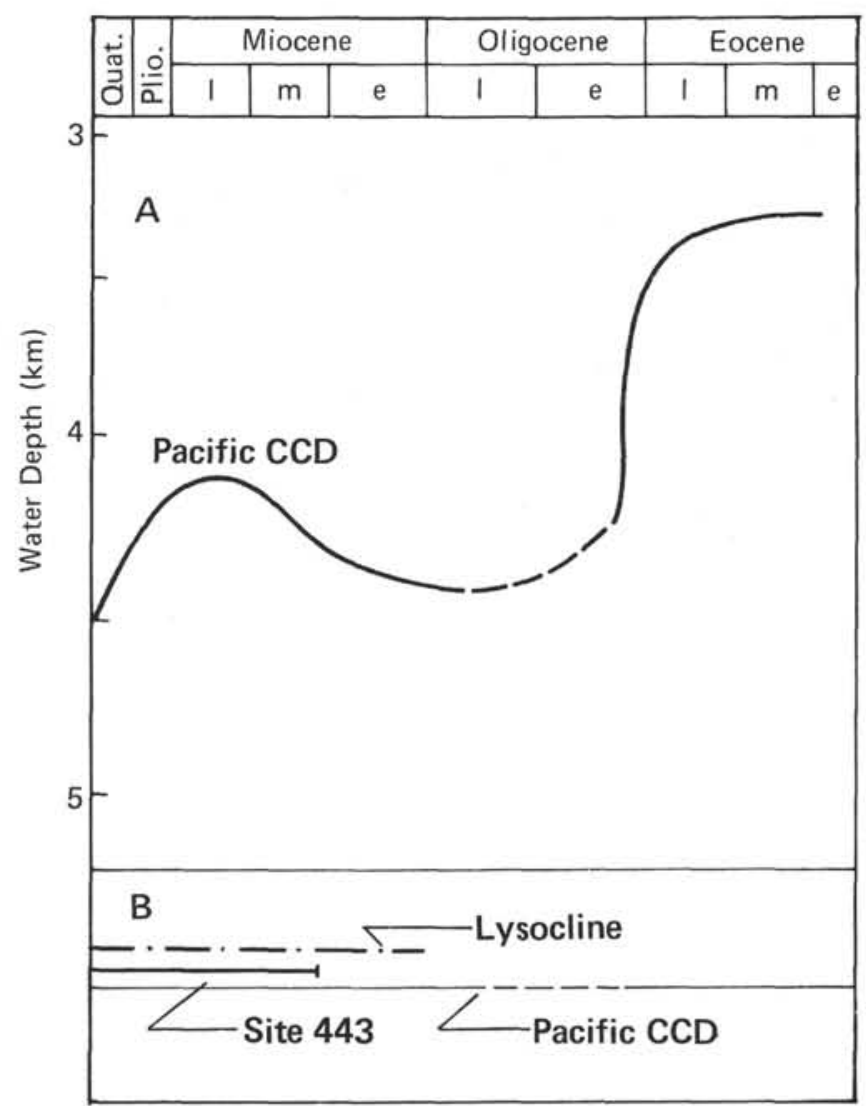

Figure 23. A. General curve showing estimated water depth of CCD in Pacific Ocean lafter van Andel et al., 1975, p. 47, fig. 29). B. Relative depth of deposition at Site 443 compared to CCD curve for Pacific Ocean. 


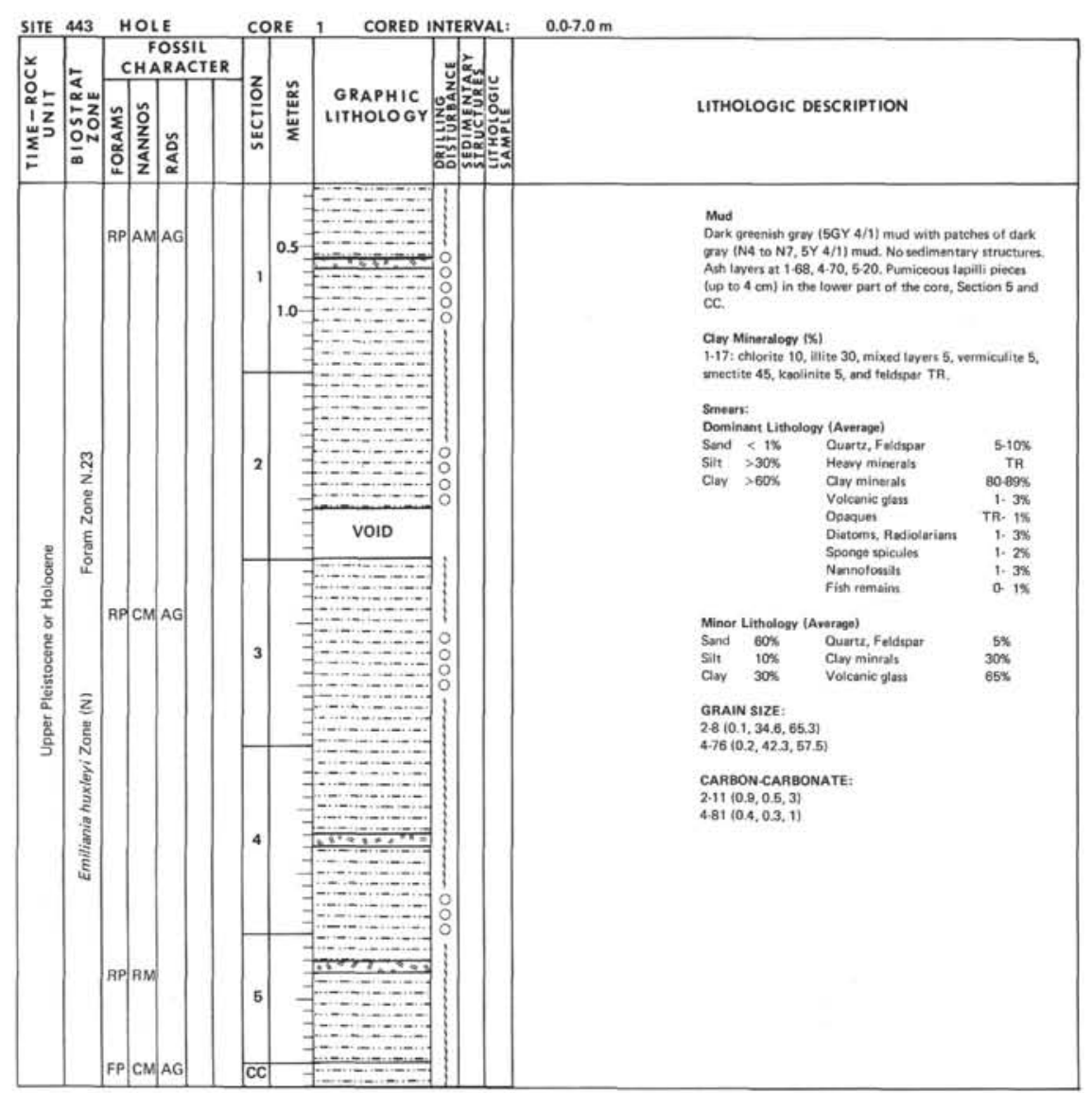

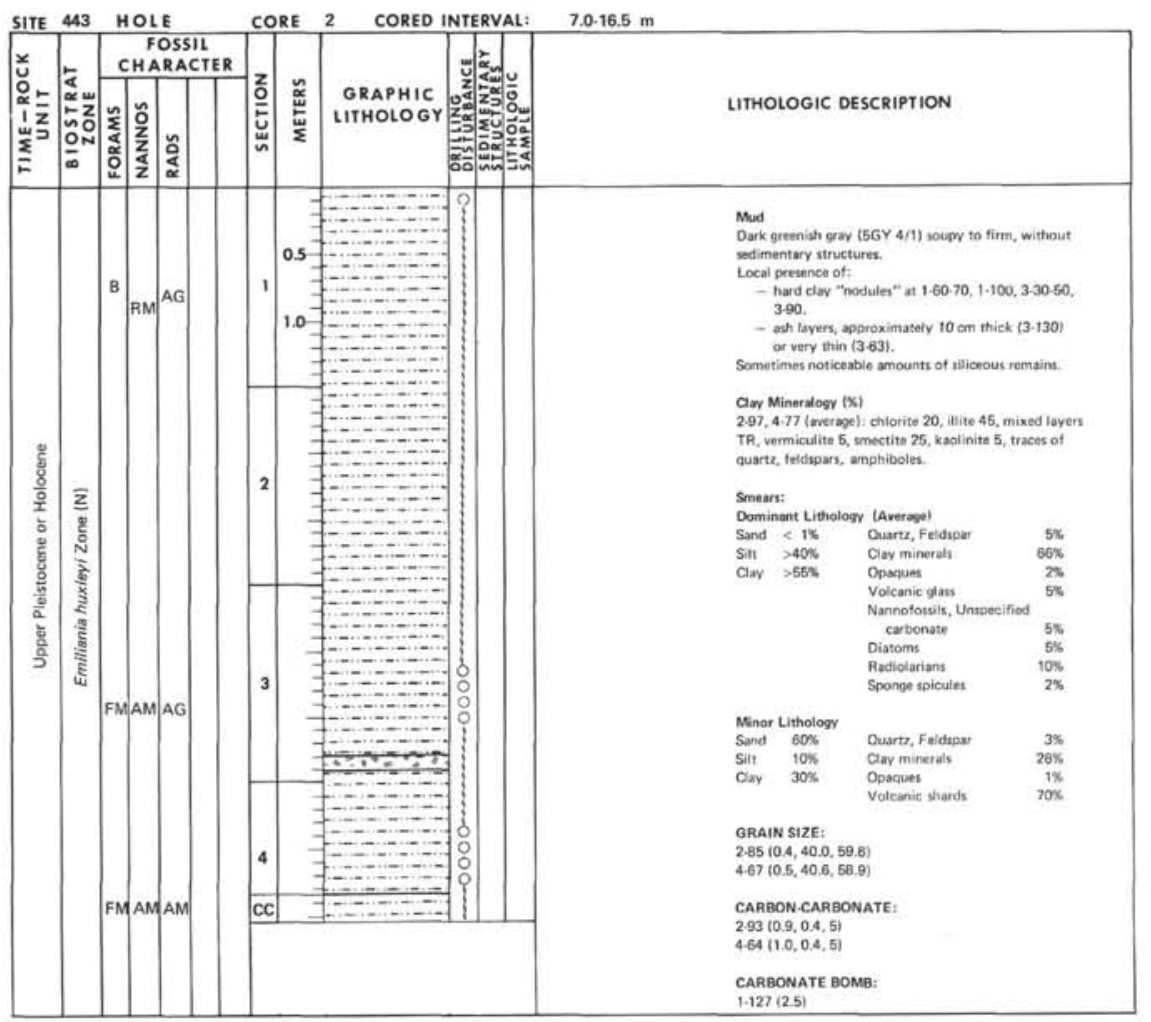




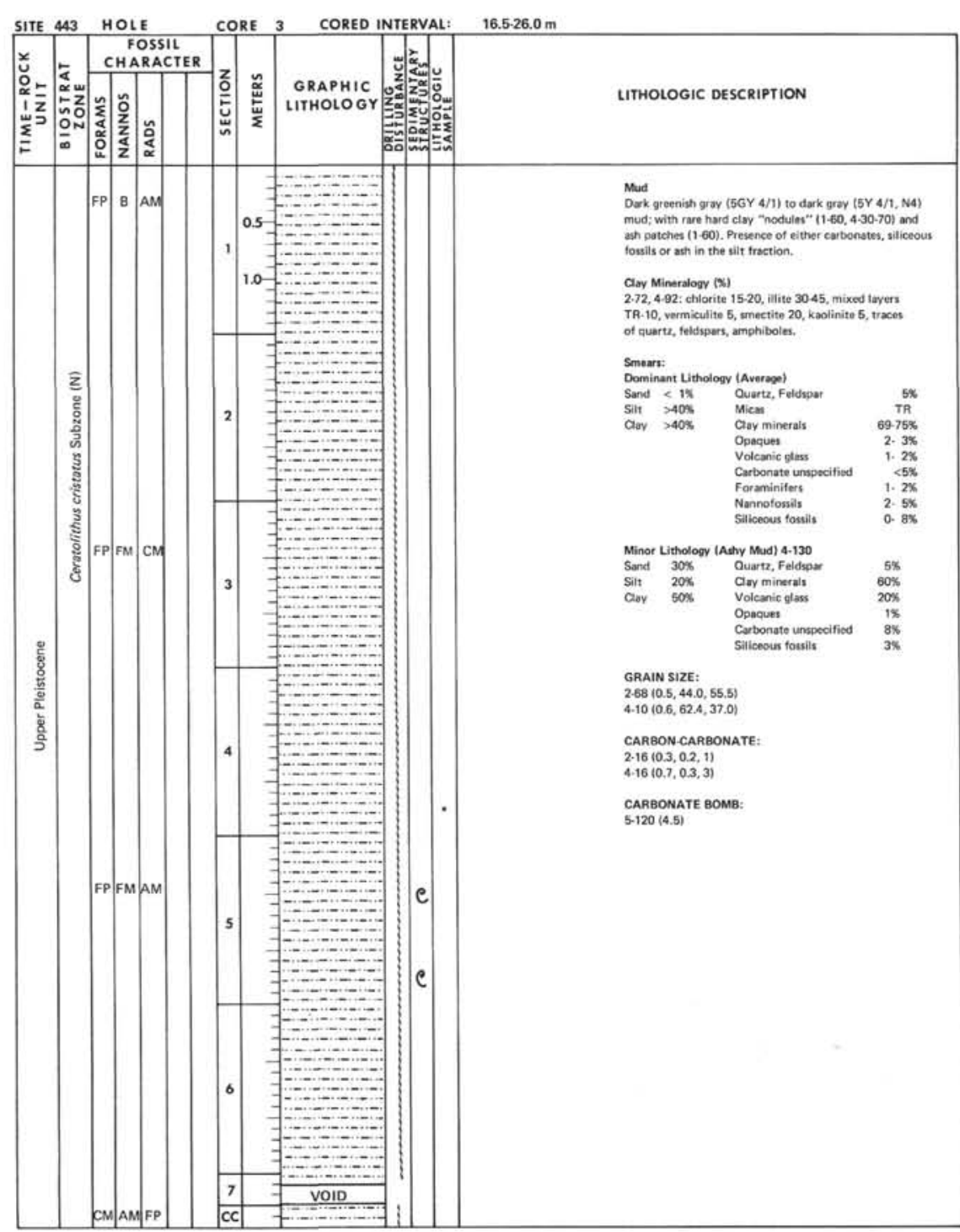

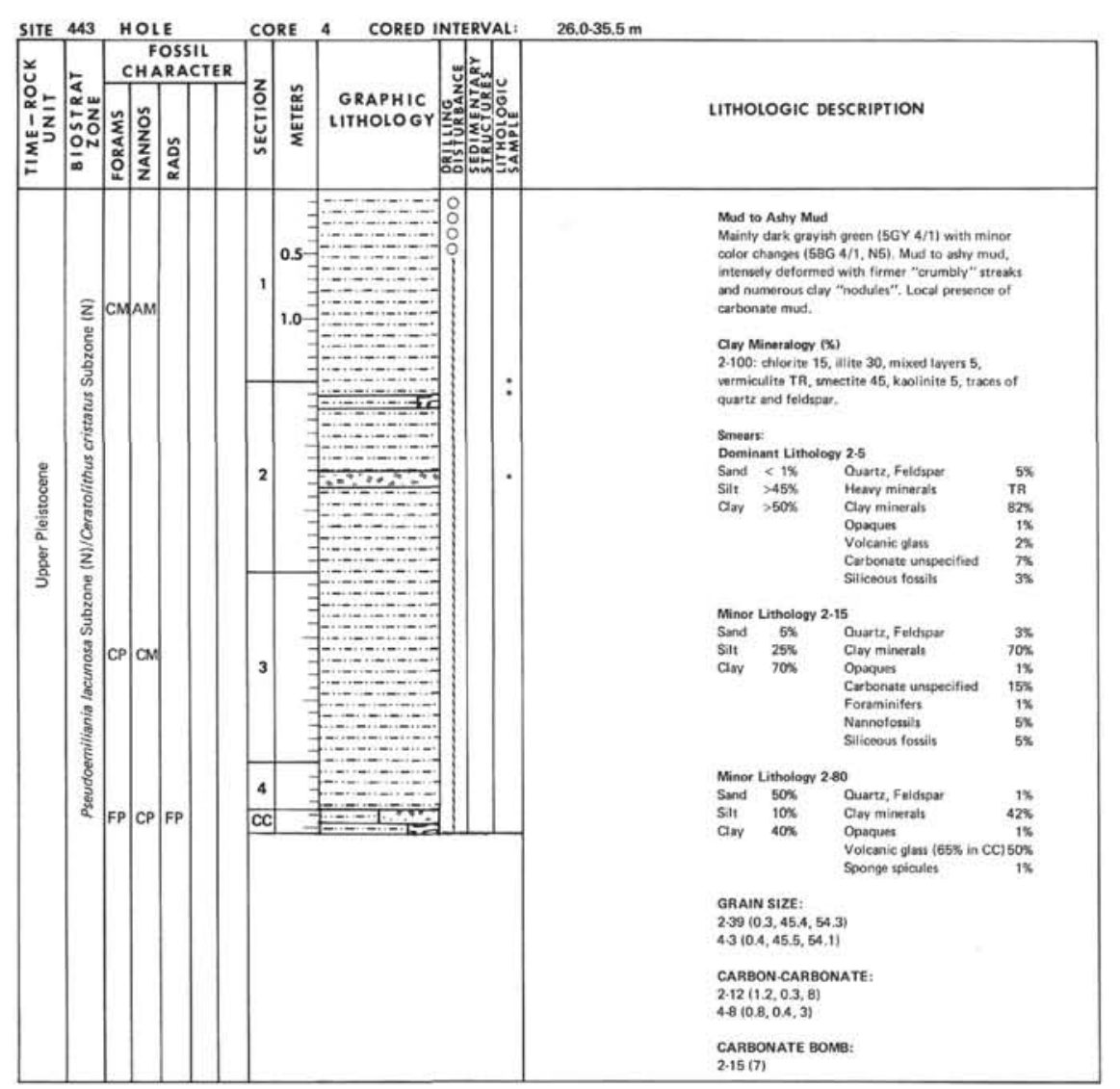




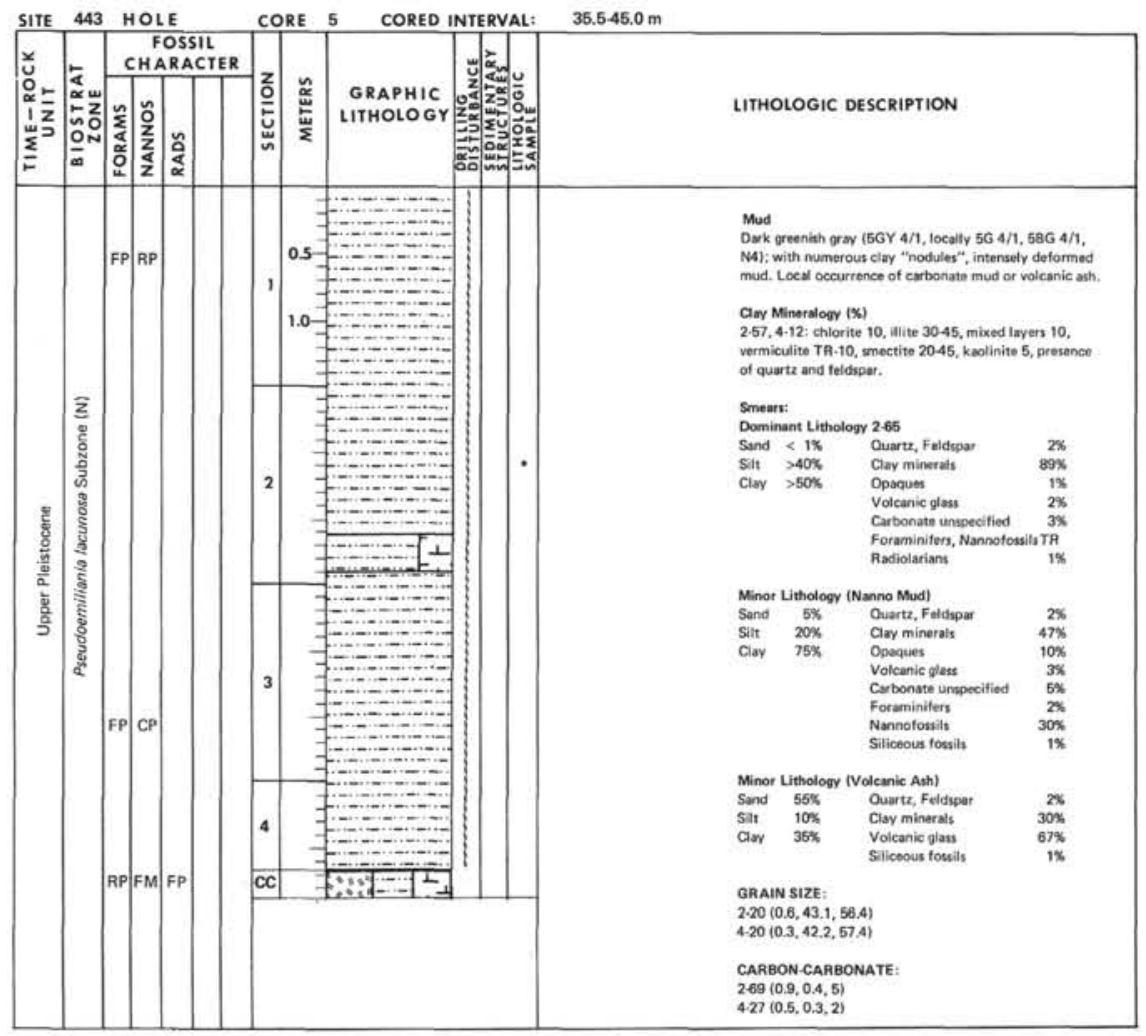

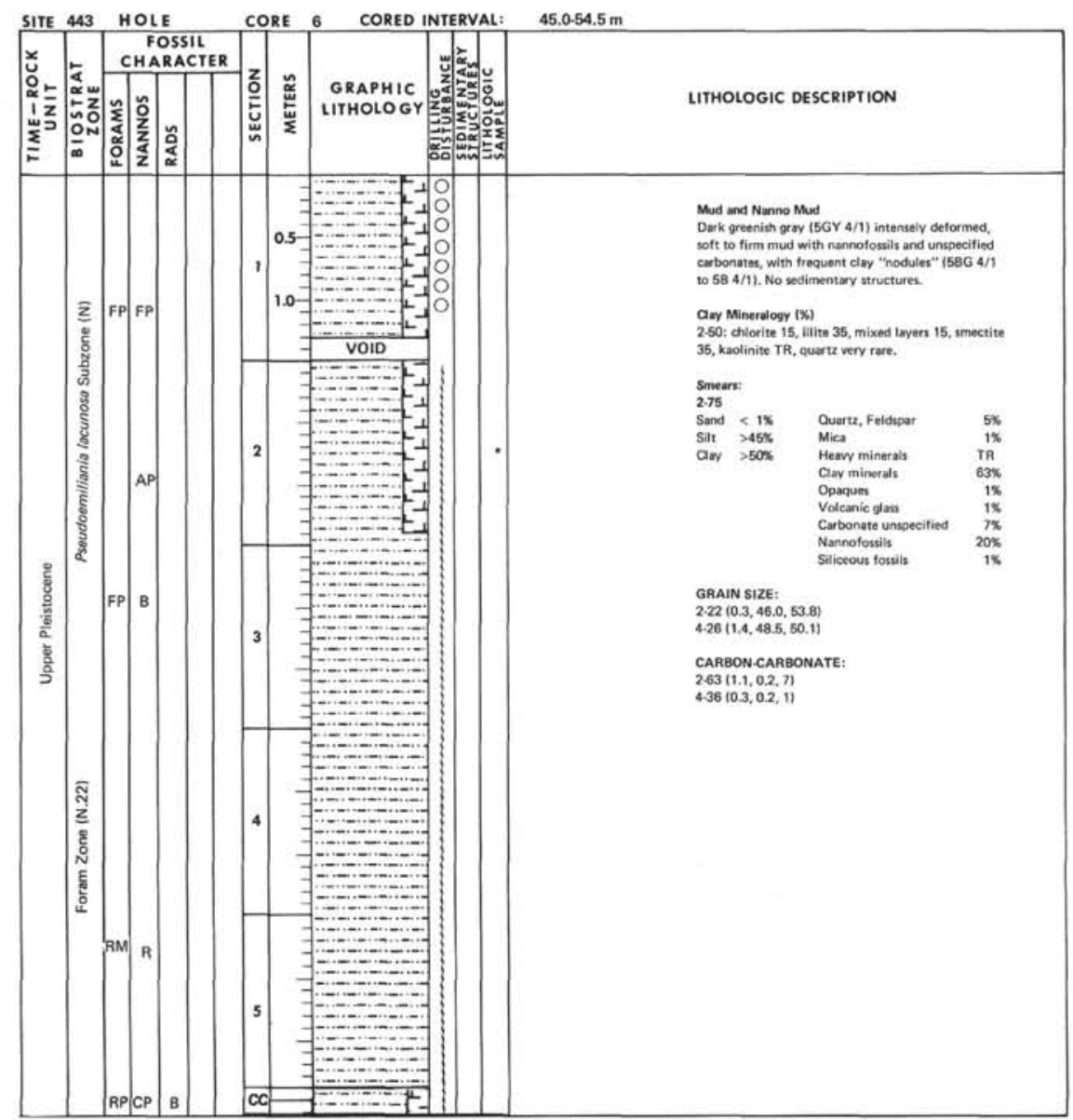



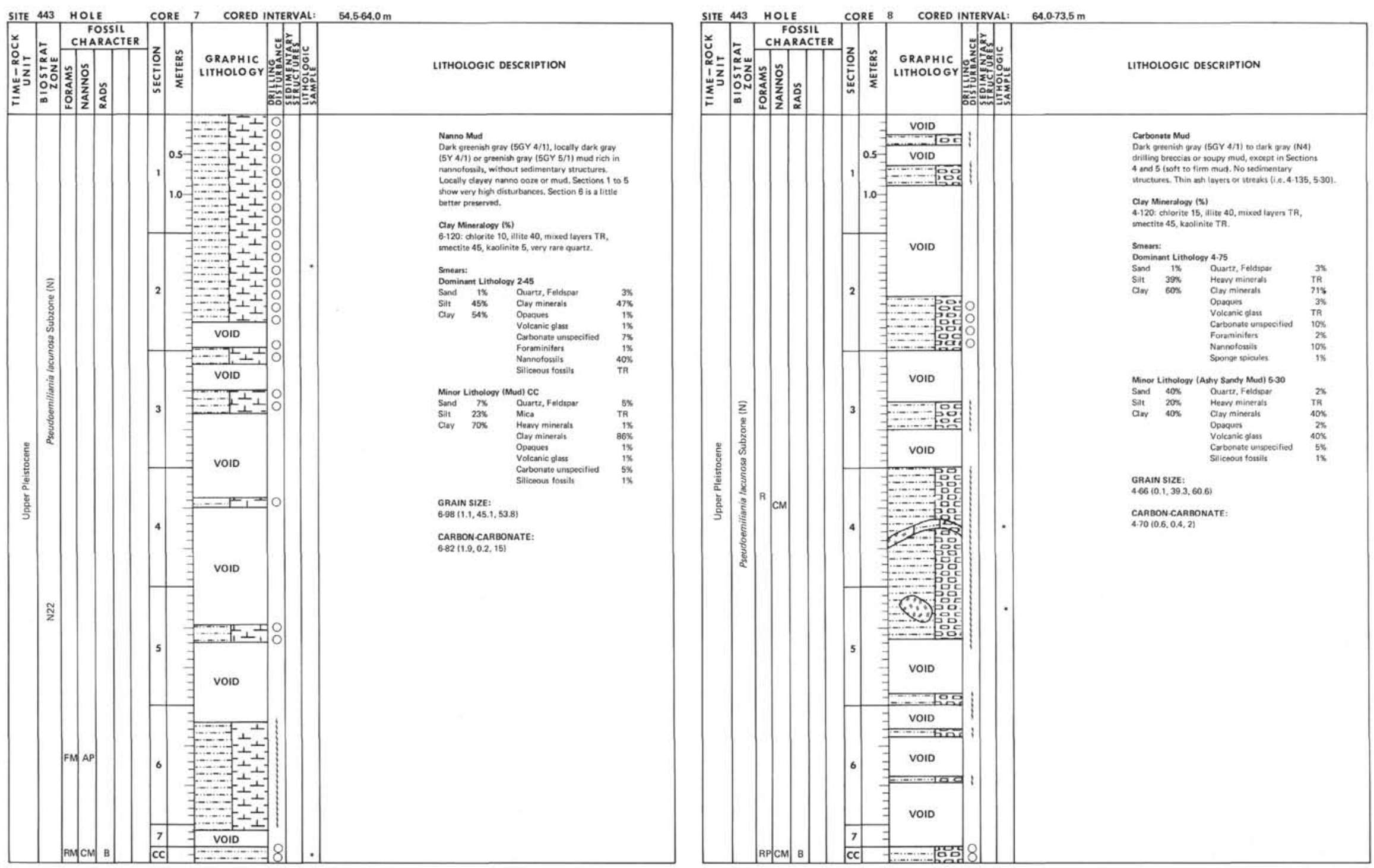


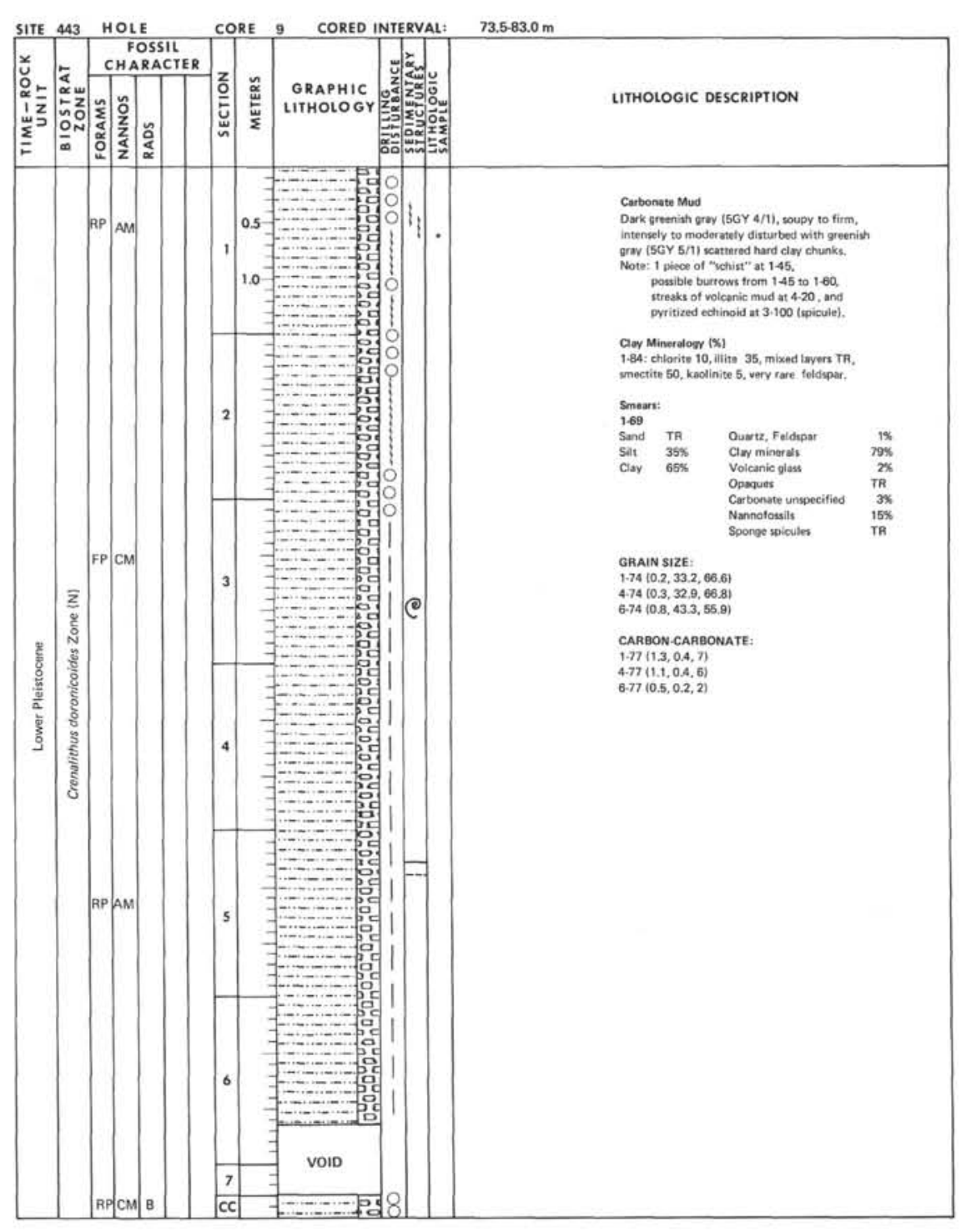

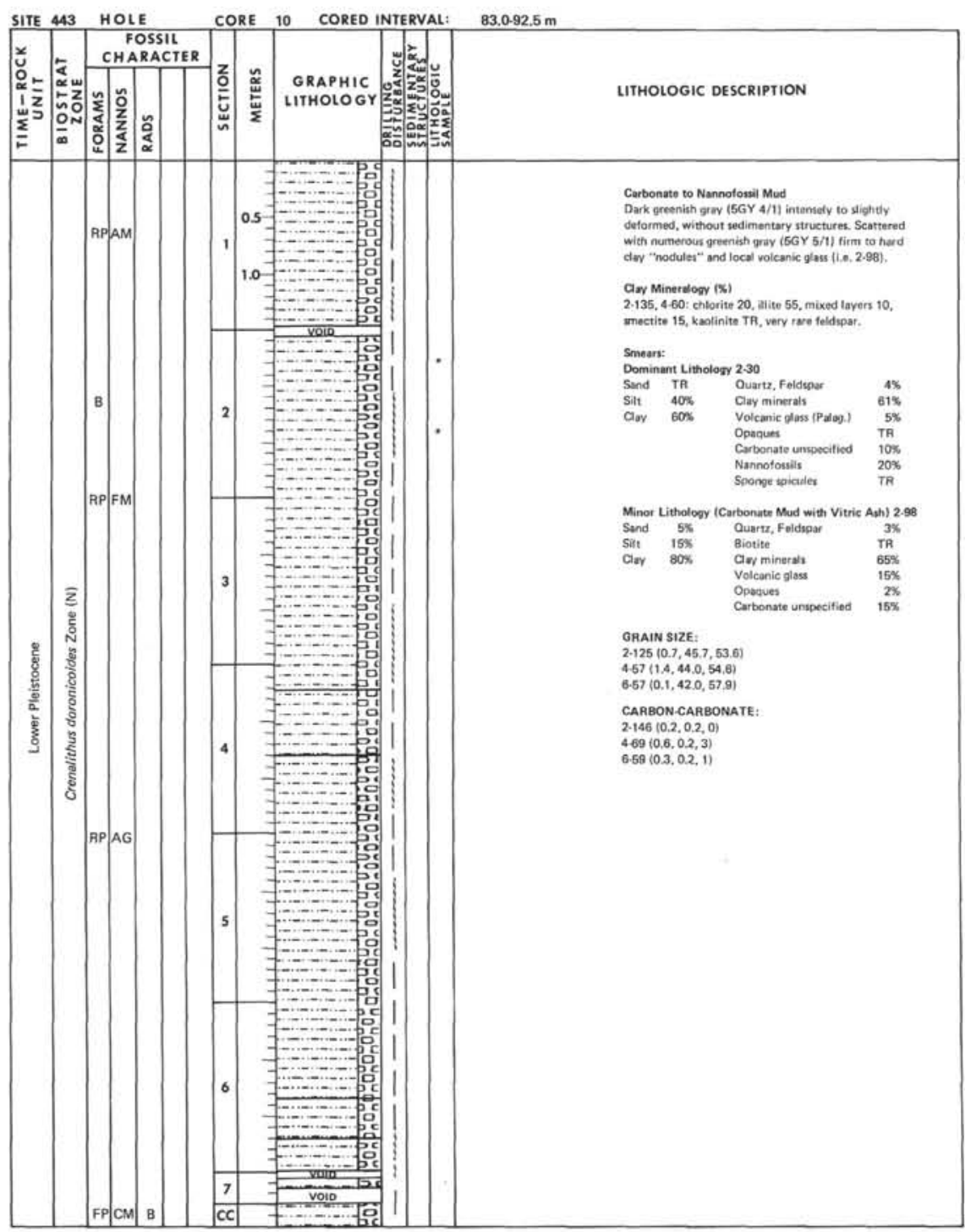




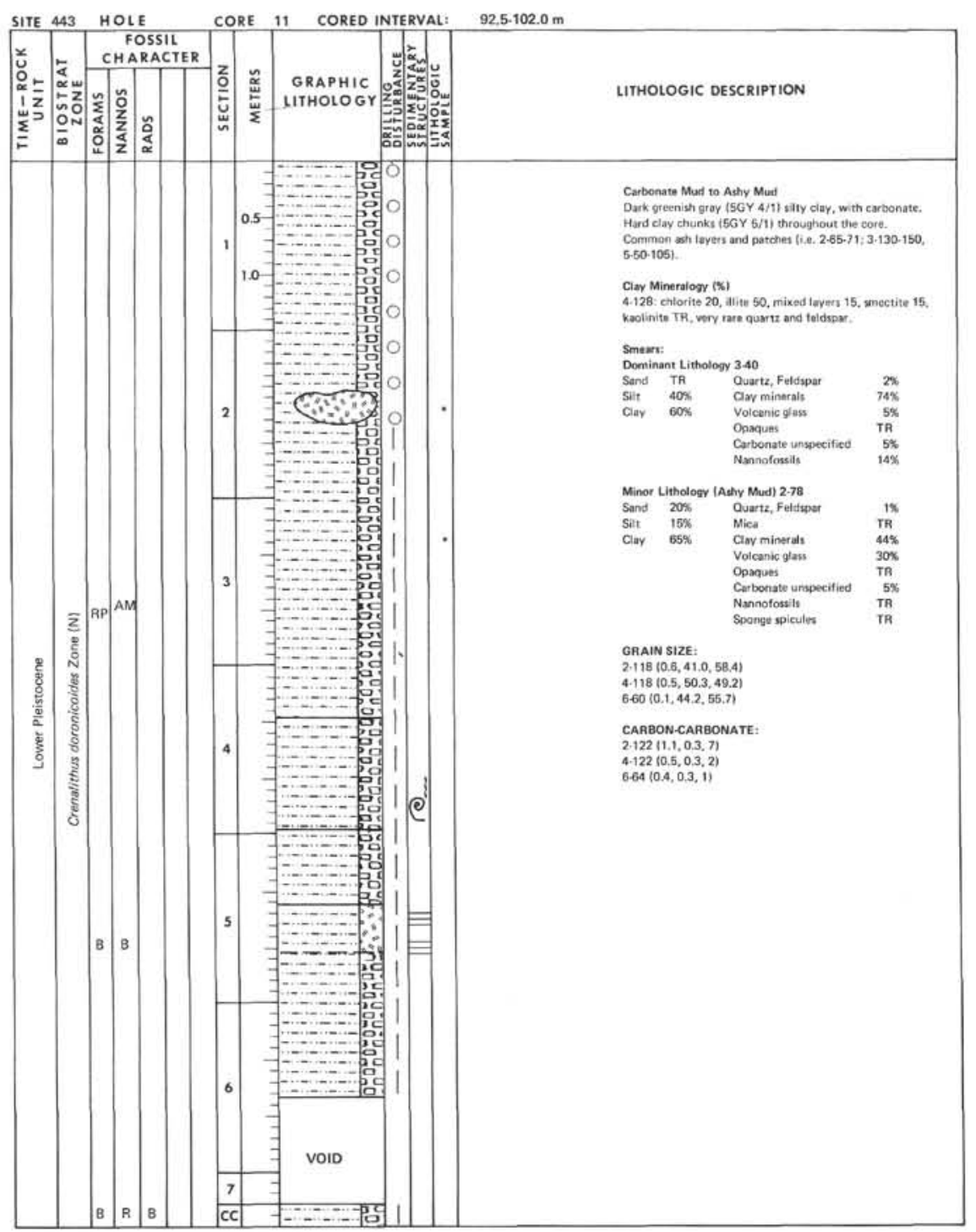

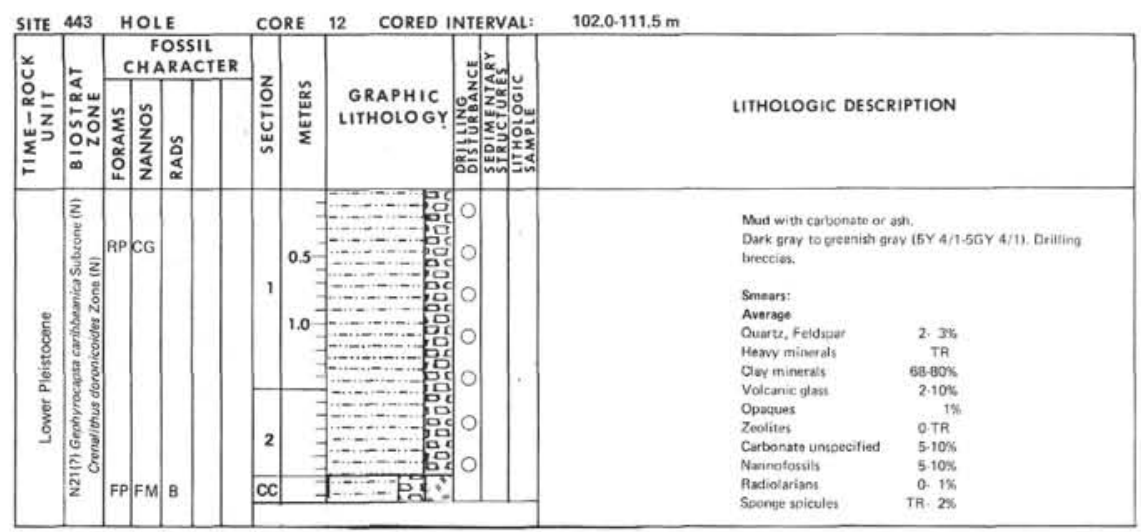

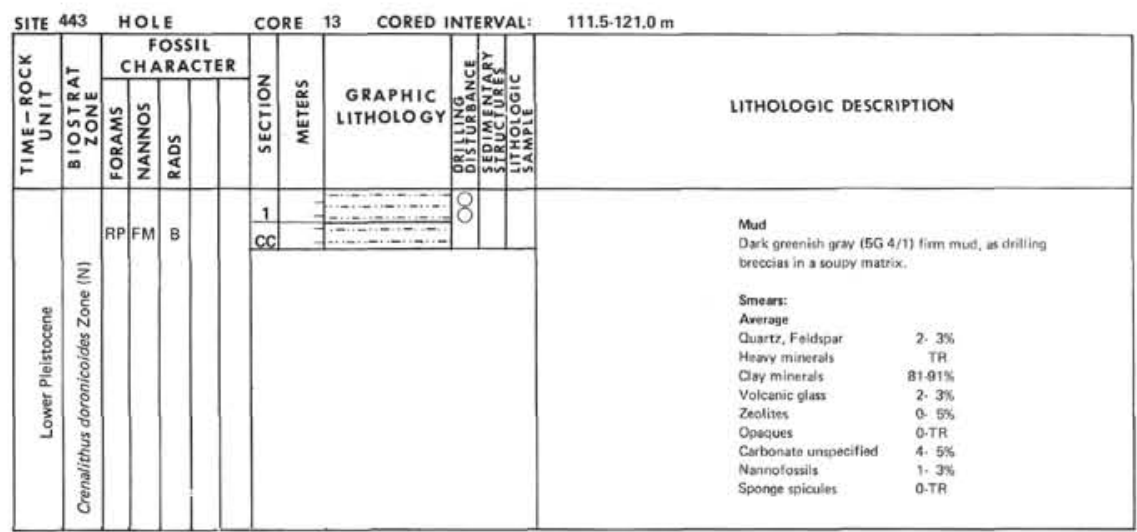




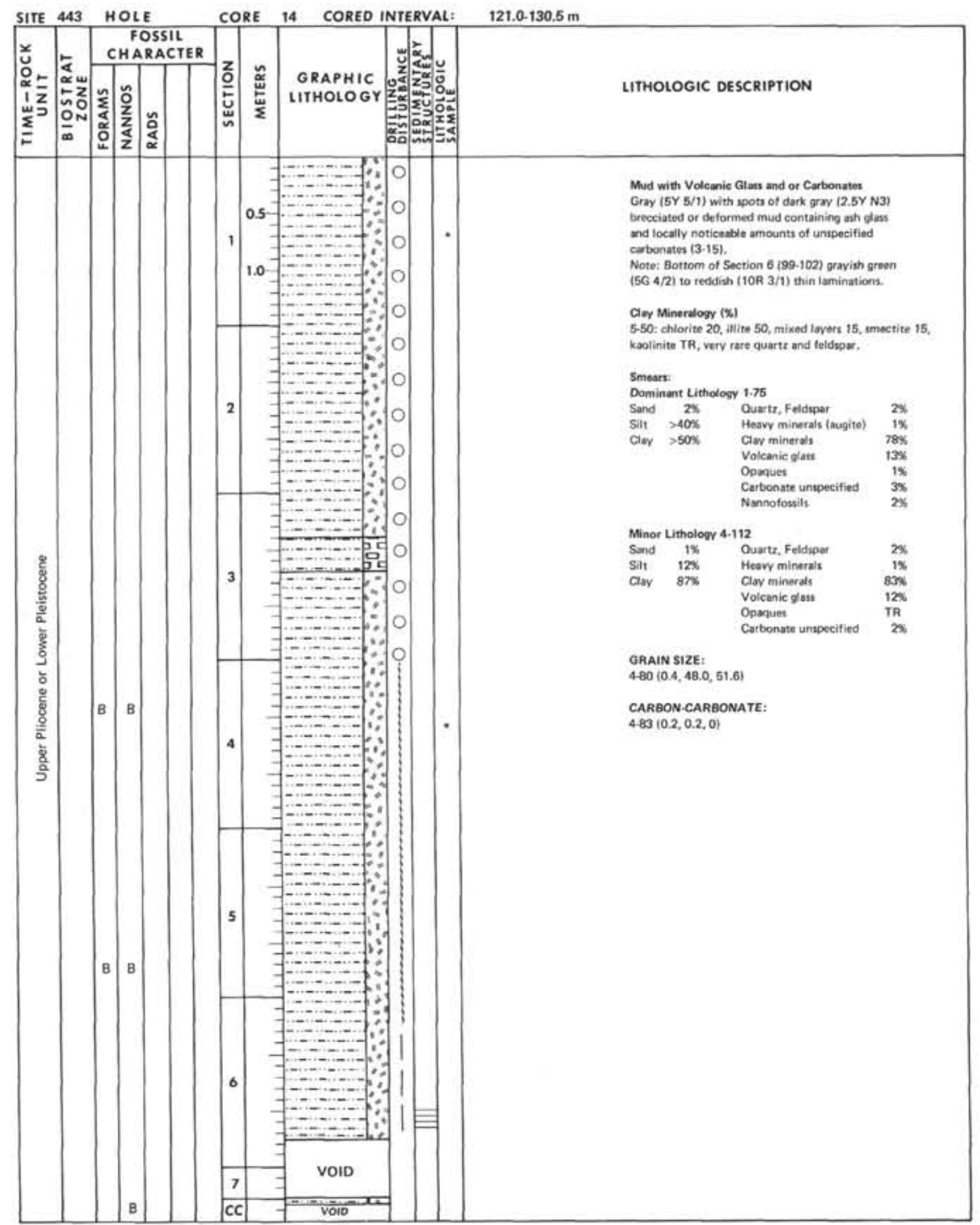

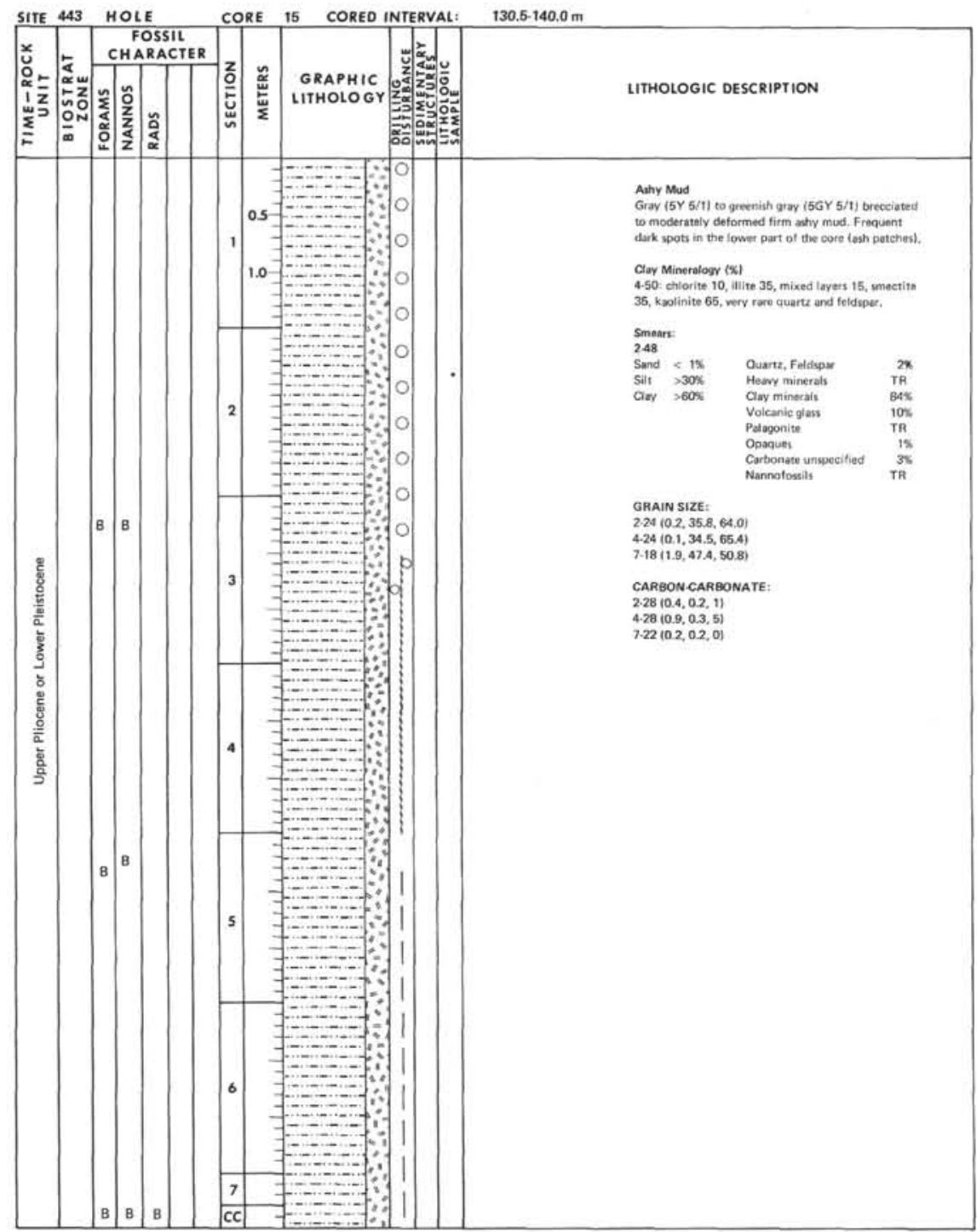




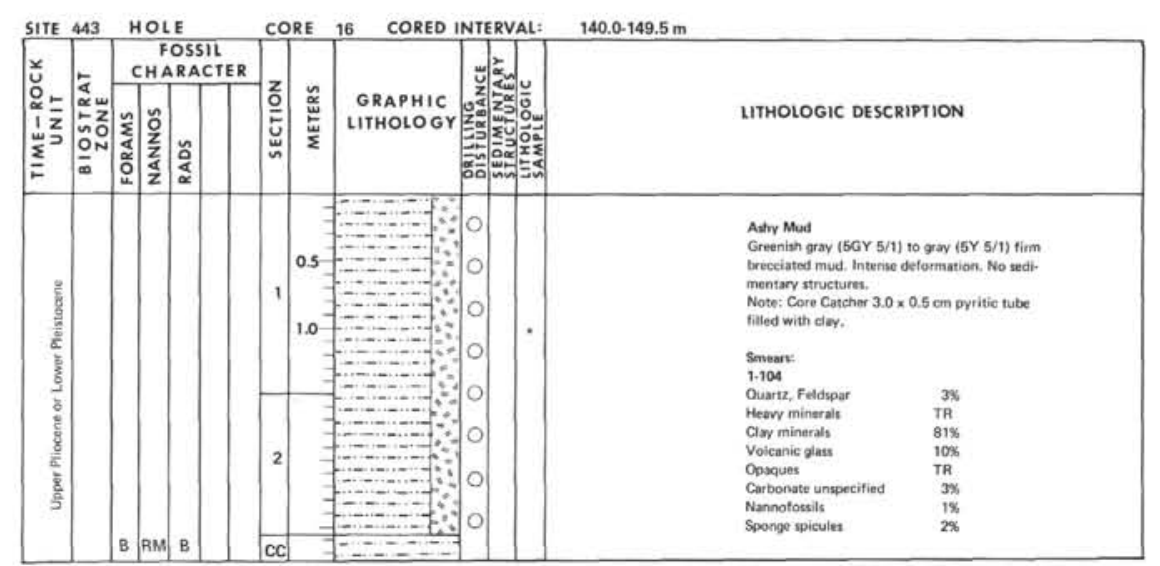

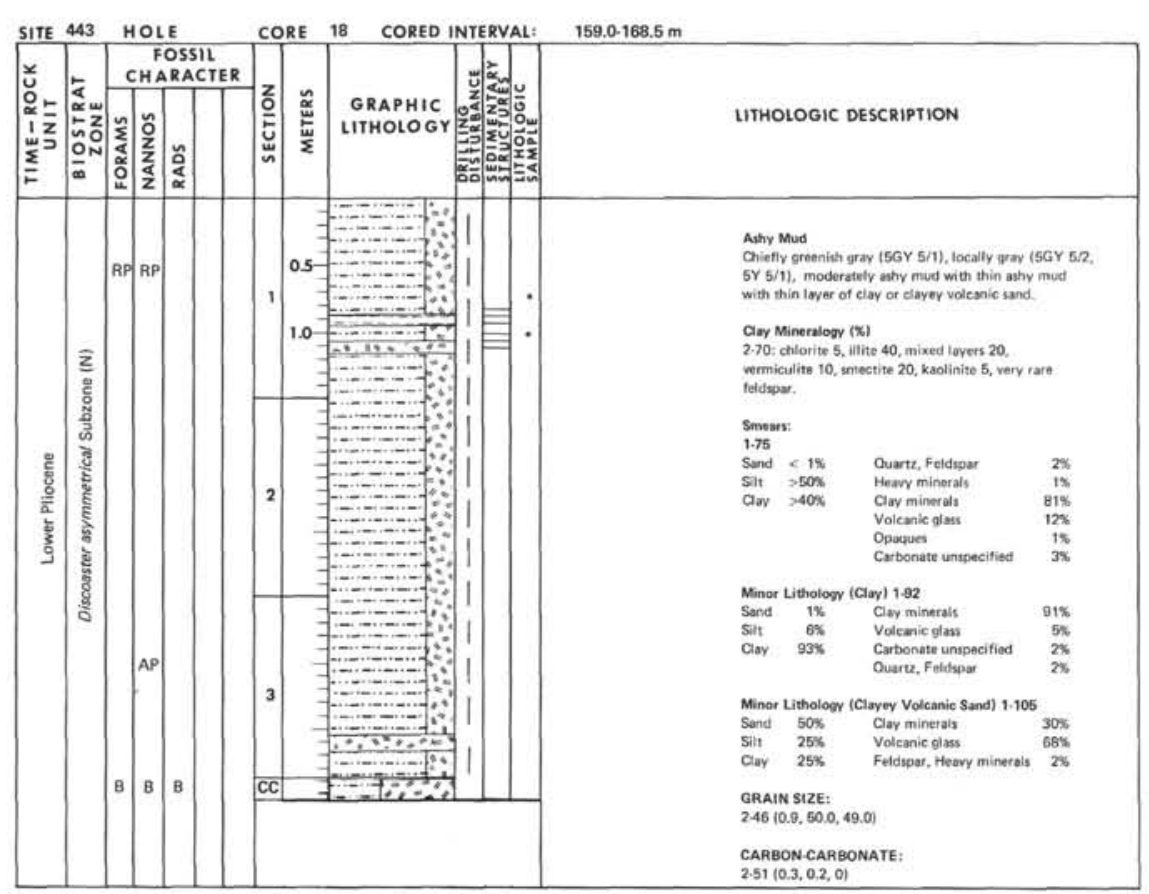

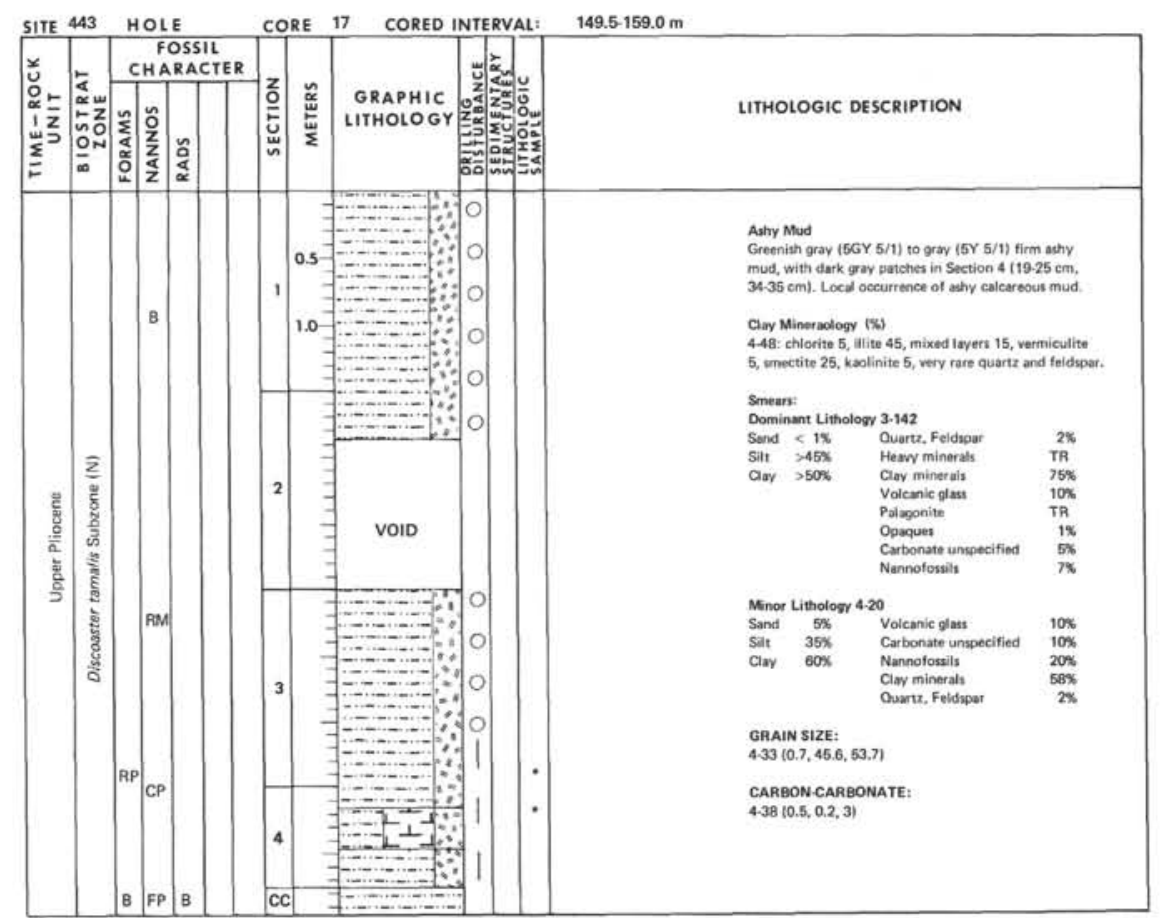

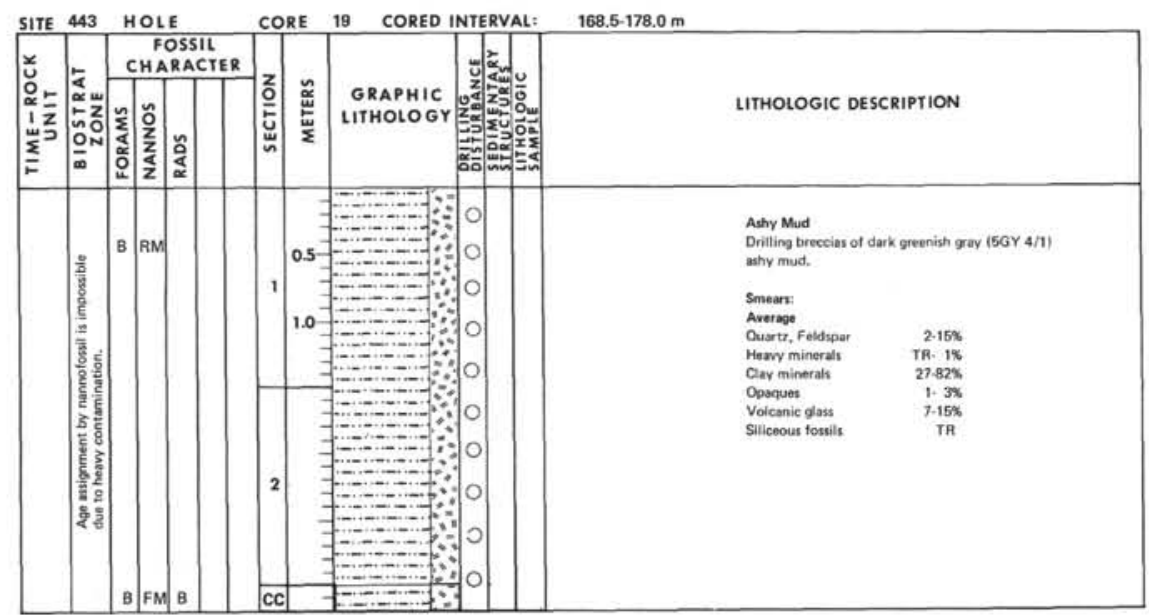



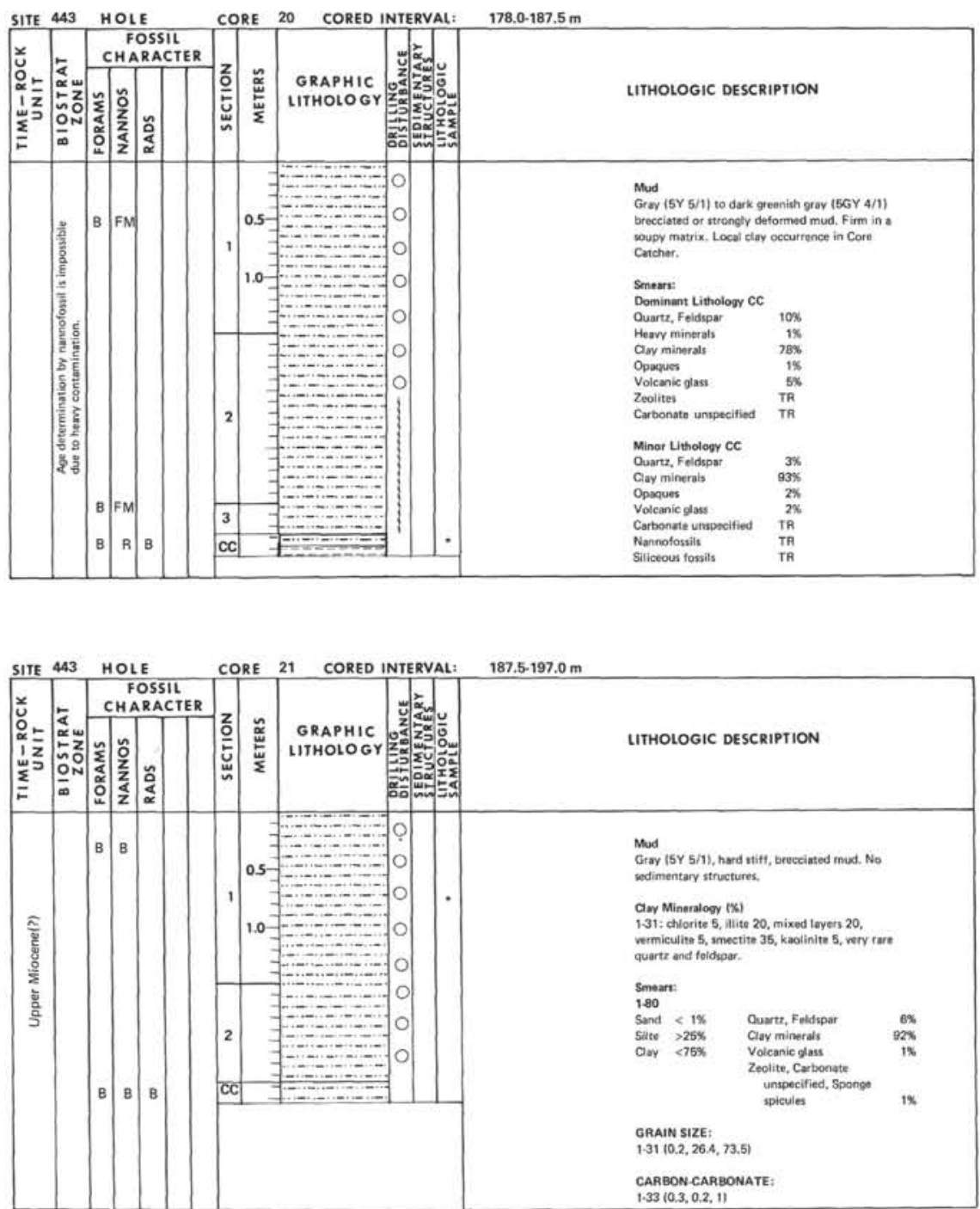

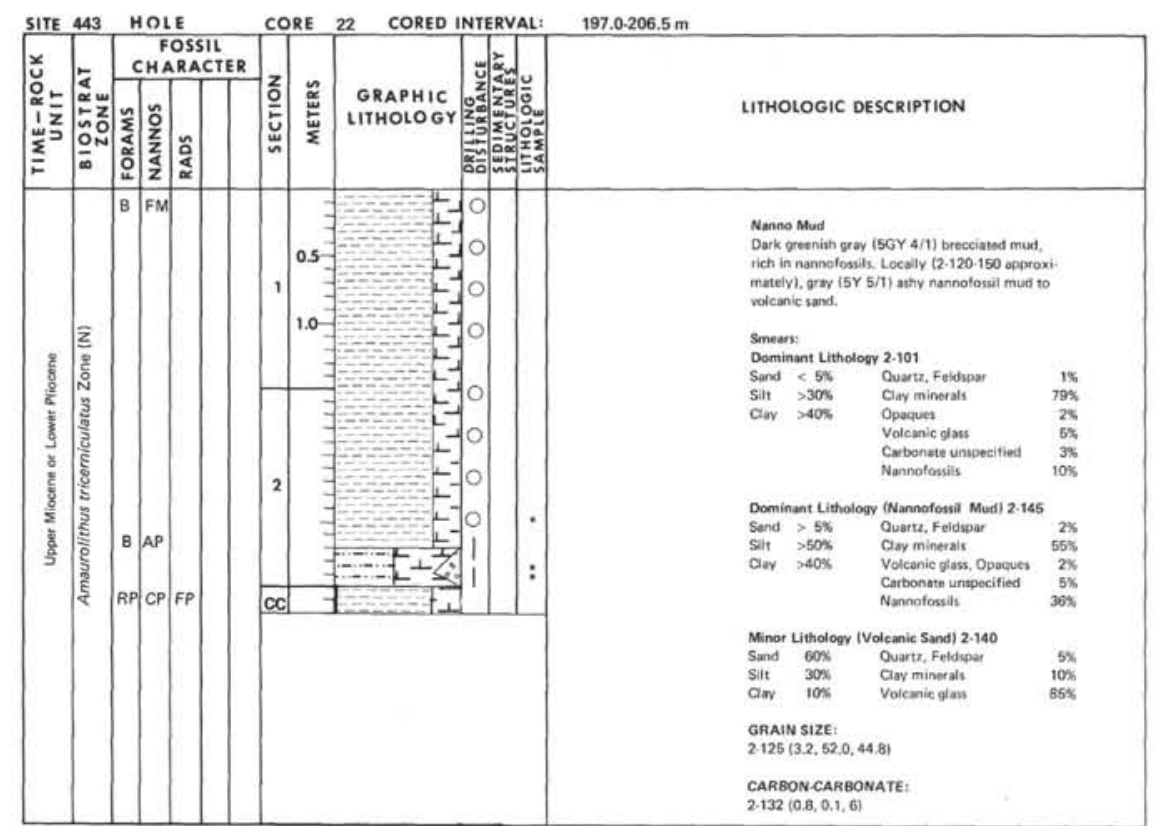




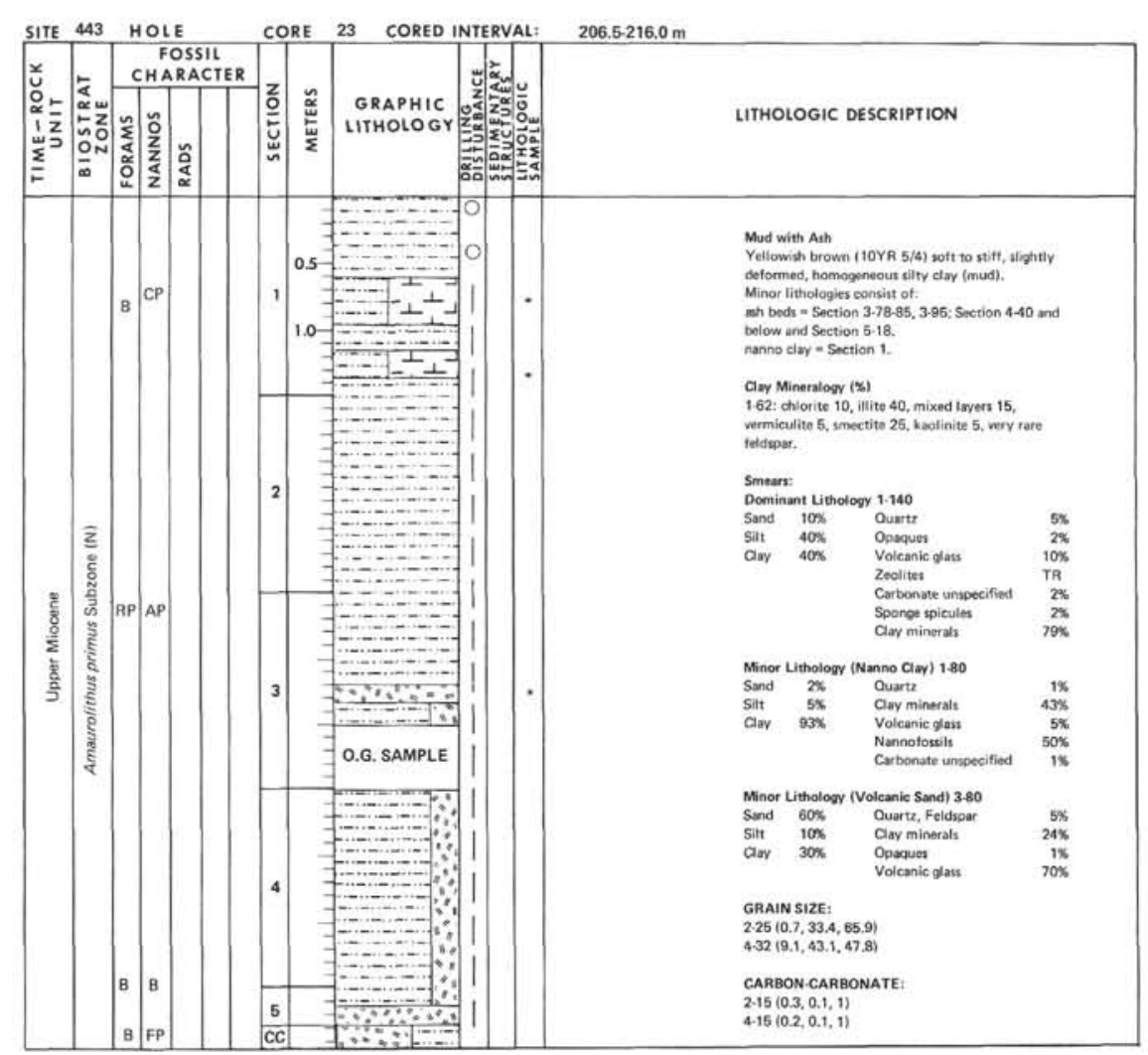

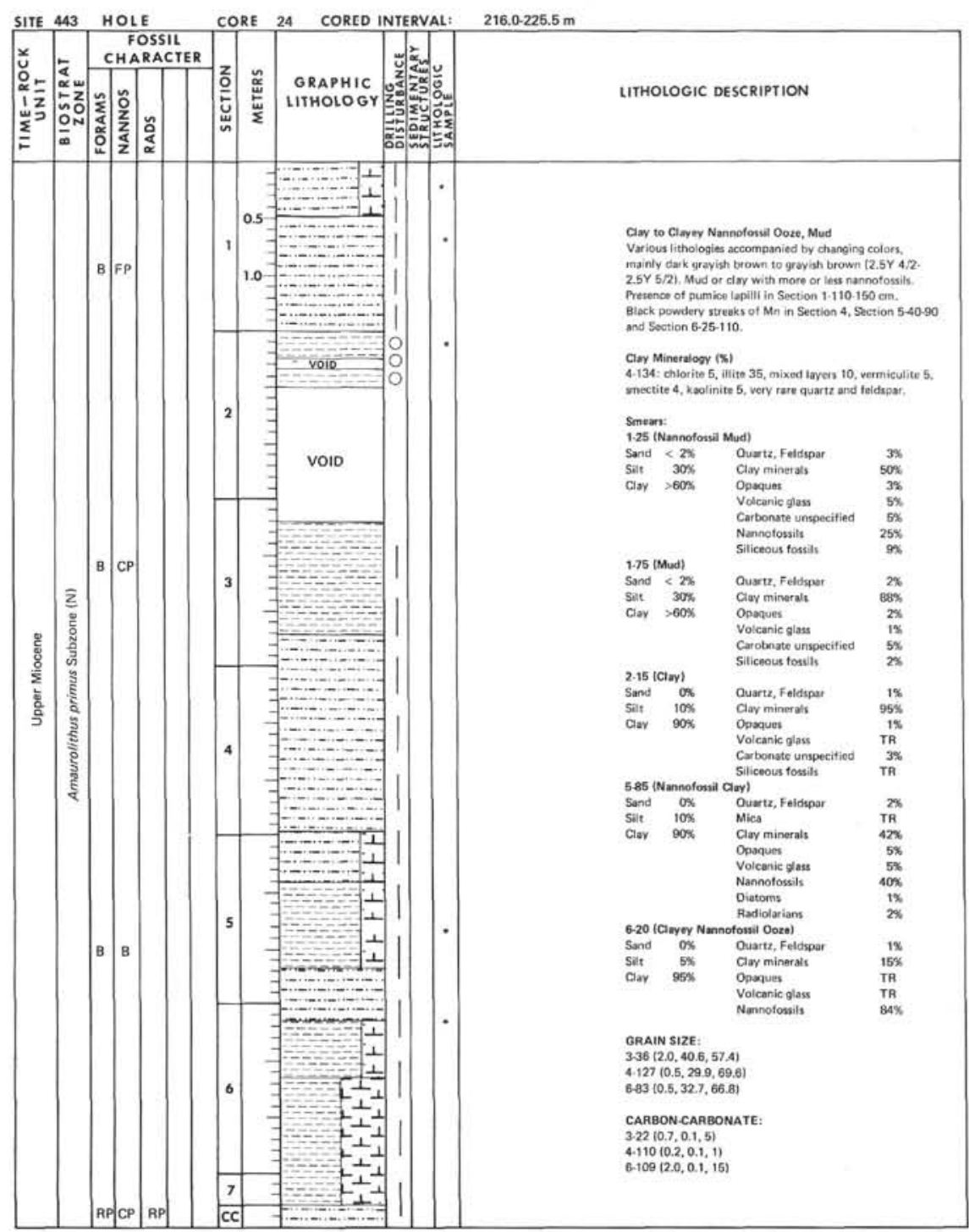




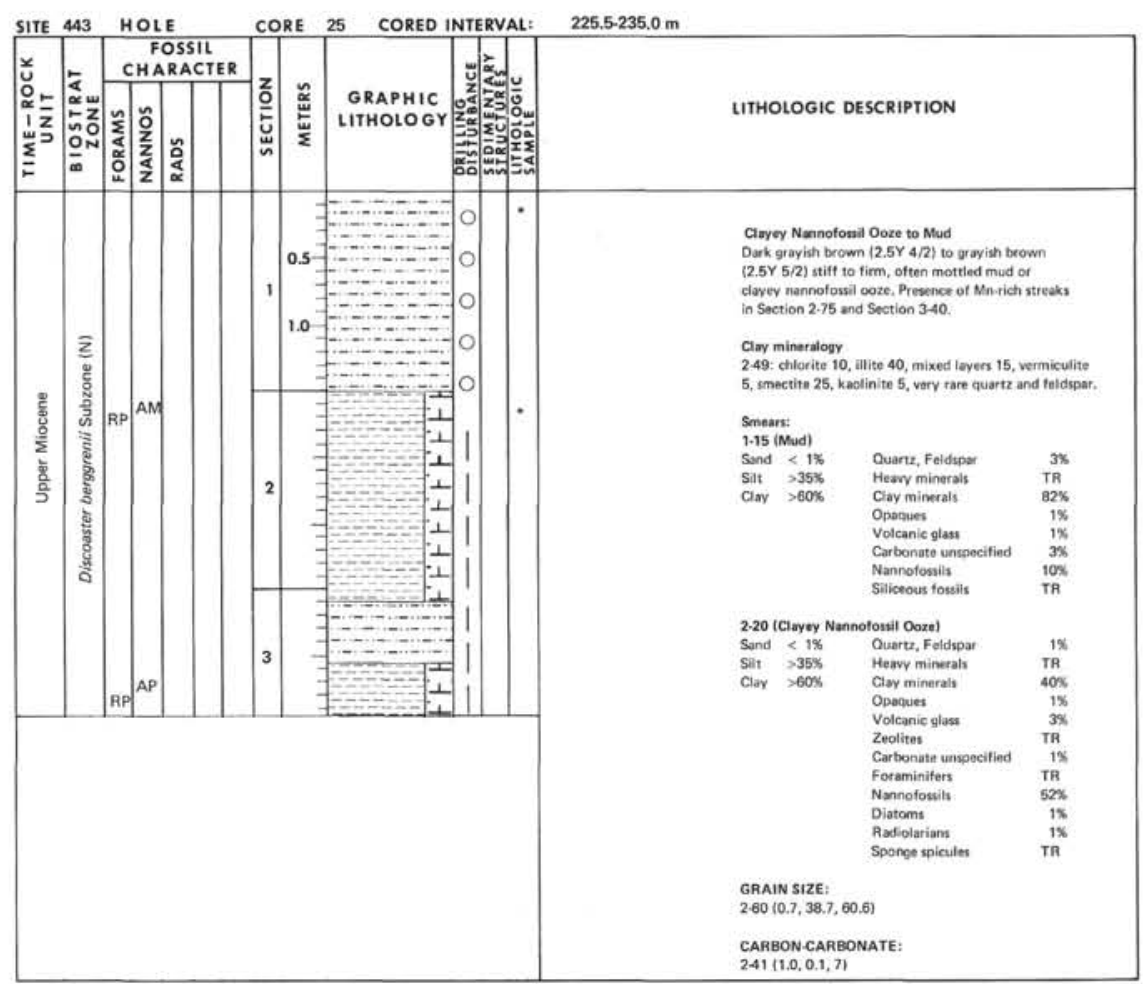

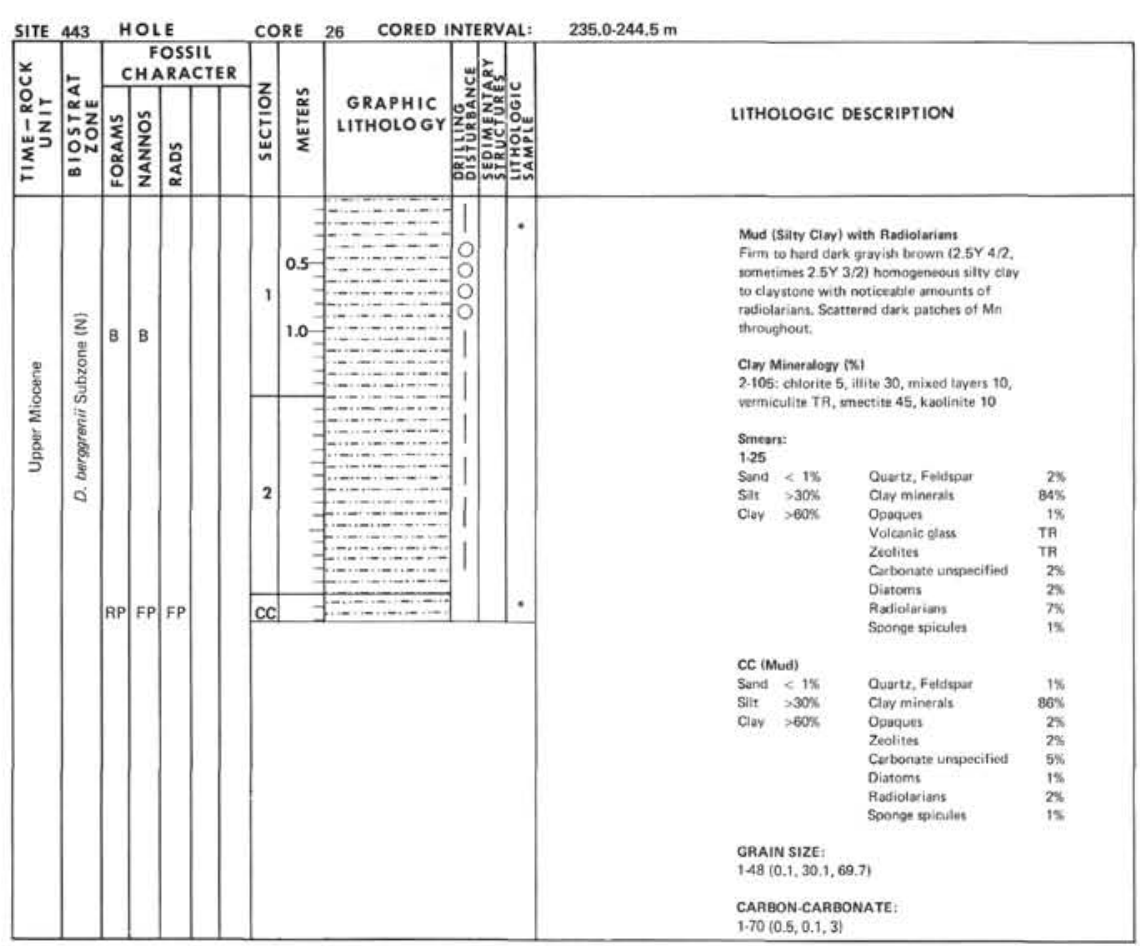




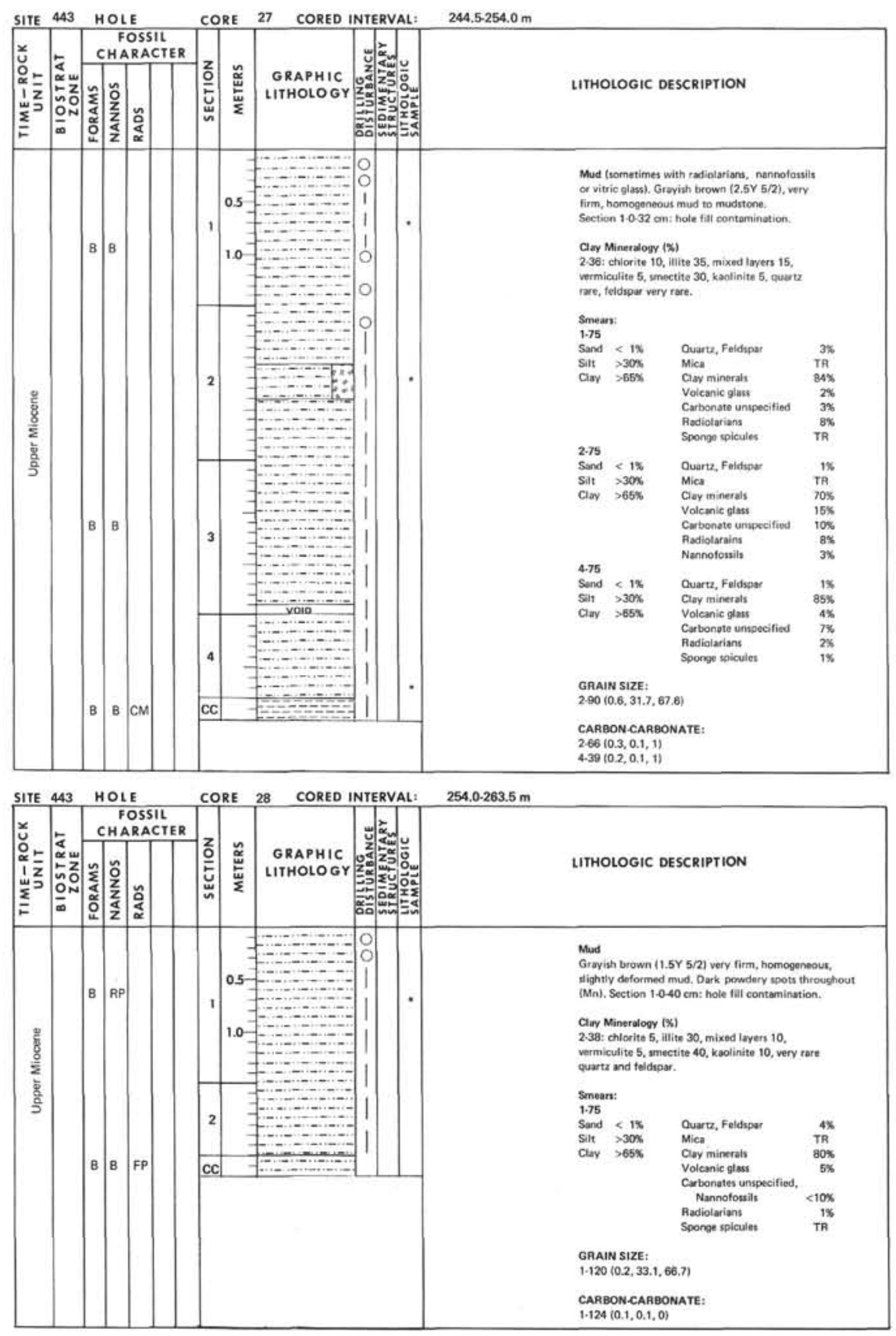

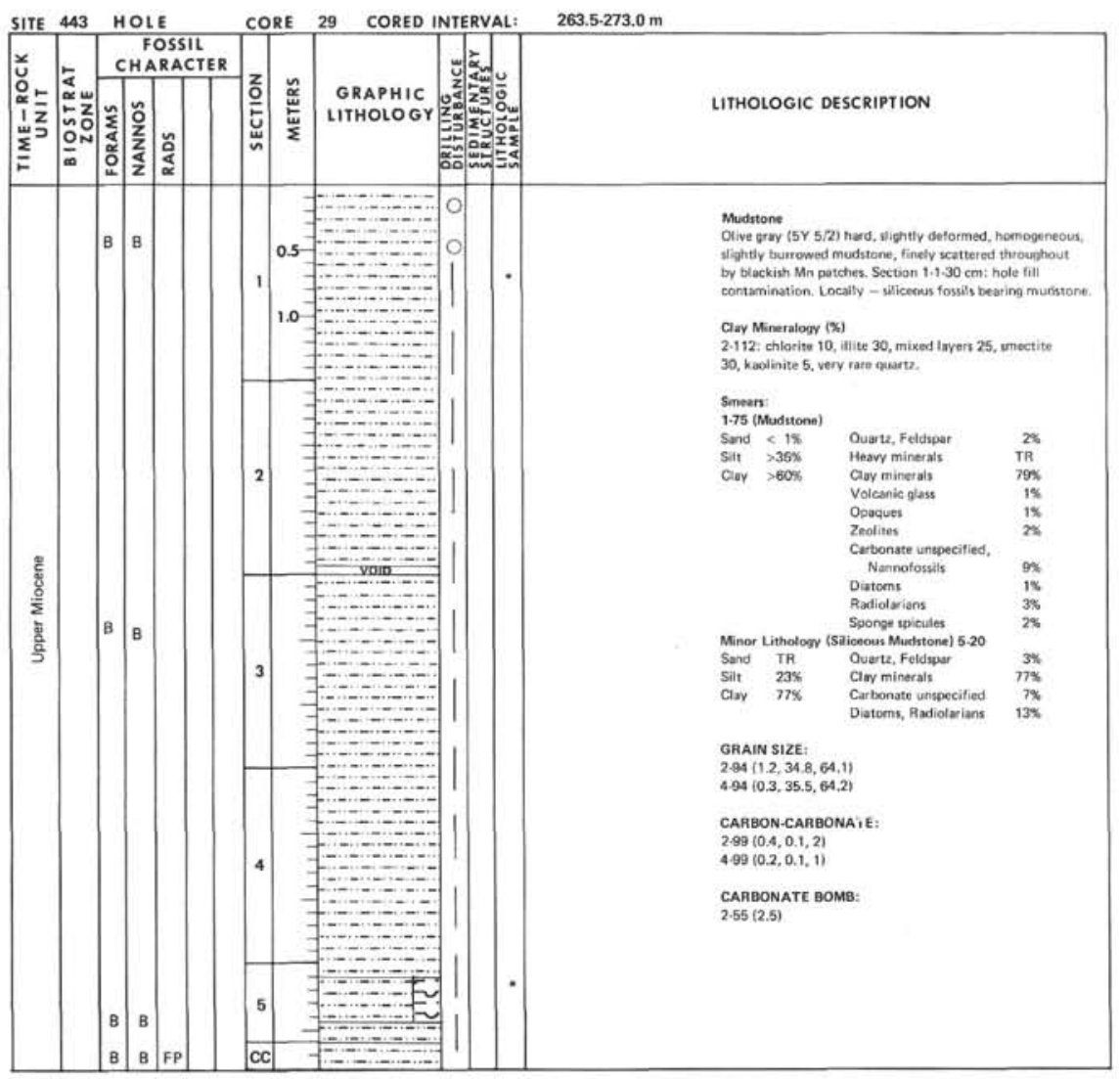




\begin{tabular}{|l|l|l|l|l|l|l|l|}
\hline \\
SITE
\end{tabular}

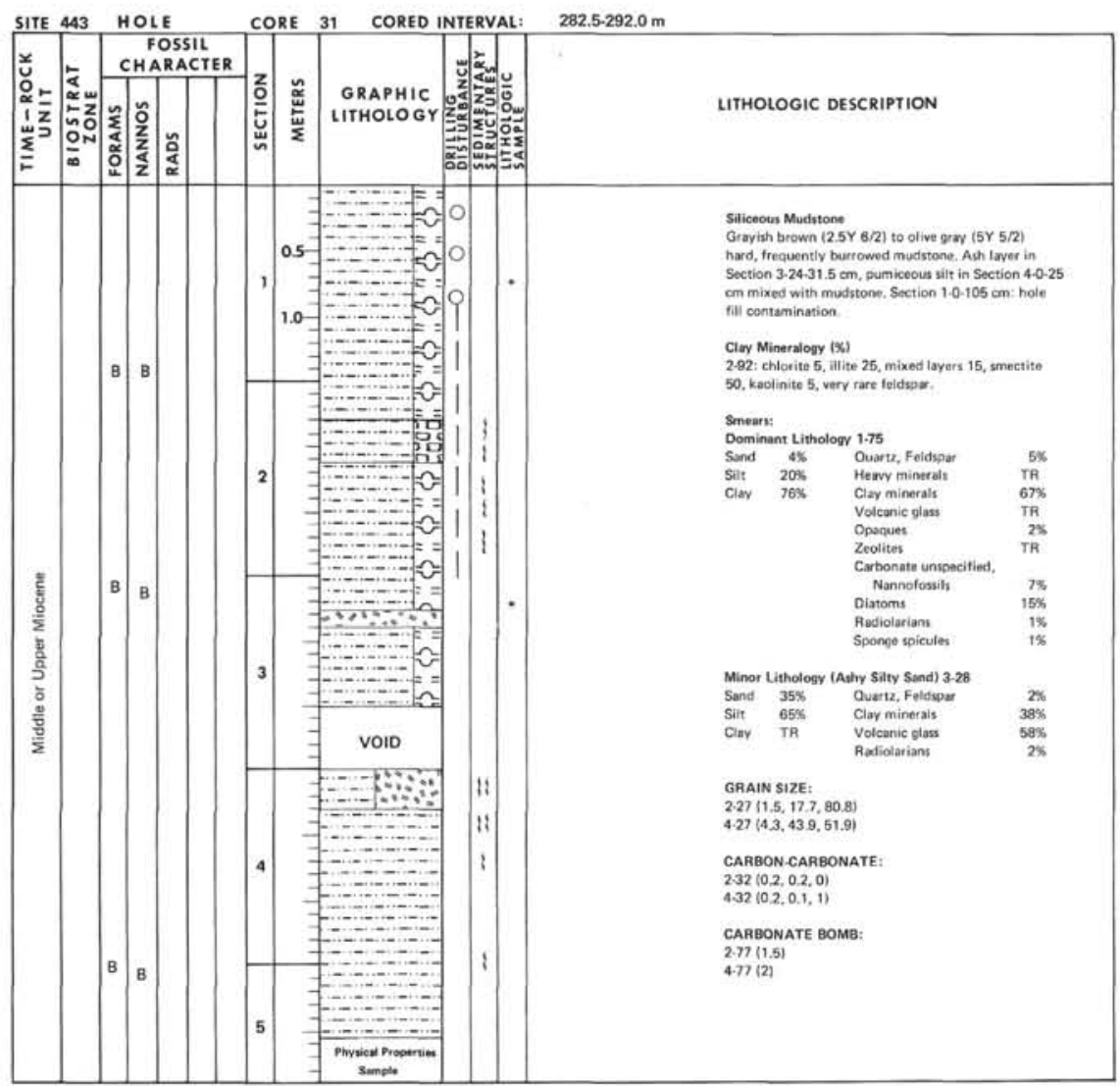




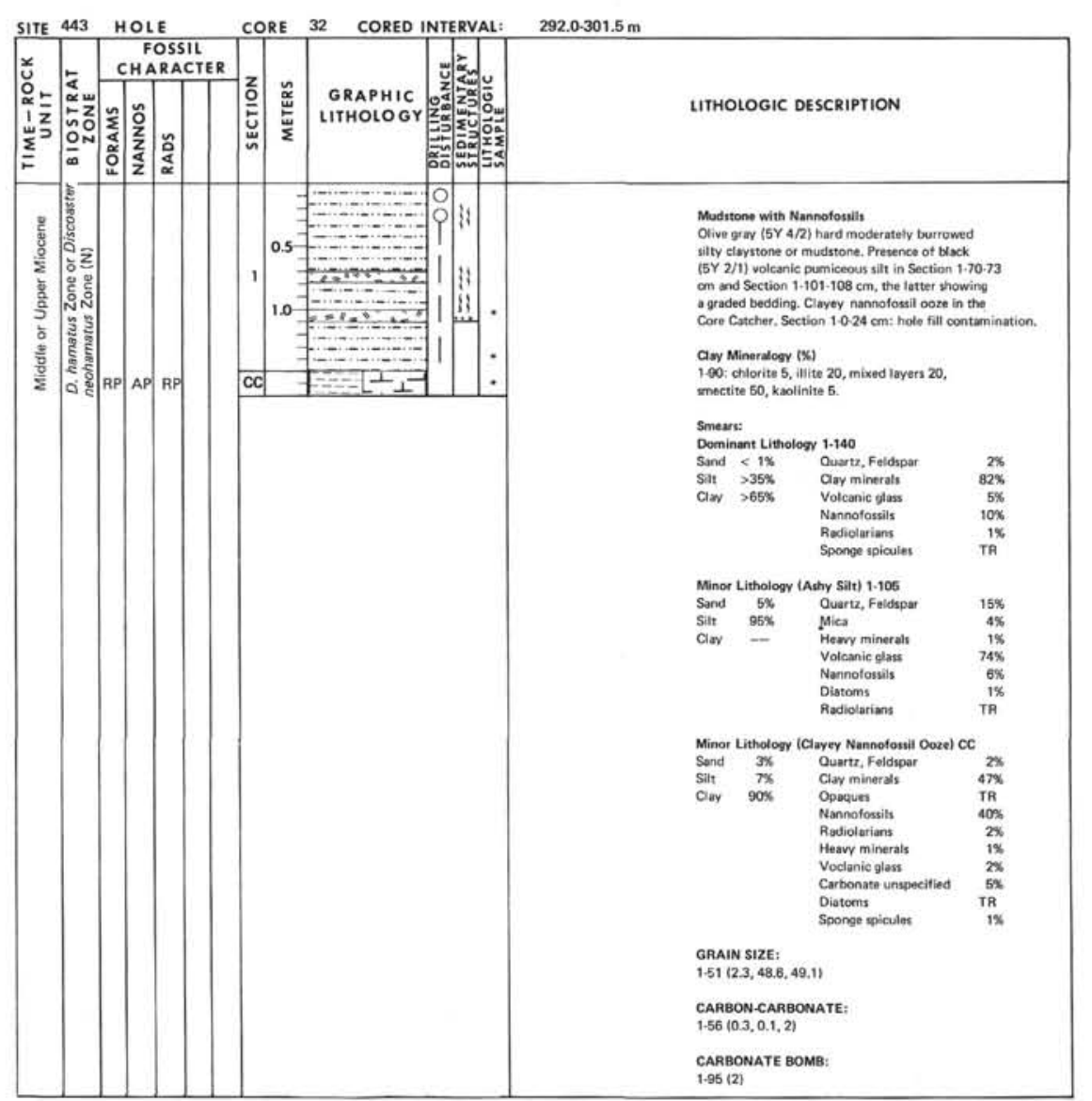

\begin{tabular}{|l|l|l|l|l|l|l|l|l|}
\hline \\
\hline
\end{tabular}
1.9562 


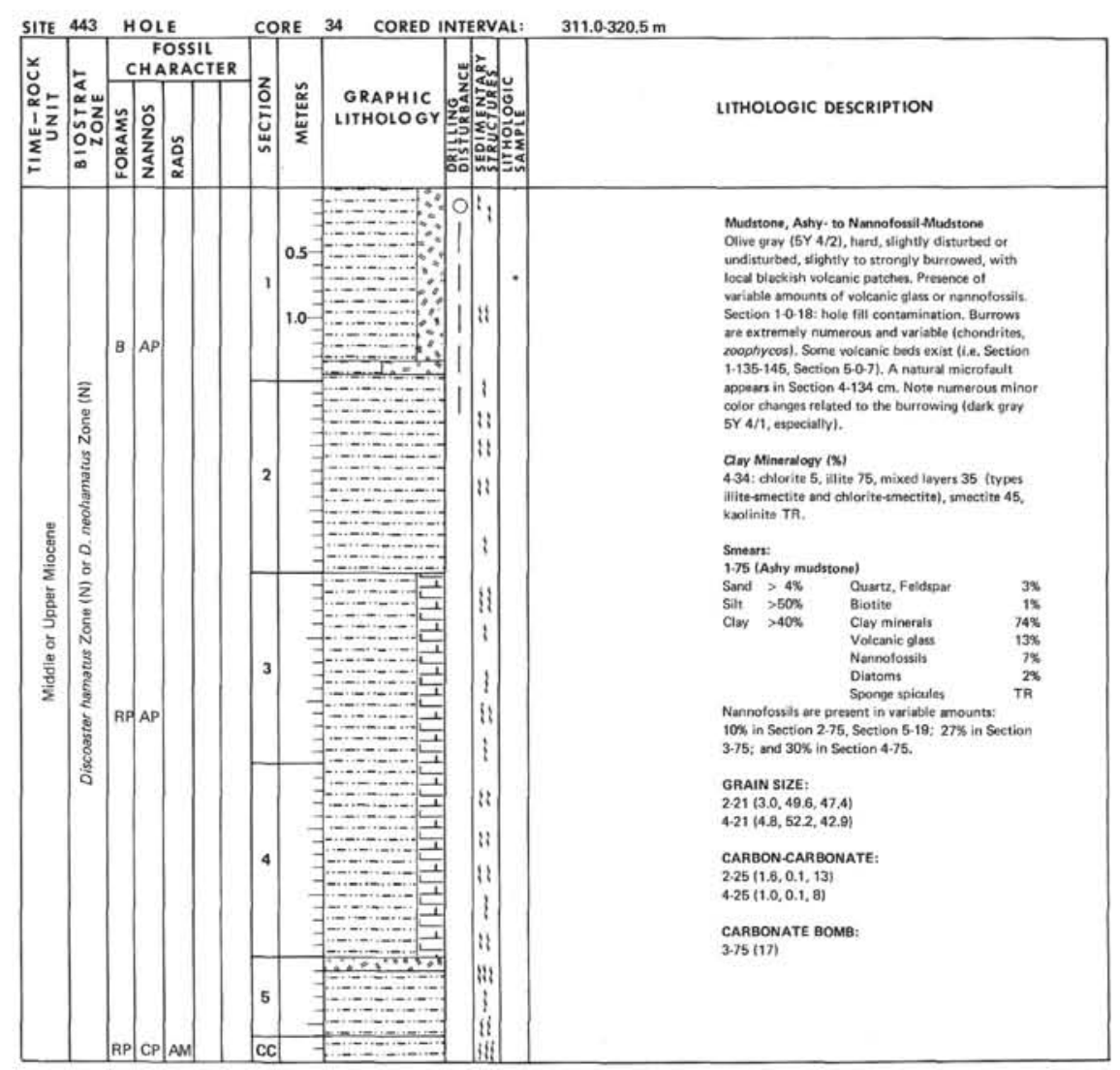

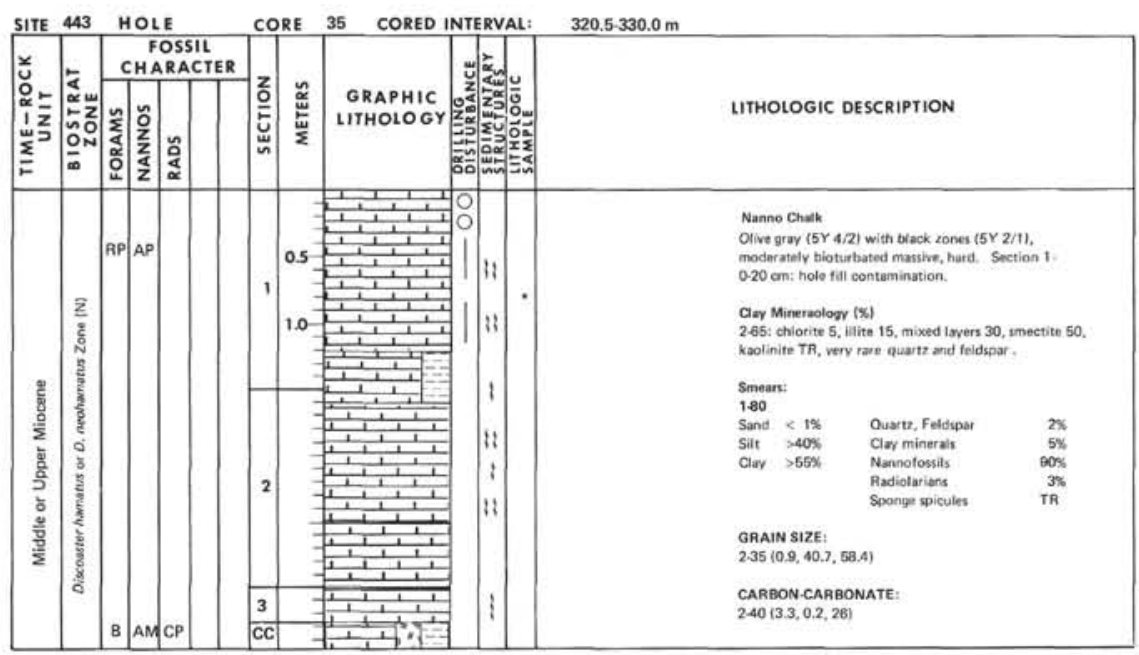




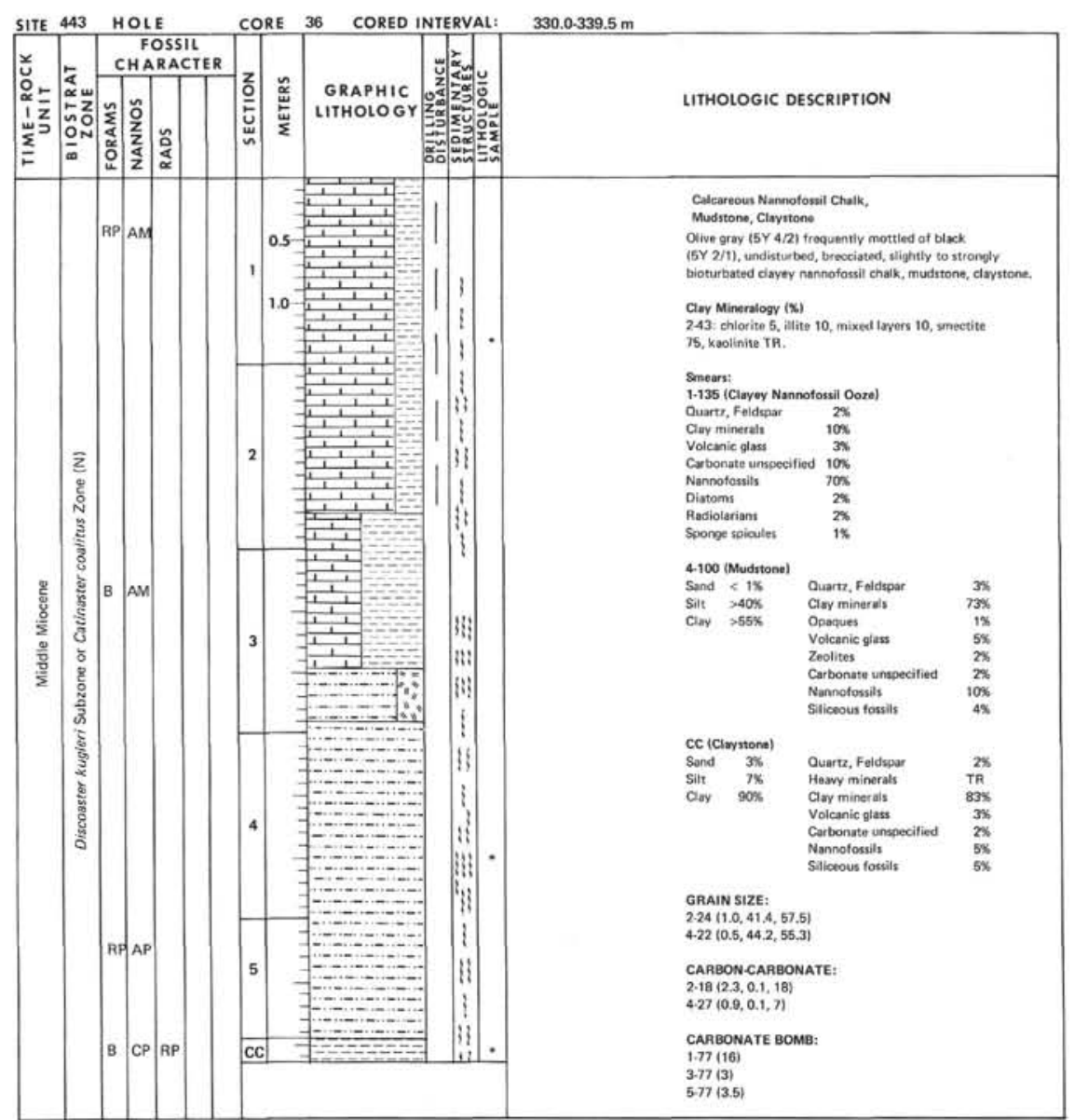

\begin{tabular}{|c|c|c|c|c|c|c|c|}
\hline \\
SITE
\end{tabular}

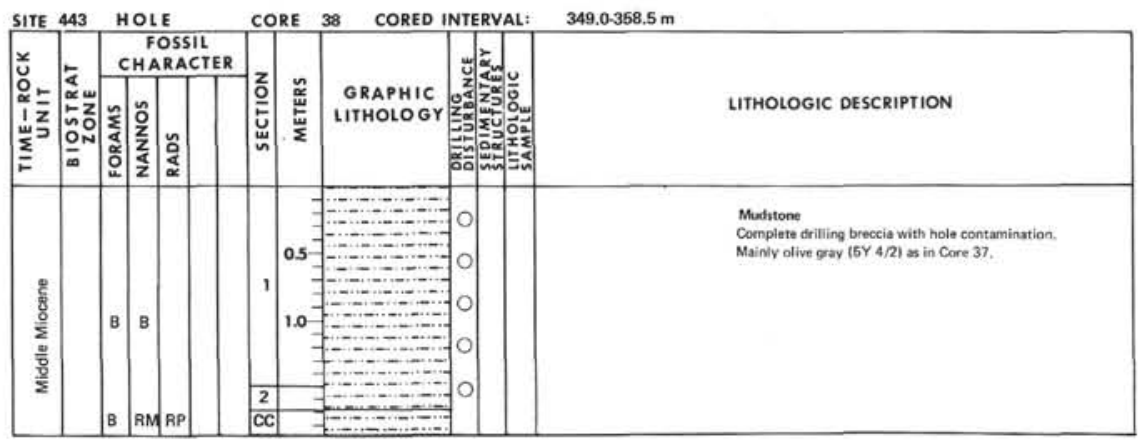




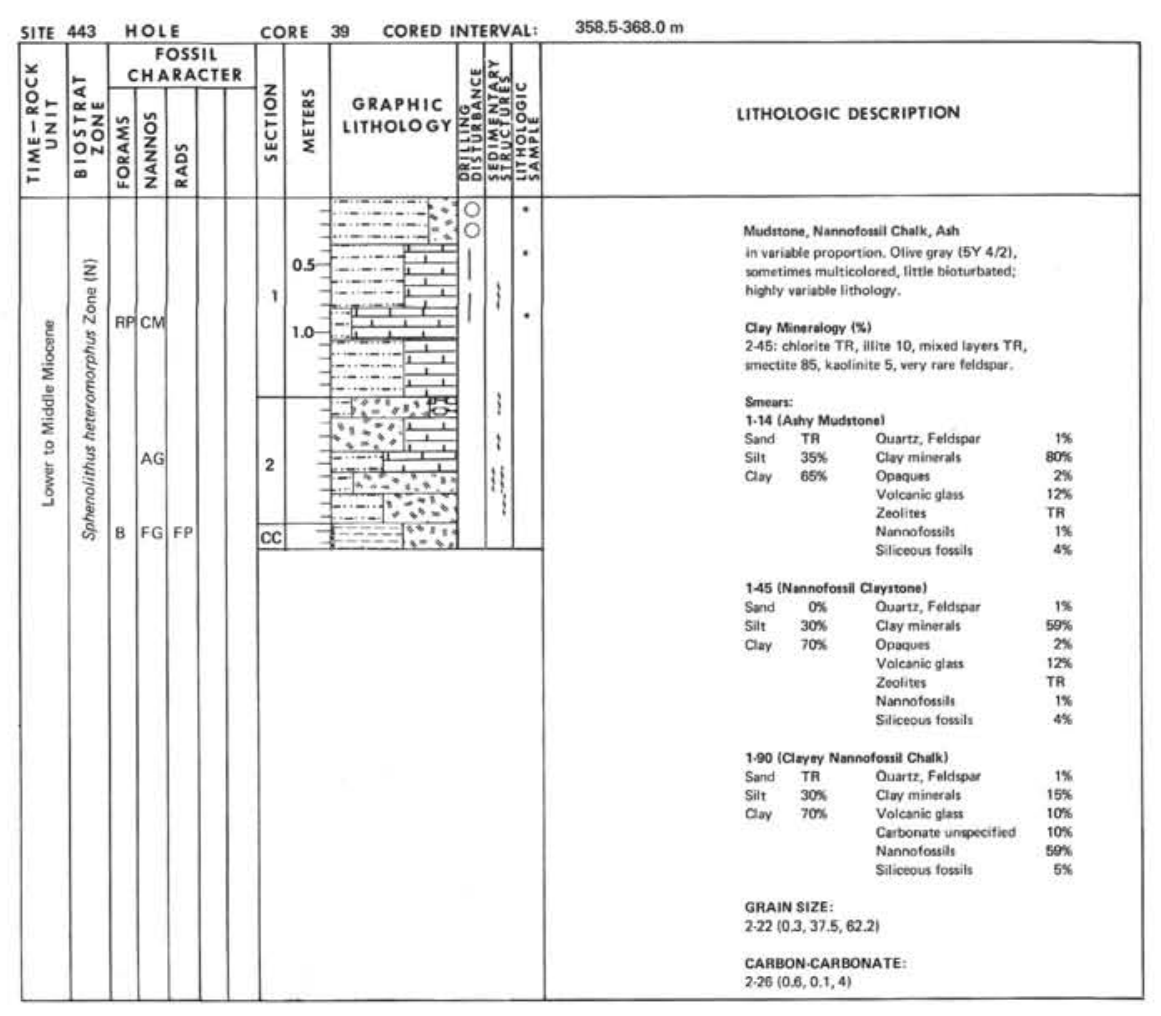

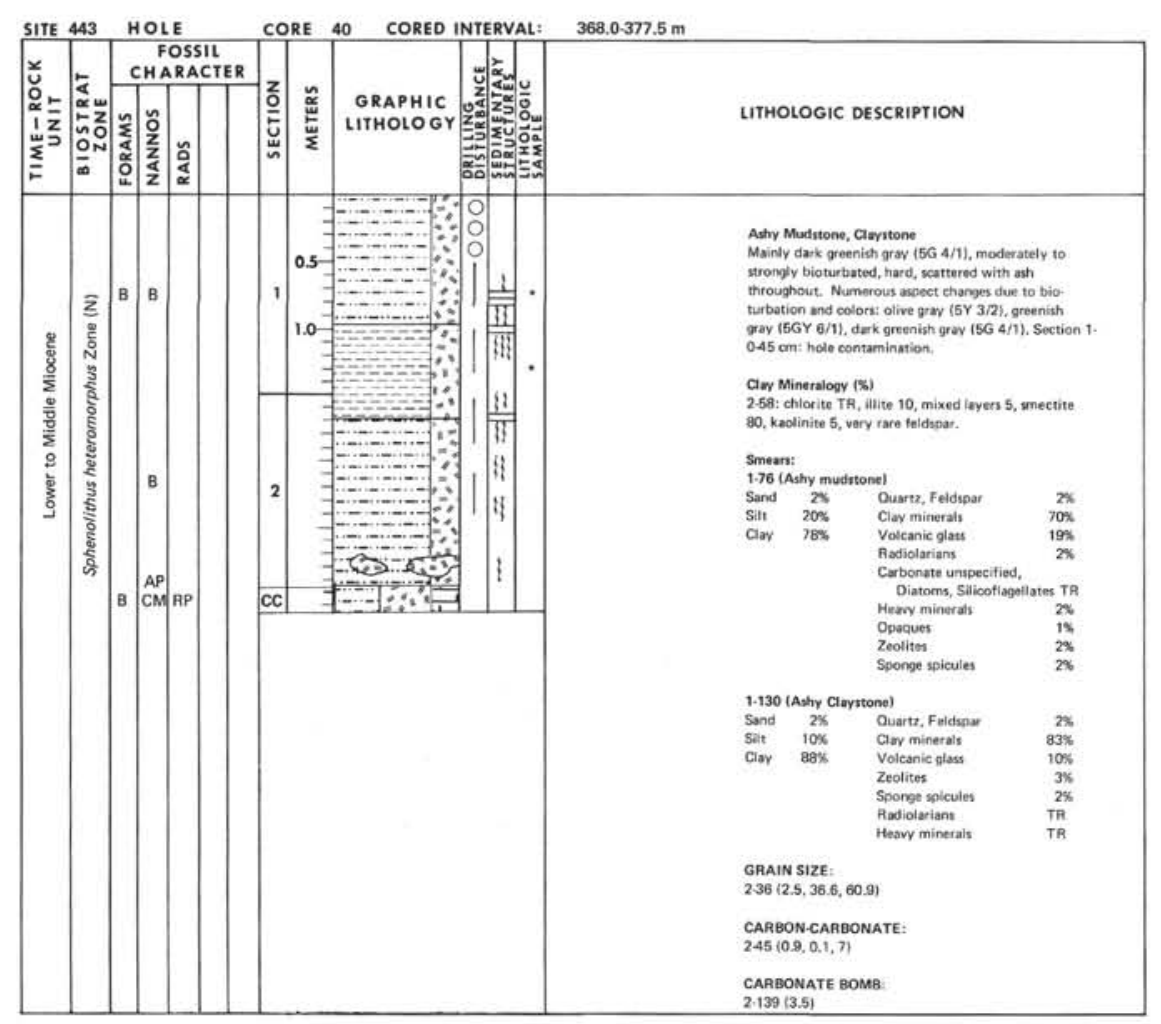



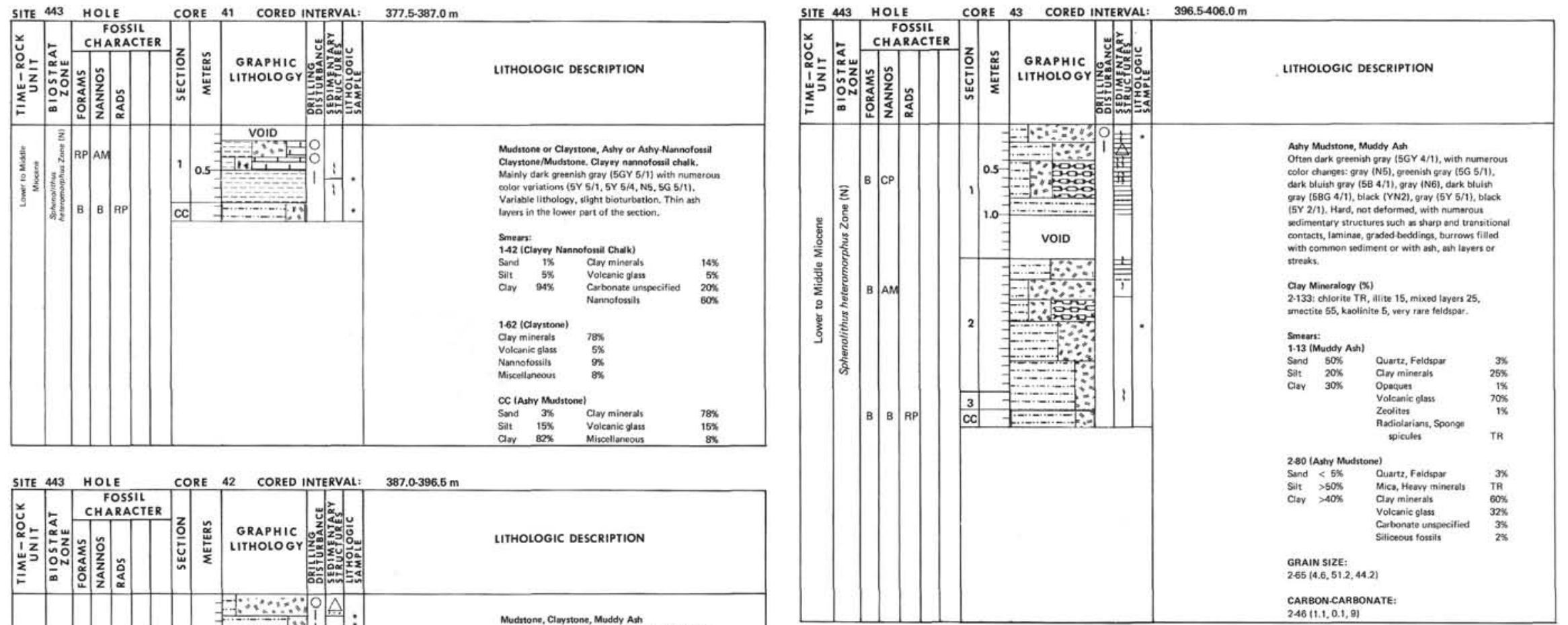

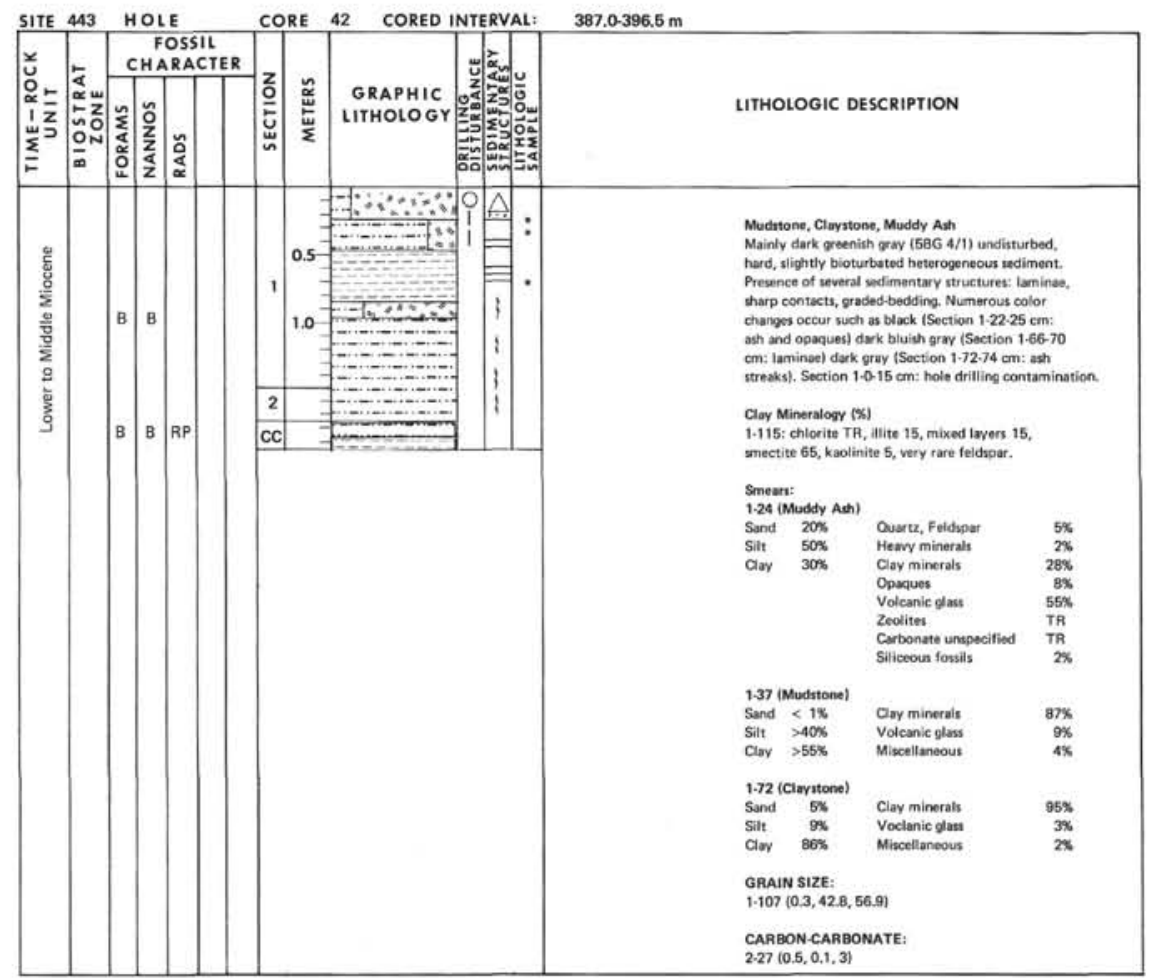

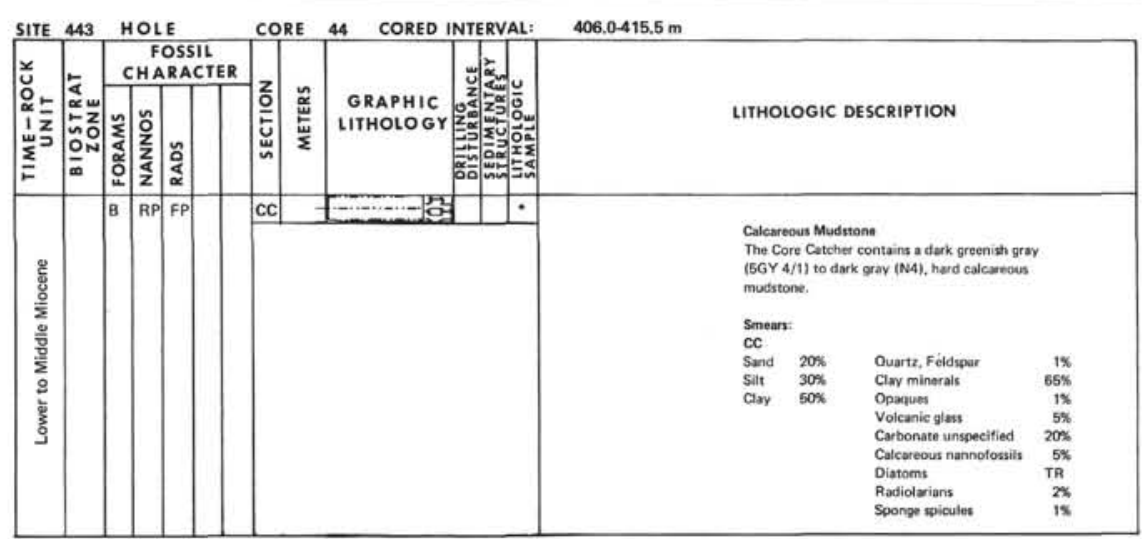



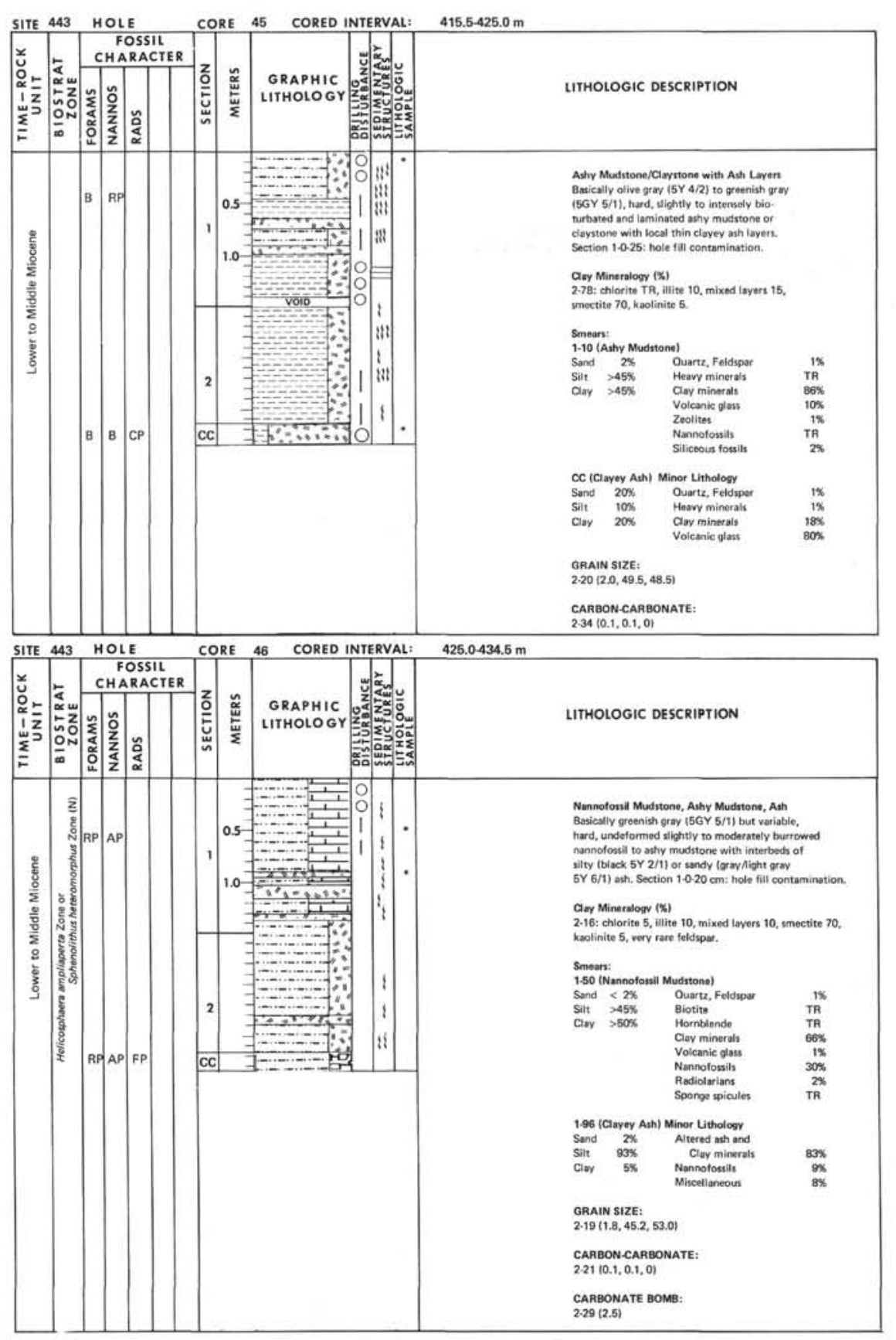

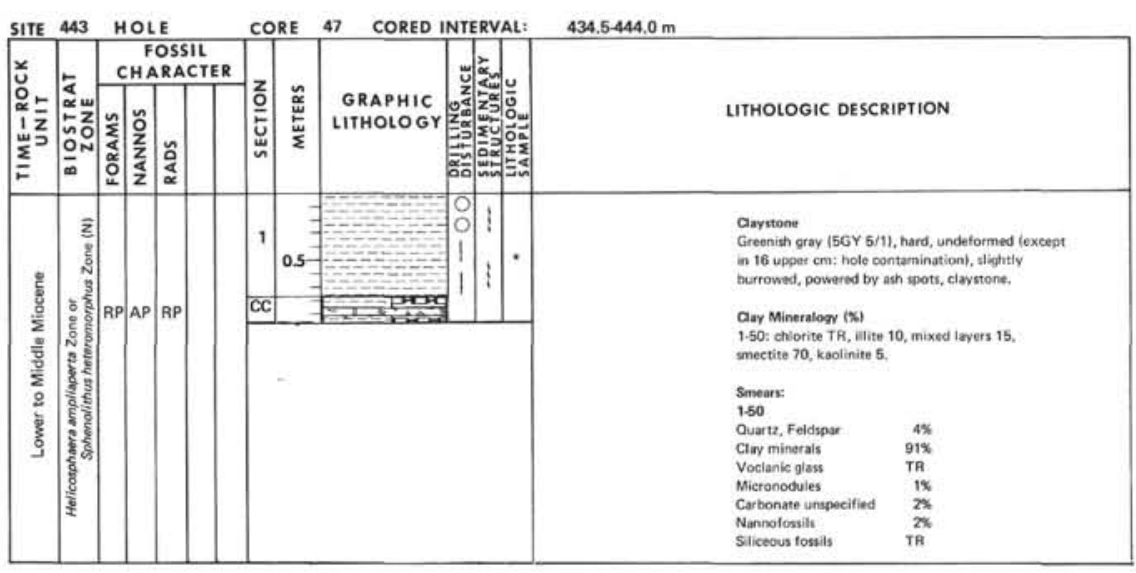

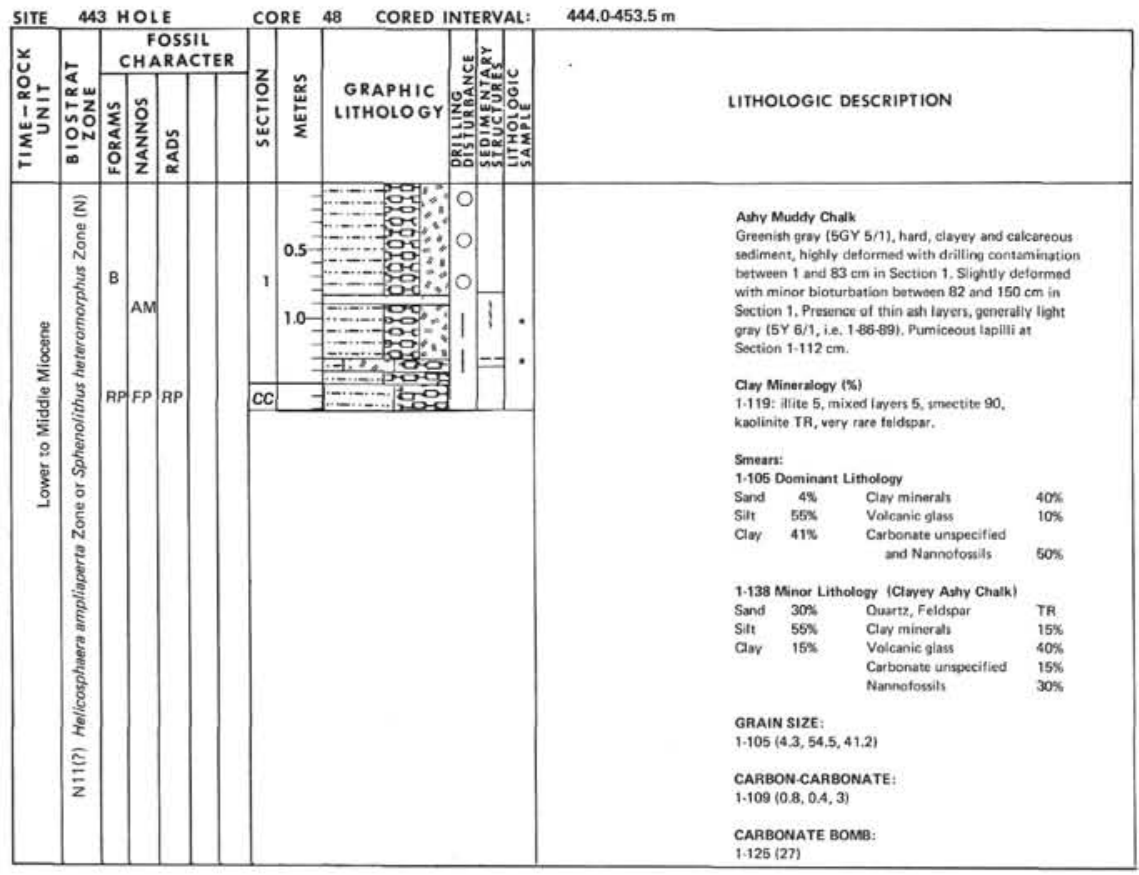



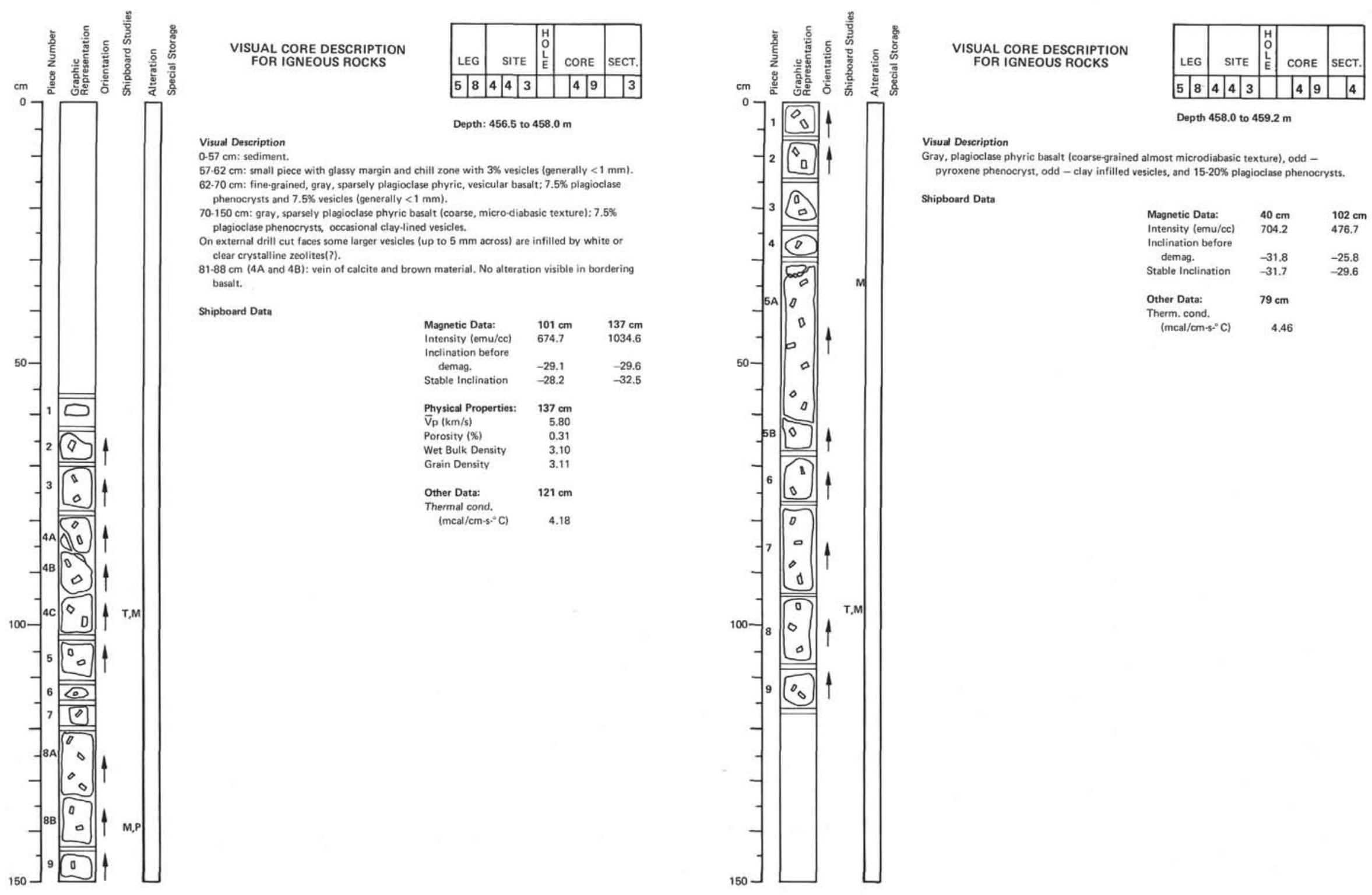


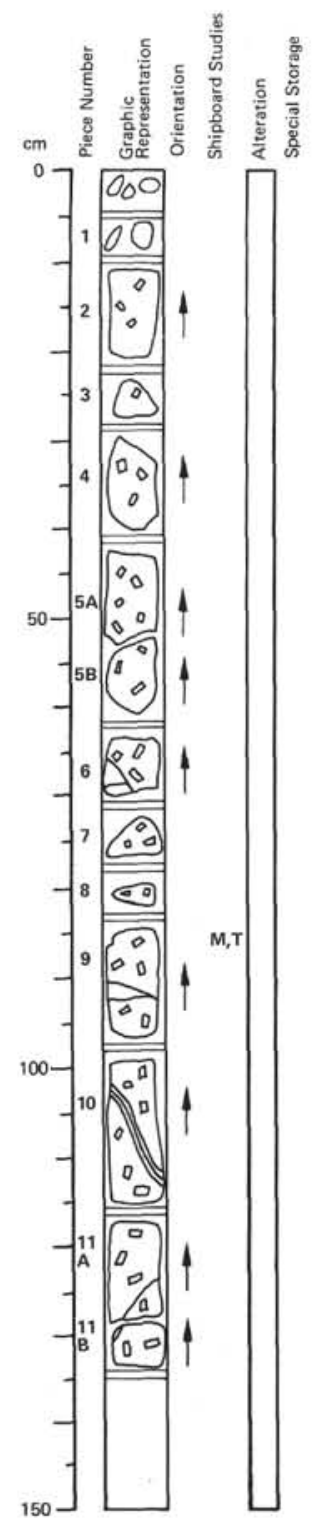

VISUAL CORE DESCRIPTION FOR IGNEOUS ROCKS

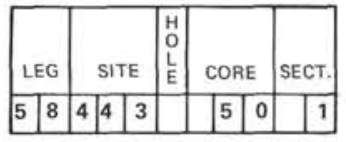

Visual Description

Depth: 463.0 to $464.3 \mathrm{~m}$

ind with 10 to $20 \%$ euhedral plagioclase from

$2107 \mathrm{~mm}$. Pyroxene phenocrysts 2 to $4 \mathrm{~mm}$ (<1\%). Amygdules filled with white

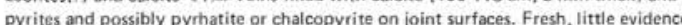

of weathering. May be chlorite on vein surfaces. Plagiociase-pyroxene phyric basalt.

vesic

Shipboard Date

Magnetic Data:

$52 \cos ^{2}$

$-28.7$

Physical Properties:

$\nabla p(\mathrm{~km} / \mathrm{s})$

Porosity (\%)

Grand

$117 \mathrm{~cm}$
5.10

2.95

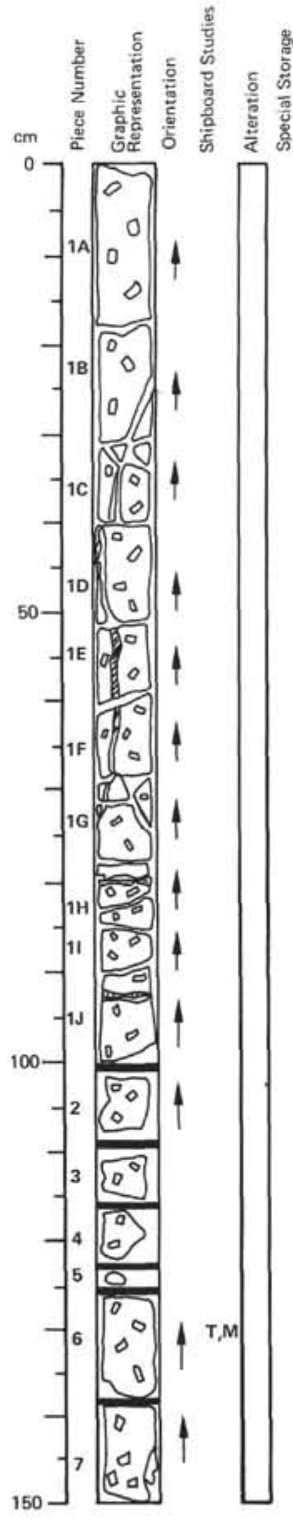

VISUAL CORE DESCRIPTION FOR IGNEOUS ROCKS

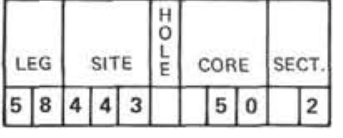

Depth: 464.3 to $465.8 \mathrm{~m}$

Visual Description

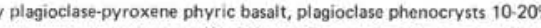
vesicles. Carbonate vein fillings abundant, free growing aragonite and pyrite (morcrsite? and green clayey mineral (glauconite?).

\section{Shipboard Data}

Ik Analysis: $\quad 14 \mathrm{~cm}$

$\begin{array}{ll}\mathrm{SiO}_{2} & 49.71 \\ \mathrm{Al}_{2} \mathrm{O}_{3} & 16.33\end{array}$

$\begin{array}{ll}\mathrm{Fe}_{2} \mathrm{O}_{3} & 1.29 \\ \mathrm{~F}_{2} & -1.35\end{array}$

$\mathrm{FeO}$

$\mathrm{MgO}$

$\mathrm{CaO}$

$\mathrm{Na}_{2} \mathrm{O}$
$\mathrm{K}_{2} \mathrm{O}$
$\mathrm{O}_{2} \mathrm{O}_{2}$

$\mathrm{K}_{2} \mathrm{O}$

${ }_{\mathrm{MnO}}$

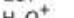

$\mathrm{H}_{2} \mathrm{O}^{-} \quad-$

$\mathrm{Cr}^{2} \quad \overline{198.00}$

$\begin{array}{lr}\mathrm{Ni} & 50.00 \\ \mathrm{Si} & 151.00 \\ \mathrm{Zr} & \end{array}$

$\begin{array}{ll} & 151.00 \\ \mathrm{Zr} & 121.00\end{array}$
Magnetic Data: $\quad 30 \mathrm{~cm}$ Inclination before

$\begin{array}{ll}\text { demag. } & -31.3 \\ \text { Stable Inclination } & -29.9\end{array}$

Other Data: $\quad 0 \mathrm{~cm}$

4.35 

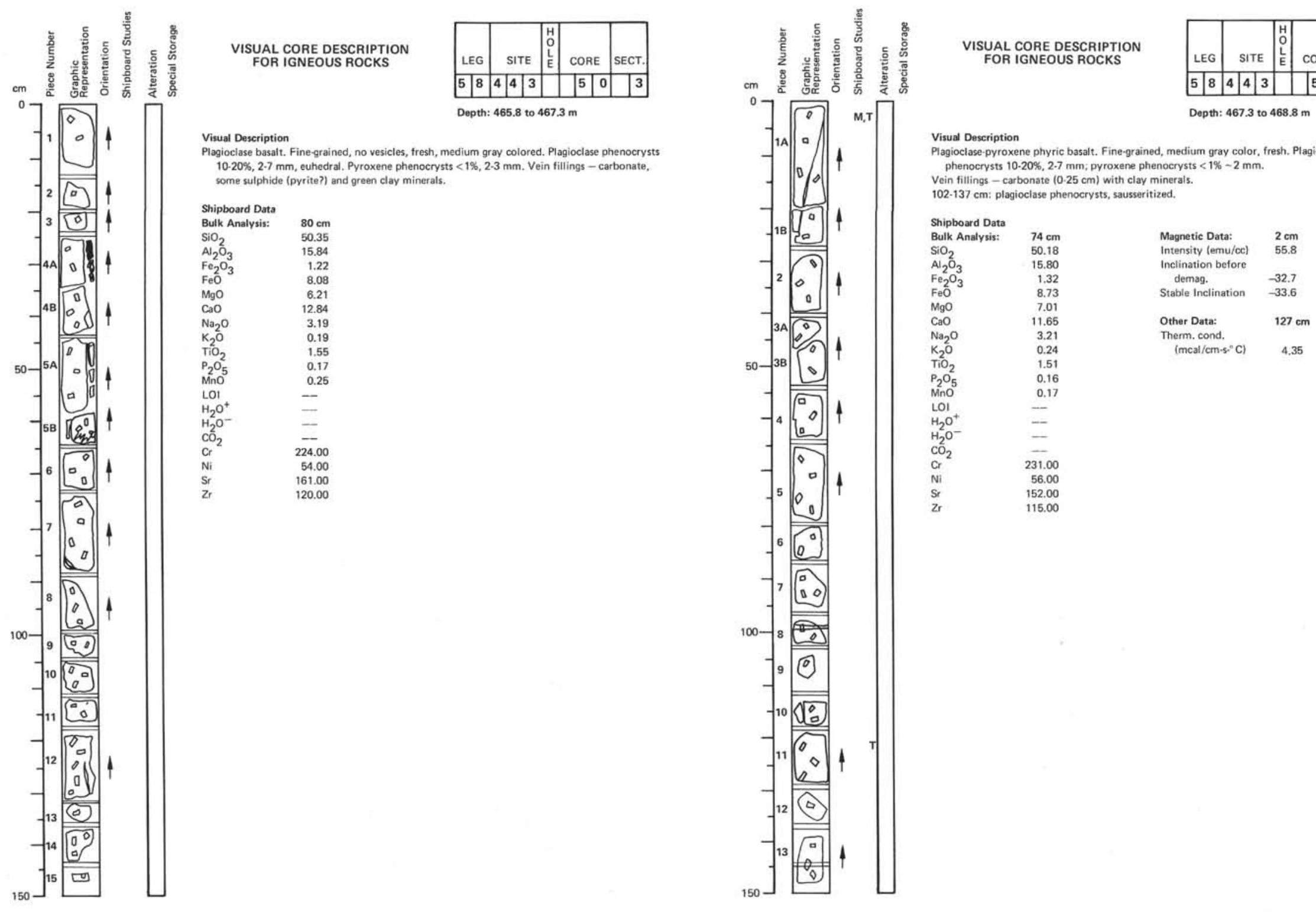

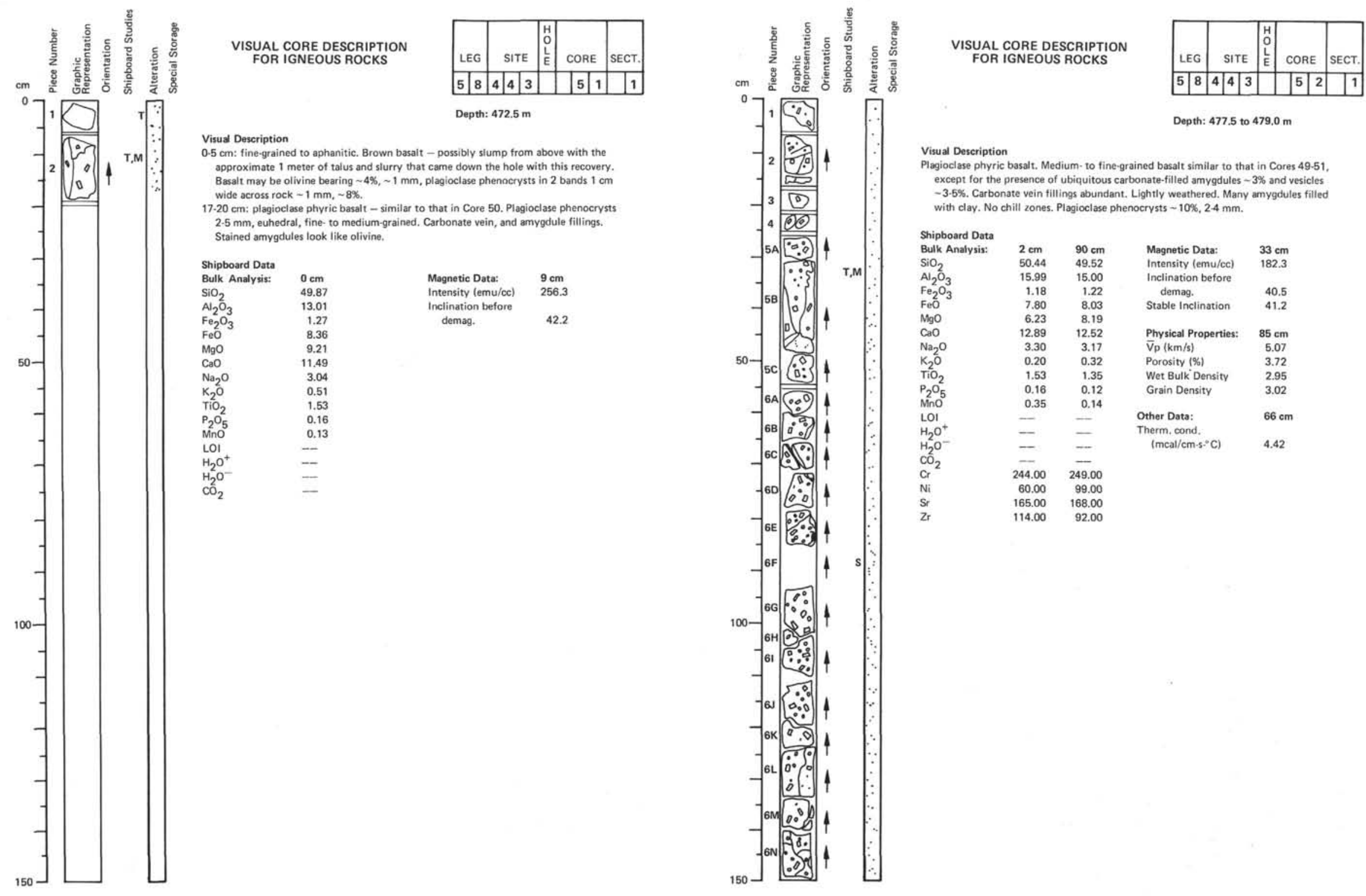

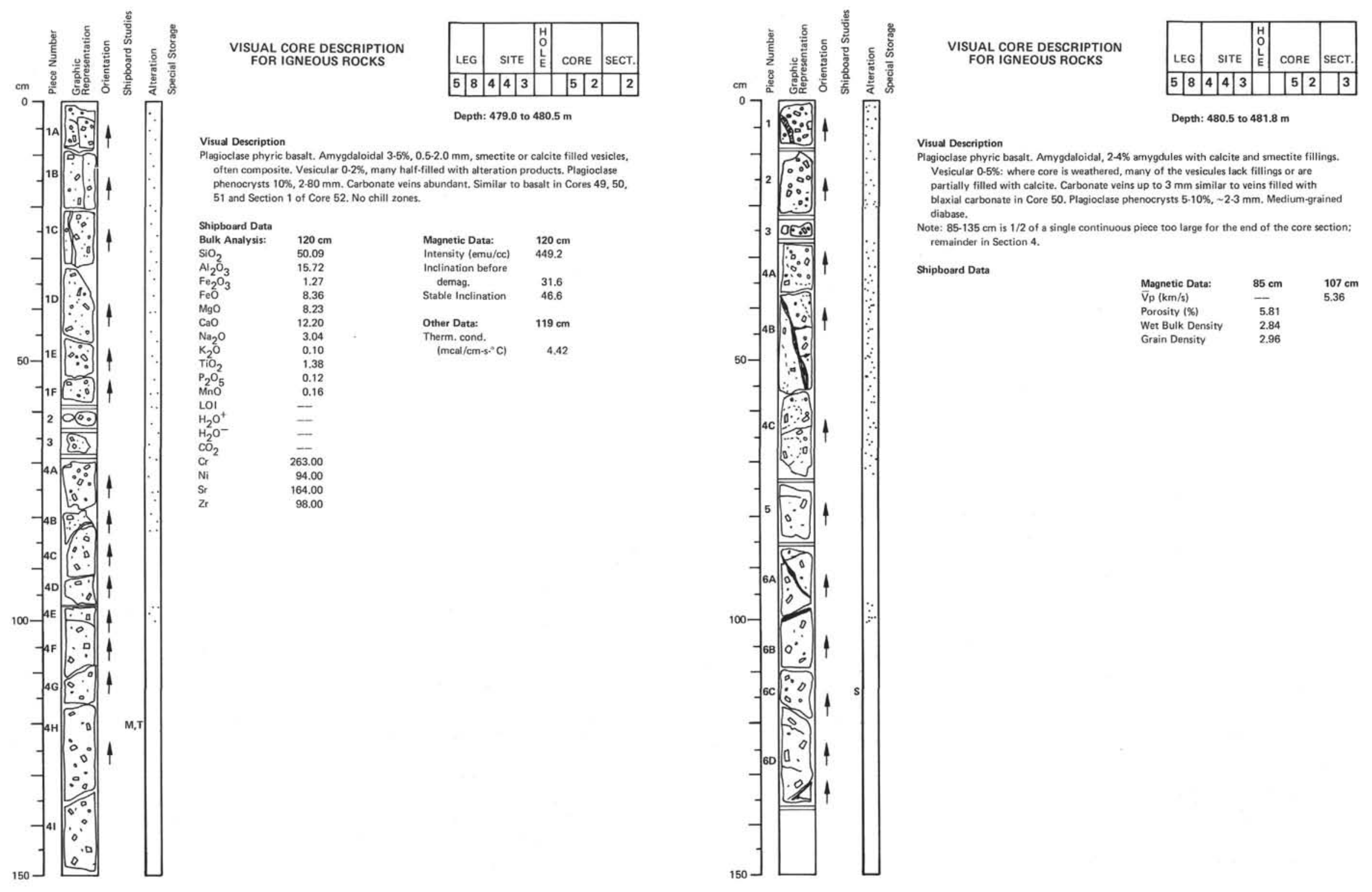

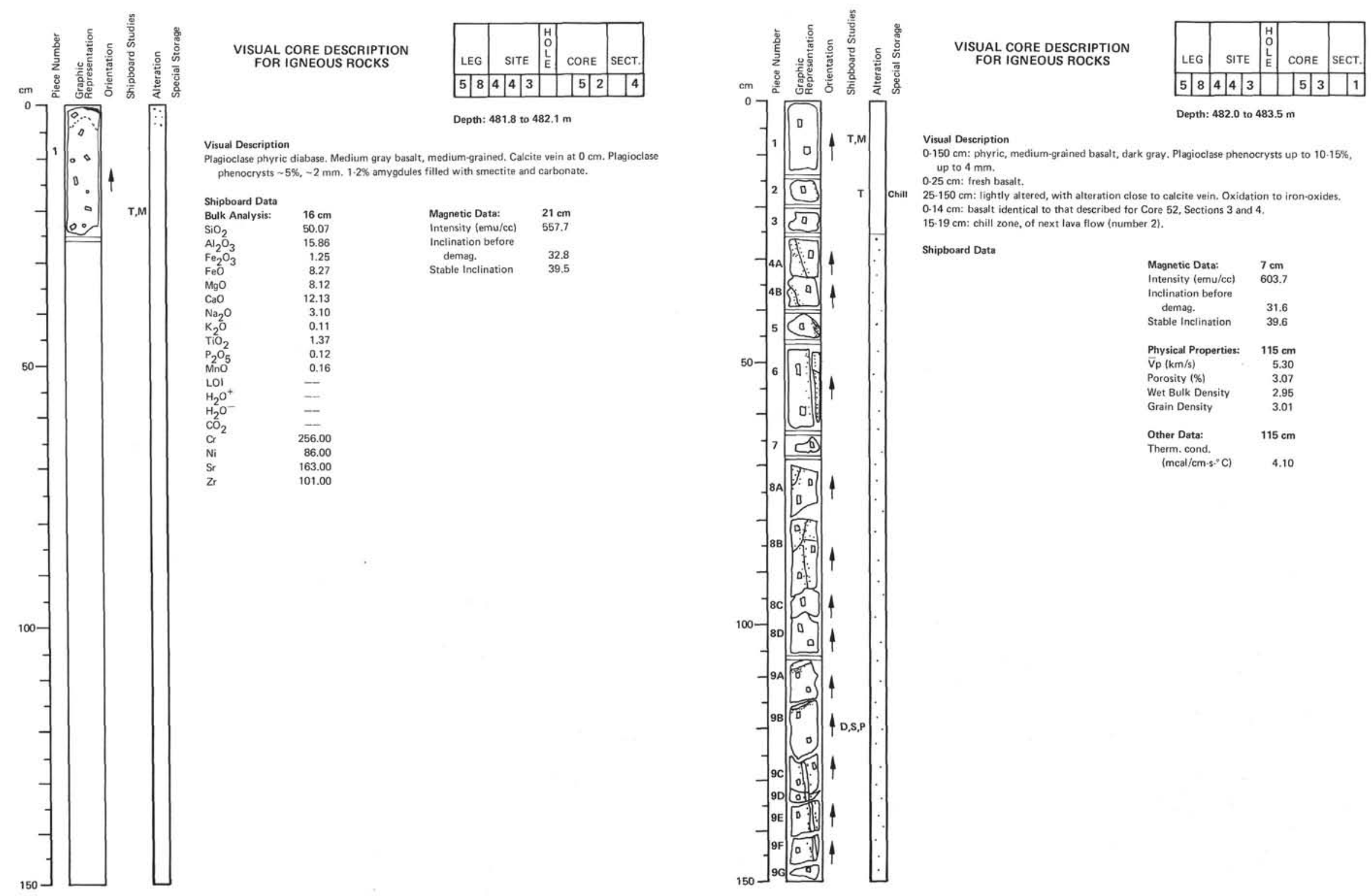

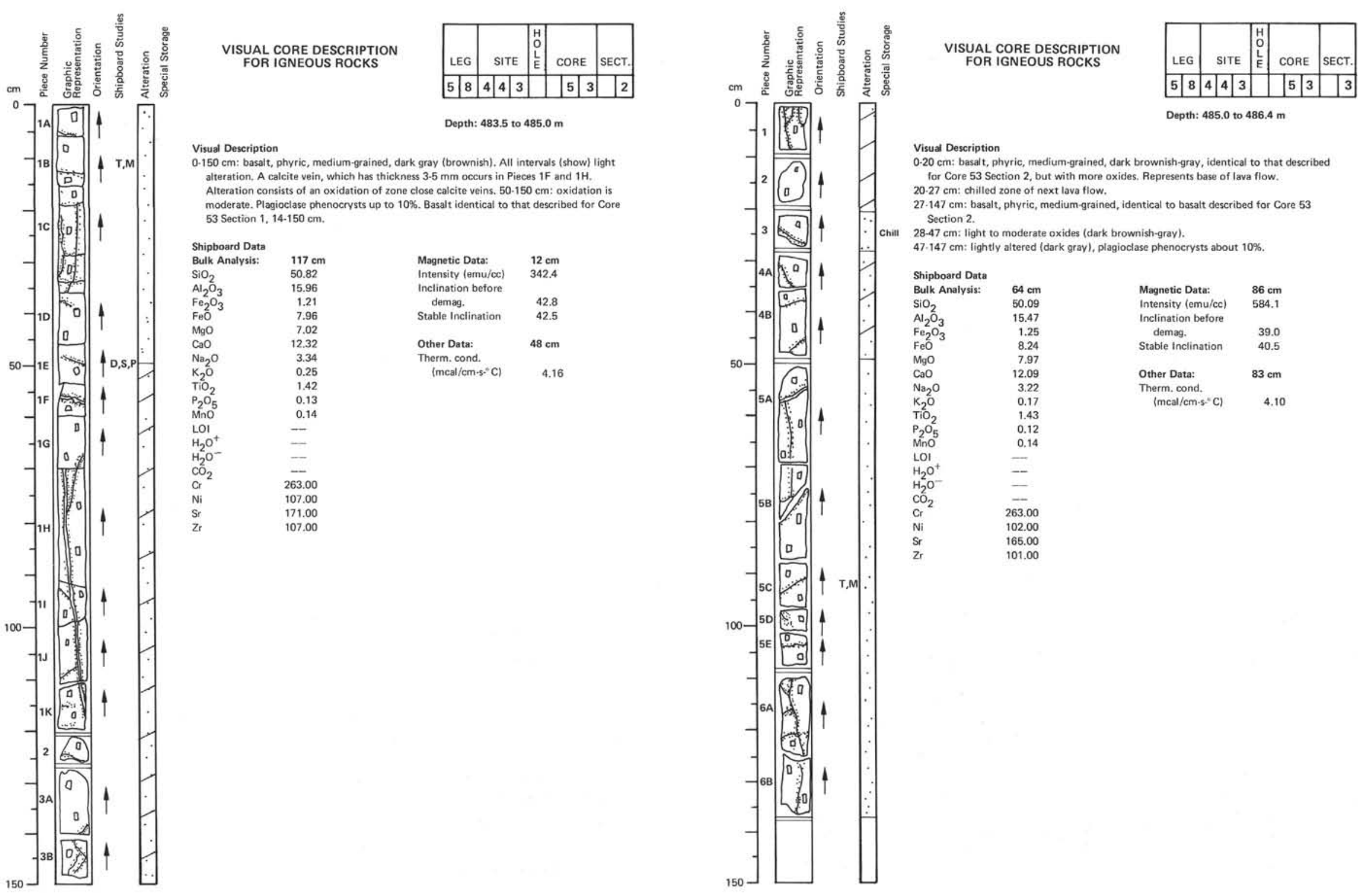

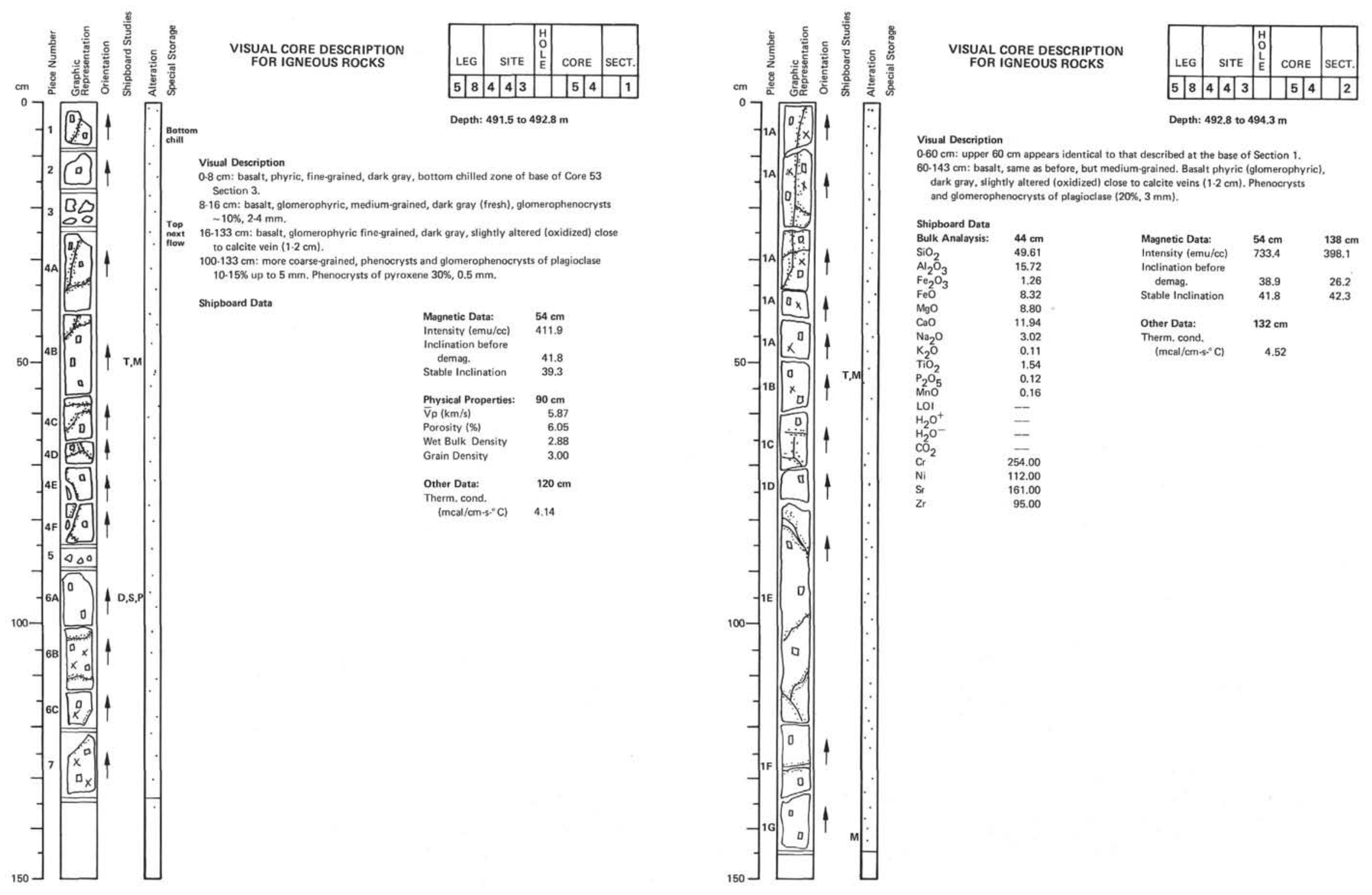

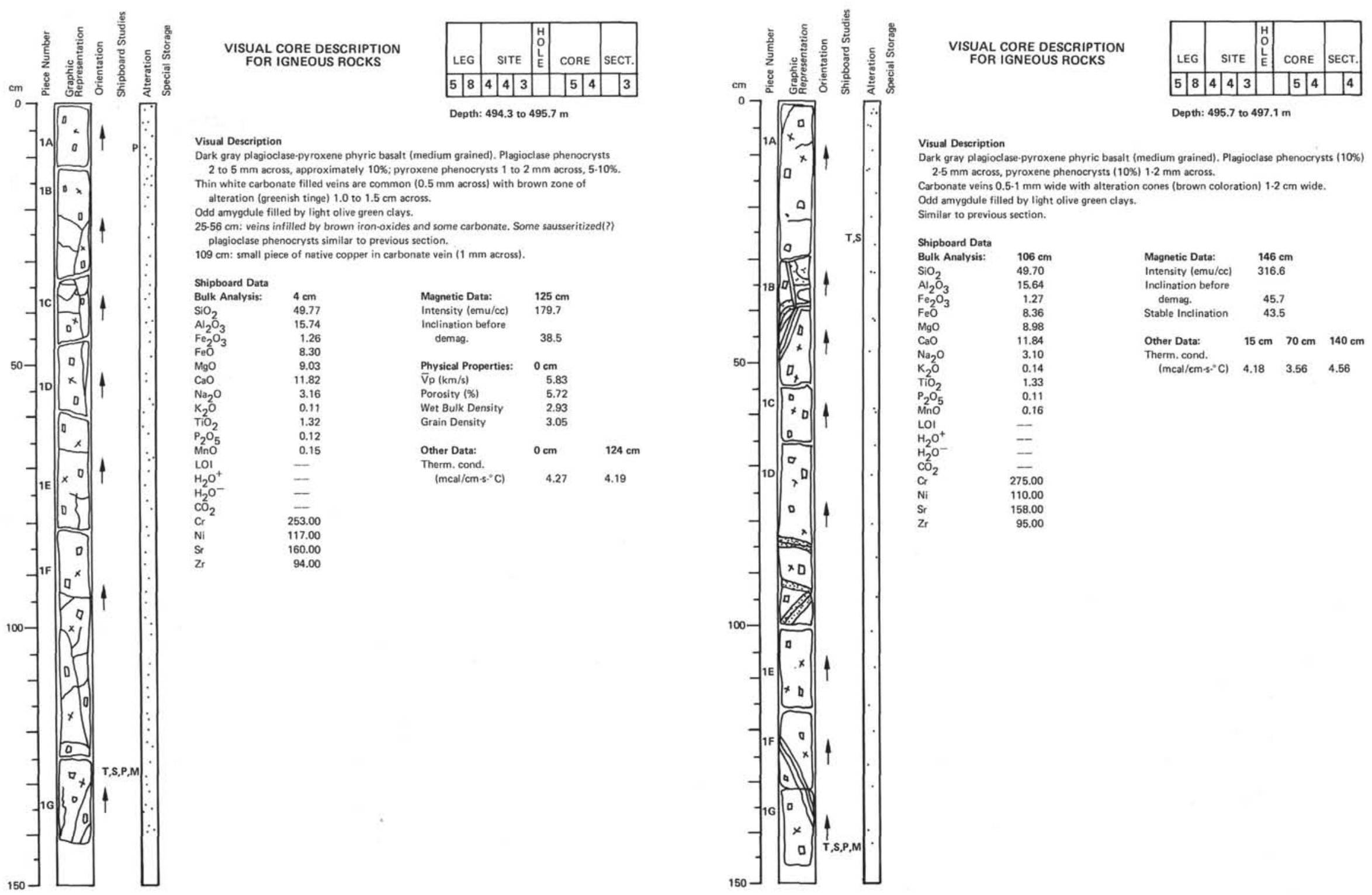

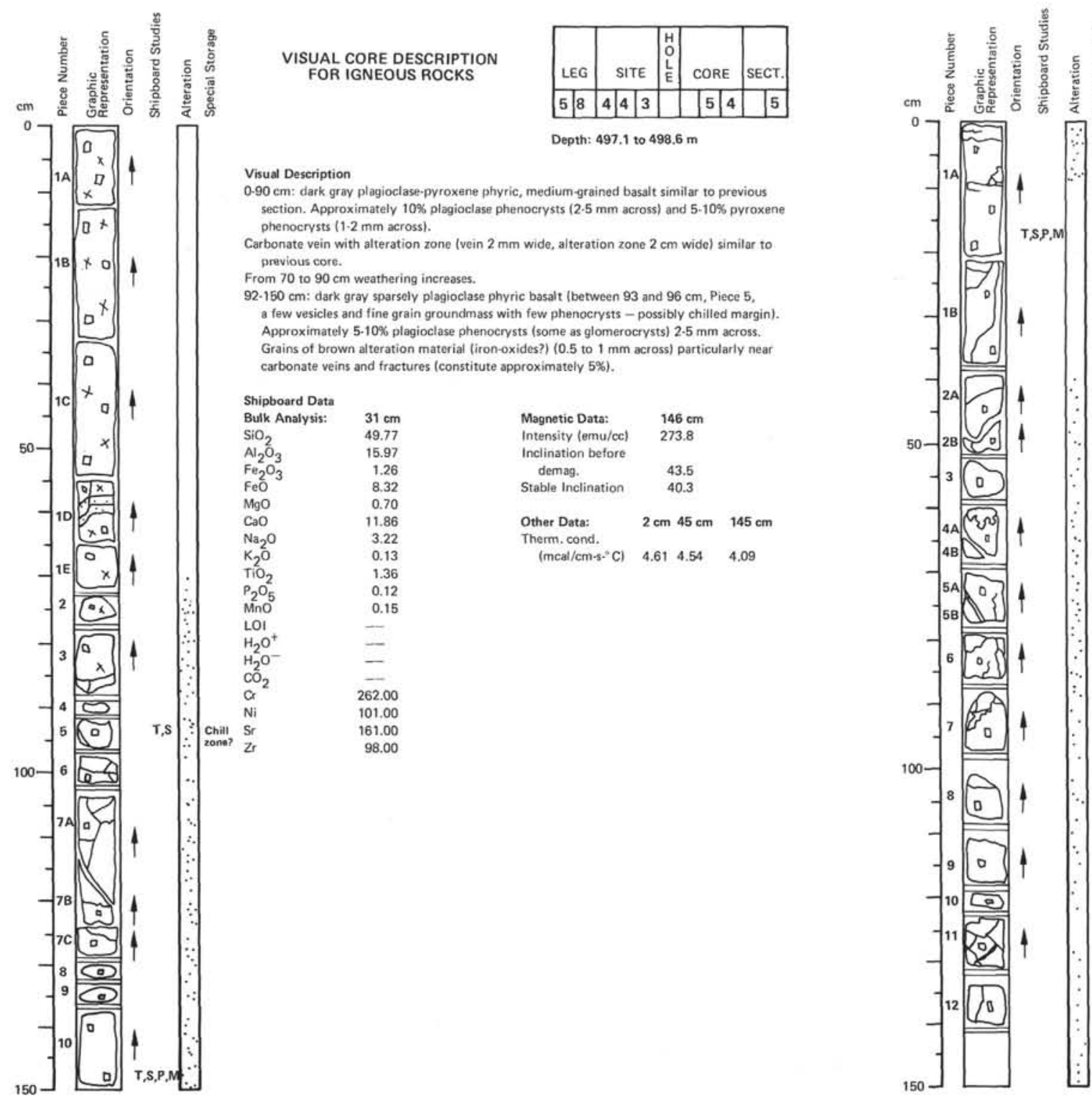
VISUAL CORE DESCRIPTION FOR IGNEOUS ROCKS

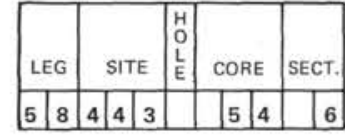 Depth: 498.6 to $500.0 \mathrm{~m}$

Visual Description

Dark gray, sparsely plagioclase phyric basalt. Approximately 5-10\% phenocrysts isome as Odd grains of brown alteratos. with similar material. Also occasional round vesicle infilled by a dark gray material (clay?).

$\begin{array}{lrlr}\text { Shipboard Data } & & & \\ \text { Bulk Analysis } & 36 \mathrm{~cm} & \text { Magnetic Data: } & 14 \mathrm{~cm} \\ \mathrm{SiO}_{2} & 49.84 & \text { Intensity (emu/cc) } & 1328.3 \\ \mathrm{Al}_{2} \mathrm{O}_{3} & 15.73 & \text { Inclination before } & \\ \mathrm{Fe}_{2} \mathrm{O}_{3} & 1.24 & \text { demag. } & 41.9 \\ \mathrm{FeO} & 8.21 & \text { Stable Inclination } & 46.1 \\ \mathrm{MgO} & 8.26 & \text { Other Data: } & 28 \mathrm{~cm} \\ \mathrm{CaO} & 12.16 & \text { Therm. cond. } & \\ \mathrm{Na}_{2} \mathrm{O} & 3.06 & \text { (mcal/cm-5. C) } & 4.14 \\ \mathrm{~K}_{2} \mathrm{O} & 0.12 & & \end{array}$




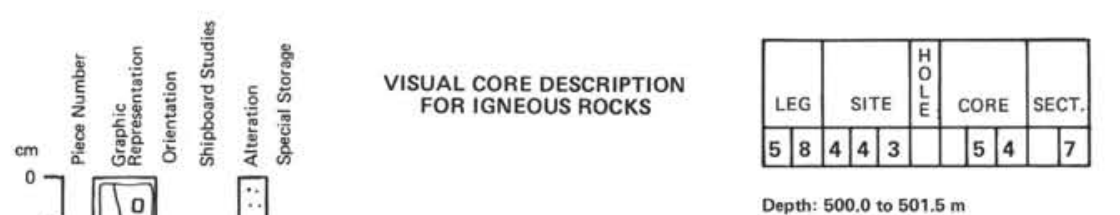

Visual Description

Depth: 500.0 to $501.5 \mathrm{~m}$

. tractures. Odd pyroxene phenocrysts, similar to previous section.

$10-150 \mathrm{~cm}$ : vesicular, gray basalt, aphyric 5-20\% vesicles, many from $0.5-2 \mathrm{~mm}$ across and some large composite ones. Weathering in zones around vesicles particularly in Piece 6

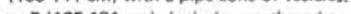

carbonate band (lithified sediment?), Lithified cones (chill margins?) above and below $150 \mathrm{~cm})$.

Above Piece $5(125 \mathrm{~cm})$ : vesicles lined by dark material and clear well formed cr
(zoolite?).
Below Piece 5 ( $131 \mathrm{~cm})$ : vesicles filled or lined by light brownish gray clay(?).

Bulk Analysis: $\quad 71 \mathrm{~cm}$

$\begin{array}{ll}\mathrm{SiO}_{2} & 49.90 \\ \mathrm{Al}_{2} \mathrm{O}_{3} & 15.73\end{array}$

$\mathrm{Fe}_{2} \mathrm{O}_{3} \quad 1.26$

8.28

$\mathrm{MgO}$

$\mathrm{Na}_{2} \mathrm{O} \quad 3.10$

0.09
$\mathrm{TiO}_{2}$

$\begin{array}{ll}\mathrm{P}_{2} \mathrm{O}_{5} & 0.11 \\ \mathrm{MnO} & 0.15\end{array}$

$\mathrm{H}_{2} \mathrm{O}^{+}$

$\mathrm{CO}_{2} \quad-$

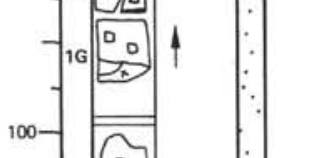

$\mathrm{Sr}$

$-2 \times 0$

$-101$

$-1400$

$-5$

160

$-1 \frac{6}{\circ}$

\begin{tabular}{lrr} 
Magnetic Data: & $76 \mathrm{~cm}$ & \multicolumn{1}{c}{$138 \mathrm{~cm}$} \\
Intensity (emu/cc) & 611.7 & 731.7 \\
Inclination before & & \\
demag. & 37.4 & 63.5 \\
Stable Inclination & 41.5 & 62.8 \\
Physical Properties: & $60 \mathrm{~cm}$ & $67 \mathrm{~cm}$ \\
Vo (km/s) & 5.91 & - \\
Porosity (s) & 7.98 & 3.53 \\
Wet Bulk Density & 2.97 & 2.93 \\
Grain Density & 3.14 & 3.00 \\
Other Data: & $60 \mathrm{~cm}$ & \\
\hline
\end{tabular}

(mcal/cm.5. $\left.{ }^{\circ} \mathrm{C}\right) \quad 4.53$

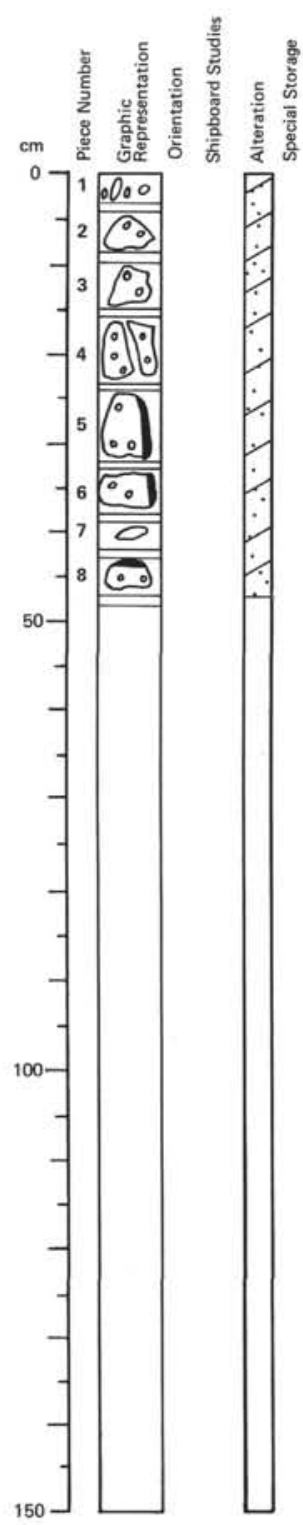

VISUAL CORE DESCRIPTION FOR IGNEOUS ROCKS

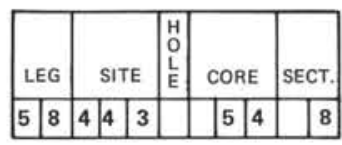

Depth: 5015 to $5020 \mathrm{~m}$

Visual Description

sightly vesicular, gray, aphyric tine-grained basals. Glassy rinds (and chill margins) on Pieces: $5,25.31 \mathrm{~cm}, 6,32.36 \mathrm{~cm}$, and $8,43.46 \mathrm{~cm}$.

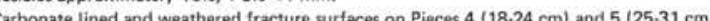
Weathering gives greenish tinge to clay and carbon Some alteration of glassy rinds to palagonite. 

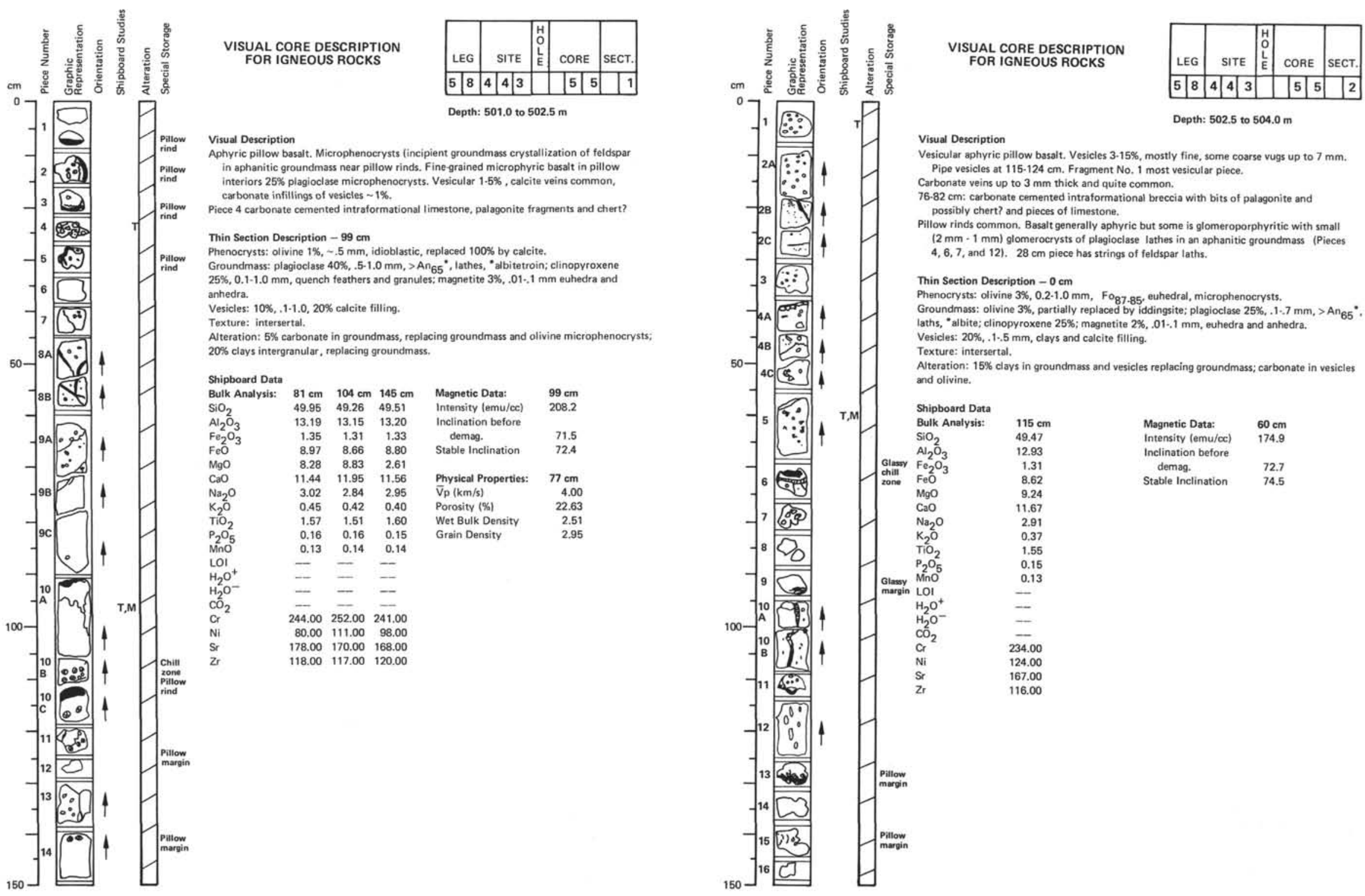

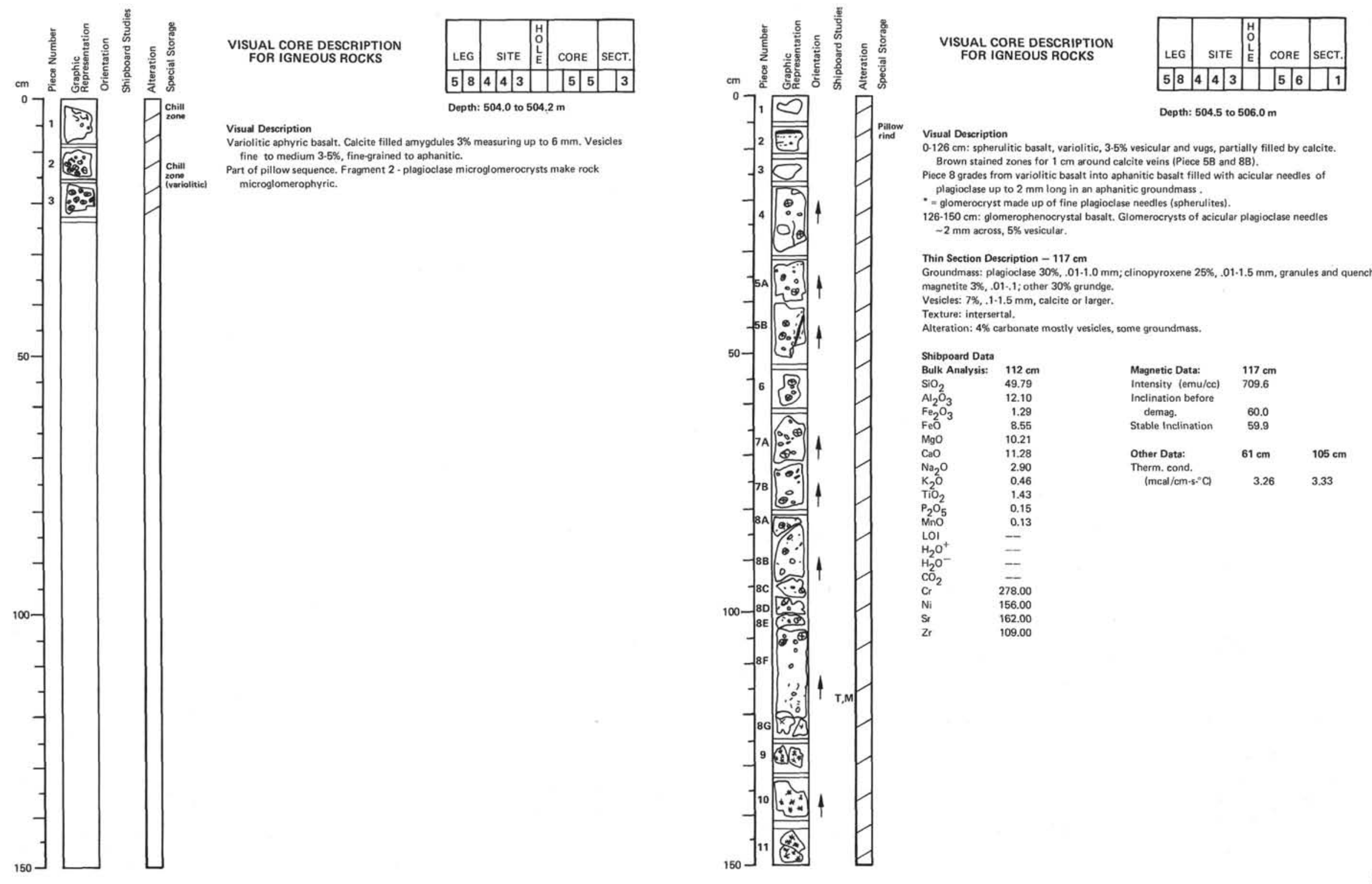


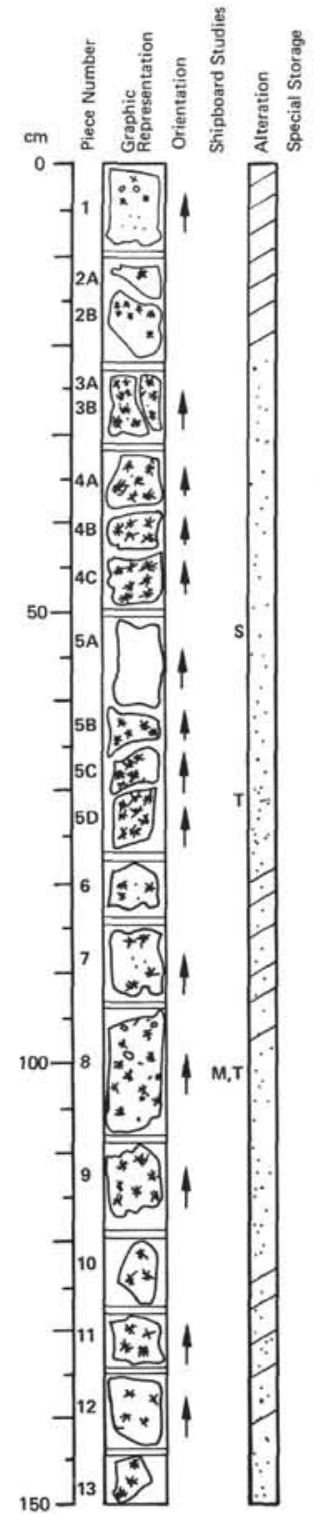
VISUAL CORE DESCRIPTION
FOR IGNEOUS ROCKS

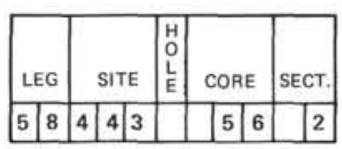

Visual Description

reaks in section (not chill zones) at 23 and $77 \mathrm{~cm}$.

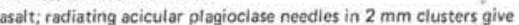

rock a spotted appearance, groundmass aphanitic $2 \cdot 10 \%$ vesicules, a few vugs.

$77.150 \mathrm{~cm}$; rock grades from a few spherulites $\sim 5 \%$ to $-30 \%$ spherulites at base.

Thin Section Description $-60 \mathrm{~cm}$

ral, replaced $100 \%$ by calcite.

soundmass microlites; other grundge remainder.

Texture: intersertal.

Alteration: $4 \%$ carbonate replacing olivine microphenos.

Thin Section Description $-68 \mathrm{~cm}$

${ }^{2}>\mathrm{An}_{73}{ }^{\circ}$, acicular needles and laths, "albite hour .

Vesicles: $25 \%, 2-2.0 \mathrm{~mm}$, irregular to round.

Aiteration: $3 \%$ carbonate, some vugs and some groundmass.

Shipboard Data

$\mathrm{SiO}_{2}$

$103 \mathrm{~cm}$
48.89
13.75
1.21

1.21
7.98

$\mathrm{MeO}$

$\mathrm{CaO}$

$\quad 14.02$

$\mathrm{K}_{2} \mathrm{O} \quad 0.28$

$\begin{array}{ll}\mathrm{K}_{2} \mathrm{O}_{2} & 0.56 \\ \mathrm{P}_{2} \mathrm{O}_{5} & 0.16 \\ \mathrm{MnO} & 0.13\end{array}$

LOI

$\mathrm{H}_{2} \mathrm{O}^{+}=$

$\mathrm{CO}_{2} \quad-\overline{-}$

$\mathrm{Ni}-8.00$

$\begin{array}{ll}\mathrm{Sr} & 176.00 \\ \mathrm{Zr} & 122.00\end{array}$

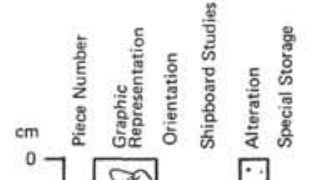

VISUAL CORE DESCRIPTION

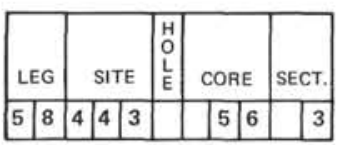

Depth: 507.5 to $508.9 \mathrm{~m}$

Plagioclase spherulitic basalt grading into plagioclase microphyric basalt in a single unit which started in the preceding section $(S \operatorname{Section} 2,77 \mathrm{~cm})$. Acicular plagioclase spherulites at top groundmass

Calcite veins have iron-oxide stain for a 1 to $11 / 2 \mathrm{~cm}$ zone around them. Calcite amygdules $125.142 \mathrm{~cm}$

\begin{tabular}{|c|c|c|c|c|}
\hline Bulk Analysis & $113 \mathrm{~cm}$ & Magnetic Data: & $120 \mathrm{~cm} \mathrm{c}$ & \\
\hline $\mathrm{SiO}_{2}$ & 50.18 & Intensity (emu/cc) & 53.3 & \\
\hline $\mathrm{Al}_{2} \mathrm{O}_{3}$ & 13.89 & Inclination before & & \\
\hline $\mathrm{Fe}_{2} \mathrm{O}_{3}$ & 1.29 & demag. & 58.1 & \\
\hline $\mathrm{FeO}$ & 8.52 & Stable Inclination & 63.9 & \\
\hline MgO & 7.47 & & & \\
\hline $\mathrm{CaO}$ & 11.48 & Other Data: & $97 \mathrm{~cm}$ & $115 \mathrm{~cm}$ \\
\hline $\mathrm{Na}_{2} \mathrm{O}$ & 3.29 & Therm. cond. & & \\
\hline $\mathrm{K}_{2} \mathrm{O}$ & 0.54 & (mcal $\left./ \mathrm{cm} \cdot{ }^{\circ} \cdot \mathrm{C}\right)$ & 3.51 & 3.64 \\
\hline
\end{tabular}



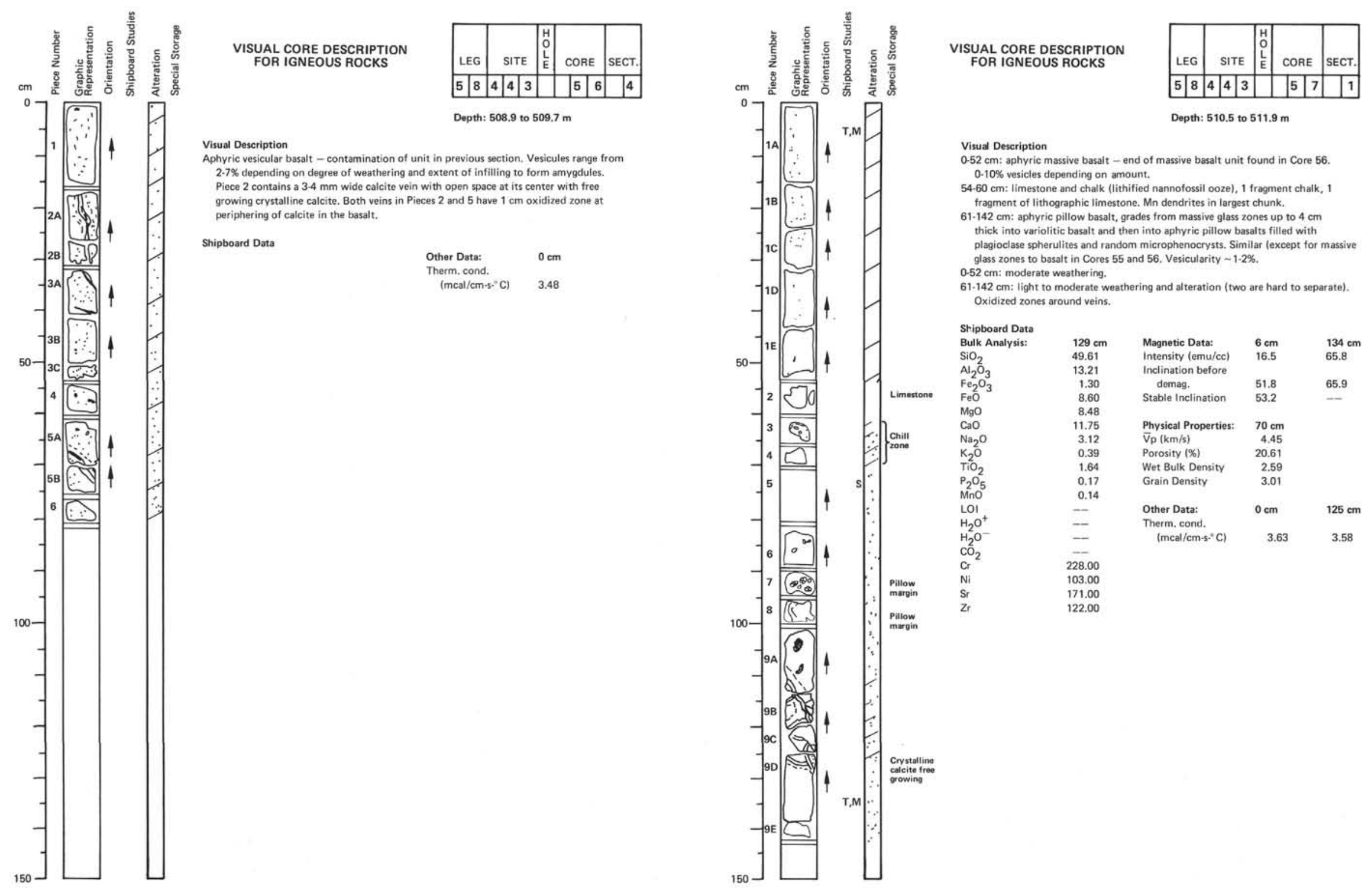

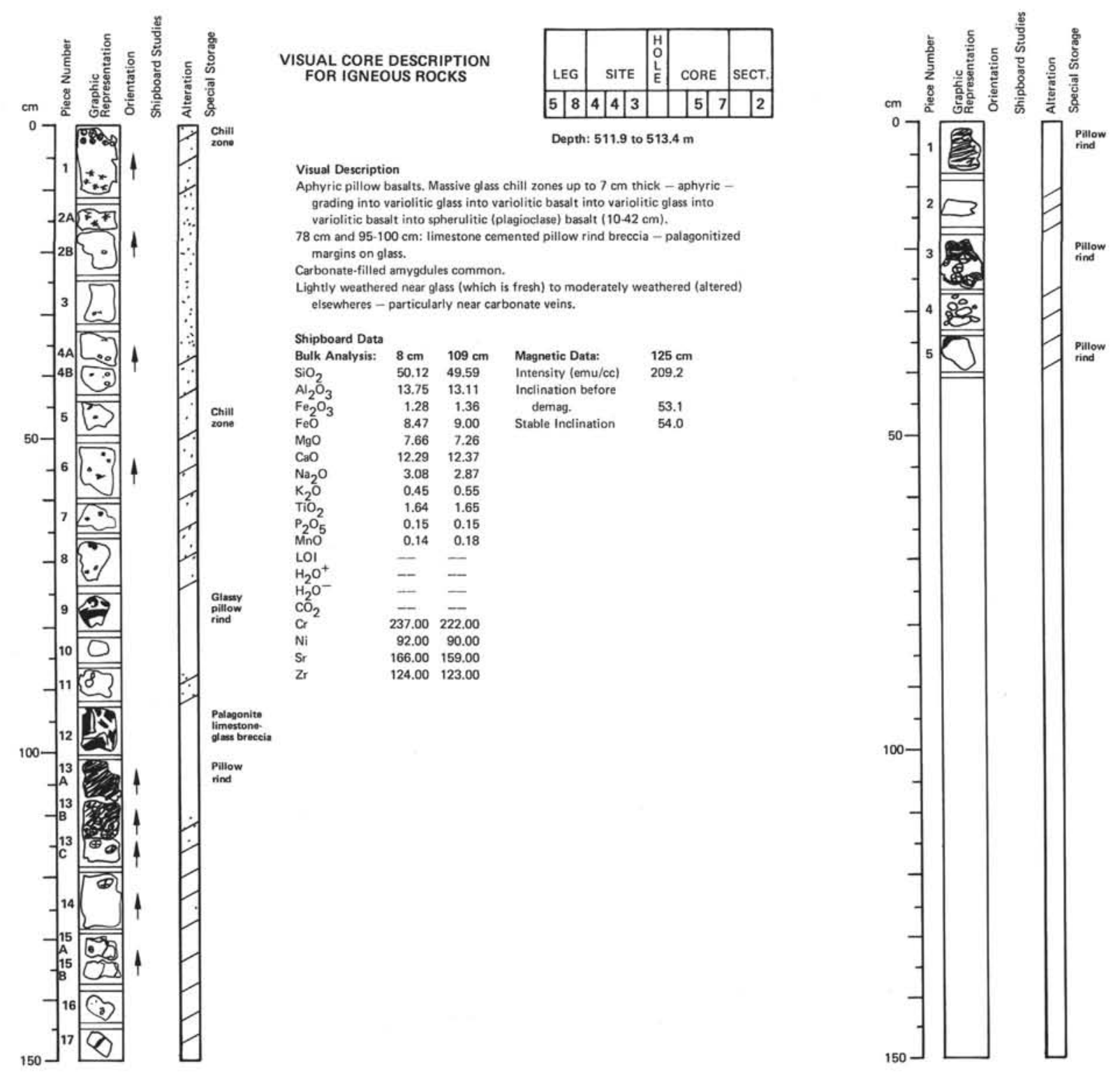
VISUAL CORE DESCRIPTION FOR IGNEOUS ROCKS

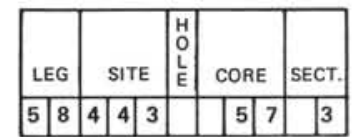
Depth: 513.4 to $513.8 \mathrm{~m}$

Visual Description

Aphyric pillow basalt with thick glass rinds $0.7 \%$ vesicles. Some pal aponitization of glass. 


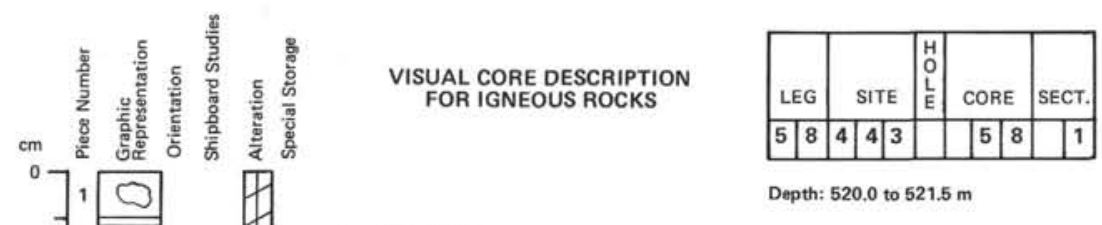

Visual Description

$3 \mathrm{~mm}$.
$24.150 \mathrm{~cm}$ : interior part the same flow.

Entire section has calcite veins with hydrooxide of iron.

70-120 cm: rare spherulites of plagioclase, $1-2 \%$, up to $5-7 \mathrm{~mm}$

\section{Shipboard Data
Bulk Analysis:}

$\mathrm{SiO}_{2}$

$\mathrm{Al}_{2} \mathrm{O}_{3}$

$\mathrm{Fe}_{2} \mathrm{O}_{3}$

$\mathrm{MgO}$

$\mathrm{MgO}$

$\mathrm{Na}_{2} \mathrm{O}$

$\mathrm{TiO}_{2}$

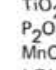

$\mathrm{LOI}$
$\mathrm{H}_{2} \mathrm{O}^{+}$
$\mathrm{H}_{2} \mathrm{O}^{-}$

$\mathrm{H}_{2}$

$\mathrm{CO}_{2}$
$\mathrm{Cr}$
$\mathrm{Ni}$
$\mathrm{Sr}$
$\mathrm{Zr}$

Intensity (emu/cc) $\quad 306.2$

Other Data:

$82 \mathrm{~cm}$

Therm. cond.

3.57

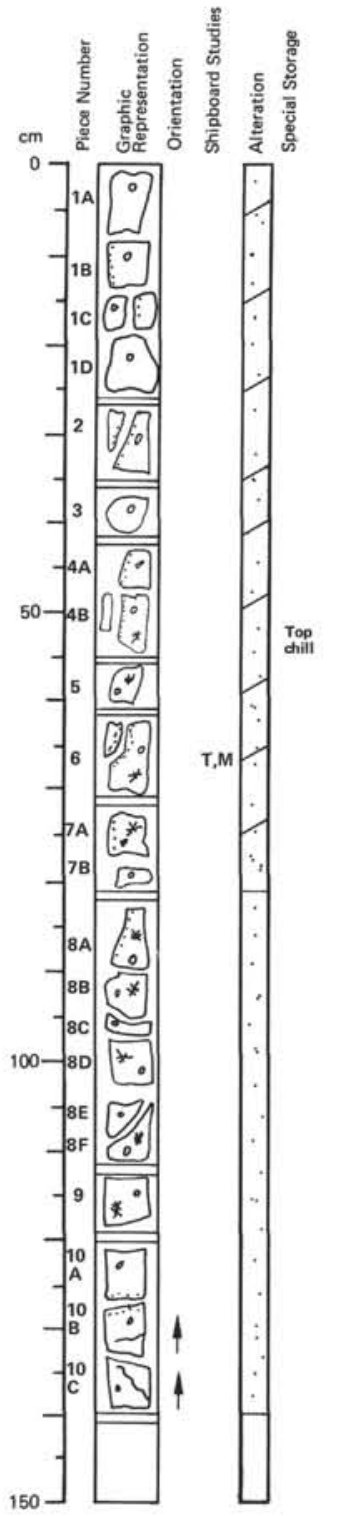

UAL CORE DESCRIPTION

FOR IGNEOUS ROCKS

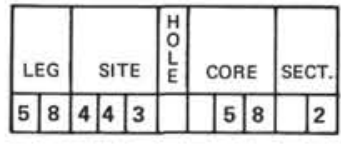

Depth: 521.5 to $522.9 \mathrm{~m}$

Visual Description

F5 cm: basalt identical to that described at the base of Core 58 , Section 1. Vesicles

$56.70 \mathrm{~cm}$ : chill zone of next lava flow (rim glass is absent). Basalt aphyric, dense, 70-140 cm: basalt aphyric fine-grained

.

$50.120 \mathrm{~cm}$; spherulites of plagioclase $1.2 \%$, up to $5 \mathrm{~mm}$. Vein with calcite and chlorite(7).

Shipboard Data

SiO $\quad 99 \mathrm{~cm}$

$\mathrm{Al}_{2} \mathrm{O}_{3}$

50.69
14.38

Magnetic Data:

$\begin{array}{cr}\text { demag. } & 65.5 \\ \text { Stable Inclination } & 64.6\end{array}$

$\mathrm{FeO}$

$\mathrm{MgO}$

1.20
7.95

demag.

$67 \mathrm{~cm}$
254.4

72.2
72.8

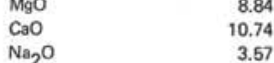

$\begin{array}{ll}3.57 \\ \mathrm{~K}_{2} \mathrm{O} & 0.26 \\ \mathrm{~T}_{2} & 0.26\end{array}$

$\begin{array}{ll}\mathrm{P}_{2} \mathrm{O}_{5} & 1.76 \\ \mathrm{PMO}_{2} & 0.17 \\ \mathrm{MnO} & 0.10\end{array}$

$\mathrm{H}_{\mathrm{H}_{2} \mathrm{O}^{+}}^{\mathrm{LO}}=$

$\mathrm{H}_{\mathrm{CO}_{2}}$

\begin{tabular}{ll} 
& \\
$\mathrm{Ni}$ & 73.00 \\
\hline & 73800
\end{tabular}

$\begin{array}{ll}\mathrm{St} & 178.00 \\ \mathrm{Zr} & 126.00\end{array}$ 

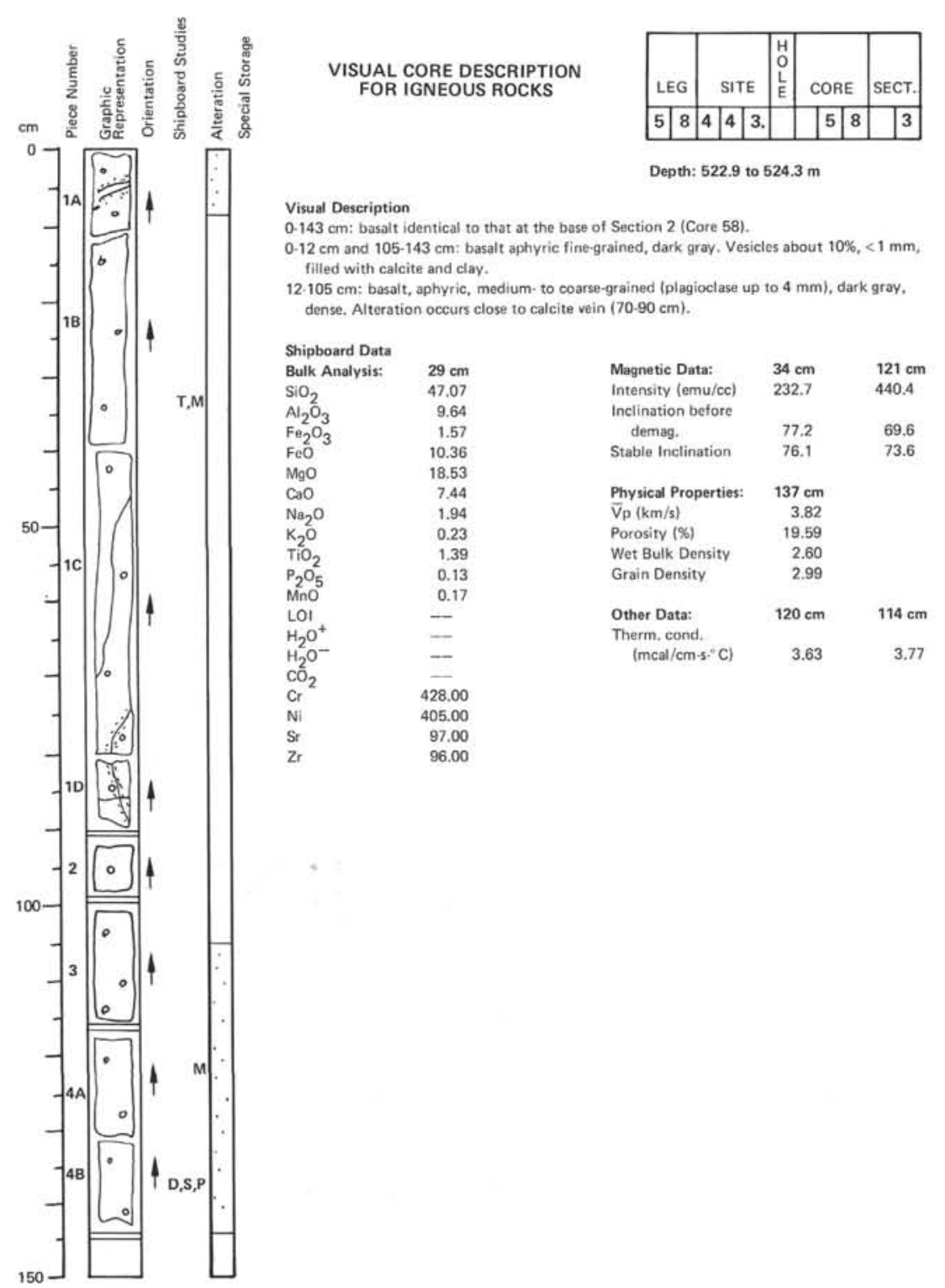

Visual Description

Depth: 522.9 to $524.3 \mathrm{~m}$

identical to that at the base of Section 2 (Core 58 ).

$0.12 \mathrm{~cm}$ and $105-143 \mathrm{~cm}$ : basalt aphyric fine-grained, dark gray. Vesicles about $10 \%,<1 \mathrm{~mm}$ filled with calcite and clay.

. dense. Alteration occurs close to calcite vein $(70.90 \mathrm{~cm}$.

\section{Shipboard Dats}

$\begin{array}{ll}\text { Bulk Analysis: } & 29 \mathrm{~cm} \\ \mathrm{SiO}_{2} & 47.07\end{array}$

$\begin{array}{lr}\mathrm{Si}_{2} & 47.07 \\ \mathrm{Al}_{2} \mathrm{O}_{3} & 9.64 \\ & \end{array}$

$\begin{array}{ll}\mathrm{Al}_{2} \mathrm{O}_{3} & 9.64 \\ \mathrm{Fe}_{2} \mathrm{O}_{3} & 1.57 \\ \mathrm{Fe} & 10.36\end{array}$

$\mathrm{MgO}$

$\mathrm{CaO}$

$\begin{array}{ll}\mathrm{TrO}_{2} & 1.39 \\ \mathrm{P}_{2} \mathrm{O}_{5} & 0.13\end{array}$

0.17

$\mathrm{H}_{2} \mathrm{O}^{+}=$

$\mathrm{H}_{2} \mathrm{H}_{2}=$

$\begin{array}{ll}\mathrm{Cr}^{2} & 428.00 \\ \mathrm{Ni} & 405.00\end{array}$

$\begin{array}{rr}\mathrm{Ni} & 405.00 \\ \mathrm{Sr} & 97.00\end{array}$

$\begin{array}{ll}\mathrm{Sr} & 97.00 \\ \mathrm{Zr} & 96.00\end{array}$

\begin{tabular}{|c|c|c|}
\hline Magnetic Data: & $34 \mathrm{~cm}$ & $121 \mathrm{~cm}$ \\
\hline Intensity (emu/cc) & 232.7 & 440.4 \\
\hline Inclination be & & \\
\hline $\begin{array}{l}\text { demag. } \\
\text { Stable Inclination }\end{array}$ & $\begin{array}{l}77.2 \\
76.1\end{array}$ & $\begin{array}{l}69.6 \\
73.6\end{array}$ \\
\hline Physical Properties: & $137 \mathrm{~cm}$ & \\
\hline $\bar{v}_{p}(\mathrm{~km} / \mathrm{s})$ & 3.82 & \\
\hline Porosity (\%) & 19.59 & \\
\hline Wet Bulk Density & 2.60 & \\
\hline Grain Density & 2.99 & \\
\hline Other Data: & $120 \mathrm{~cm}$ & $114 \mathrm{~cm}$ \\
\hline $\begin{array}{l}\text { Therm, cond. } \\
\left(\mathrm{mcal} / \mathrm{cm} \cdot \mathrm{s}^{\circ} \mathrm{C}\right)\end{array}$ & 3.63 & 3.77 \\
\hline
\end{tabular}

Therm, cond.

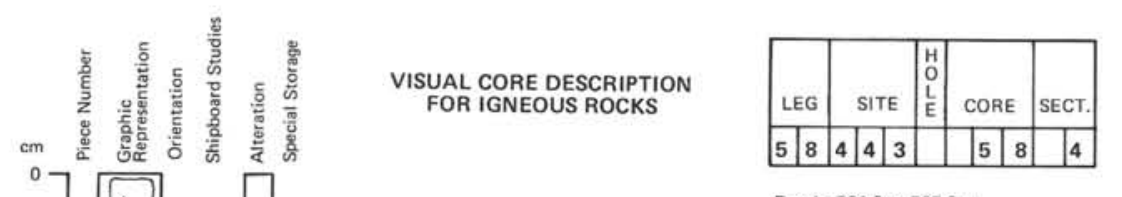

$\begin{array}{ll}\mathrm{K}_{2} \mathrm{O} & 1.94 \\ \mathrm{~T}^{\mathrm{O}} & 0.23\end{array}$

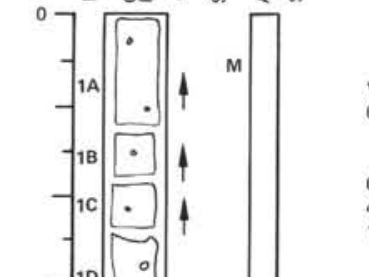

Visual Description

(T) base of Section 3 (Core 58). Basalt aphyric, . $0.45 \mathrm{~cm}:$ fresh

5-125 cm: basalt is altered, greenish gray. Vesicles partly are filled with clay $(25.125 \mathrm{~cm}$. $25.150 \mathrm{~cm}$. pillow tava with glass rim. Basalt dense, Close to rim color is greenish.gray, $3 \mathrm{~cm}$ in from rim color is gray. Very rare phenocryst of plagioclase $(1 \mathrm{~mm})$.

Shipboard Dat

Bulk Analysis: $\quad 30 \mathrm{~cm}$

$\begin{array}{ll}\mathrm{SiO}_{2} & 51.03 \\ \mathrm{Al}_{2} \mathrm{O}_{3} & 13.33 \\ & 1.23\end{array}$

13.33
1.23
8.12

$\begin{array}{ll}6 \mathrm{~cm} & 34 \mathrm{~cm} \\ 282.6 & 273.0\end{array}$

$\mathrm{FeO}$

$\mathrm{MgO}$

$\begin{array}{ll}\mathrm{Na}_{2} \mathrm{O} & 3.28 \\ \mathrm{~K}_{2} \mathrm{O} & 0.30\end{array}$

$\begin{array}{ll}\mathrm{K}_{2} \mathrm{O}_{2} & 0.30 \\ \mathrm{TiO}_{2} & 1.86 \\ \mathrm{P}_{2} \mathrm{O}_{5} & 0.19\end{array}$

$\mathrm{MnO} \quad 0.10$

LoI

$\mathrm{H}_{2} \mathrm{O}^{+}$
$\mathrm{H}_{2} \mathrm{O}^{-}$

$\begin{array}{ll}\mathrm{CO}_{2} & - \\ \mathrm{Cr}_{2} & -\end{array}$

$\begin{array}{ll}\mathrm{Cr} & 246.00 \\ \mathrm{Ni} & 115.00 \\ \mathrm{Sr} & 154.00 \\ \mathrm{C} & 13.00\end{array}$

$\begin{array}{ll} & 154.00 \\ \mathrm{Zr} & \quad 138.00\end{array}$ $\begin{array}{lll}\text { demag. } & 69.4 & 71.0 \\ & \end{array}$
$\mathrm{CaO} \quad 9.27$ 


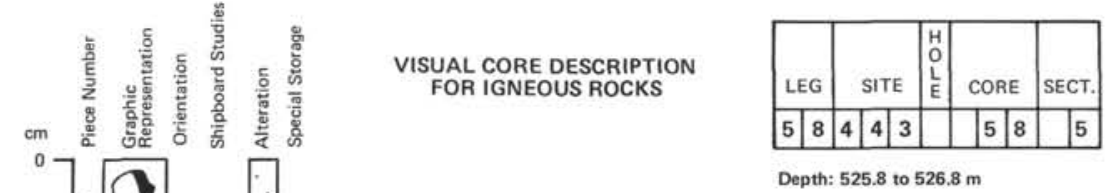

Visual Description

(1) is the upper part of 1095 com:

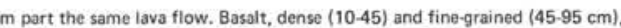
Gark gray, aphyric. Alteration close to calcite. Vein is very slight.

Shipboard Data

Magnetic Date:

412

Inclinetion before

-51.9
-50.2

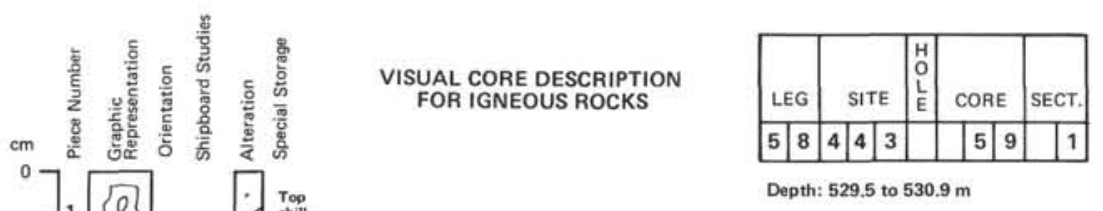

Visual Description

$0.8 \mathrm{~cm}$ : basalt of top chill zone. Aphyric, dense, gray, with large open vesicles $(1-3 \mathrm{~cm})$.

8. $144 \mathrm{~cm}$ : basalt, aphyric, dense, brown gray,

Calcite vein without alteration (with slight alteration).

28-4i cm: sedimentary carbonate.

Shipboard Data

Bulk Analysis: $\quad 71 \mathrm{~cm} \quad 129 \mathrm{~cm} \quad$ Magnetic Data: $\quad 12 \mathrm{~cm}$

$\mathrm{SiO}_{2} \quad 49.68 \quad 49.86$

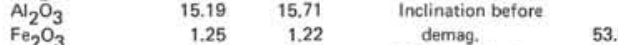

$\begin{array}{llll}1.25 & 1.22 & \text { demag. } & \\ 8.24 & 8.03 & \text { Stable Inclination } & 43.8\end{array}$

$\begin{array}{lrr}\mathrm{MgO} & 6.69 & 7.82\end{array}$

$\begin{array}{rrr}\mathrm{Ca}_{2} \mathrm{O} & 13.05 & 12.18 \\ \mathrm{~N}_{2} \mathrm{O} & 3.11 & 3.17 \\ & 0.35 & 1.32\end{array}$

$\begin{array}{lll}\mathrm{Na}_{2} \mathrm{O} & 3.11 & 3.17 \\ \mathrm{~K}_{2} \mathrm{O} & 0.34 & 0.37 \\ & 1.30 & 1.32\end{array}$

$\begin{array}{lll}\mathrm{TiO}_{2} & 1.30 & 1.22 \\ \mathrm{PO}_{2} \mathrm{O}_{5} & 0.11 & 0.11\end{array}$

\begin{tabular}{lll}
$\mathrm{MnO}^{2}$ & 0.18 & 0.17 \\
\hline
\end{tabular}

$\mathrm{LOI}^{+}$

$\mathrm{H}_{2} \mathrm{O}^{+}$

$\mathrm{CO}_{2}-\quad-$

$\begin{array}{lrr}\mathrm{C} & 286.00 & 285.00 \\ \mathrm{Ni} & 92.00 & 100.00 \\ \mathrm{Si} & 17300 & 10500 \\ \mathrm{Z} & 9000 & 8000\end{array}$

$\begin{array}{rrr} & & 97 \\ \mathrm{Zr} & 90.00 & 165.00 \\ & & 88.00\end{array}$ 

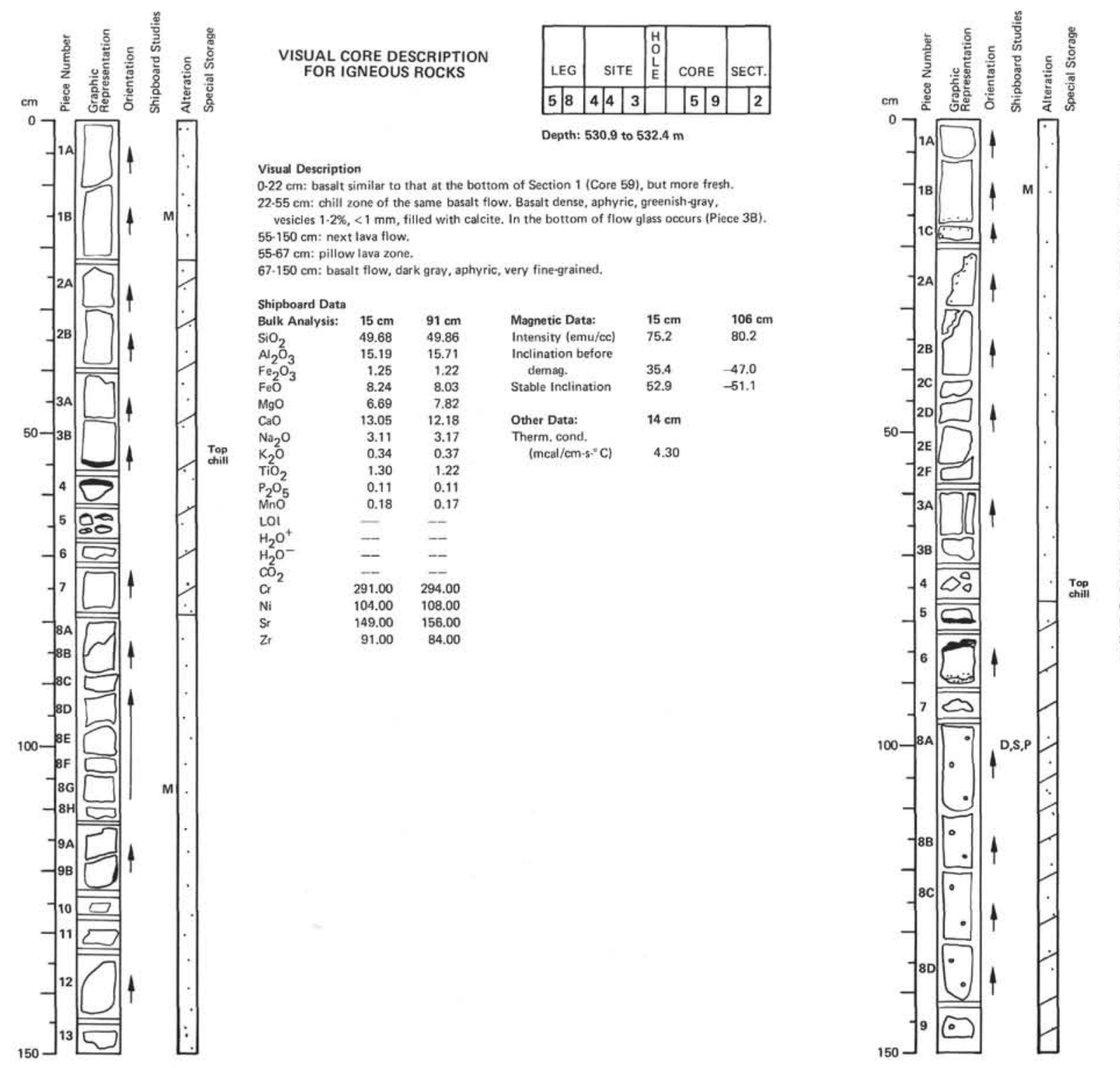

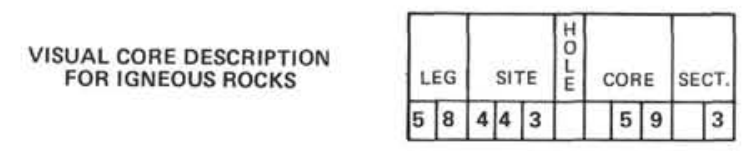

Depth: 532.4 to $533.9 \mathrm{~m}$

Visual Description

(her to that at the bottom (base) of Section 2 (Core 59). $20.76 \mathrm{~cm}$ : the same lava flow but basalt is dense, phyric, yellow gray, alteration close calcite vein is low.

$76.90 \mathrm{~cm}$ : chill margin (top) of lava flow with rims of glass.

o. $-50 \mathrm{~cm}$ : basalt, fine-grained, aphyric, greenish-gray, vesicular. Vesicles $10.15 \%$,

Shipboard Data
Bulk Analysis:

$\begin{array}{lllll}\text { Bulk Analysis: } & 4 \mathrm{~cm} & 101 \mathrm{~cm} & \text { Magnetic Data: } & 12 \mathrm{~cm} \\ \mathrm{SiO}_{2} & 49.90 & 49.85 & \begin{array}{l}\text { Intensity (emu/ccl } \\ 4.2\end{array} & 44.2\end{array}$

$\begin{array}{llll}\mathrm{Al}_{2} \mathrm{O}_{3} & 15.71 & 49.85 & \text { intensity }(\mathrm{emu} / \mathrm{Coc}) \\ \text { Inclination before }\end{array}$

$\begin{array}{lll}\mathrm{Fe}_{2} \mathrm{O}_{3} & 1.18 & 1.19\end{array}$

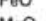

$\mathrm{MgO}$

$\mathrm{CaO}$

$\mathrm{Na}_{2} \mathrm{O} \quad 3.11$

$\begin{array}{ll}7.79 & 7.88 \\ 9.48 & 9.05\end{array}$

$\begin{array}{rr}11.69 & 11.78 \\ 3.11 & 3.18\end{array}$

$0.13 \quad 0.27$

$\begin{array}{ll}1.25 & 1.29 \\ 0.09 & 0.09\end{array}$

$\begin{array}{lll}\mathrm{P}_{2} \mathrm{O}_{5} & 0.09 & 0.09 \\ \mathrm{MnO} & 0.13 & 0.13\end{array}$

$\begin{array}{lll}\mathrm{LOI} & - & -\end{array}$

$\begin{array}{lll}\mathrm{CO}_{2} & - & - \\ \mathrm{Cr}^{2} & - & \end{array}$

$\begin{array}{lll}\mathrm{Ni} & 113.00 & 145.00 \\ \mathrm{Si} & & \end{array}$

$\begin{array}{lll}\mathrm{Sr} & 15.00 & 150.00 \\ \mathrm{Zr} & 87.00 & 91.00\end{array}$

$\begin{array}{cr}\text { demog. } & -6.5 \\ \text { Stable Inclination } & -53.6\end{array}$

Physical Properties: $\quad 98 \mathrm{~cm}$

Grain Density

Other Data:

(mcal/cm-s. ${ }^{\circ} \mathrm{C}$

4.08 

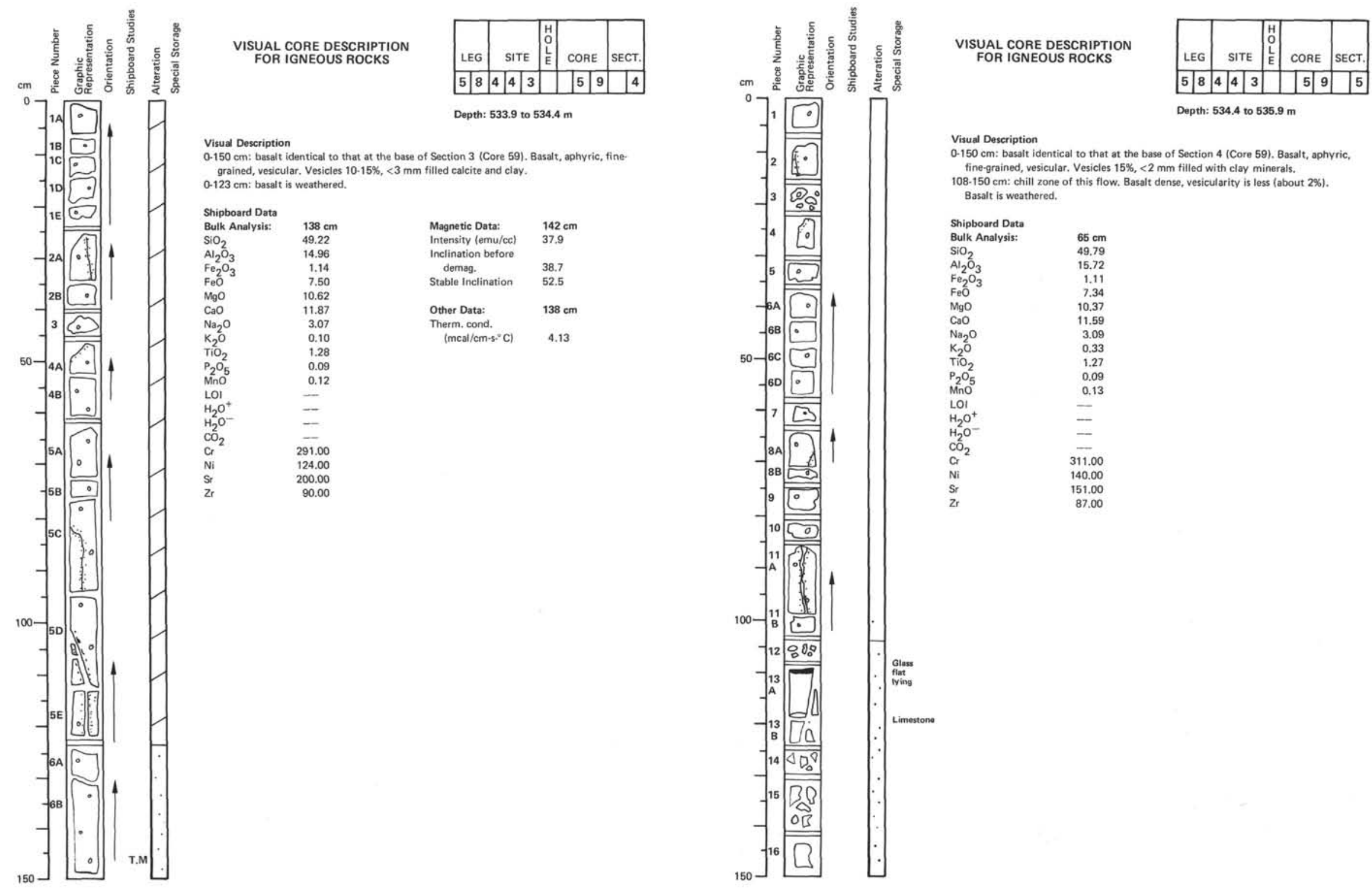

Depth: 534.4 to $535.9 \mathrm{~m}$

Visual Description .

列

\begin{tabular}{|c|c|c|c|}
\hline & $138 \mathrm{~cm}$ & Magnetic Data: & \\
\hline $\mathrm{SiO}_{2}$ & 49.22 & Intensity (emu/cc) & 37.9 \\
\hline $\mathrm{Al}_{2} \mathrm{O}_{3}$ & 14.96 & Inclination before & \\
\hline & & & 38.7 \\
\hline & 7.50 & Stable Inclination & 52.5 \\
\hline $\mathrm{Mg}_{8} \mathrm{O}$ & 10.62 & & \\
\hline $\mathrm{CaO}$ & 11.87 & Other Data: & $138 \mathrm{~cm}$ \\
\hline $\mathrm{Na}_{2} \mathrm{O}$ & 3.07 & Therm. cond. & \\
\hline $\mathrm{K}_{2} \mathrm{O}$ & 0.10 & $\left(\mathrm{mcal} / \mathrm{cm} \cdot \mathrm{s}^{\circ} \mathrm{C}\right)$ & 4.13 \\
\hline $\mathrm{TiO}_{2}$ & 1.28 & & \\
\hline $\mathrm{P}_{2} \mathrm{O}_{5}^{2}$ & 0.09 & & \\
\hline Mno & 0.12 & & \\
\hline LOI, & - & & \\
\hline $\mathrm{H}_{2} \mathrm{O}^{+}$ & - & & \\
\hline $\begin{array}{l}\mathrm{H}_{2} \mathrm{O}^{-} \\
\mathrm{CO}^{2}\end{array}$ & $\overline{-}$ & & \\
\hline $\begin{array}{l}\mathrm{CO}_{2} \\
\mathrm{Cr}\end{array}$ & 291.00 & & \\
\hline $\mathrm{Ni}$ & 124.00 & & \\
\hline St & 200.00 & & \\
\hline $\mathrm{Zr}$ & 90.00 & & \\
\hline
\end{tabular}




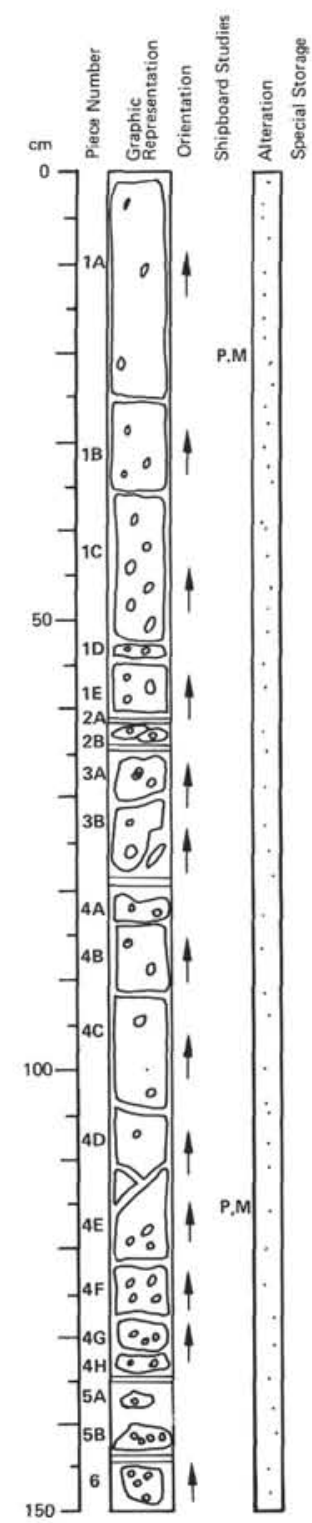

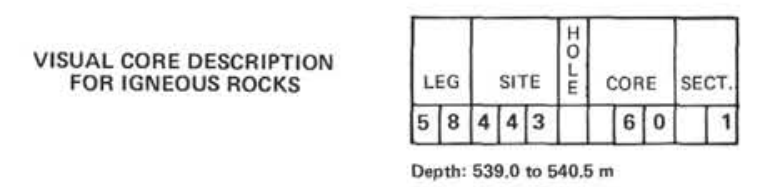

Visual Description

Gray, aphyric, medium-grained (approximately $0.5 \mathrm{~mm}$ to $1 \mathrm{~mm}$ ) basalt, containing pyroxene and plagioclase.
Amygdules filled by talc/chlorite/smectite type mineral and pyrite grains. Talc/smectite material and pyrite grains also line fractures at $26 \mathrm{~cm}$ (between Piece $T A$ and $1 B$ ) and at $110 \mathrm{~cm}$ (between Piece 10 and $1 E)$

Amygdules approximately $15.30 \%(1 \mathrm{~mm}-10 \mathrm{~mm}$ across).

thaped mineral and white cylindrical (wire-like) mineral in some amygdules (zeolites?).

Thin Section Description - $112 \mathrm{~cm}$

Phenocrysts: Spinel, $0.02 \mathrm{~mm}$, light spinel square grain, 1 grain seen in olivine.

(a) granular: other $25 \%$ cryptocrystalline matrix.

0.7.2.0 mm

Shipboard Data

$\begin{array}{lrrlll}\text { Shipboard Data } & & & & & \\ \text { Bulk Analysis: } & 21 \mathrm{~cm} & 80 \mathrm{~cm} & \text { Magnetic Data: } & 15 \mathrm{~cm} & 111 \mathrm{~cm} \\ \mathrm{SiO}_{2} & 48.99 & 49.41 & \text { Intensity (emu/ } / \mathrm{c} \text { ) } & 75.1 & 95.6 \\ \mathrm{Al}_{2} \mathrm{O}_{3} & 14.89 & 14.87 & \text { Inclination before } & & \\ \mathrm{Fe}_{2} \mathrm{O}_{3} & 1.18 & 1.20 & \text { demag. } & 62.0 & 43.9 \\ \mathrm{FeO}^{2} \mathrm{O} & 7.79 & 7.94 & \text { Stable Inclination } & 49.5 & 51.0\end{array}$

$\begin{array}{llllll}\mathrm{Fe}_{2} \mathrm{O}_{3} & 1.18 & 1.20 & \text { demag. } & 62.0 & 43.9 \\ \mathrm{FeO} \mathrm{O} & 7.79 & 7.94 & \text { Stable Inclination } & 49.5 & 51.0\end{array}$

$\begin{array}{lllll}\mathrm{MgO} & 11.29 & 11.21 & & \\ \mathrm{CaO} & 10.96 & 10.72 & \text { Other Data: } & 0 \mathrm{~cm}\end{array}$

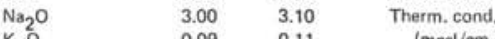

(mcal/om-s." C)

4.46

$\begin{array}{lll}\mathrm{TiO}_{2} & 1.21 & 1.25 \\ \mathrm{P}_{2} \mathrm{O}_{5} & 0.09 & 0.09\end{array}$

$\begin{array}{lll}\mathrm{MnO}^{2} & 0.16 & 0.16\end{array}$

$\begin{array}{ll}\mathrm{LOI}_{2} \mathrm{O}^{+} & - \\ \mathrm{H}^{-} & -\end{array}$

$\begin{array}{lll}\mathrm{H}_{2} \mathrm{O}^{-} & - & -\cdots \\ \mathrm{CO}_{2} & - & -1 \\ \mathrm{Cr}^{2} & - & -1.00\end{array}$

$\begin{array}{lll}\mathrm{Ni} & 122.00 & 124.00 \\ \mathrm{Si} & 142.00 & 144.00 \\ \mathrm{Z} & & \end{array}$

$\begin{array}{lrr}\text { Sr } & 142.00 & 144.00 \\ \mathrm{Zr} & .85 .00 & 91.00\end{array}$

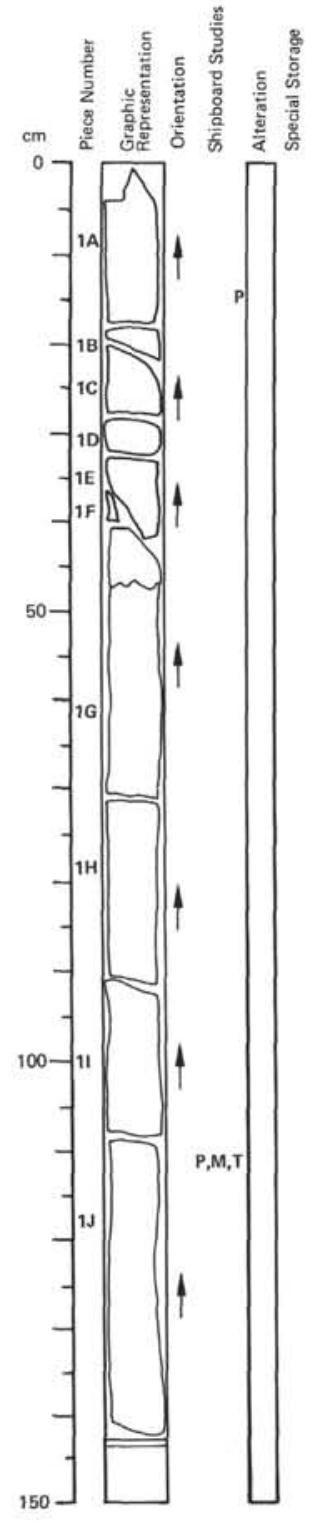

VISUAL CORE DESCRIPTION FOR IGNEOUS ROCKS

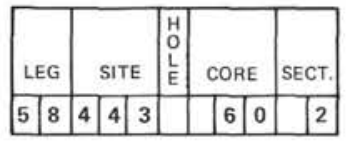

Depth: 540.5 to $541.9 \mathrm{~m}$

Visual Description

(a)

$0.42 \mathrm{~cm}$ : $25 \%$ amydules filled by green grav or white talc/chlorite/smectite material. Similer material lines vein between 33 and $53 \mathrm{~cm}$. Plus some fine pyrite above section similar to

previous corte except no pyrite seen in amygdules.

acm: gray, aphyric, medium-grained basalt as above but virtually no amygdules

Thin Section Description $-111 \mathrm{~cm}$

$20 \%, 0.2 .0 .6 \mathrm{~mm}$, anhedral; plagioclase $45 \%, 0.1 .20 \mathrm{~mm}$, laths

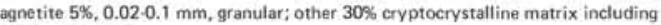
acicular pyroxene.

Ateration: other in groundmass replacing olivine?, talc, ?fibrous.

Shipboard Data

Bulk Analysis:

$106 \mathrm{~cm}$
49.28
14.94
1.22
8.08

Magnetic Data: Motensity (emu/cc) $\quad 110 \mathrm{~cm}$ Inclination before

$\begin{array}{cr}\text { demag. } & 36.7 \\ \text { Stable Inclination } & 47.3\end{array}$

Physical Properties: $8 \mathrm{~cm}$

Wet Bulk Density $\quad 2.75$

Grain Density 2.98

Other Data:

$8 \mathrm{~cm} \quad 134 \mathrm{~cm}$

Lol $\quad-$

$\mathrm{H}_{\mathrm{H}_{2} \mathrm{O}^{+}}^{\mathrm{O}^{+}}=$

(mcal/cm-s. 0

$4.37 \quad 4.27$ 


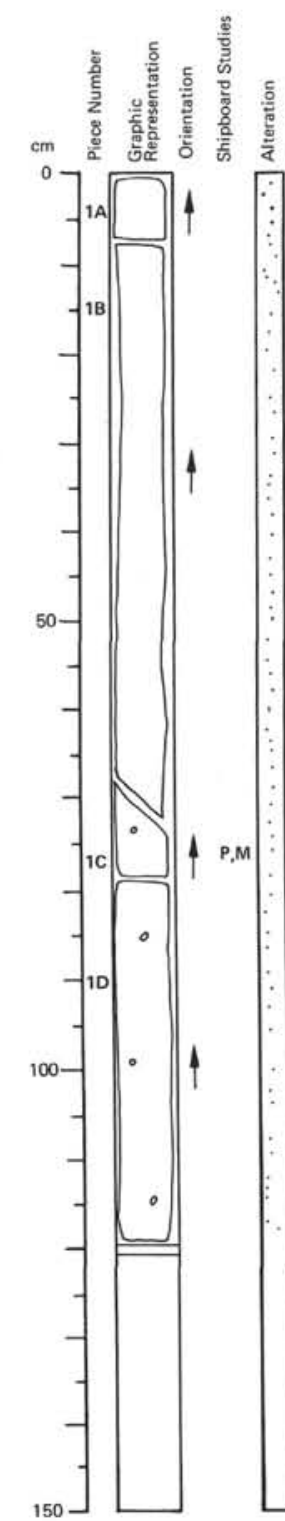

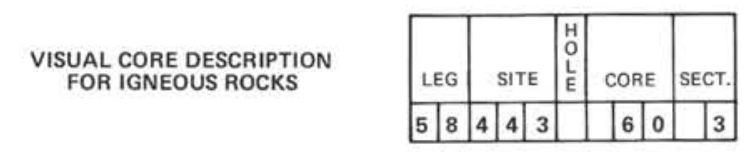

Visual Description

basalt containing plagioclase and pyroxene vein between mall number of anvis $1 \%,<2 \mathrm{~mm}$ across). Upper part $(0.70 \mathrm{~cm})$ similar to lower part of previous section. A few odd grains (very fine) of pyrite seen in some amygdules.

Shipboard Data $\begin{array}{ll}\text { Magnetic Data: } & 74 \mathrm{~cm} \\ \text { Intensity (emu/cc) } & 82.5\end{array}$ Inclination before Other Data: Therm. cond. 4.39

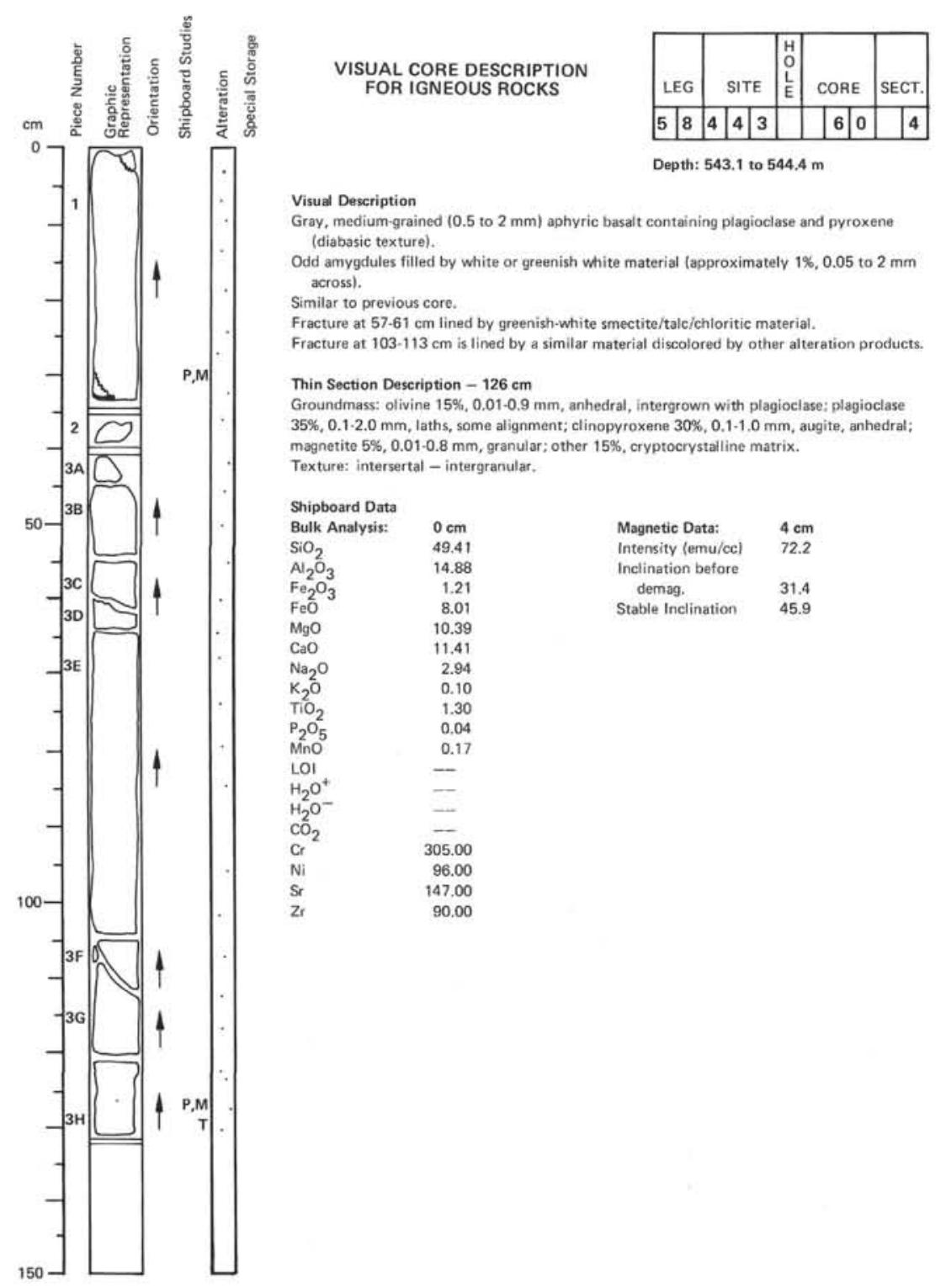




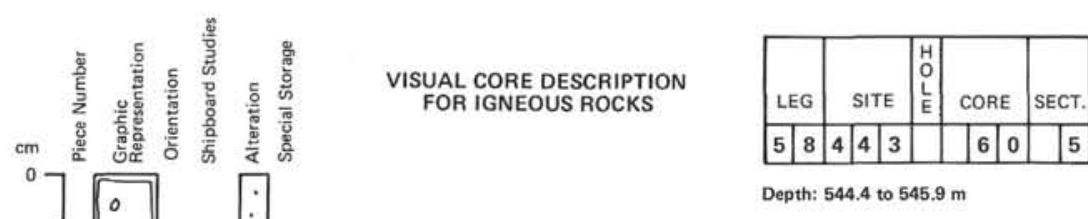

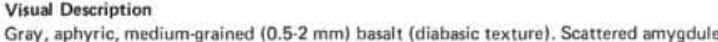
fillod by white material (generally $<1 \mathrm{~mm}$ across, $1.3 \%$, similar to previous section. vein along which rock fractured at $88 \mathrm{~cm}$ lined by white platey mineral and honey brown .

Shipboard Data

\begin{tabular}{lc}
\hline Physical Properties: & $113 \mathrm{~cm}$ \\
$\bar{V}_{p}(k m / s)$ & 5.64 \\
Porosity & 2.37 \\
Wet Bulk Density & 2.89 \\
Grain Density & 2.94
\end{tabular}

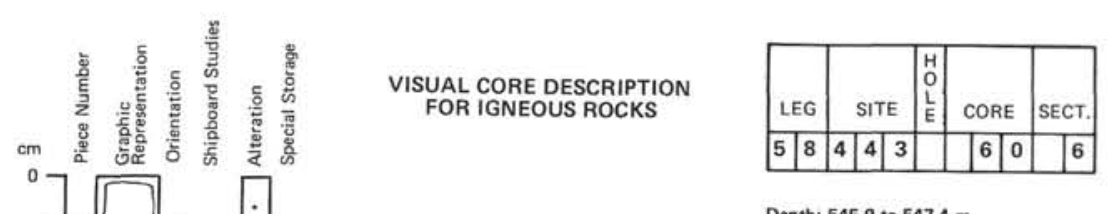

Depth: 545.9 to 547.4

Visual Description

Gray. uphy rc, medium-grained basalt $10.5-2 \mathrm{~mm} / \mathrm{montaining} \mathrm{plagioclase} \mathrm{and} \mathrm{pyroxene.}$ previous mall amygdules filled by white material $<1$, s.

Bulk Analysis: $\quad 104 \mathrm{~cm}$

$\begin{array}{ll}\mathrm{SiO}_{2} & 48.77 \\ \mathrm{Al}_{2} \mathrm{O}_{3} & 15.08\end{array}$

$\begin{array}{ll}\mathrm{Fe}_{2} \mathrm{O}_{3} & 1.18 \\ \mathrm{FeO} & 7.81\end{array}$

$\begin{array}{lr}\mathrm{MgO} & 11.81 \\ \mathrm{CaO} & 11.23\end{array}$

$\begin{array}{lr}\mathrm{CaO}^{\mathrm{O} O} & 11.23 \\ \mathrm{Na}_{2} \mathrm{O} & 2.95 \\ \mathrm{~K}_{2} \mathrm{O} & 0.21\end{array}$

$\begin{array}{ll}\mathrm{K}_{2} \mathrm{O} & 0.21 \\ \mathrm{TiO}_{2} & 1.16 \\ \mathrm{~T}_{2} & 0.03\end{array}$

$\begin{array}{ll}\mathrm{P}_{2} \mathrm{O}_{5} & 0.03 \\ \mathrm{MnO} & 0.16\end{array}$

$\begin{array}{ll}\mathrm{LOI} & - \\ \mathrm{L}_{2} \mathrm{O}^{+} & - \\ \mathrm{H}_{2} \mathrm{O}^{-} & -\end{array}$

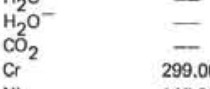

$\begin{array}{lr}\mathrm{Cr}^{2} & 299.00 \\ \mathrm{Ni} & 147.00 \\ \mathrm{Si} & 172.00 \\ \mathrm{Zr} & 82.00\end{array}$ 

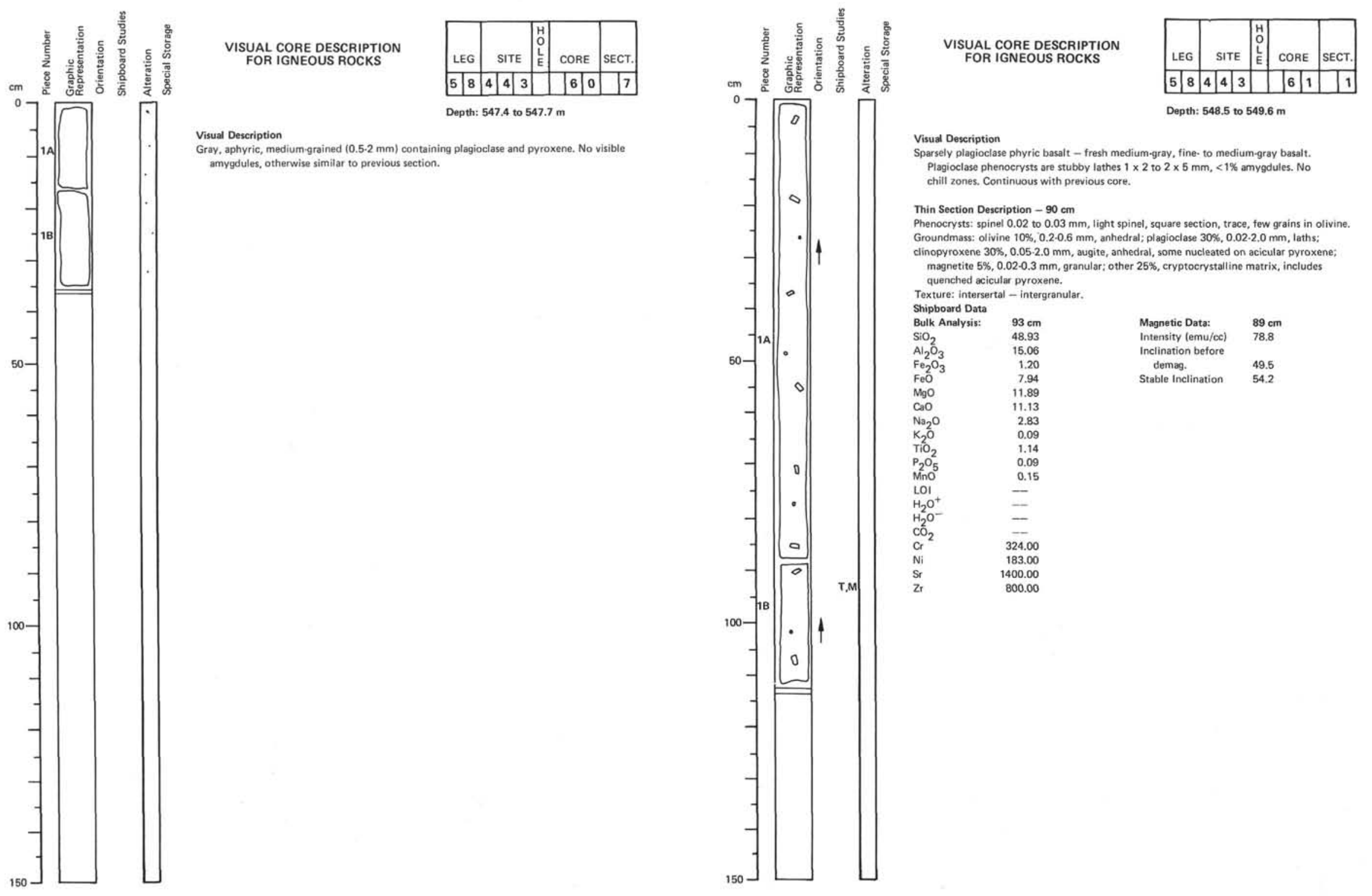


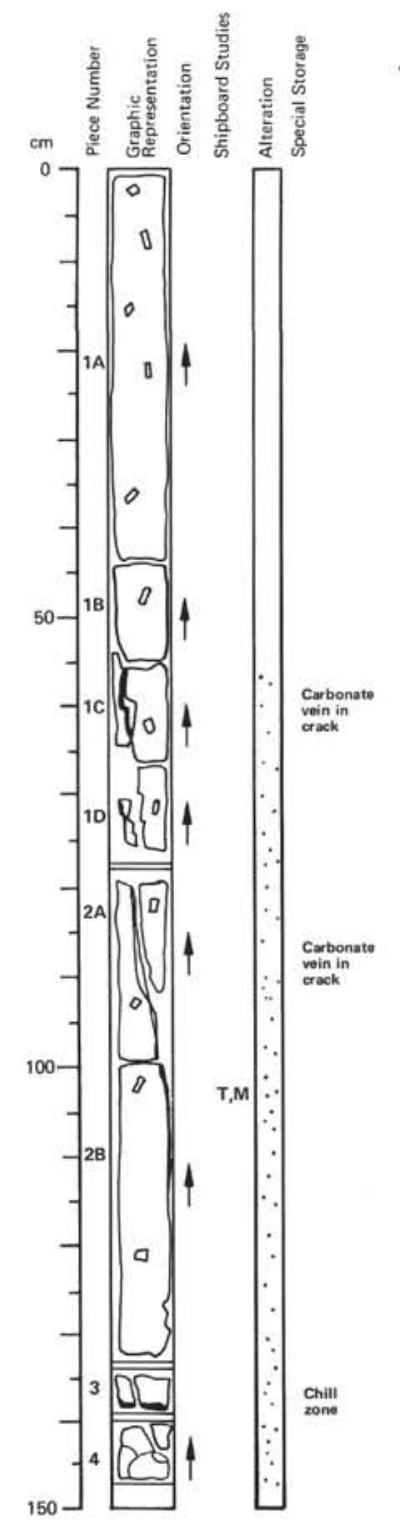

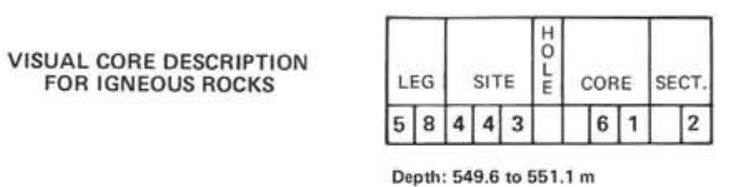

Visual Description

. Cariclase nenocrysts $2 \times 11 / 2$ to $3 \times 5 \mathrm{~mm}$. Slight lateration of plagioclase. Chill zone at $138 \mathrm{~cm}$.

$135.150 \mathrm{~cm}$ : aphanitic basalt very sparsely phyric to aphyric with a few scattered plagioclase phenocrysts.

Thin Section Description - $104 \mathrm{~cm}$

mm, anhedral; plagiocl ase $35 \%, 0.1 \cdot 1.5 \mathrm{~mm}$ , $30 \%$, $0.02 .8 \mathrm{~mm}$, augite, anhedral: $02.0 .2 \mathrm{~mm}$, granuiar; other $20 \%$ groundmass.

Texture: intersertal. other, groundmass, replacing olivine, chlorite, iddingsite, serpentine.

\section{Shipboard Data}

$\mathrm{SiO}_{2}$

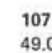

$\underset{\substack{107 \\ 49.03}}{40.03}$

$\begin{array}{ll}\text { Magnetic Data: } & 103 \mathrm{~cm} \\ \text { Intensity (emu/cc) } & 113.9\end{array}$

$\mathrm{Fe}_{2} \mathrm{O}_{3}$

15.14
1.21

demag.
Stable Inclinatio

Other Data:

(mcal/cm:s. ${ }^{\circ} \mathrm{C}$ )

56.4

$\begin{array}{rr}\mathrm{MgO} & 9.92 \\ \mathrm{CaO} & 11.95\end{array}$

4.34

$\begin{array}{ll}\mathrm{K}_{2} \mathrm{O} & 0.13 \\ \mathrm{TO}_{2} & 1.22 \\ \mathrm{P}_{2} \mathrm{O}_{2} & 0.09\end{array}$

$\begin{array}{ll}\mathrm{P}_{2} \mathrm{O}_{5} & 0.09 \\ \mathrm{MnO} & 0.15\end{array}$

$\mathrm{H}_{2} \mathrm{O}^{+}$
$\mathrm{H}_{2} \mathrm{O}^{-}$

$\begin{array}{ll}\mathrm{CO}_{2} & 299.00 \\ \mathrm{Cr}^{\mathrm{Ni}} & \end{array}$

$\begin{array}{ll}\mathrm{Ni} & 299.00 \\ \mathrm{Sr} & 127.00 \\ \mathrm{Cr} & 199.00\end{array}$

$\begin{array}{lr} & 199.00 \\ \mathrm{Zr} & 83.00\end{array}$

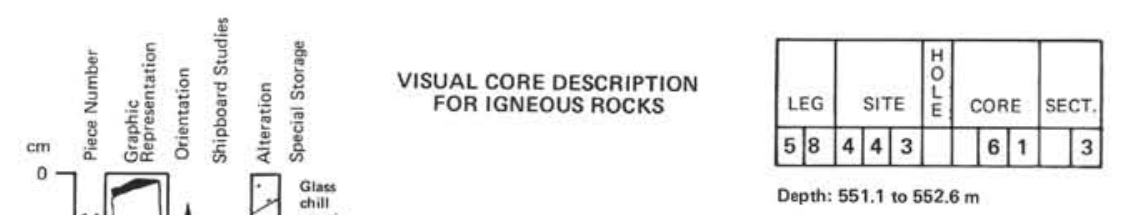

Visual Description

ned to aphanitic < $1 \%$ plagioclase phenocrysts, $1 \times 3$ to $2 \times 4 \mathrm{~mm}$ to light weathering Garbonat $80-120 \mathrm{~cm}$ with carbonate and smectite fillings moderate It is not clear as to whether these are thin flows or pillows.

Shipboard Data

Bulk Analysis: $\quad 13 \mathrm{~cm} \quad 29 \mathrm{~cm} \quad 101 \mathrm{~cm}$

$\begin{array}{llll}\mathrm{SiO}_{2} & 49.54 & 49.92 & 49.56 \\ \mathrm{Al}_{2} \mathrm{O}_{3} & 15.35 & 15.39 & 15.27\end{array}$

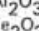

$\mathrm{FeO}^{-10}$

$\mathrm{MgO}$

$\mathrm{CaO}$
$\mathrm{Na}_{2} \mathrm{O}$
$\mathrm{K}_{2} \mathrm{O}$

$\mathrm{K}_{2} \mathrm{O}$

$\mathrm{P}_{2} \mathrm{O}_{5}$

LOI

$\mathrm{H}_{2} \mathrm{O}^{+}$

Glass
chill

$\mathrm{CO}_{2}$

$\begin{array}{rrr}1.35 & 15.39 & 15.27 \\ 1.20 & 1.20 & 1.20 \\ 7.94 & 7.92 & 7.93\end{array}$

$\begin{array}{lll}7.94 & 7.92 & 7.93 \\ 8.17 & 8.32 & 9.72\end{array}$

$\begin{array}{rrr}13.18 & 12.43 & 11.96 \\ 2.97 & 2.99 & 2.89\end{array}$

$\begin{array}{lll}0.25 & 0.25 & 0.08\end{array}$

$\begin{array}{lll}0.15 & 0.13 & 0.09\end{array}$

= $=$

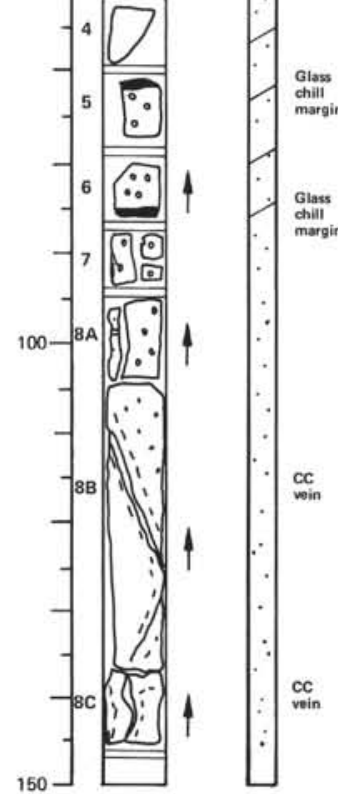

$\begin{array}{lll}302.00 & 304.00 & 308.00\end{array}$

$\begin{array}{lll}108.00 & 117.00 & 105.00 \\ 167.00 & 107.00 & 15.00\end{array}$

$\begin{array}{rrr}167.00 & \quad r 67.00 & 151.00 \\ 89.00 & 88.00 & 86.00\end{array}$

chass

win 

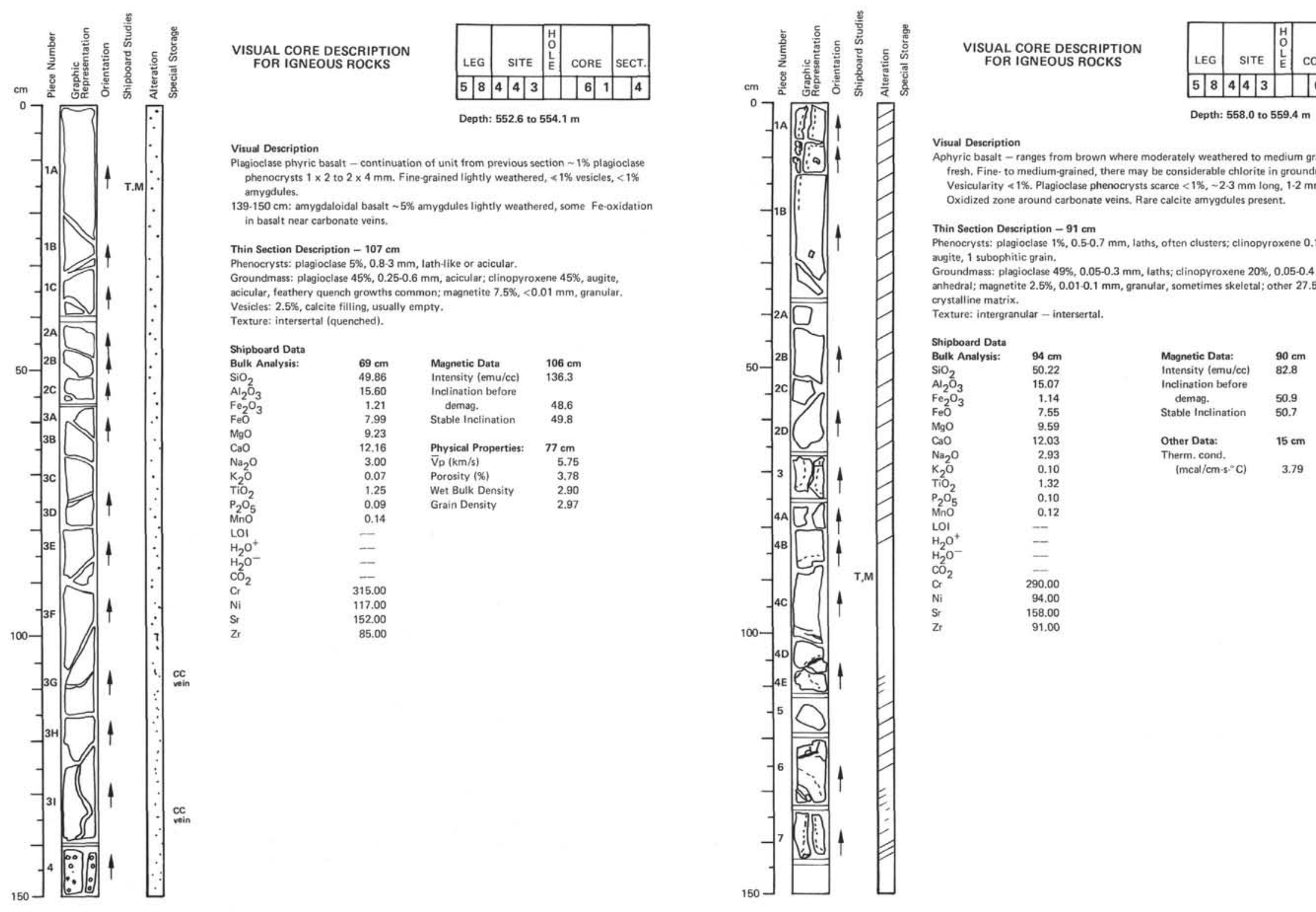

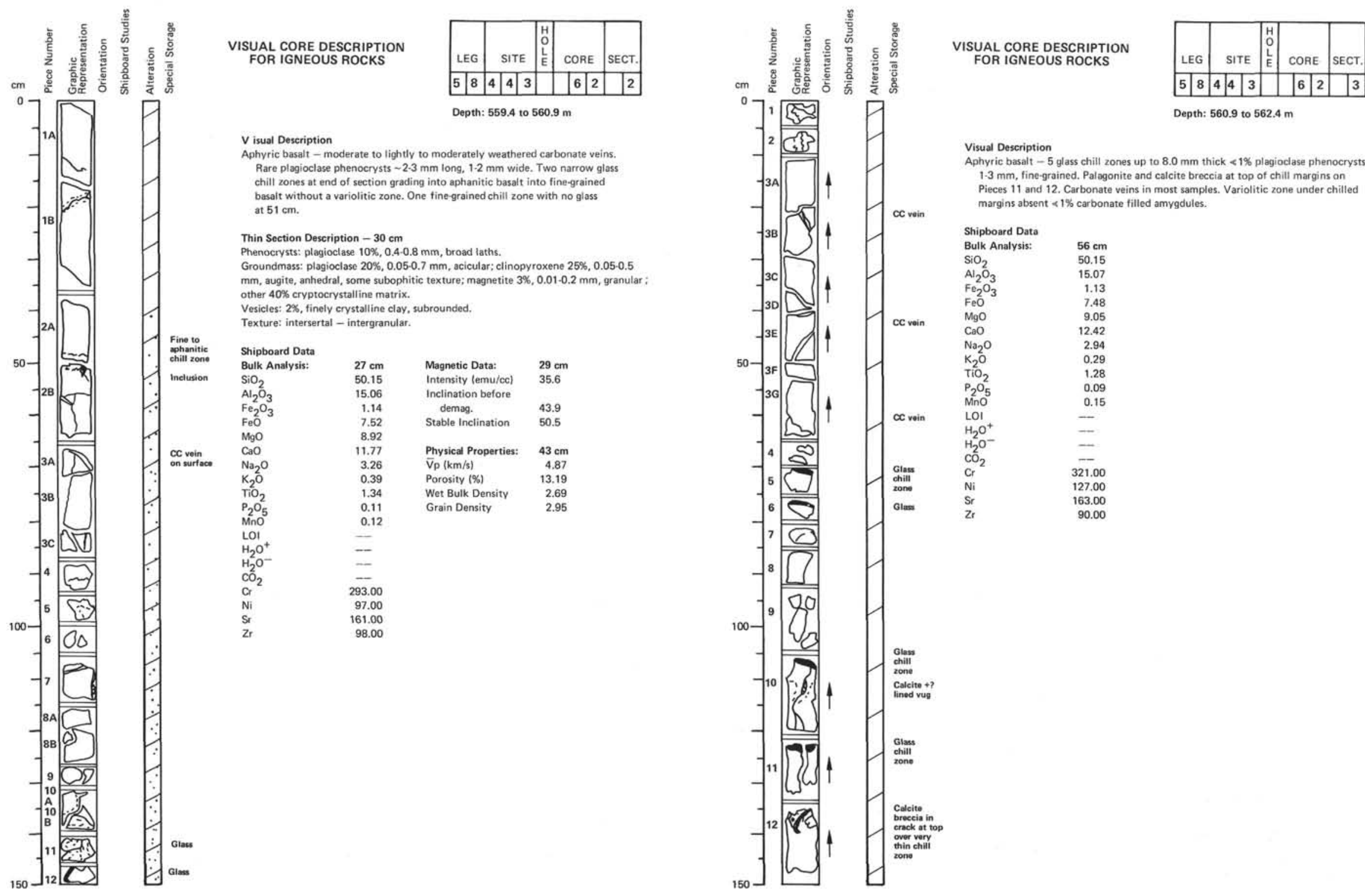
\begin{tabular}{|l|l|l|l|l|l|l|l|}
\hline 5 & 8 & 4 & 4 & 3 & 3 & $\mid 6$ & 2 \\
\hline
\end{tabular} Depth: 560.9 to $562.4 \mathrm{~m}$

列 Pieces 11 and 12 . Carbonate veins in most samples. Variolitic zone under chilled

\begin{tabular}{|c|c|}
\hline Bulk Analysis: & $56 \mathrm{~cm}$ \\
\hline & 50.15 \\
\hline $\mathrm{Al}_{2} \mathrm{O}_{3}$ & 15.07 \\
\hline $\begin{array}{l}\mathrm{Fe}_{2}^{2} \mathrm{O}_{3} \\
\mathrm{FeO}^{2}\end{array}$ & 1.13 \\
\hline $\begin{array}{l}\mathrm{FeO}_{\mathrm{eO}} \\
\mathrm{MgO}\end{array}$ & 7.48 \\
\hline $\begin{array}{l}\mathrm{MgO} \\
\mathrm{C}_{30} \mathrm{O}\end{array}$ & 9.05 \\
\hline $\begin{array}{l}\mathrm{CaO} \\
\mathrm{Na}_{2} \mathrm{O}\end{array}$ & 12.42 \\
\hline $\begin{array}{l}\mathrm{Na}_{2} \mathrm{O} \\
\mathrm{K}_{2} \mathrm{O}\end{array}$ & 2.94 \\
\hline $\mathrm{TiO}_{2}$ & $\begin{array}{l}0.29 \\
1.28\end{array}$ \\
\hline $\begin{array}{l}\mathrm{P}_{2} \mathrm{O}_{5}^{2} \\
\mathrm{MnO}\end{array}$ & 0.09 \\
\hline $\begin{array}{l}\mathrm{MnO} \\
\mathrm{LO}\end{array}$ & 0.15 \\
\hline${ }_{\mathrm{H}}^{\mathrm{LOI} \mathrm{O}^{+}}$ & $\overline{-}$ \\
\hline $\mathrm{H}_{2} \mathrm{O}^{-}$ & $=$ \\
\hline $\mathrm{CO}_{2}$ & -- \\
\hline Cr & 321.00 \\
\hline $\mathrm{Ni}$ & 127.00 \\
\hline Sr & 163.00 \\
\hline & 90.00 \\
\hline
\end{tabular}



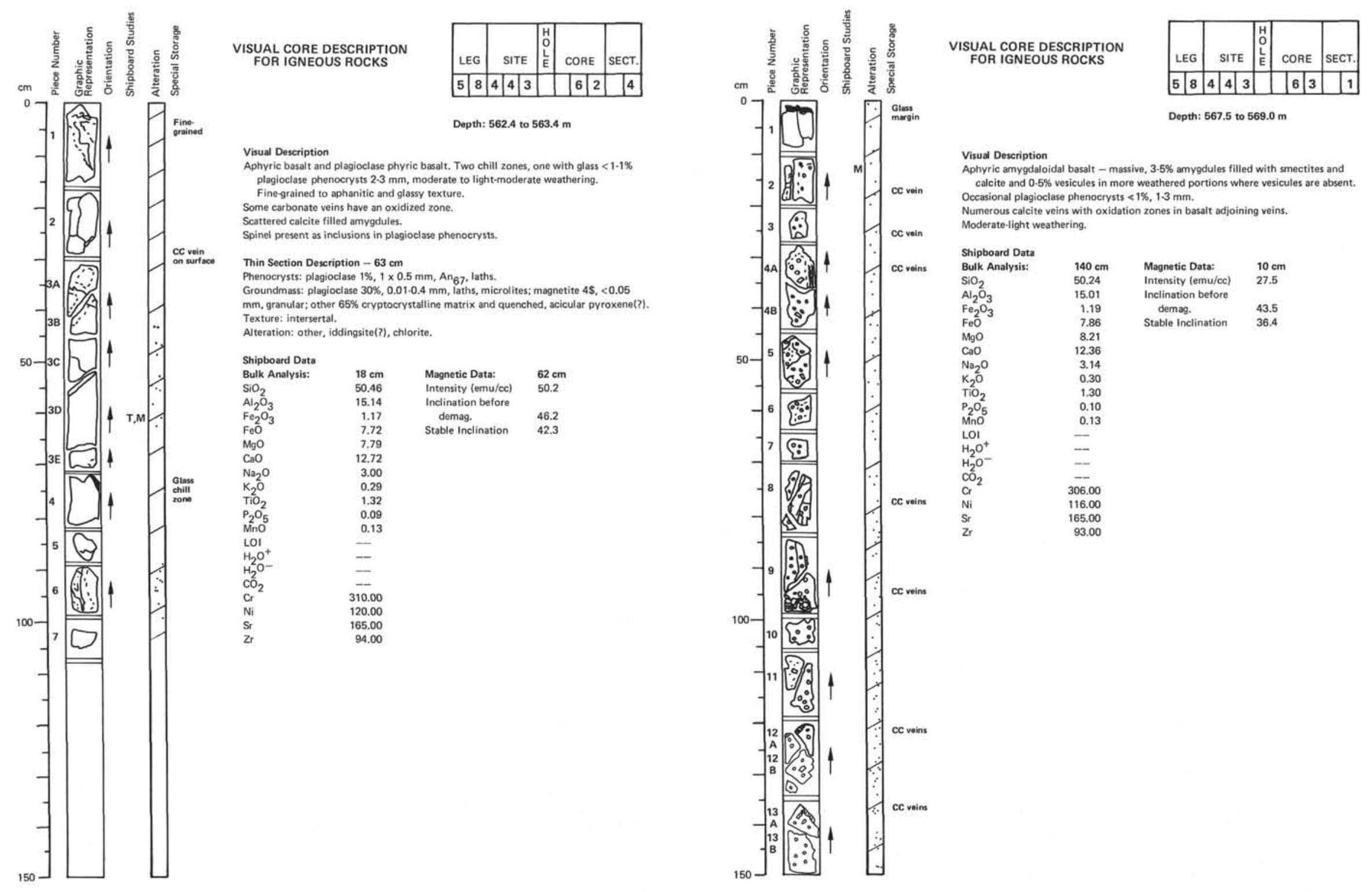


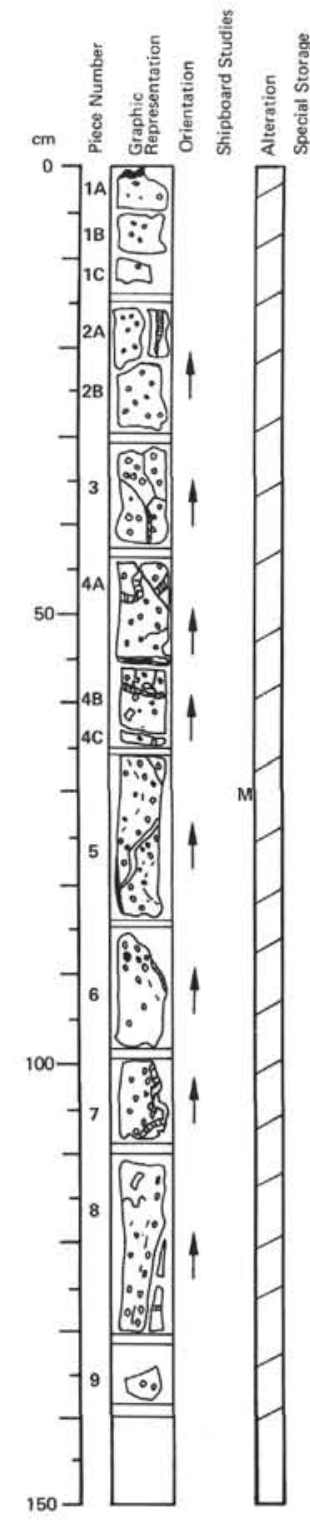

VISUAL CORE DESCRIPTION FOR IGNEOUS ROCKS

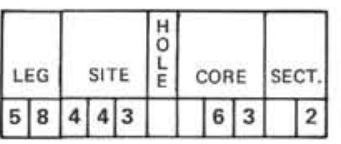

Visual Description

A to $3 \times 2 \mathrm{~mm}$ fine-grained, $3.7 \%$ amygdules filled with calcite and smectites. Numerous colcite veins, oxidized zones in adjacent basalt. Moderately weathered. as much as $7 \%$ medium vesicles $(1.3 \mathrm{~mm})$.

Thin Section Description $-60 \mathrm{~cm}$

taths, of ten as microlites; clinopyroxene $25 \%$, acicular, Vesicles: $5 \%, 0.1-0.8 \mathrm{~mm}$ calcite, subrounded.

.

Shipboard Data

Magnetic Data: Intensity (emu/cc) $\quad 50.8$ Inclination before 47.6
47.1

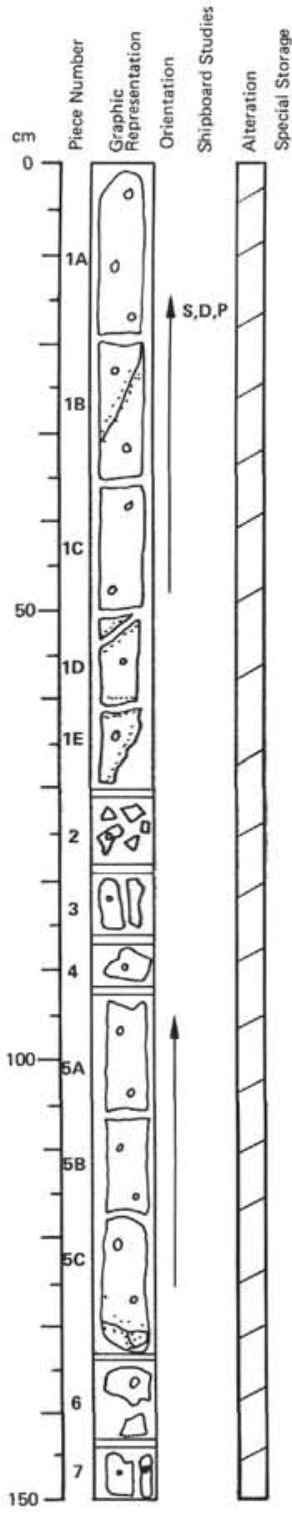

VISUAL CORE DESCRIPTION FOR IGNEOUS ROCKS

\begin{tabular}{|c|c|c|c|c|}
\hline LEG & SITE & $\begin{array}{l}\mathrm{H} \\
\mathrm{H} \\
\mathrm{L}\end{array}$ & CORE & SECT \\
\hline \begin{tabular}{|l|l}
5 & 8 \\
\end{tabular} & \begin{tabular}{|l|l|}
4 & 4 \\
\end{tabular} & & \begin{tabular}{|l|}
6 \\
\end{tabular} & 3 \\
\hline
\end{tabular}
Depth: 570.4 to $571.9 \mathrm{~m}$

\section{Visual Description}

at in Section 2 (Core 63).

作, illed with calcite. Yellowish color associatod with oxidation.

Thin Section Description - $59 \mathrm{~cm}$

(a) $30 \%, 0.1-0.8 \mathrm{~mm}$, anhedral; magnetife $2 \% ; 0.01-0.2 \mathrm{~mm}$, granular.

Vesicles: $5 \%, 0.1 \cdot 1.5 \mathrm{~mm}$, calcite, subrounded.

re: intersertal - intergranul

.

Shipboard Data

Bulk Analysis: $\quad 116 \mathrm{~cm}$

$\mathrm{SiO}_{2} \quad 49.97$

$\begin{array}{ll}\mathrm{Fe}_{2} \mathrm{O}_{3} & 1.14 \\ \mathrm{FeO}_{3} & 7.52\end{array}$

$\begin{array}{ll}\mathrm{FeO} & 7.52 \\ \mathrm{MgO} & 8.74\end{array}$

$\begin{array}{lr}\mathrm{CaO} & 12.70 \\ \mathrm{Na}_{2} \mathrm{O} & 3.08\end{array}$

$\begin{array}{ll}\mathrm{Na}_{2} \mathrm{O} & 3.08 \\ \mathrm{~K}_{2} \mathrm{O} & 0.28\end{array}$

$\mathrm{TiO}_{2} \quad 1.27$

Mno $\quad 0.12$

$\mathrm{LOI}_{\mathrm{H}_{2} \mathrm{O}^{+}}=$

$\begin{array}{ll}\mathrm{H}_{2} \mathrm{O}^{-} & - \\ \mathrm{CO}_{2} & -\end{array}$

$\begin{array}{ll}\mathrm{Cr} & 307.00 \\ \mathrm{Ni} & 18000\end{array}$

$\begin{array}{lr}\text { St } & 180.00 \\ \mathrm{Zr} & 16.00 \\ & 91.00\end{array}$

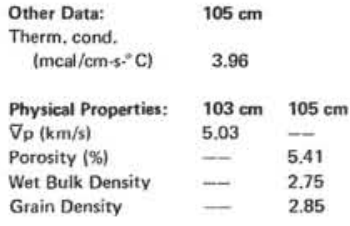




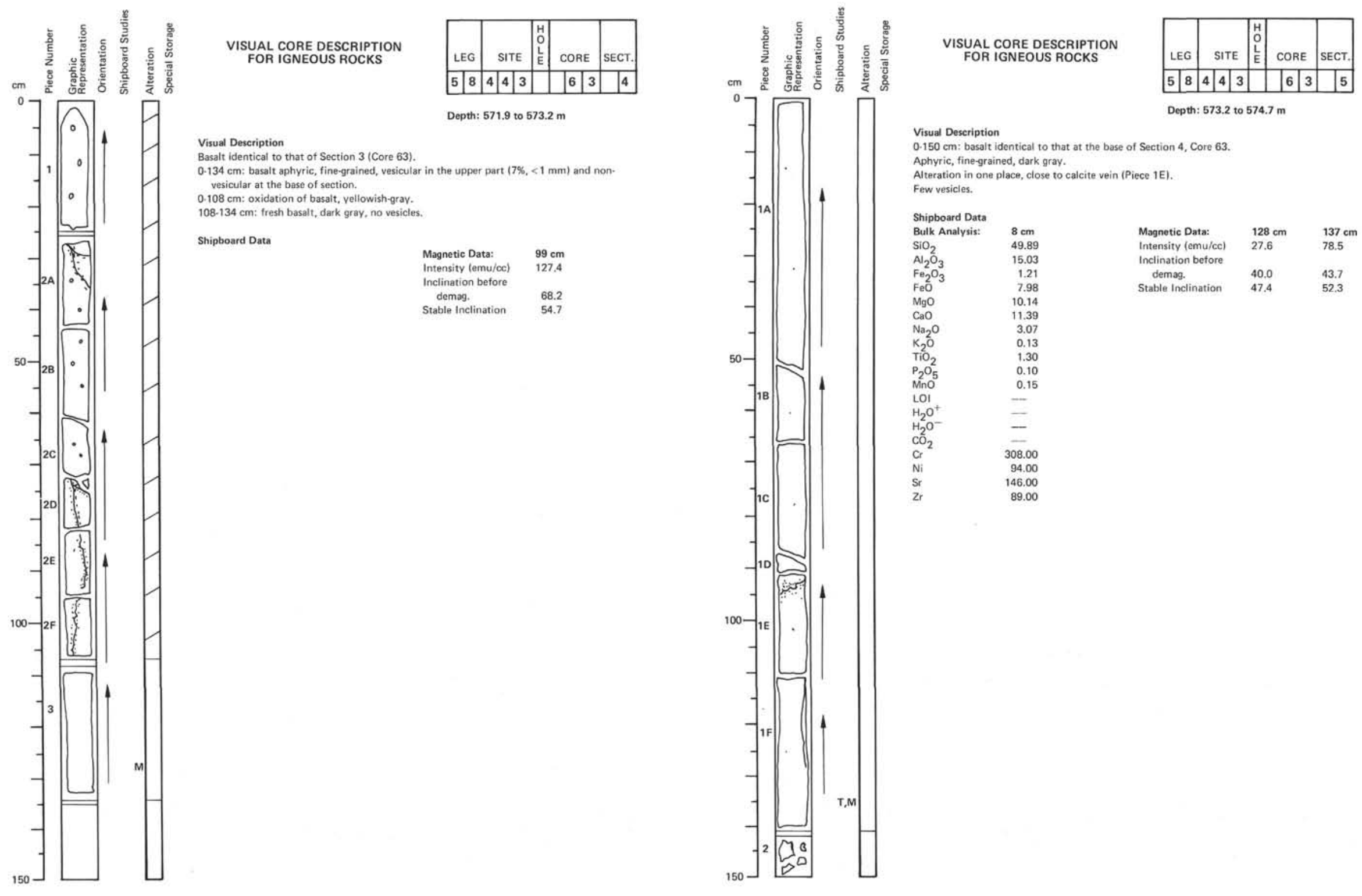



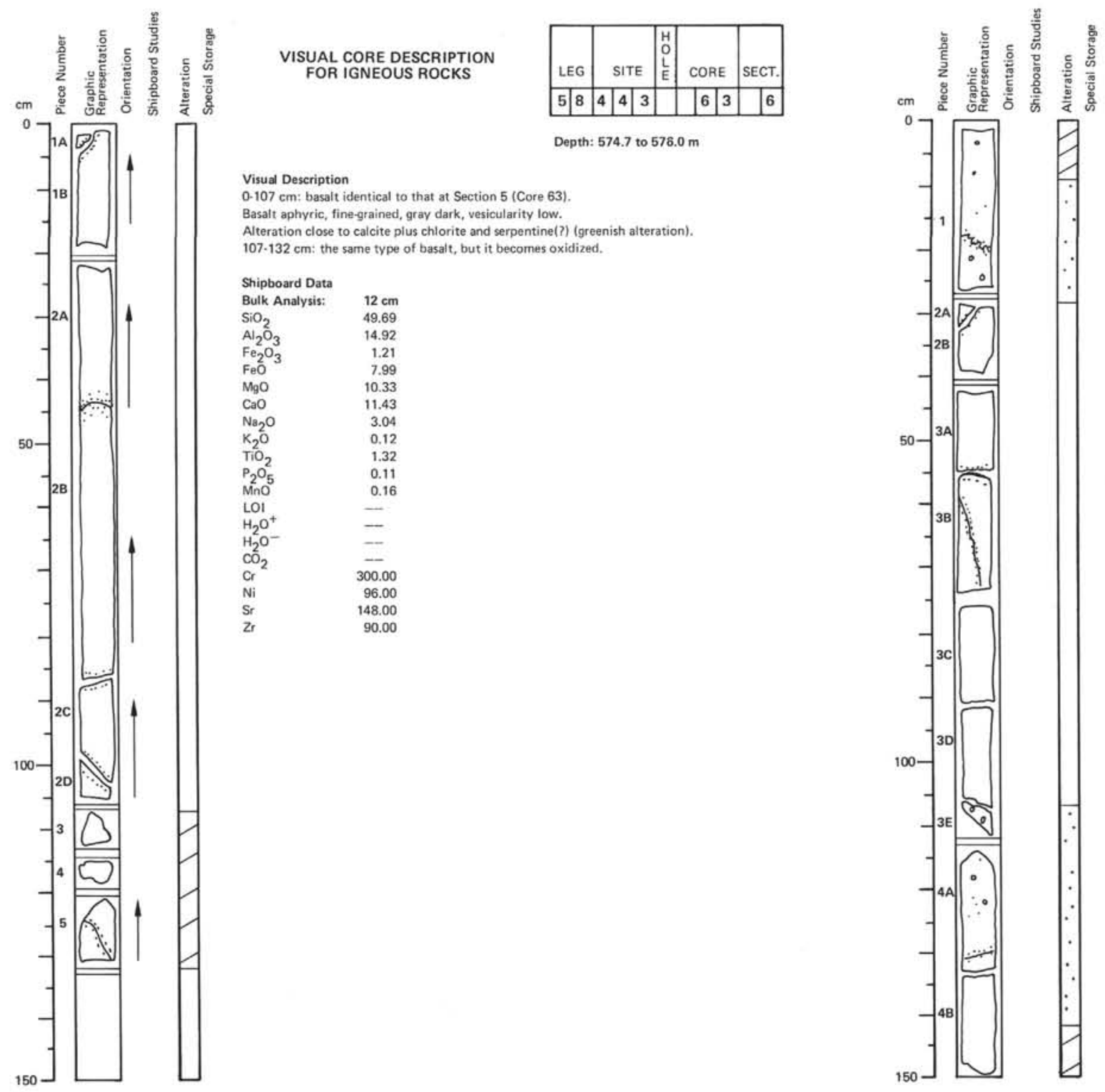

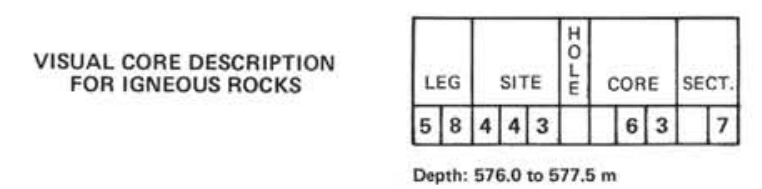

(O)

Basalt apturic, fine-grained, dark gray, partly vesicular $(0.25 \mathrm{~cm}, 3 \%,<1 \mathrm{~mm})$. Vesicles filled with calcite.
$75-150 \mathrm{~cm}$ : similar basalt, but fresh medium-grained, aphyric, dark gray, Plagioclase tath, up to $2 \mathrm{~mm}$.

Alteration close to calcite-zeolite veins. In the same parts oxidation (weathering) occurs. 

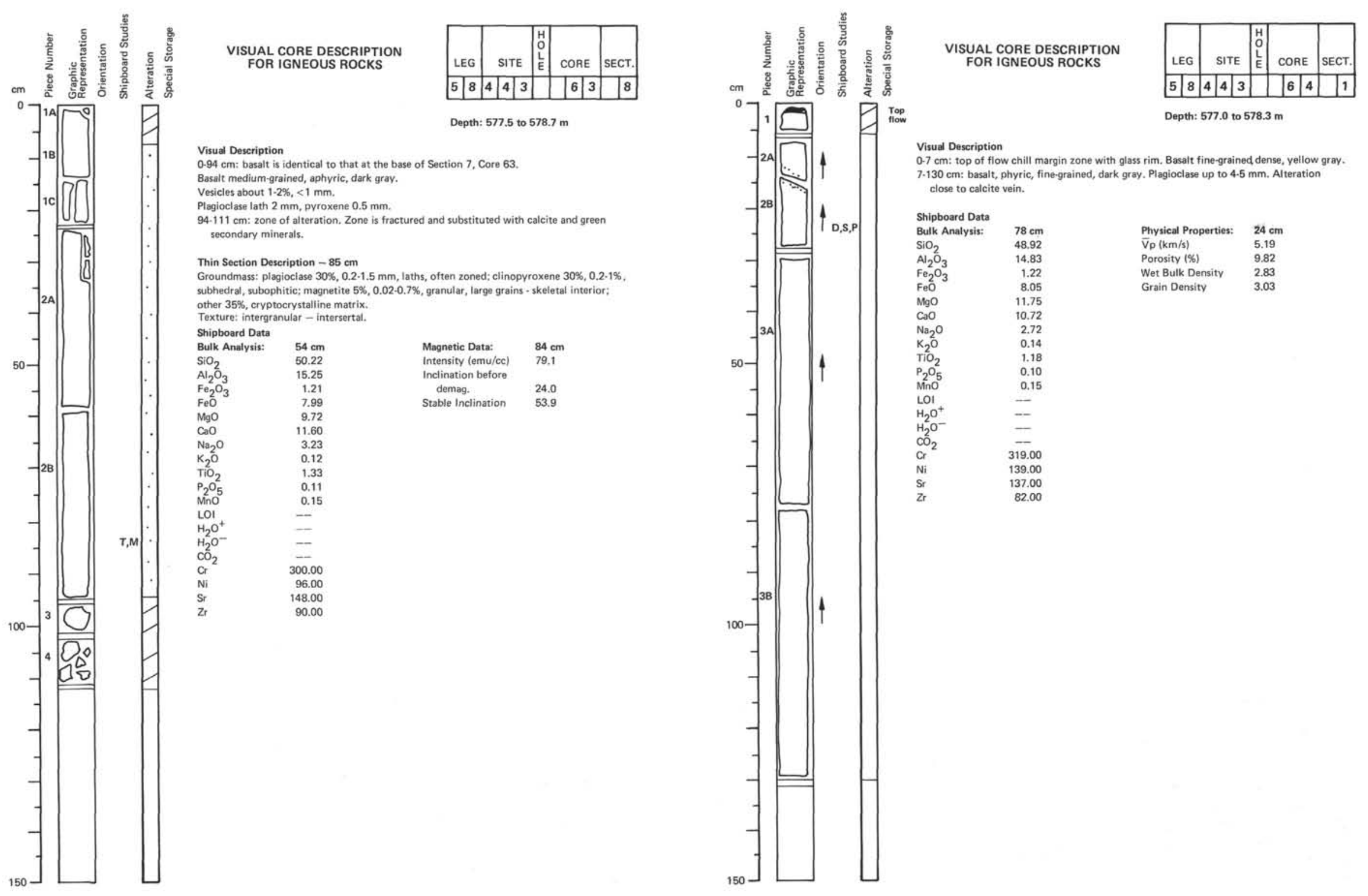

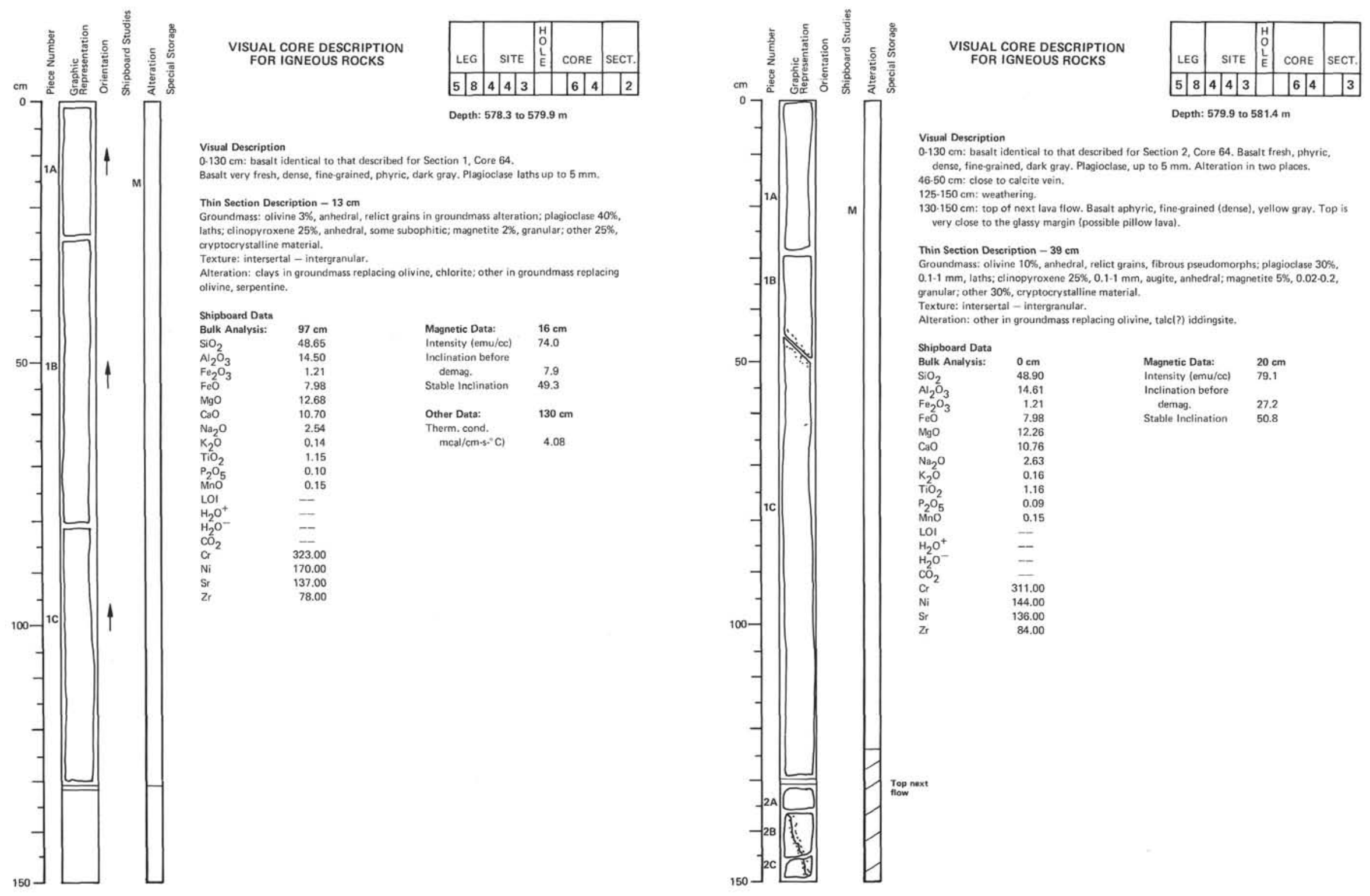


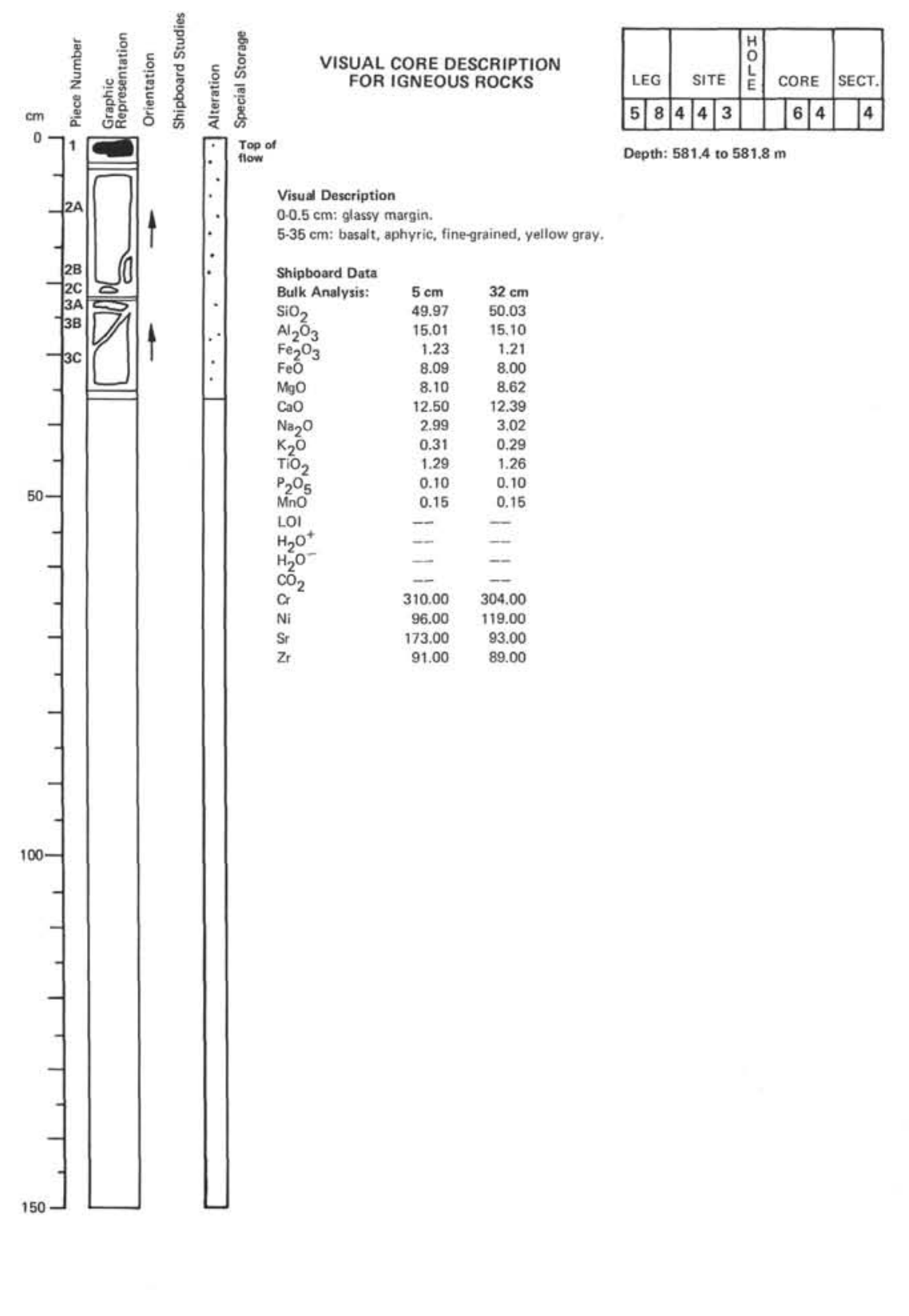




\section{SITE 443}

\section{Site 443}

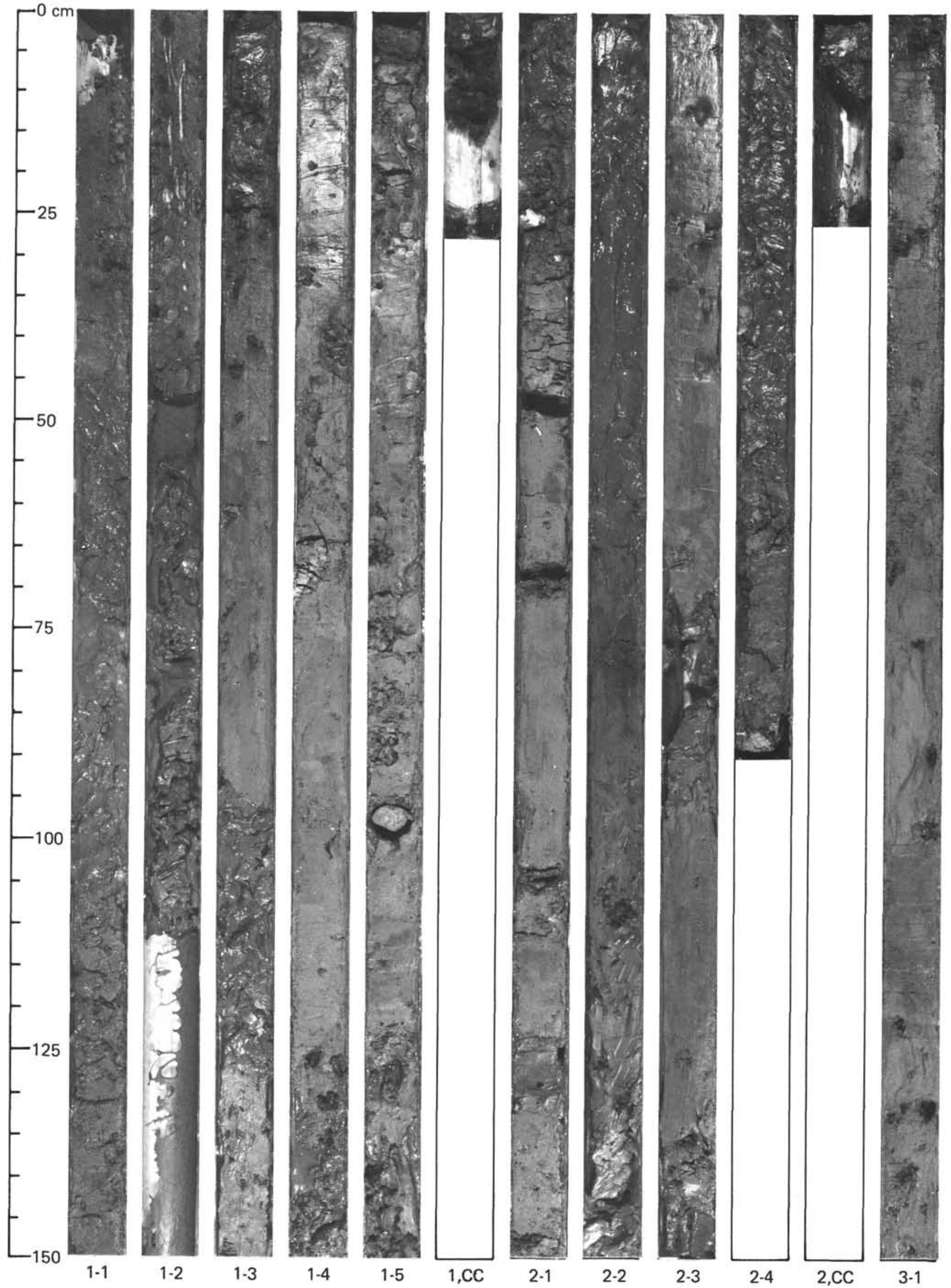


Site 443

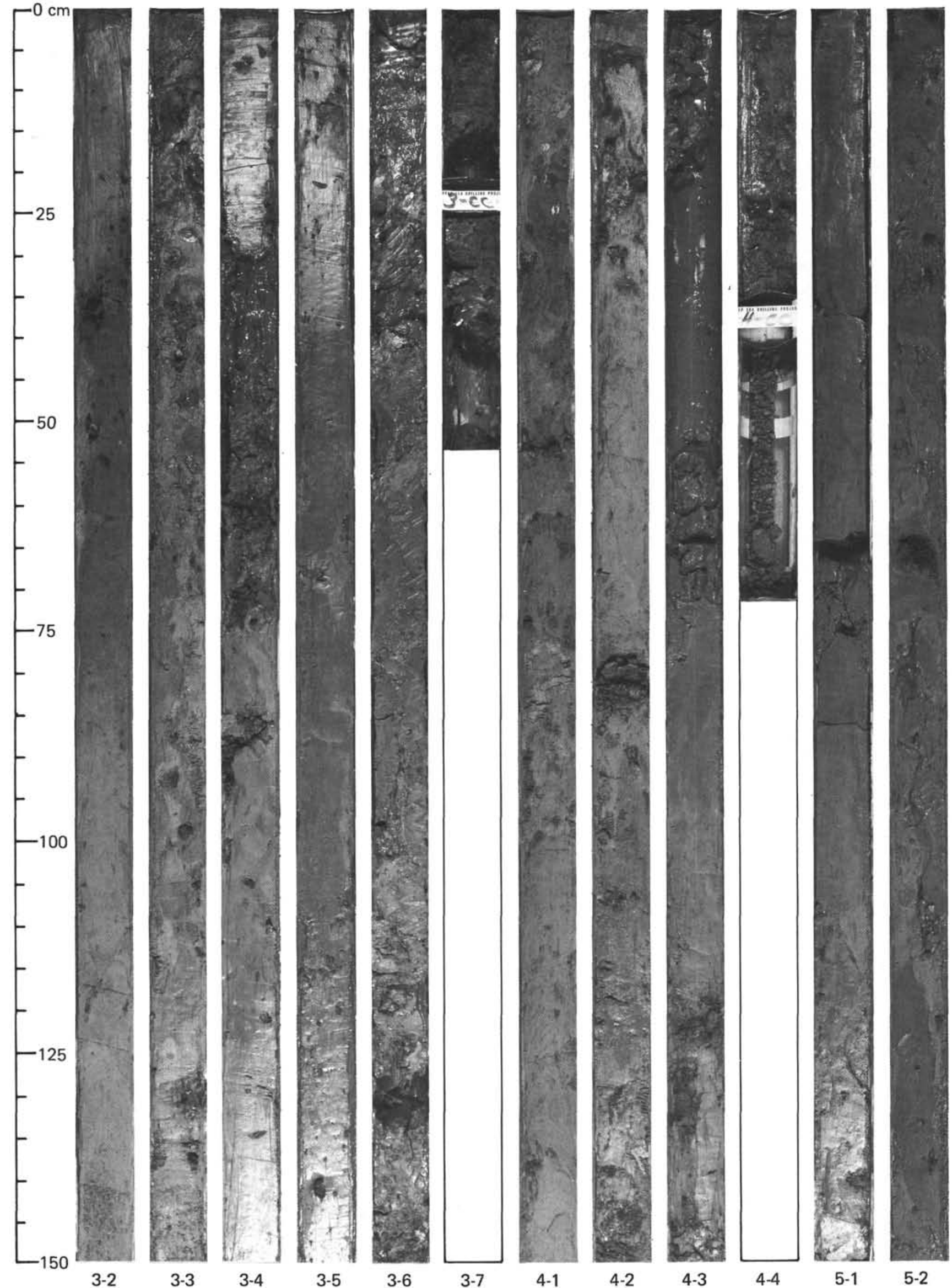




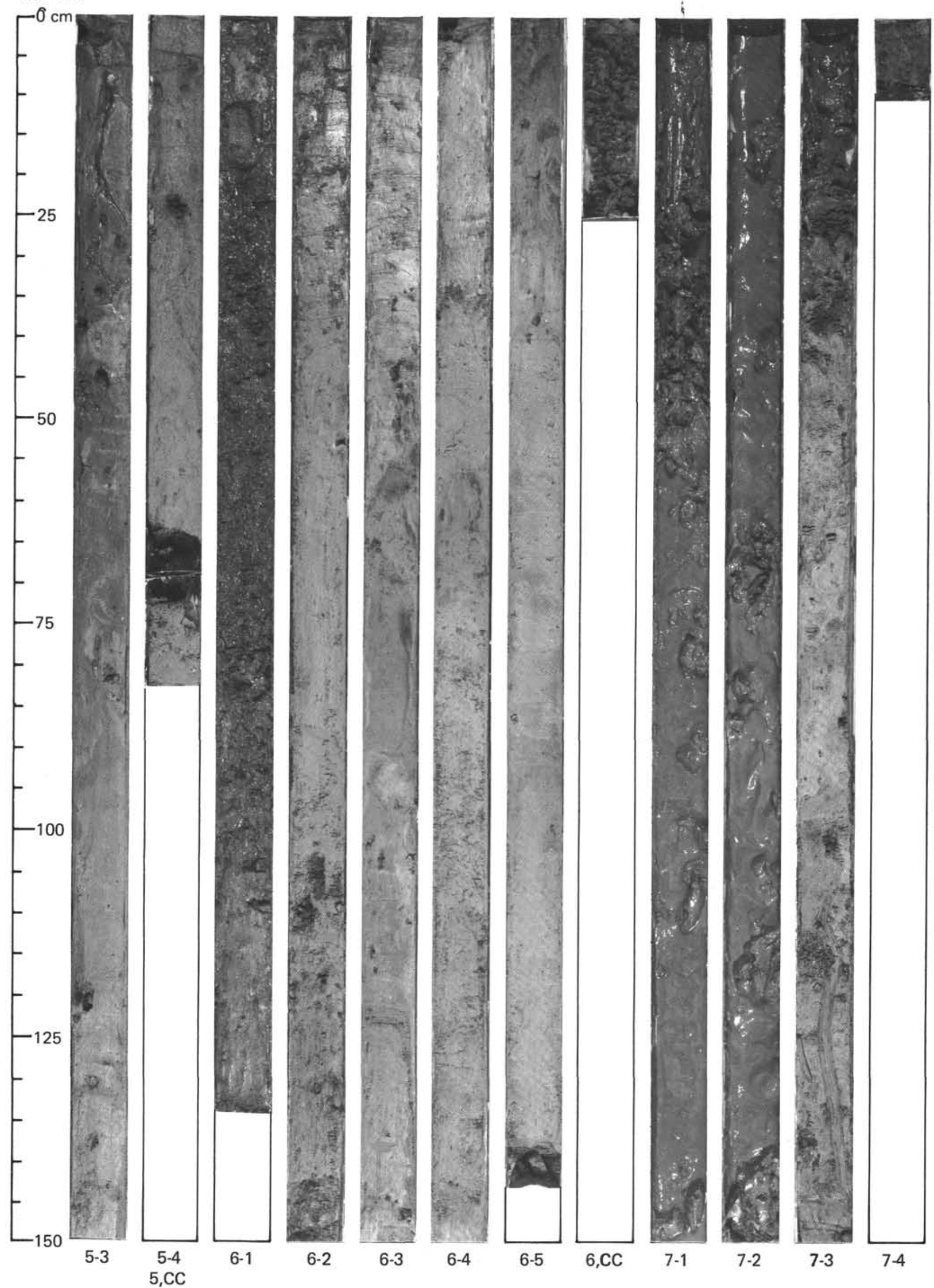


Site 443

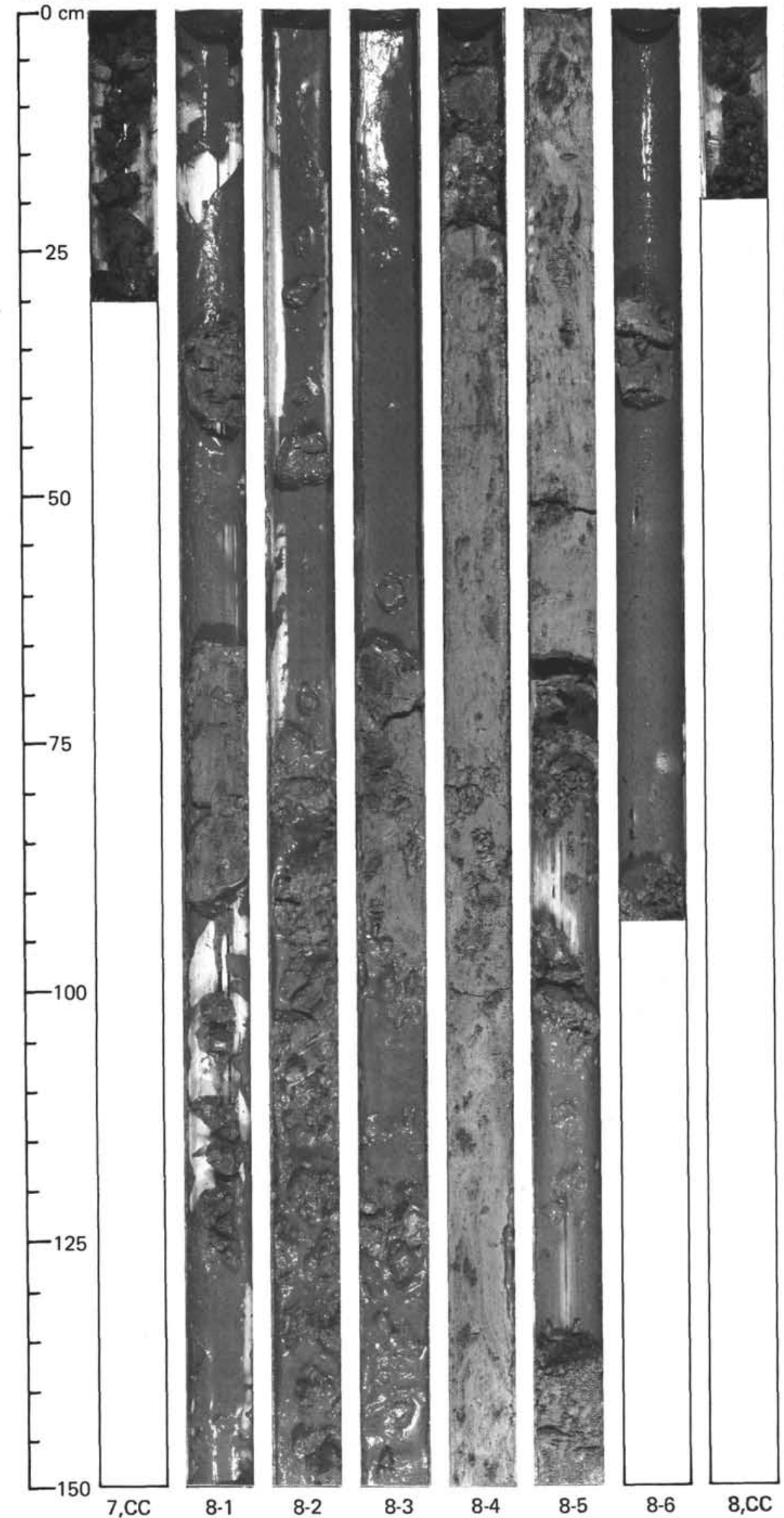

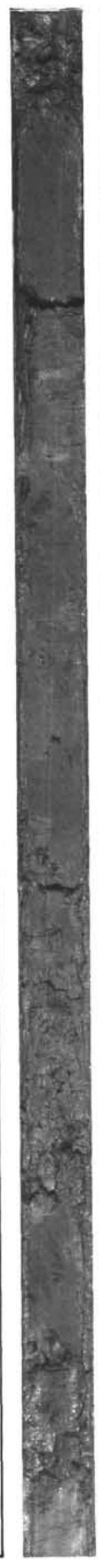

9-1
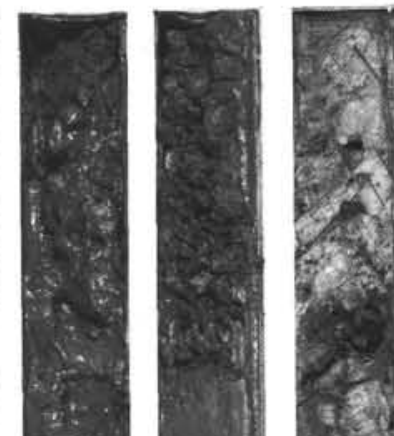

:

i 82

46
8
8

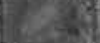

1. 18

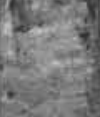

$x^{2} x^{2}=1$

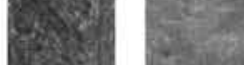

a

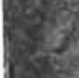

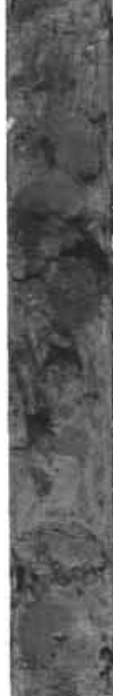

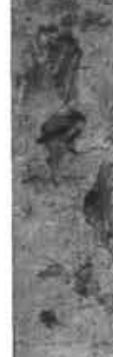
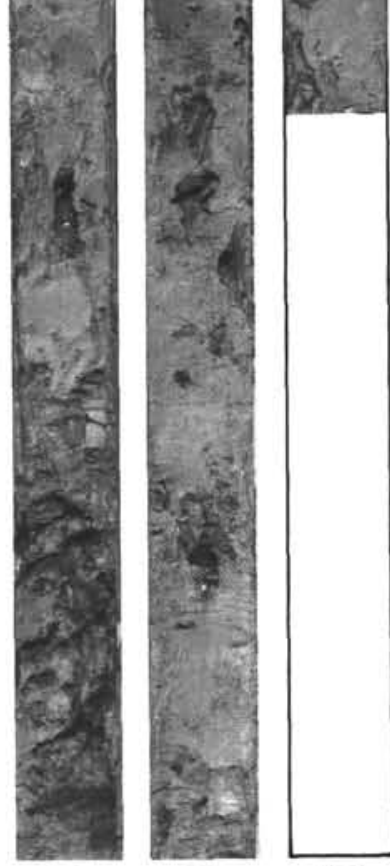

$9-2$

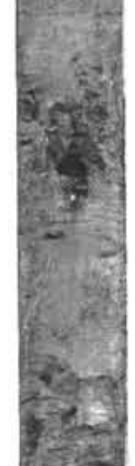

9-3 
Site 443

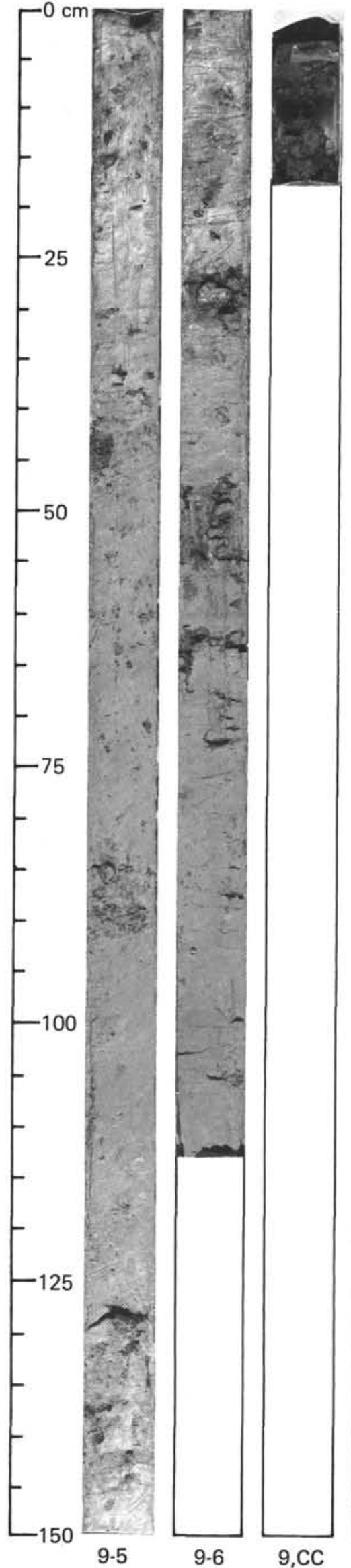

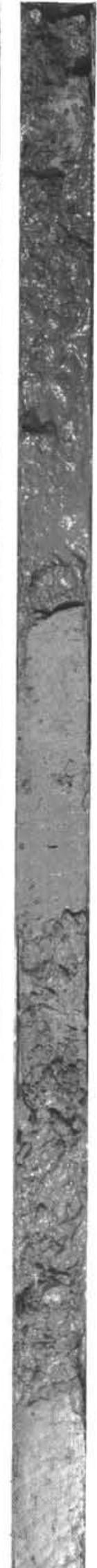
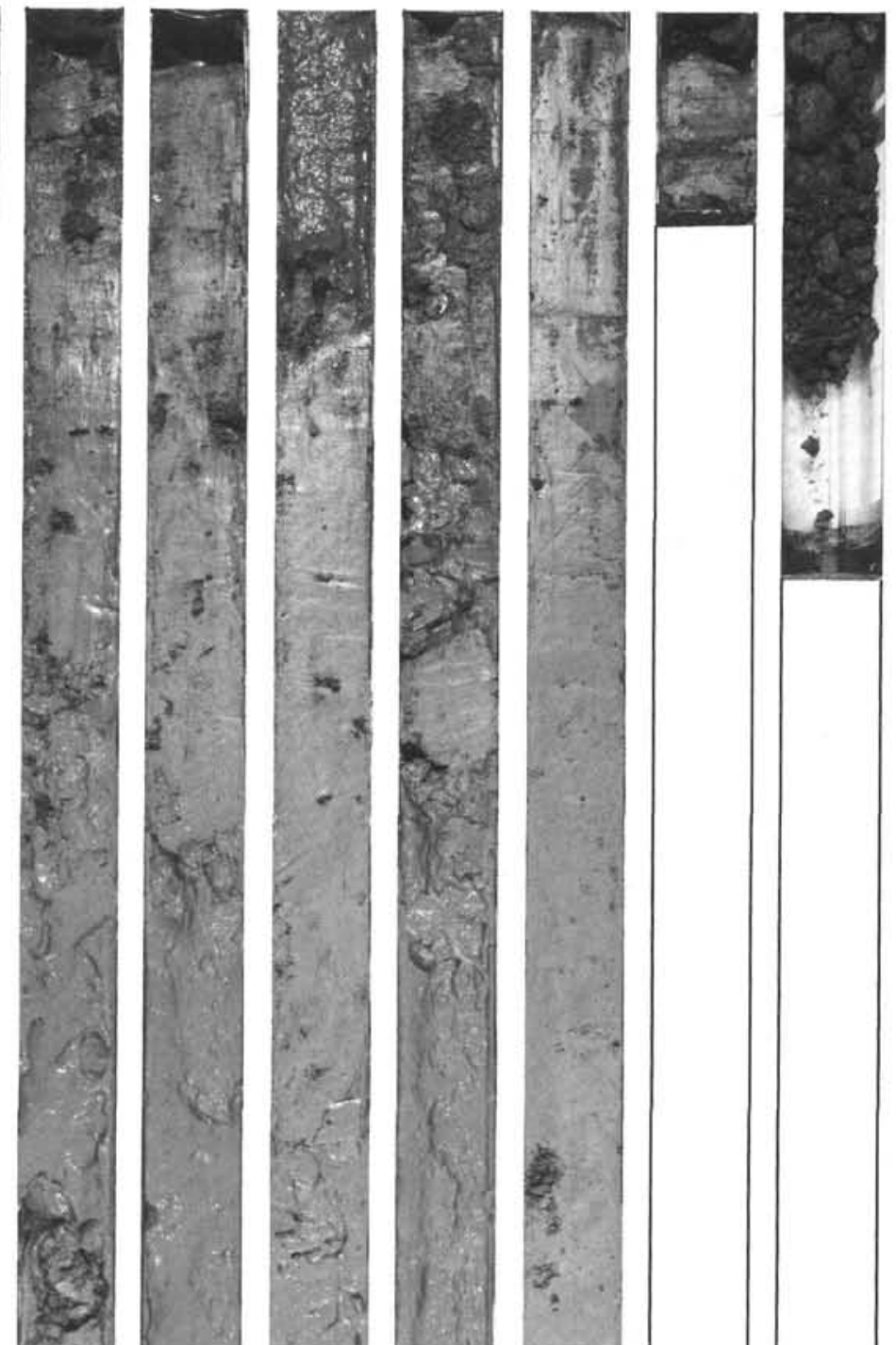

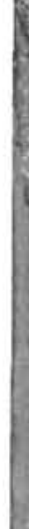
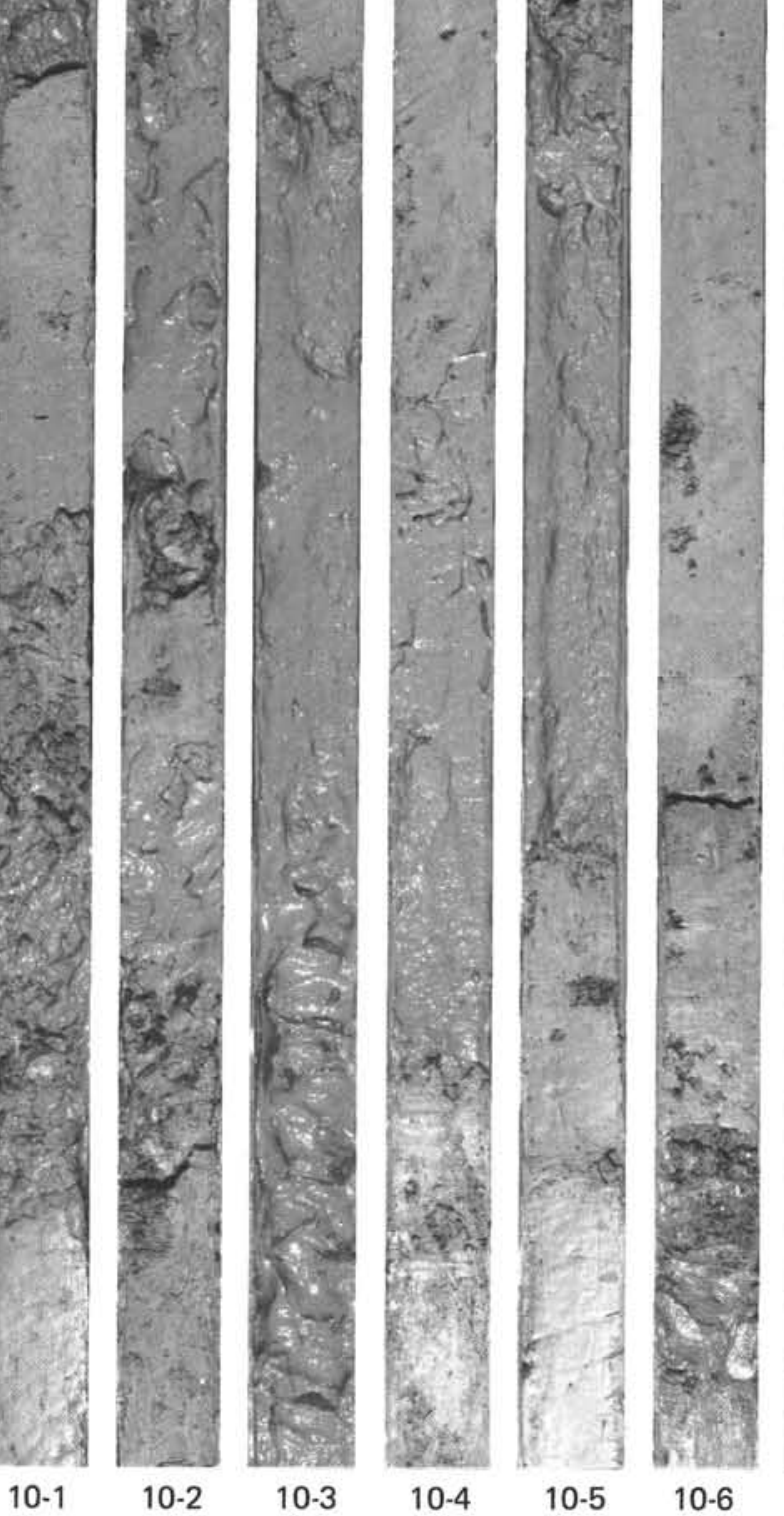

$10-4$ 
Site 443
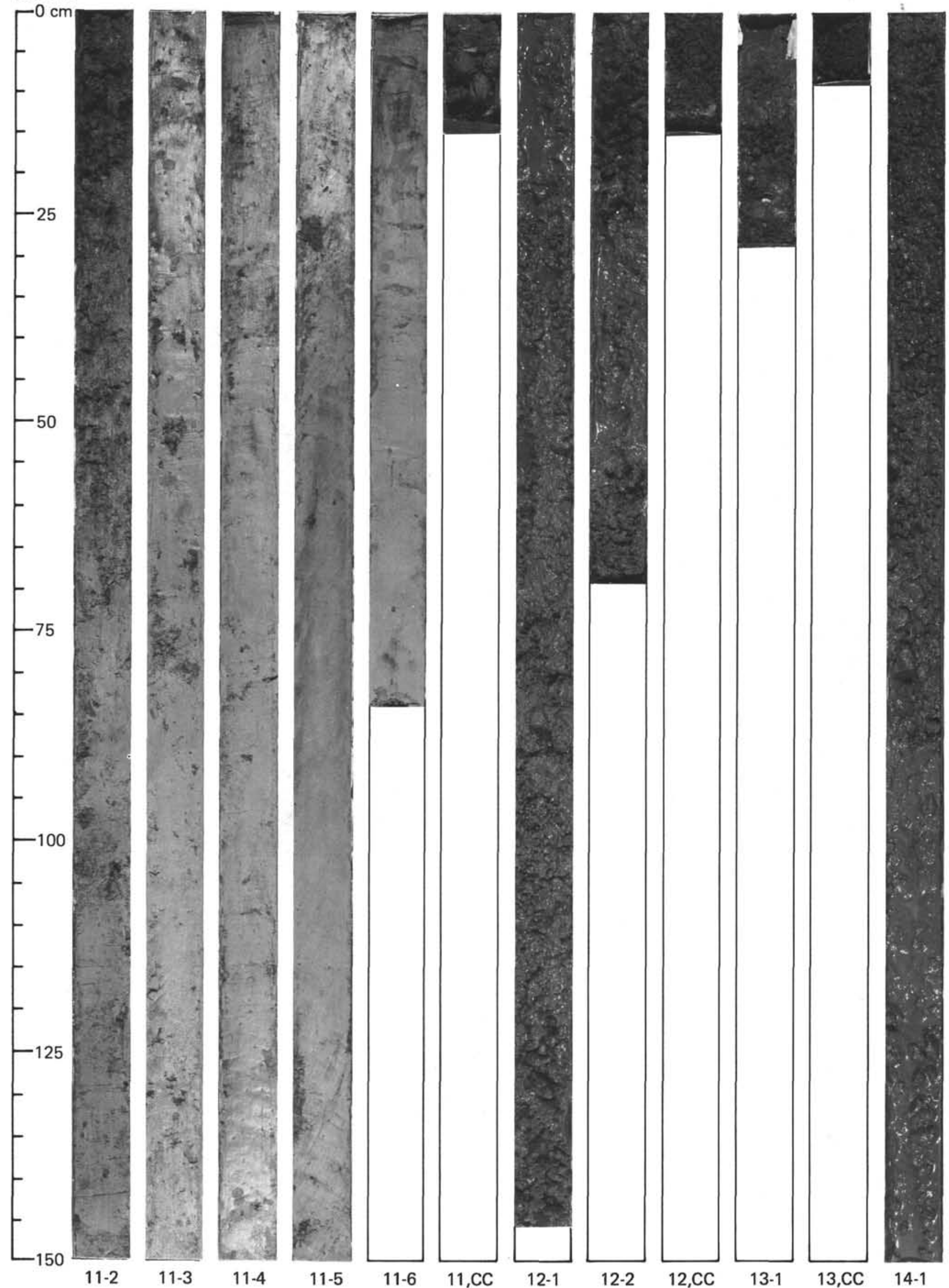

$12, \mathrm{CC}$

13-1 


\section{Site 443}

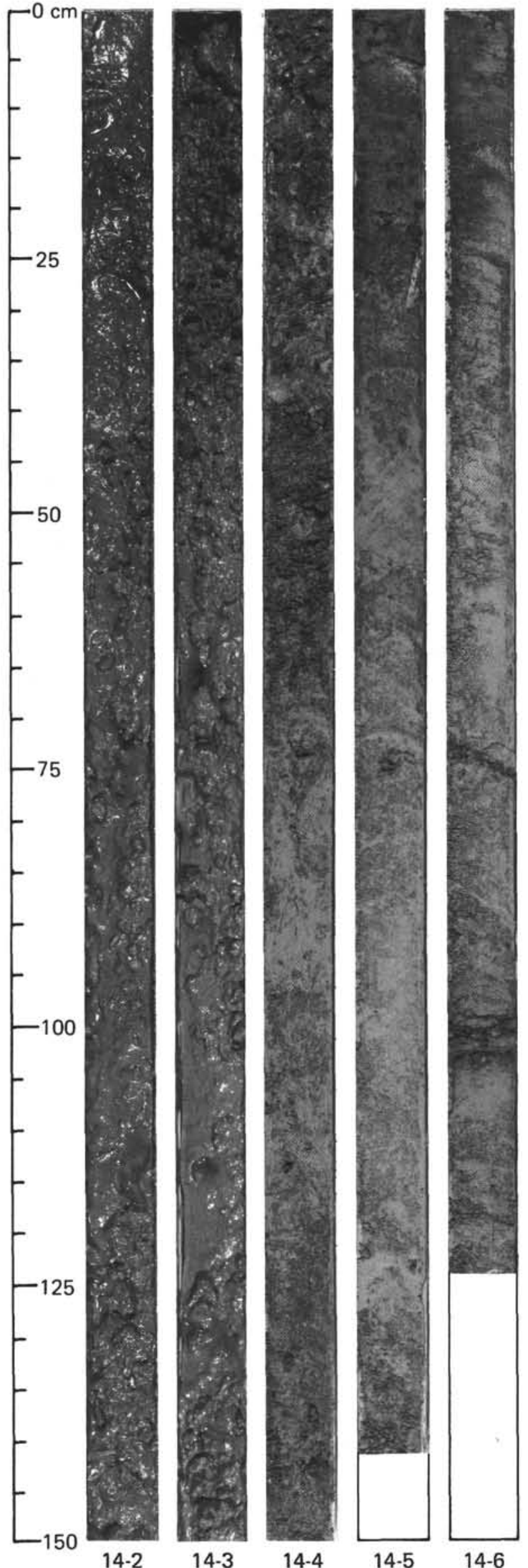

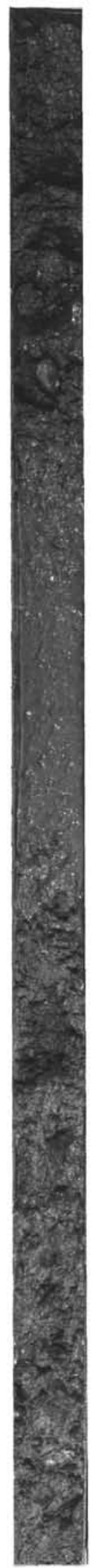

15-1
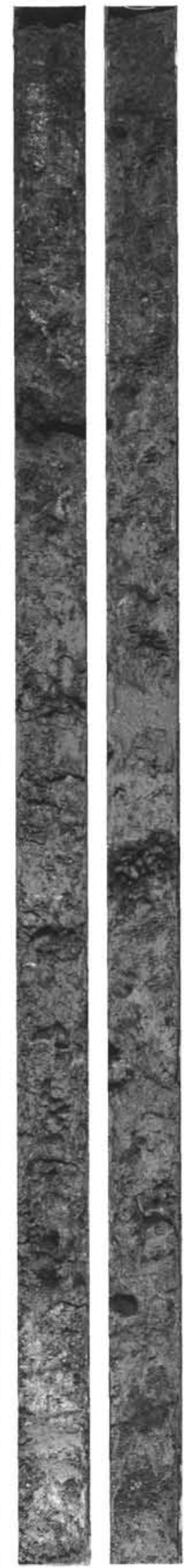

15-3
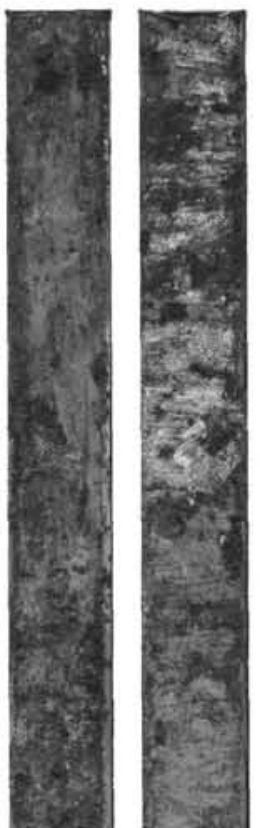

5er

2

sin

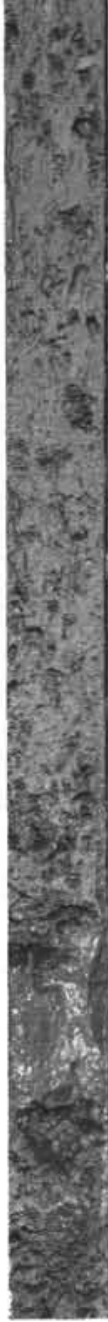

15-4

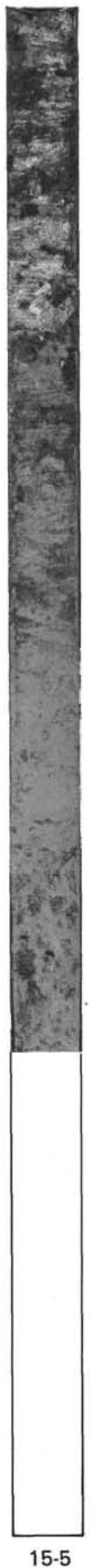

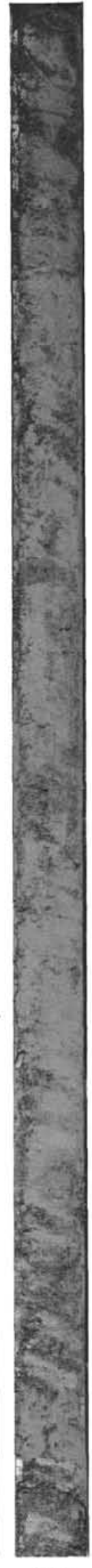
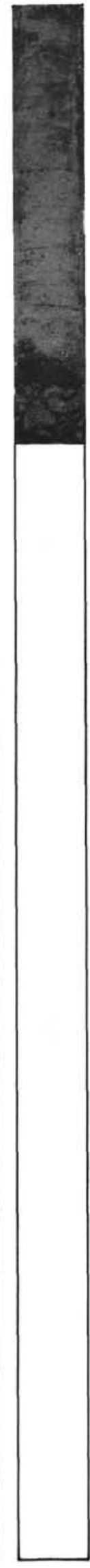

$15-6 \quad 15-7$ 
Site 443

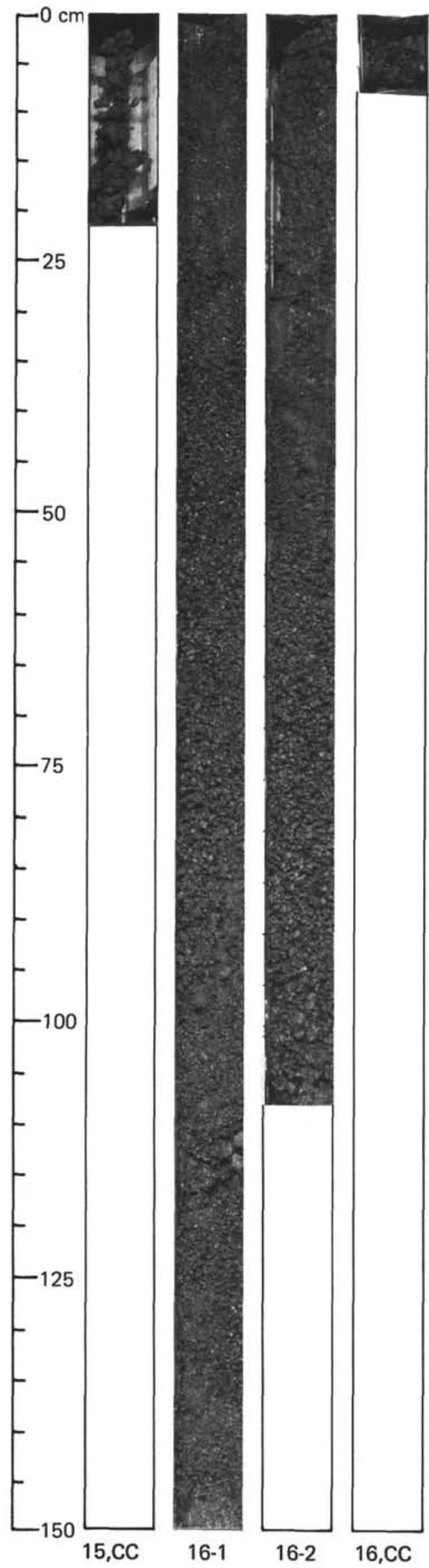

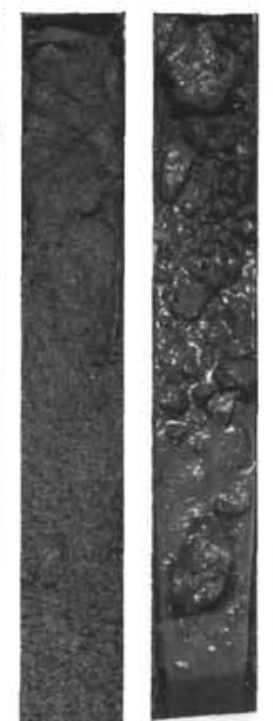
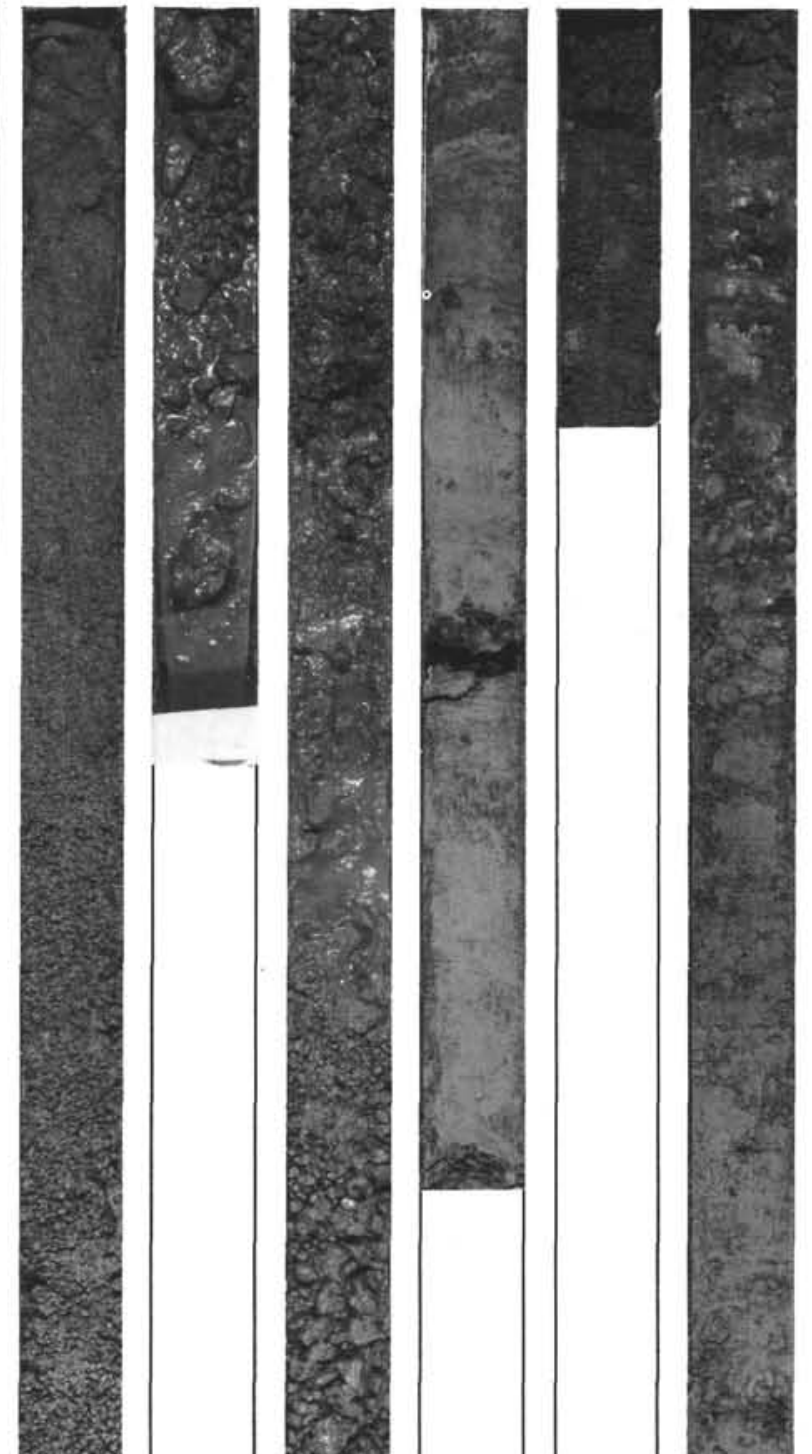

6 sis
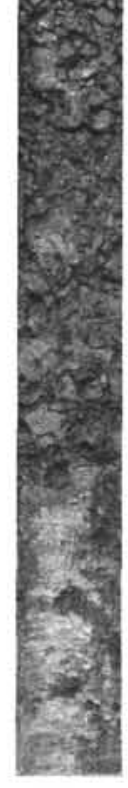

$17-3$

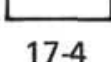

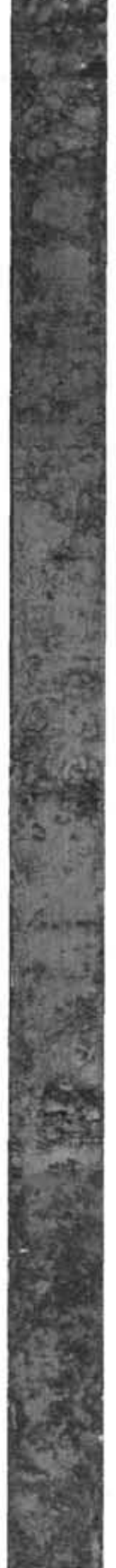

18
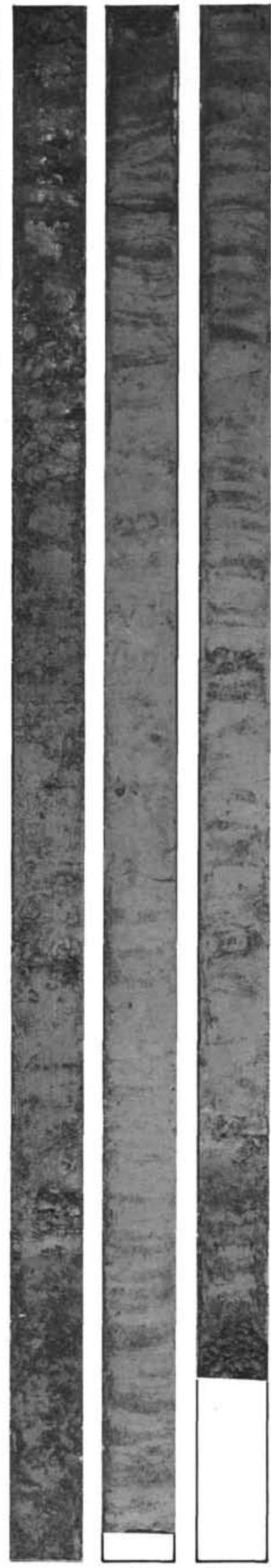

$17 \mathrm{CC}$
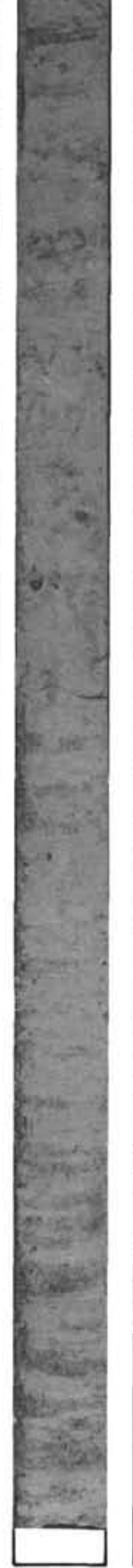

18-2 18-3 
SITE 443

Site 443

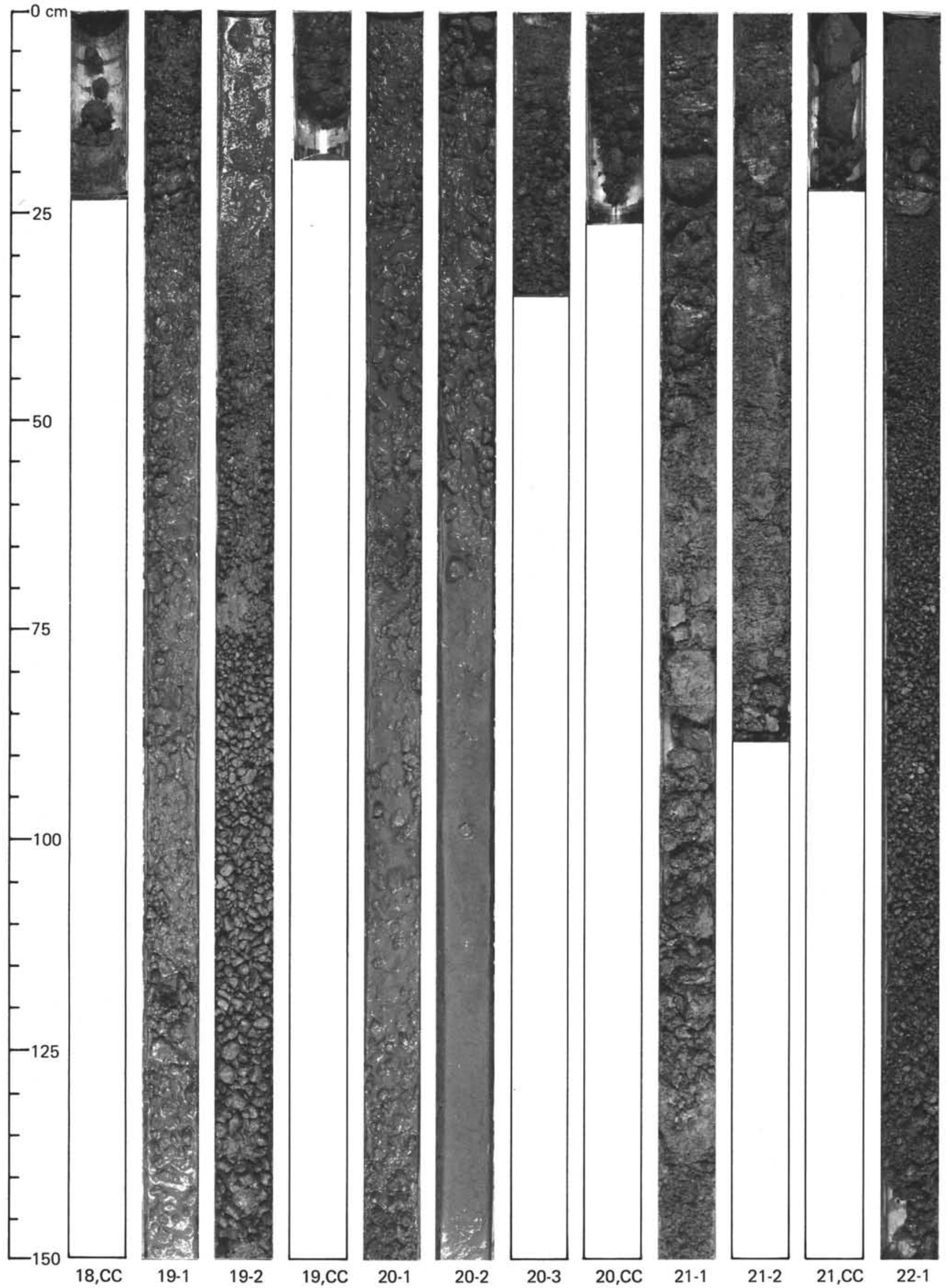


Site 443

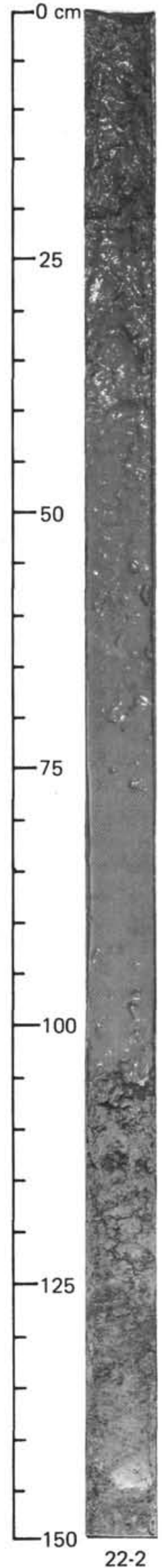

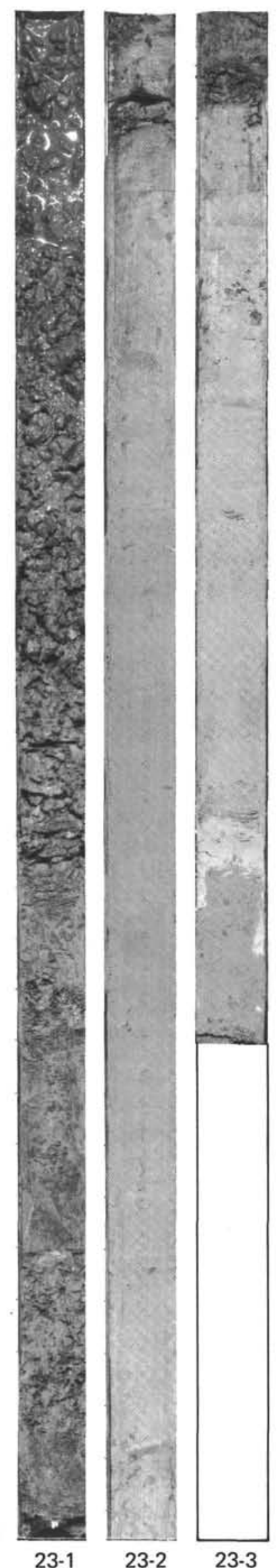
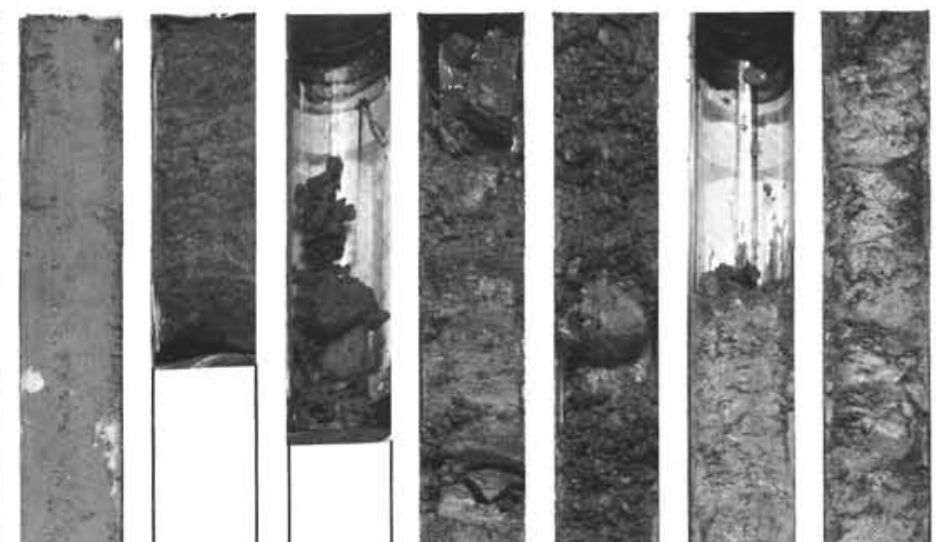

$=2$
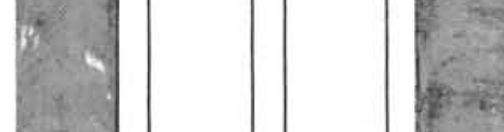

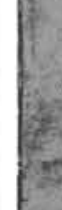

\section{0}

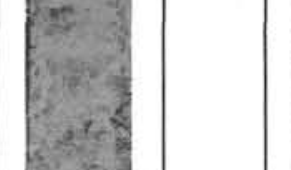$$
\text { 原 }
$$

and $\square$

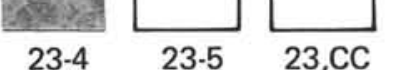

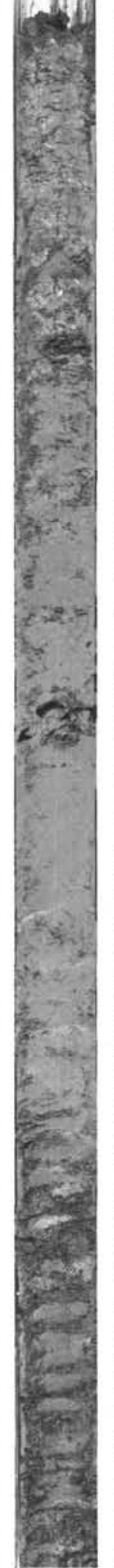

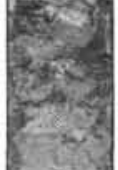

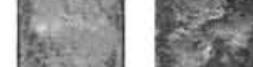

3.

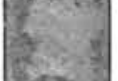

isti

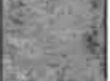

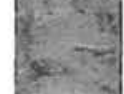

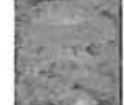

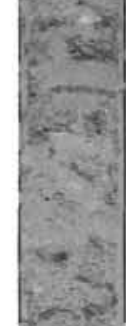

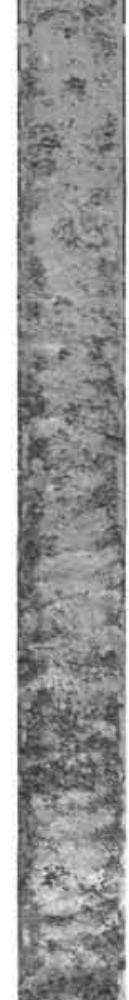

24-4

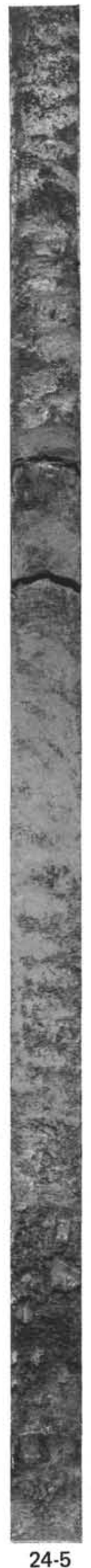



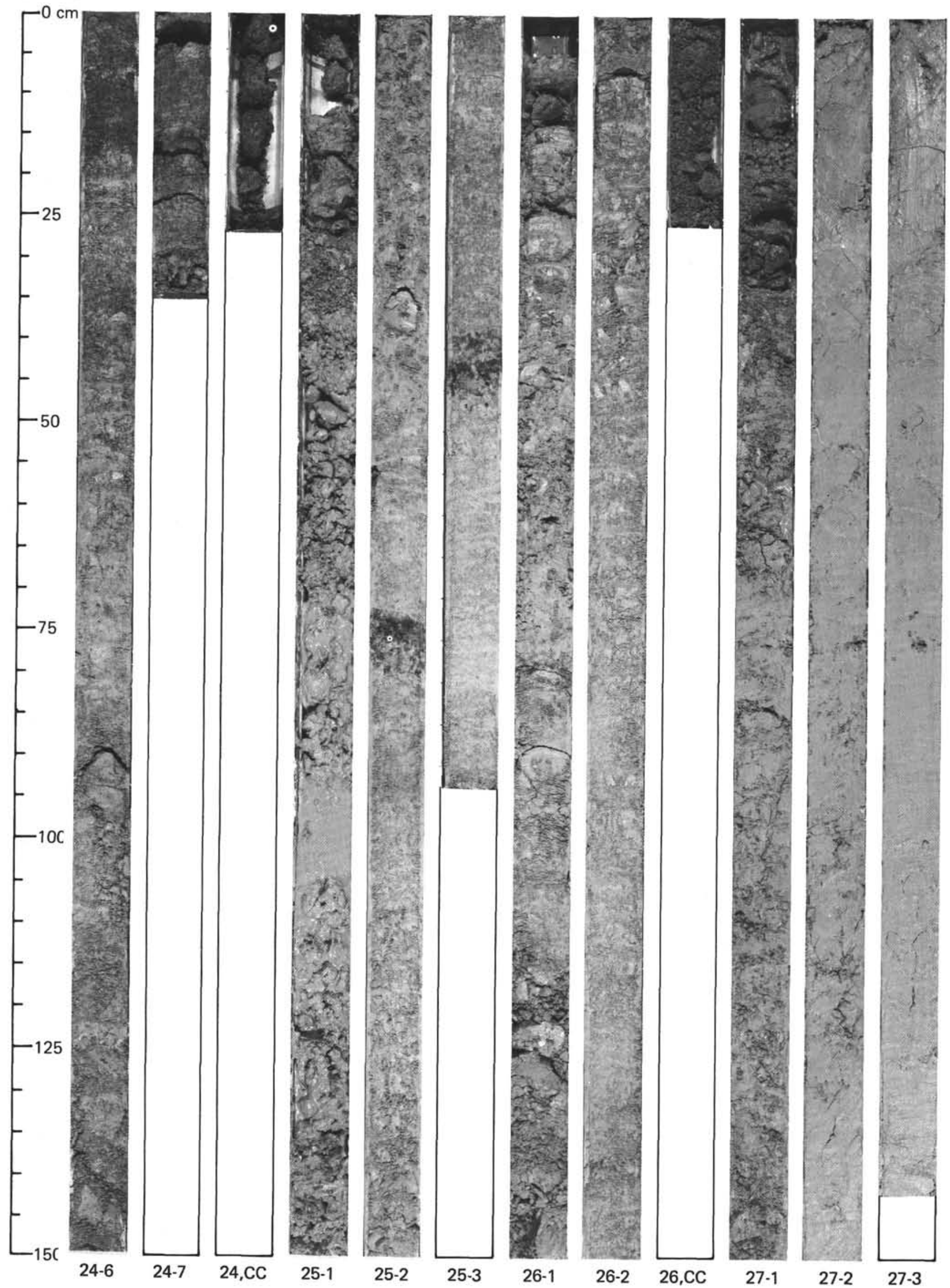


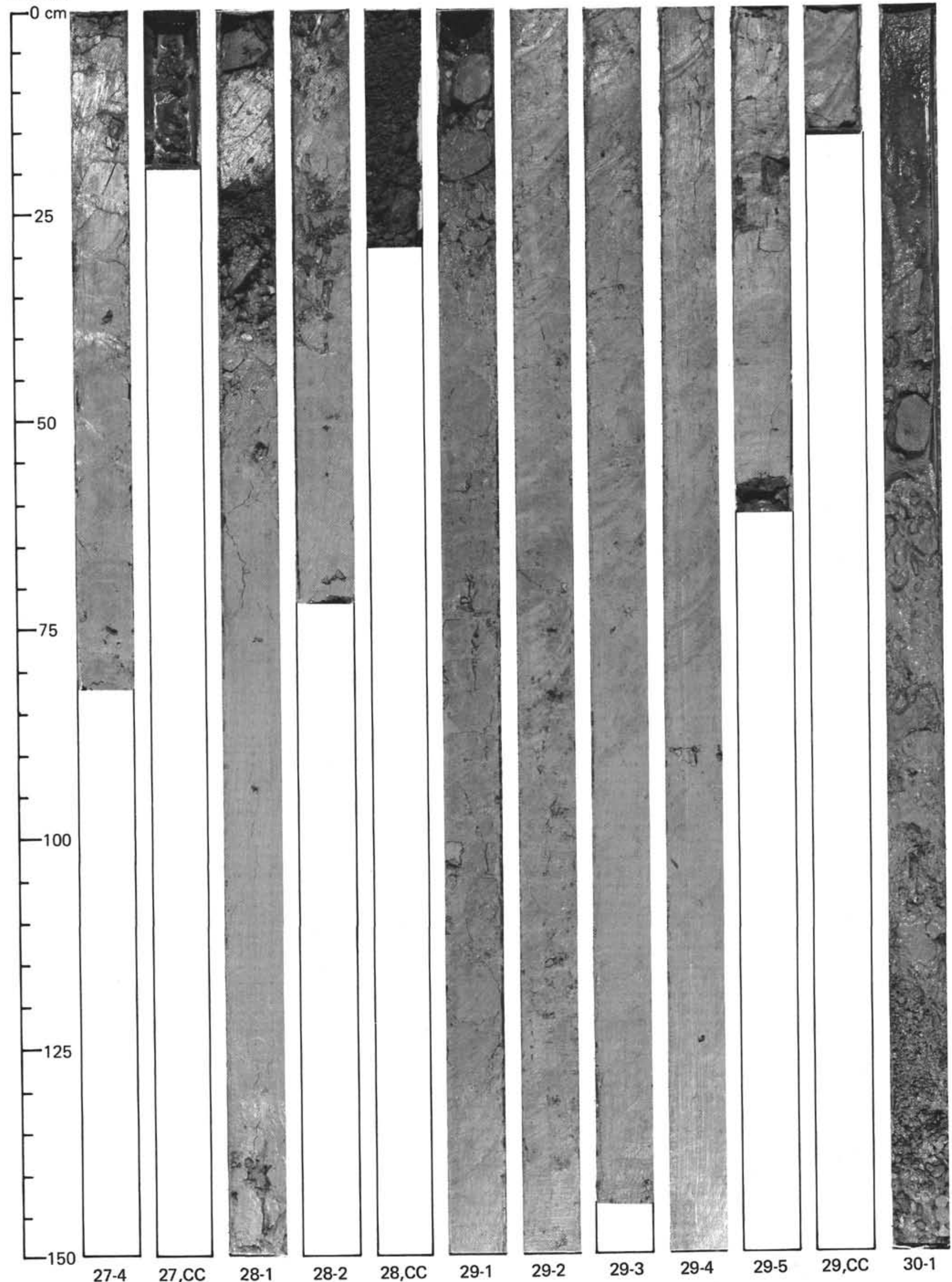


SITE 443

Site 443
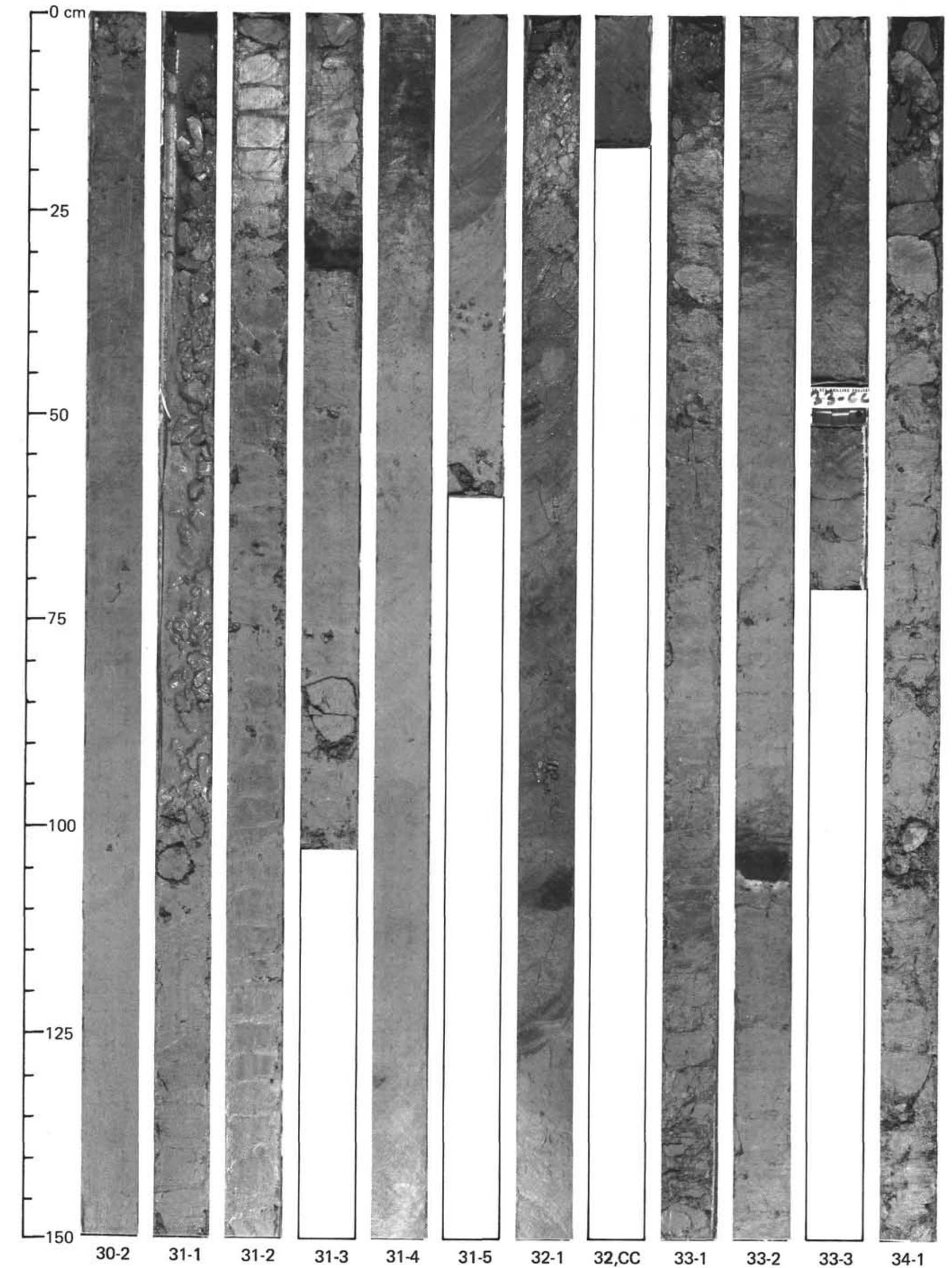

31-4

$31-5$
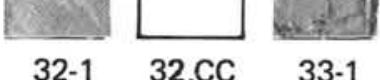

33-1
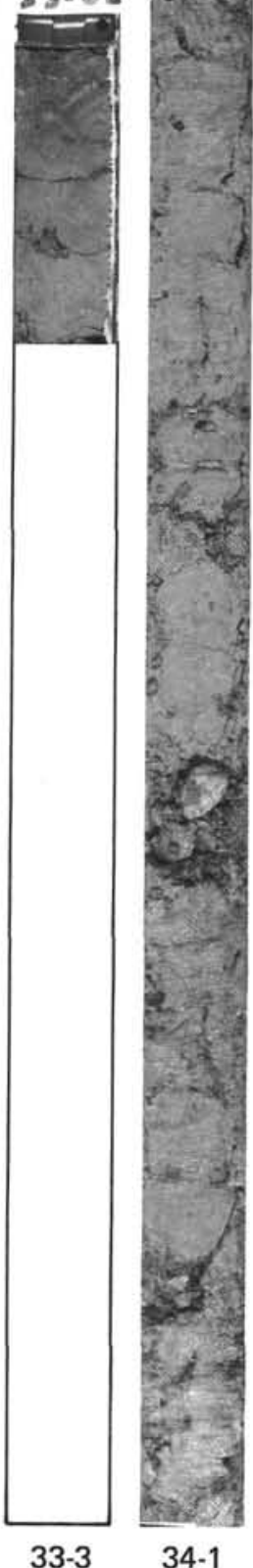
Site 443

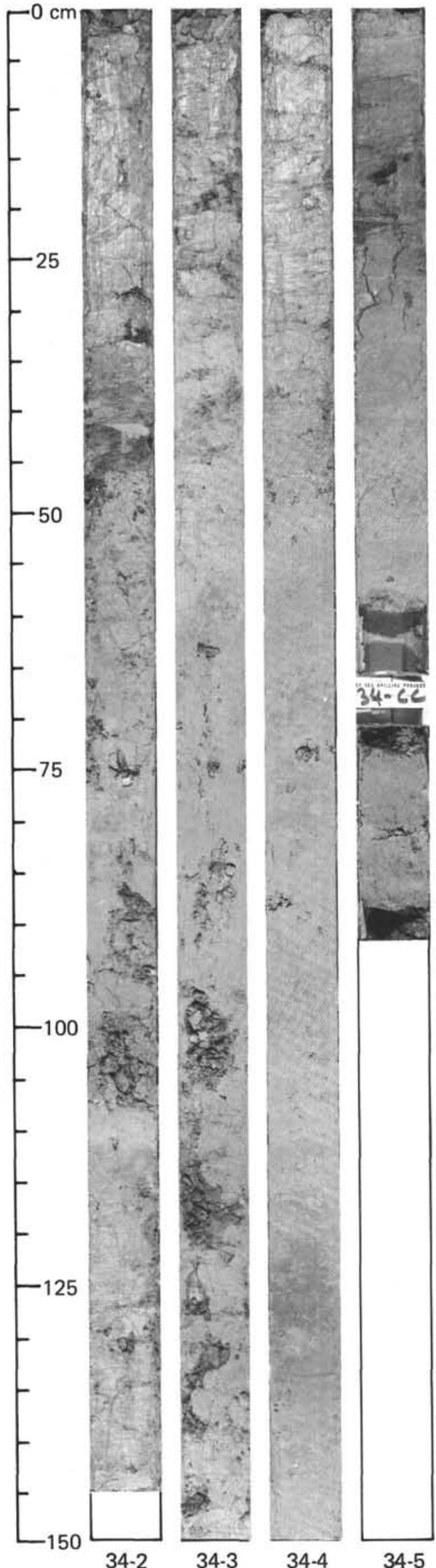

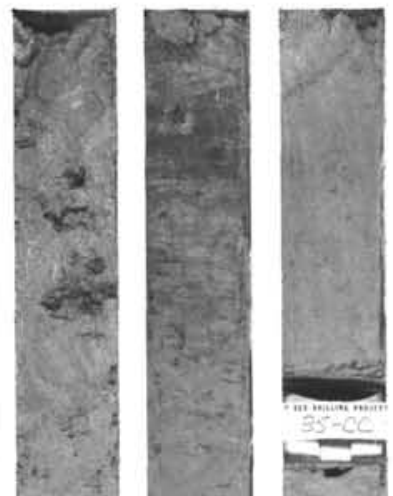
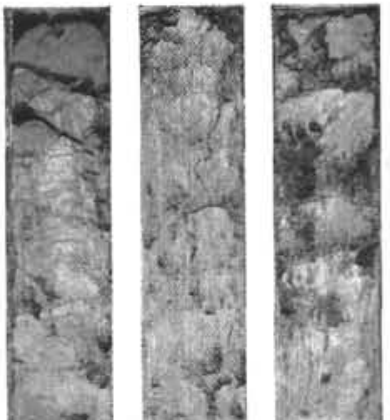

.
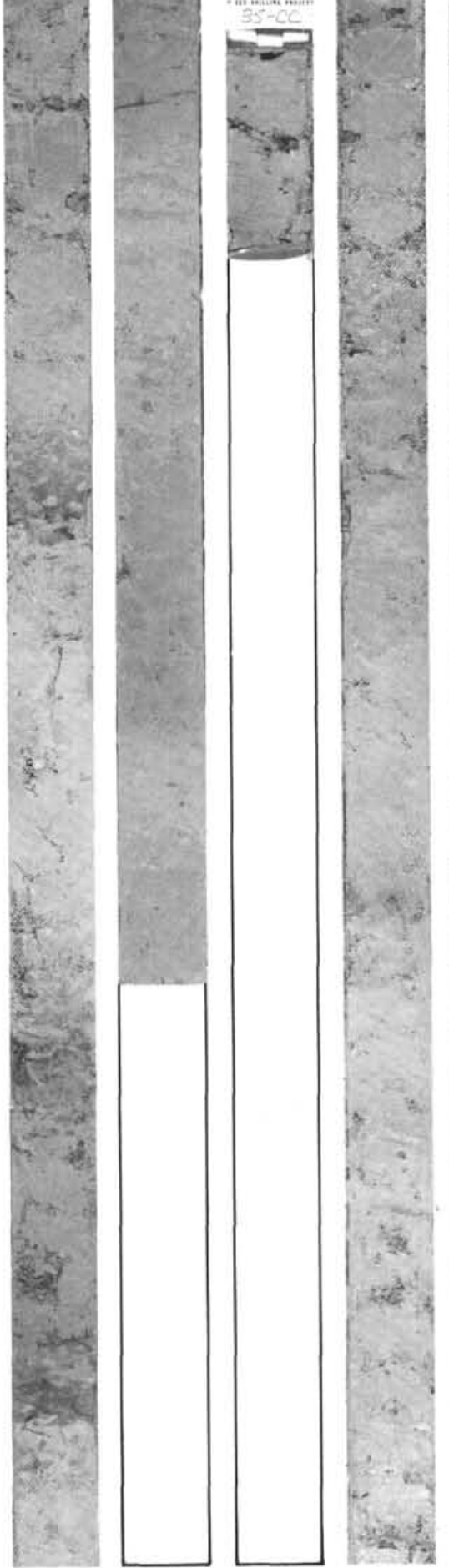

$35-1$

35-2

35-3

36-1
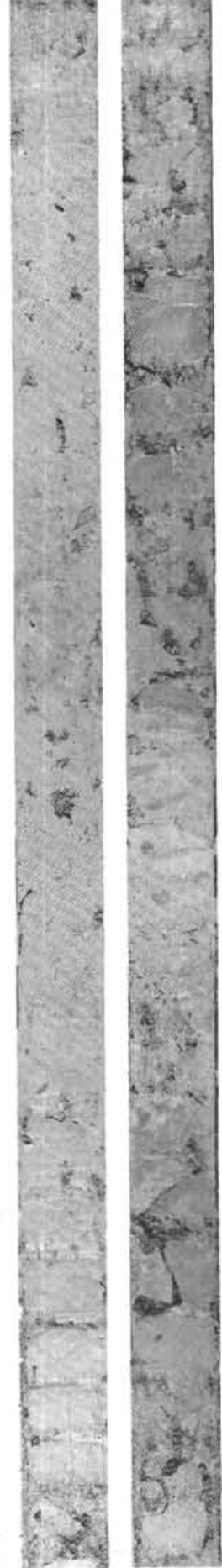

$36-2$

36-3
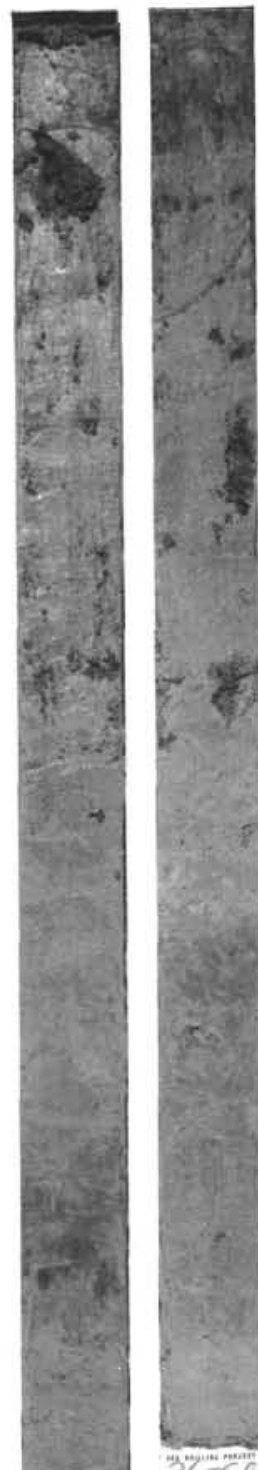

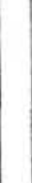
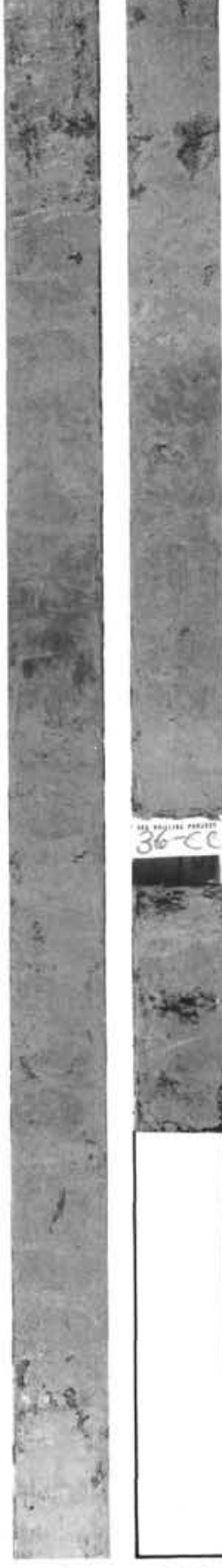

36-4

36-5 
Site 443
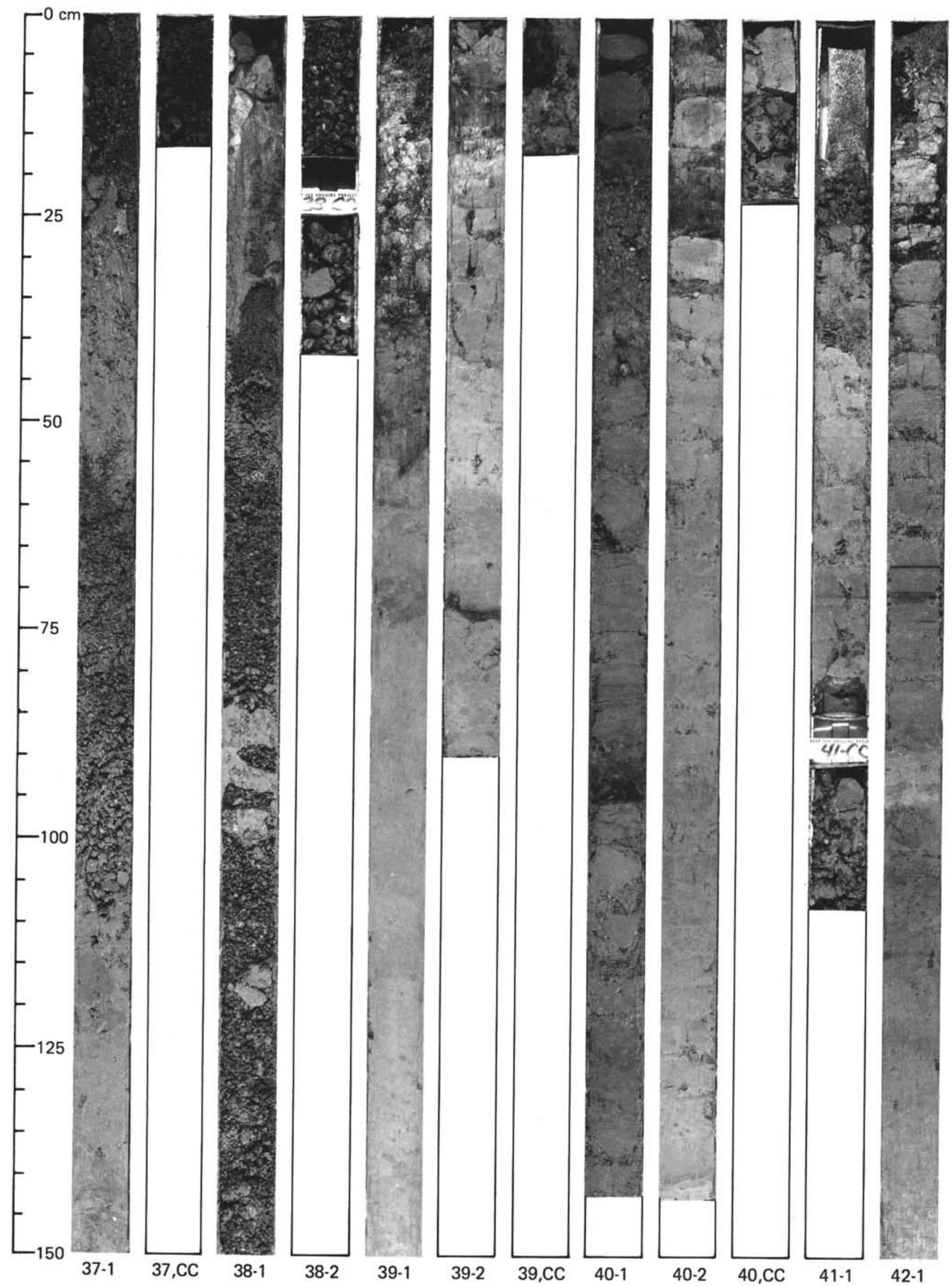

'35:
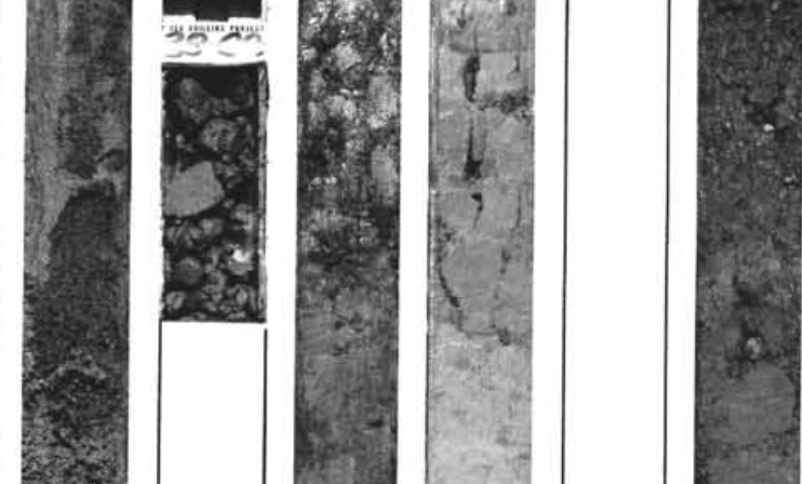

\section{3}
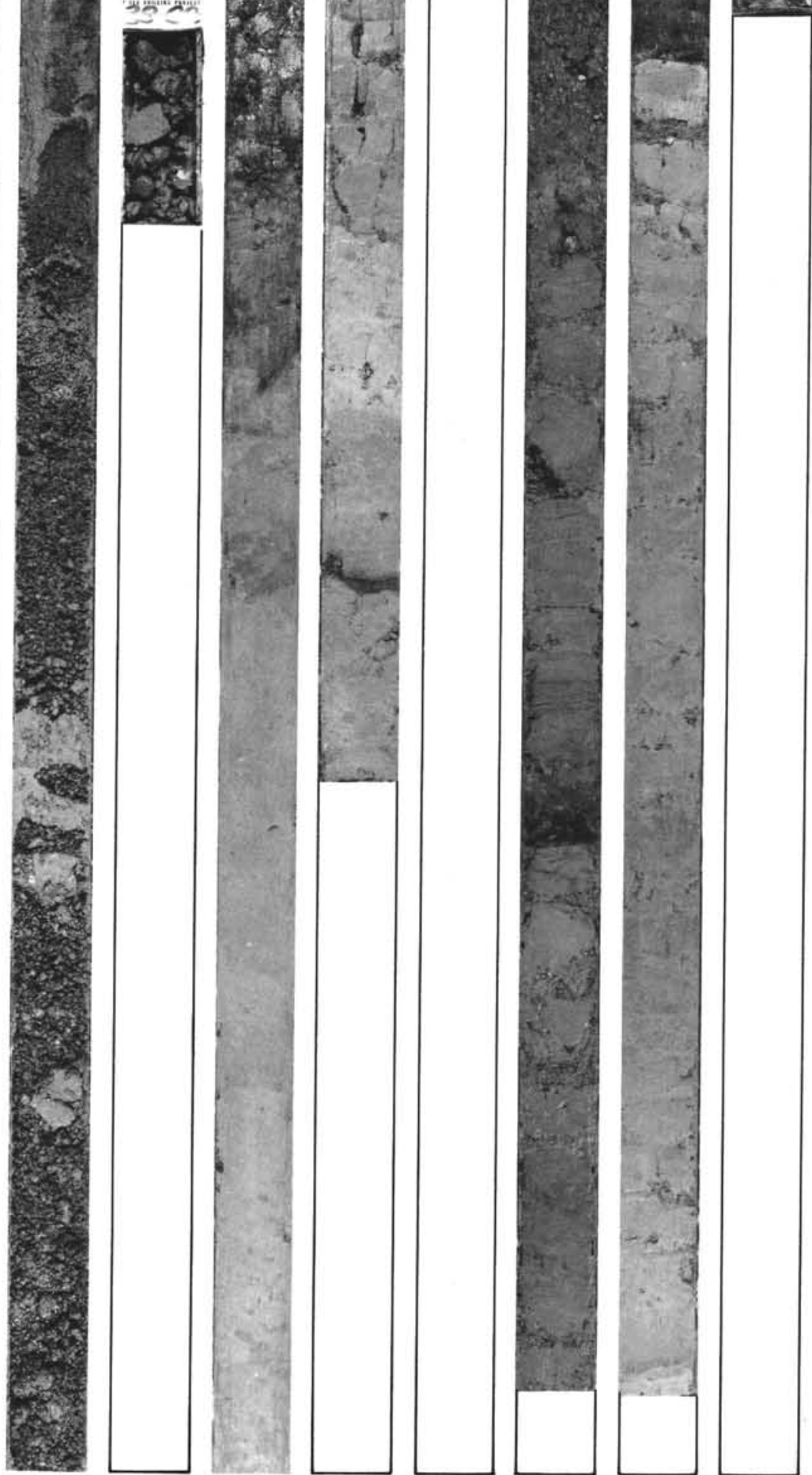

39-1

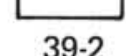

$39, \mathrm{CC}$
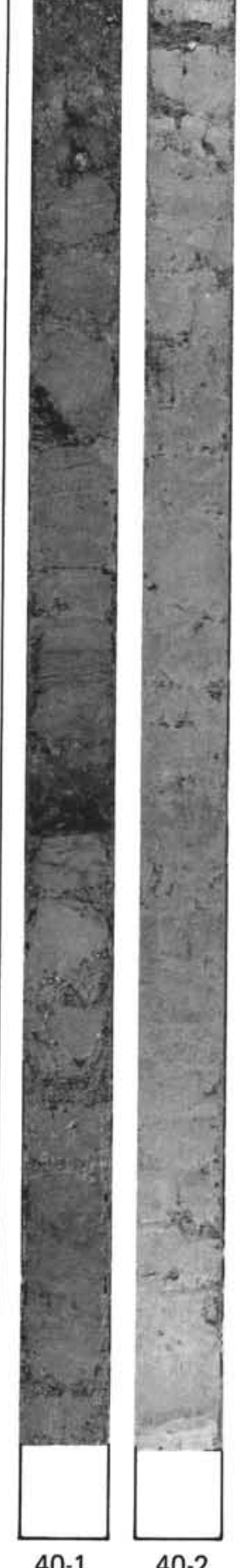

$40-2$ 40,

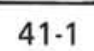

$42-1$ 


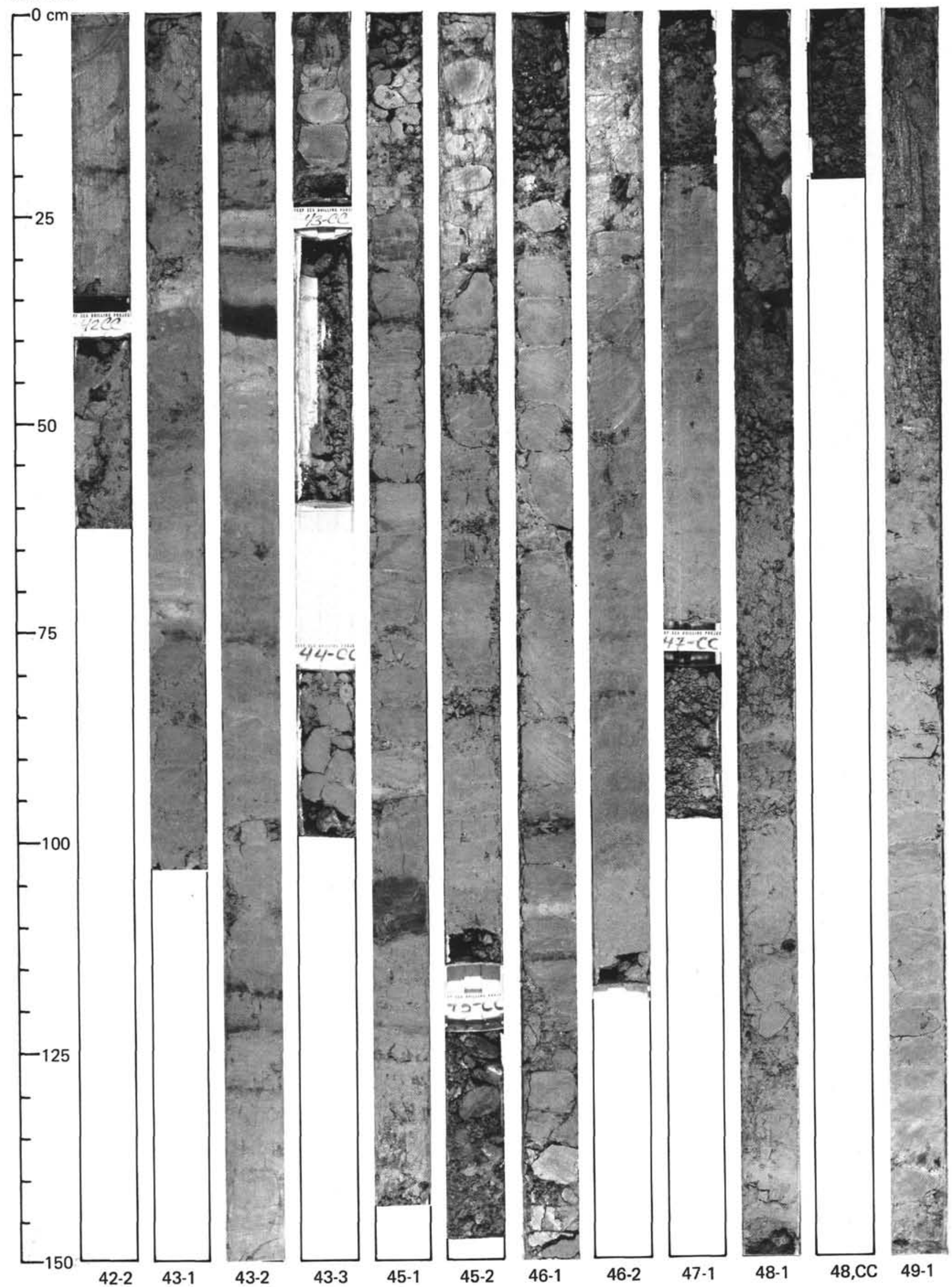


SITE 443

\section{Site 443}

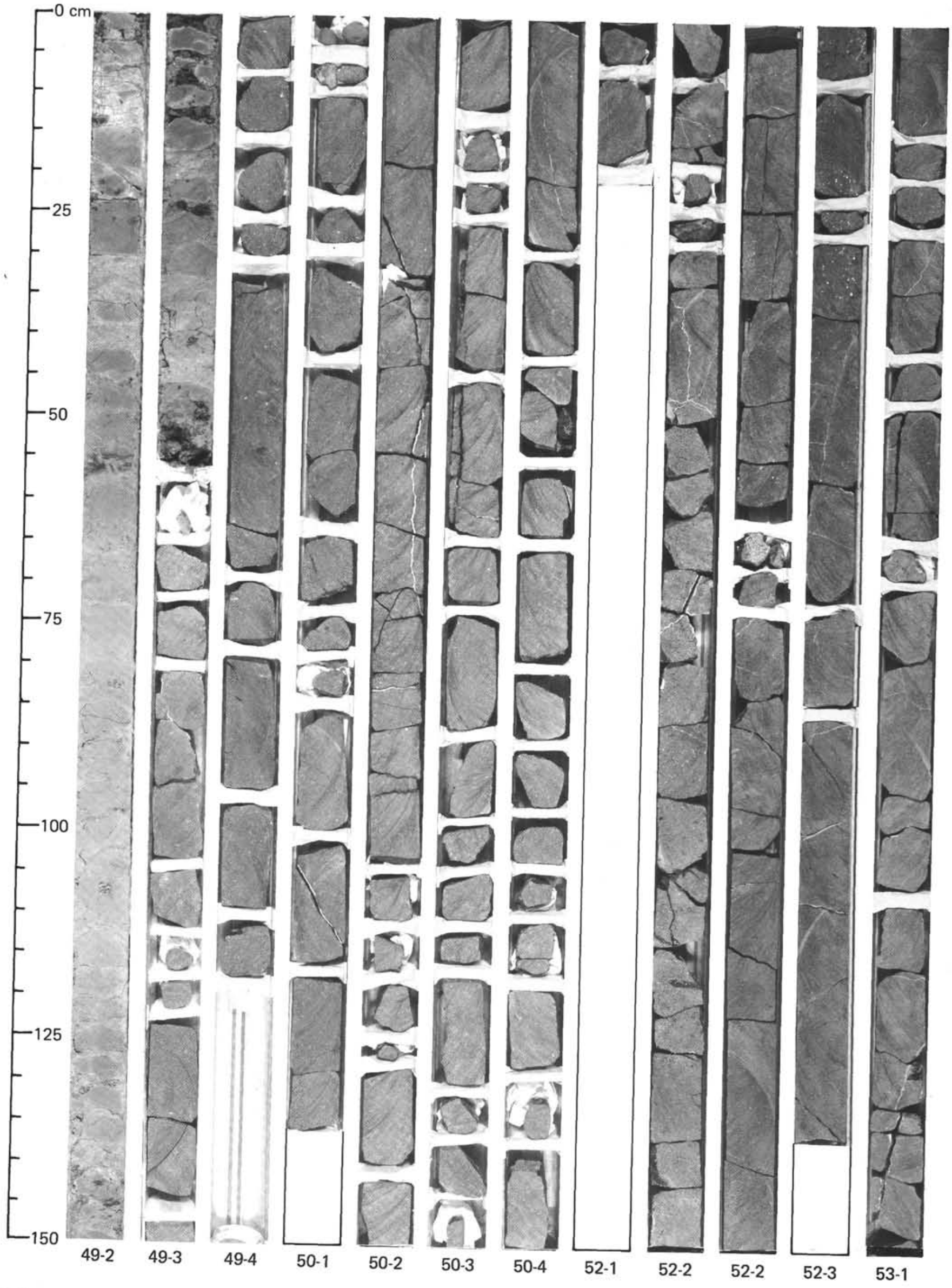


Site 443

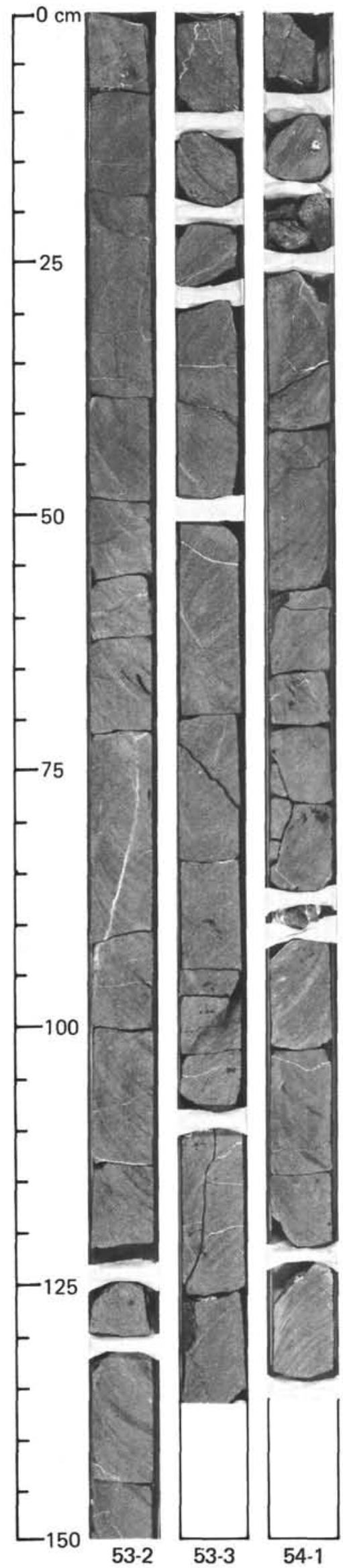

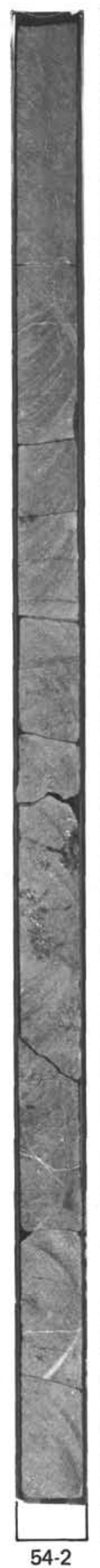
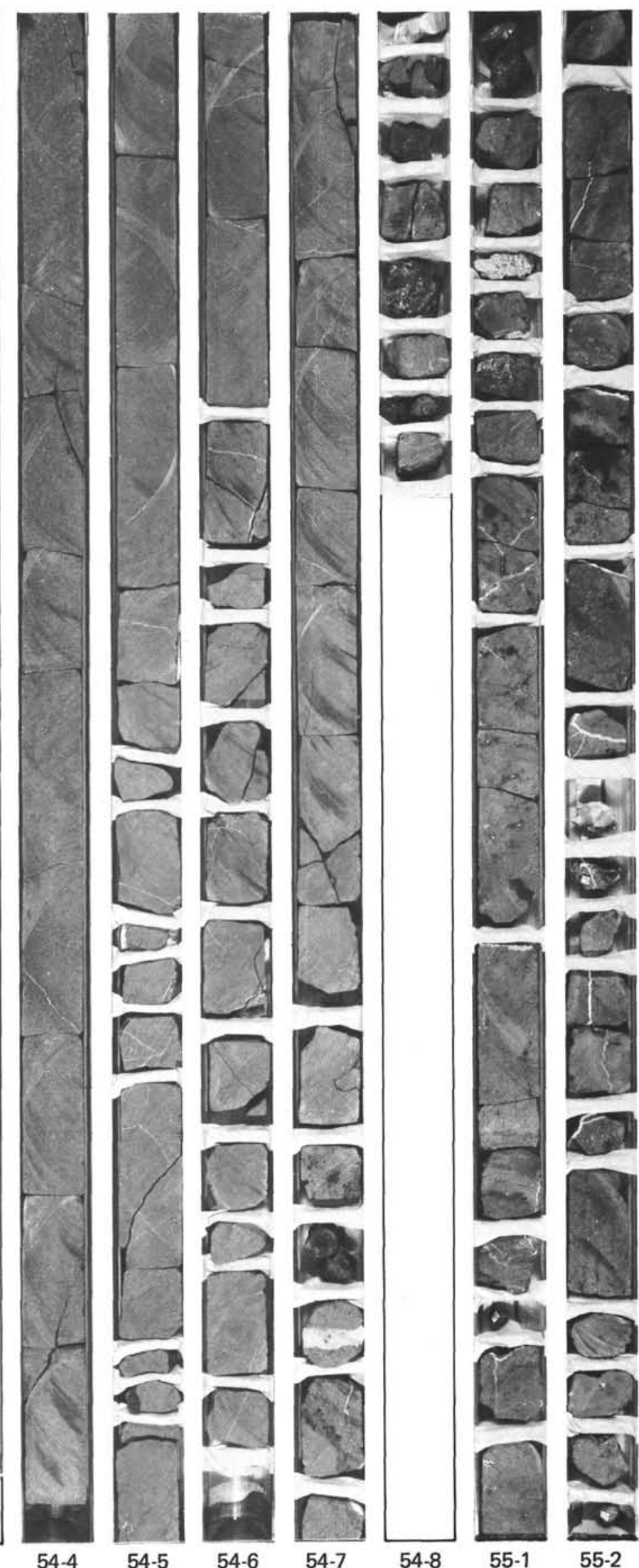

54-5
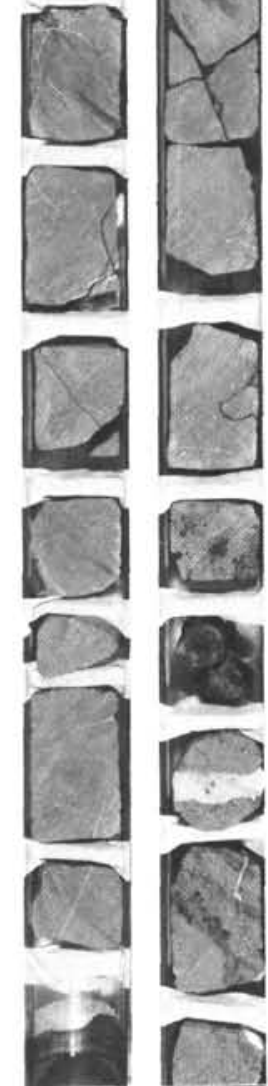

54-6

54-7
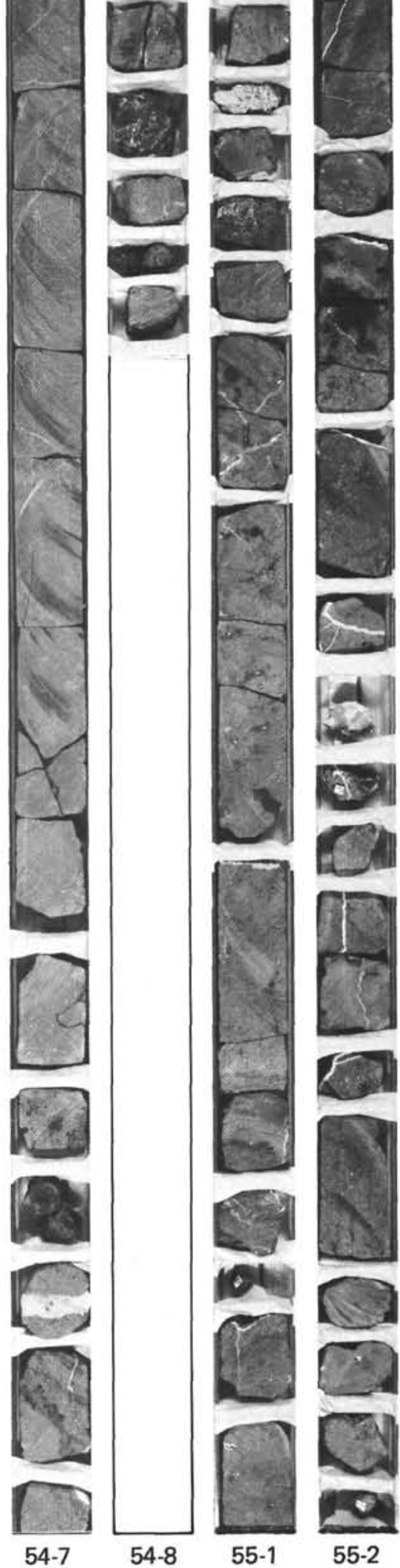

55-1
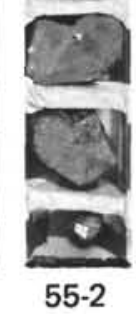


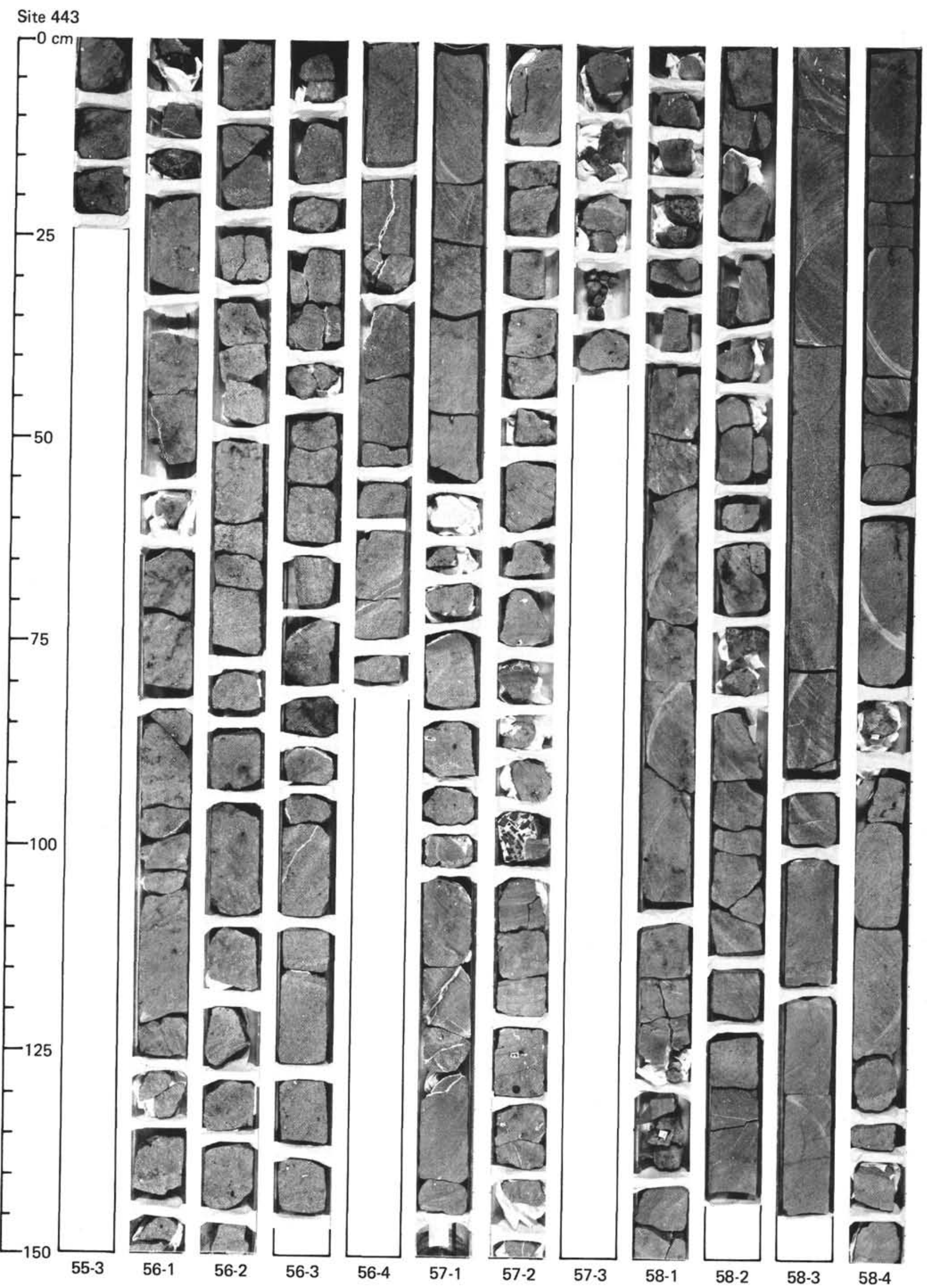


Site 443

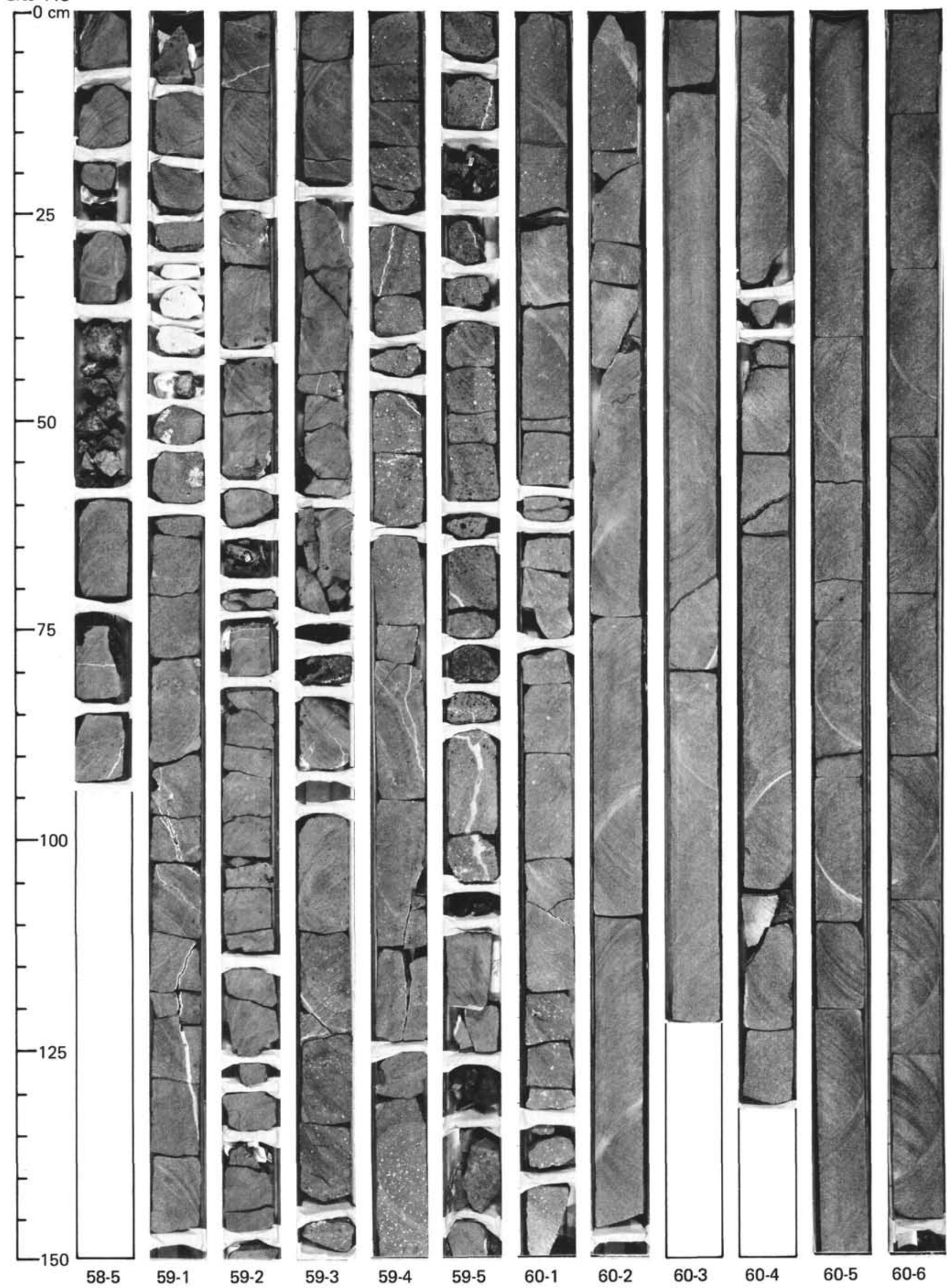


SITE 443

Site 443

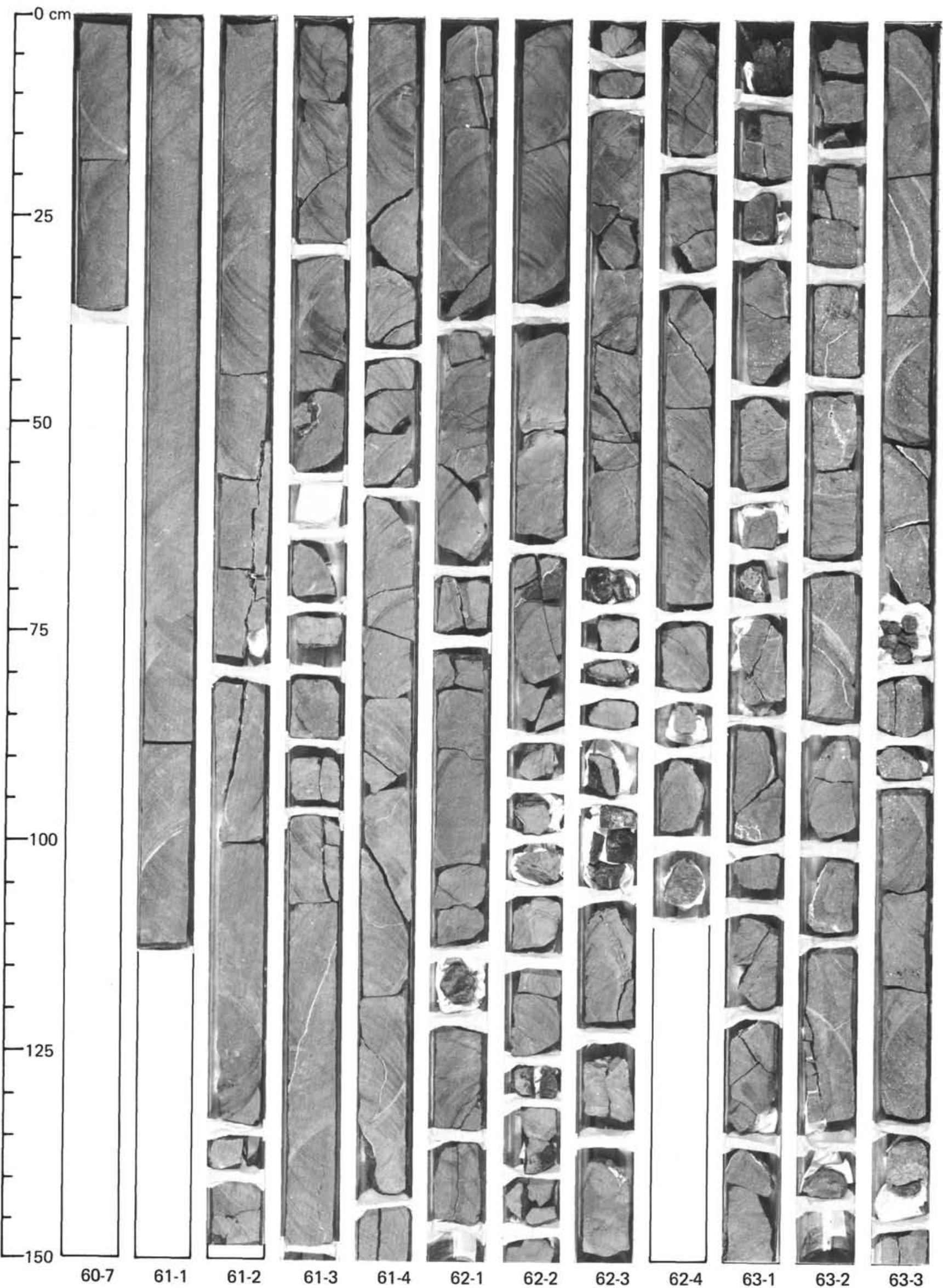




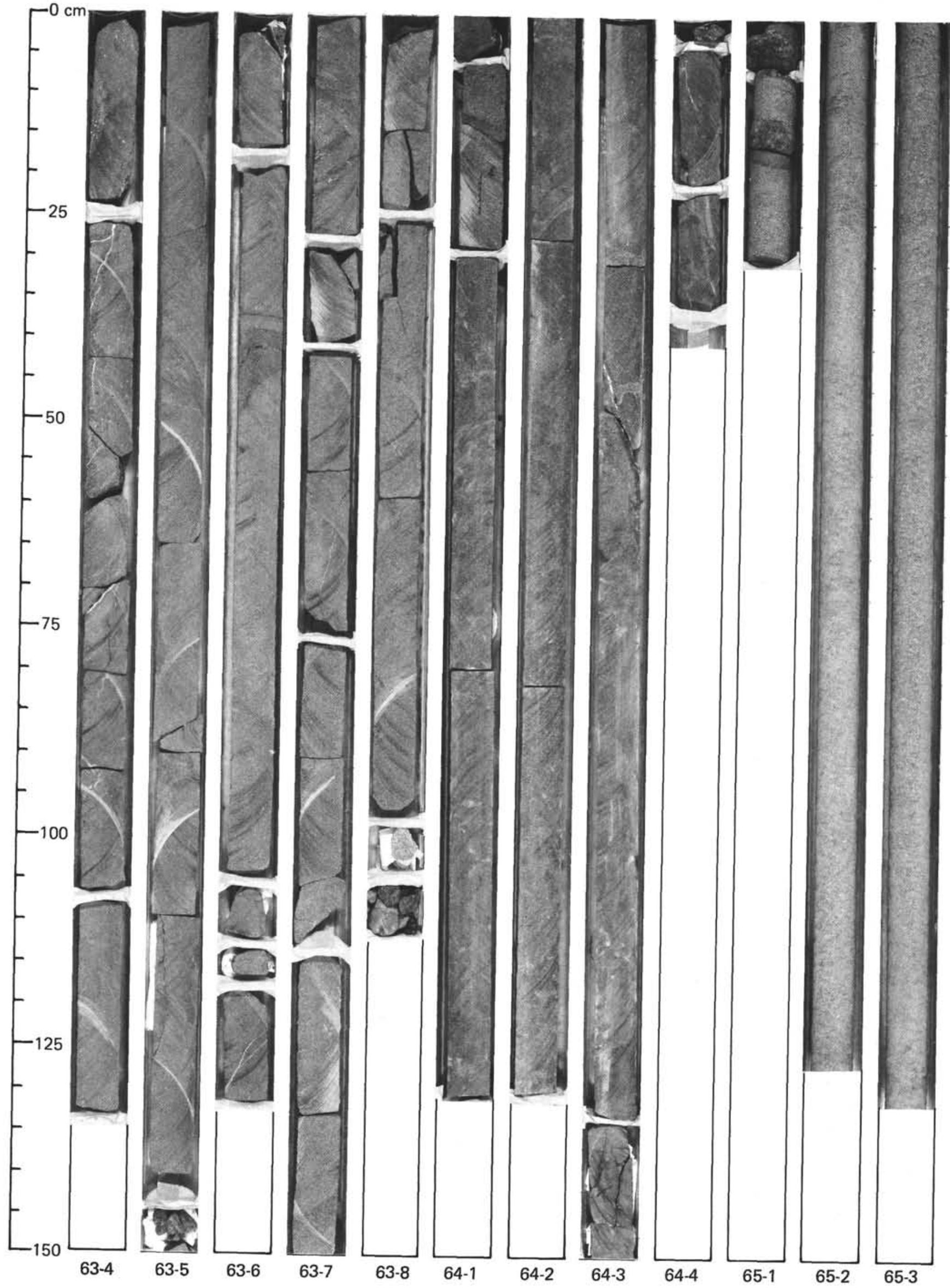


SITE 443

Site 443

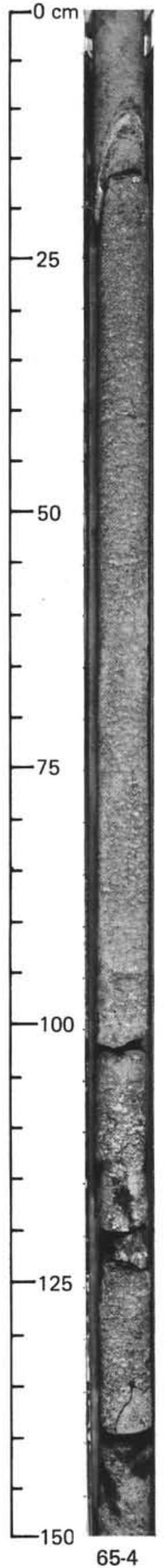

